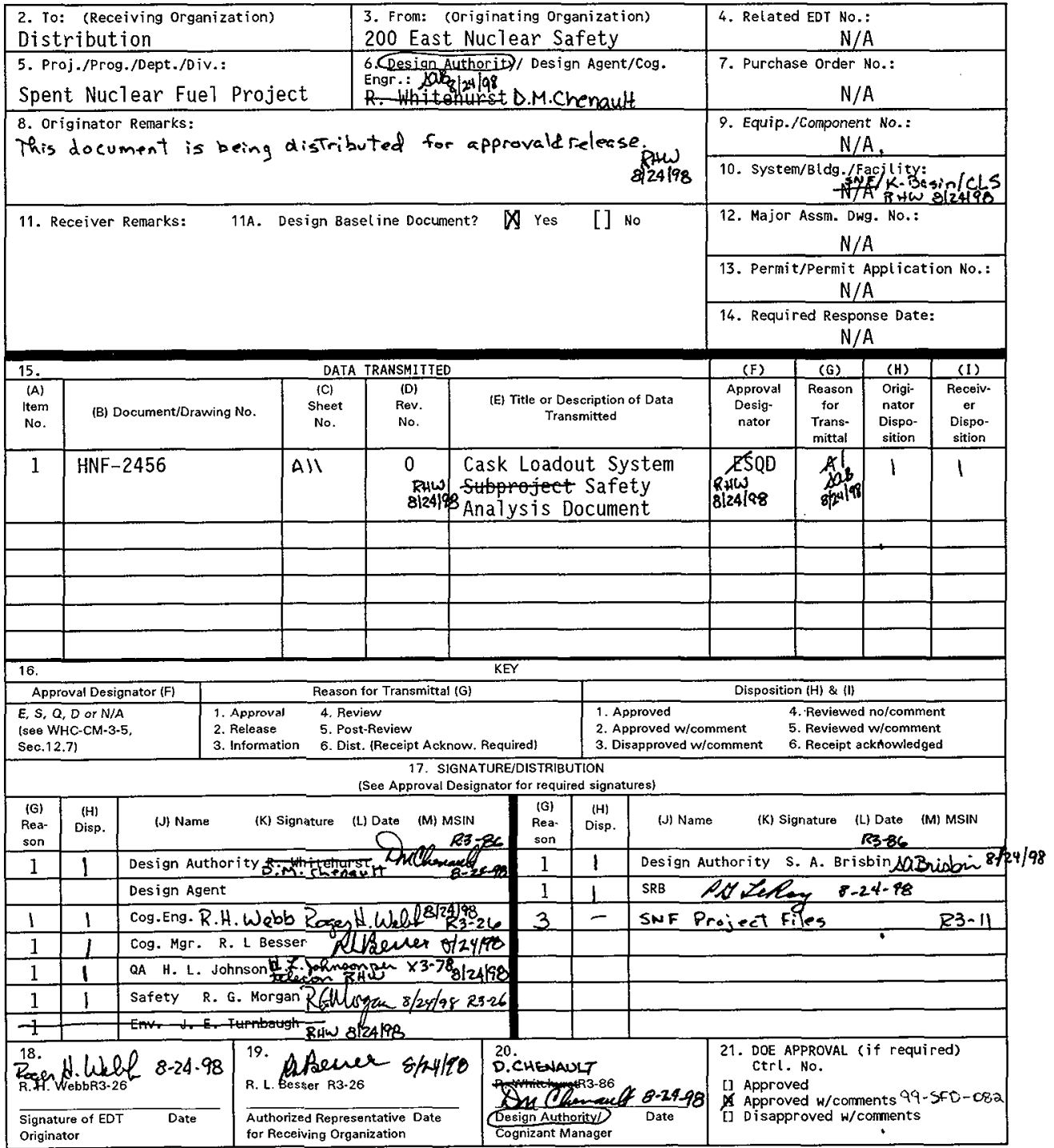

BD-7400-172-2(05/96) GEF097 


\title{
Cask Loadout System Safety Analysis Document
}

\author{
R. H. Webb \\ DE\&S Hanford, Richland, WA 99352 \\ U.S. Department of Energy Contract DE-AC06-96RL13200 \\ EDT: 624289 \\ Org Code: $2 \mathrm{~F} 200$ \\ UC: 920 \\ B\&R Code: EW31354040 \\ Charge Code: 105531/CB80 \\ Total Pages: 245
}

Key Words: safety analysis, hazard, SNF, cask, MCO, loading, drop, overlift, immersion pail, gantry, shuttle

Abstract: This safety analysis document defines hazards associated with the cask loadout system (CLS) equipment installation and operation, documents the safety analyses, and identifies the need of controls to ensure safe operation of the CLS equipment in the K East and $\mathrm{K}$ West Basins. It consists of the level of detail expected in a preliminary safety analysis report. Much of the analysis provided by this document will be included in the K Basins Final Safety Analysis Report to support CLS operations. Major CLS structures, systems, and components include: immersion pail support structure, immersion pail, shuttle, gantry, and support structure.

TRADEMARK DISCLAIMER. Reference herein to any specific commercial product, process, or service by trade name, trademark, manufacturer, or otherwise, does not necessarily constitute or imply its endorsement, recommendation, or favoring by the United States Government or any agency thereof or its contractors or subcontractors.

Printed in the United States of America. To obtain copies of this document, contact: Document Control Services, P.O. Box 950 , Mailstop H6-08, Richland WA 99352, Phone (509) 372-2420; Fax (509) 376-4989.
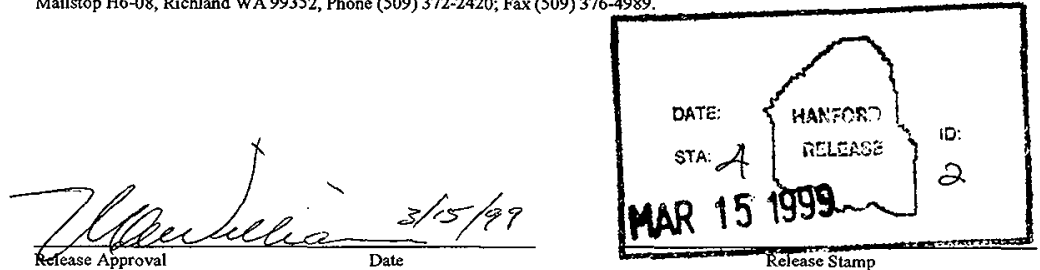

\section{Approved for Public Release}




\section{EXECUTIVE SUMMARY}

This Safety Analysis Document (SAD) defines hazards associated with the cask loadout system (CLS) installation and operation, documents the safety analyses, and identifies the need for controls to ensure safe operation of the CLS equipment in the K East and K West Basins. The CLS safety analysis in this SAD supports revising the $K$ Basin Safety Analysis Report (SAR) ${ }^{1}$

\section{E.1 FACILITY BACKGROUND AND MISSION}

The K Basins are located on the south bank of the Columbia River near the north end of the Hanford Site. The K Basins, built in the early 1950's, are two large basins for underwater storage of irradiated fuel. Except for a few loose pieces, the $\mathrm{K}$ Reactor fuel stored in the basins was shipped for processing to the 200 East Area after the reactors were shut down in the early 1970 's.

The $\mathrm{K}$ Basins presently store a large quantity of $\mathrm{N}$ Reactor spent nuclear fuel (SNF), which has been deteriorating for many years. The SNF Project was formed in 1994 to manage the 2130 metric tons of SNF located in various Hanford Site facilities. The recommended path forward ${ }^{2}$ requires removing the $\mathrm{SNF}$ from the $\mathrm{K}$ Basins and placing it in interim dry storage at a new facility on the Site. The CLS is the equipment necessary to load spent fuel-laden multicanister overpack (MCO) baskets from the Fuel Retrieval Subproject into the Cask-MCO and prepare the Cask-MCO for transport to the Cold Vacuum Drying Facility. The scope of the CLS is defined in the Performance Specification for TN-WHC Cask and Transportation System ${ }^{3}$ and the Performance Specification for SNF K East and K West MCO Loading System. ${ }^{4}$

\section{E.2 FACLITY OVERVIEW}

The K East and K West Basin storage facilities consist of the two fuel storage basins ( $K$ East and K West) and related support facilities. The K Basin SAR ${ }^{1}$ describes the basins; Table E-1 of the SAR ${ }^{1}$ lists the buildings and facilities that support the K Basin fuel storage mission. Inactive buildings are the responsibility of the environmental remediation and restoration contractor.

${ }^{1}$ DESH, 1998, K Basins Safety Analysis Report, WHC-SD-WM-SAR-062, Rev. 3D, DE\&S Hanford, Inc., Richland, Washington.

${ }^{2}$ WHC, 1994, Hanford Spent Nuclear Fuel Project Recommended Path Forward, WHC-EP-0830, Westinghouse Hanford Company, Richland, Washington.

${ }^{3}$ Kee, A. T., 1995, Performance Specification for TN-WHC Cask and Transportation System, WHC-S-0396, Rev. 1, Westinghouse Hanford Company, Richland, Washington.

${ }^{4}$ Brisbin, S. A., 1997, Performance Specification for SNF K East and K West MCO Loading System, WHC-S-0546, DE\&S Hanford, Inc., Richland, Washington. 
Major pieces of the CLS equipment to be added to the $\mathrm{K}$ East and $\mathrm{K}$ West Basins are as follows :

- MCO loading system shuttle

- MCO loading system gantry and support structure

- Immersion pail support structure

- Immersion pail.

The CLS interfaces with the following equipment:

- Fuel Retrieval Subproject MCO basket stiffback grapple

- $\quad \mathrm{MCO}$ and MCO baskets

- Integrated water treatment system

- K Basins transfer bay crane

- $\quad$ Cask transport system.

.

Modifications to the $\mathrm{K}$ East and $\mathrm{K}$ West basins consist of the following:

- $\quad$ Add a windbreak structure to the transfer bay entrance

- Modify mezzanine structure to accommodate the gantry

- Modify the basin grating to accommodate the new CLS equipment and operations

- Add tie-ins to electrical, water, and compressed air systems.

\section{E.3 FACILITY HAZARD CLASSIFICATTON}

The $\mathrm{K}$ Basin is a hazard category 2 facility. The hazard classification is documented in the $K$ - Basin Fuel Encapsulation and Storage Hazard Categorization. ${ }^{5}$ This hazard categorization addresses the potential for release of radioactive and nonradioactive hazardous material located in the $\mathrm{K}$ Basins and their supporting facilities. The analysis covered normal $\mathrm{K}$ Basin fuel storage and handling operations, fuel encapsulation, and canister clean-up and disposal. CLS activities are similar to those covered by the existing hazard category. The accident evaluation section of this SAD demonstrates that installation and operation of the CLS does not change the existing hazard category.

\section{E.4 SAFETY ANALYSIS OVERVIEW}

This safety analysis considers accidental criticality and releases of radioactive and hazardous material under normal and accident conditions. A hazard identification process was completed to systematically and thoroughly review the CLS design, installation, and operation to

SPorten, D. R. 1994, K-Basins Fuel Encapsulation and Storage Hazard Categorization, WHC-SD-SNF-HC-001, Rev. 0, Westinghouse Hanford Company, Richland, Washington. 
HNF-2456, Rev. 0

identify hazards and select accidents and abnormal operations for further analysis. Hazards that showed the highest potential risk or consequences were chosen for accident analysis.

In the accident analysis, the unmitigated onsite and offsite dose consequences for the release of radionuclides were calculated. The unmitigated dose consequences were compared to the risk evaluation guidelines and limits to identify a cost-effective set of safety-class or safetysignificant structures, systems, or components to prevent or mitigate the consequences of a release. Mitigated consequences considering the use of safety-class or safety-significant equipment were compared to the risk evaluation guidelines and limits to ensure optimum mitigation. Only one design basis accident, the MCO basket overlift, has unmitigated consequences that exceed the guidelines and limits. Design features are incorporated into the gantry to prevent the MCO basket overlift. The CLS accident analysis and identification of safety equipment included efforts to identify cost-effective measures for reducing accident consequences well below the guidelines and limits identified in Sellers (1997). ${ }^{6}$ Tables E-1 and E-2 list the accidents and mitigated consequences associated with the CLS operation.

As a result of the hazards analysis, cost-effective preventive and mitigative design features and administrative controls have been identified. Safety-class design structures, systems, or components include the following:

- Immersion pail support structure

- Immersion pail

- $\quad$ MCO loading system gantry and support structure

- $\quad$ MCO loading system shuttle.

All safety-class features are passive. Administrative controls to ensure criticality safety will be implemented through the criticality prevention program required by the $\mathrm{K}$ Basin technical safety requirements.

\section{E.5 ORGANIZATIONS}

As a subcontractor to Fluor Daniel Hanford, Inc., DE\&S Hanford, Inc. (DESH), is responsible for $\mathrm{K}$ Basin operations and the CLS. Transnuclear, Inc., is the design agent and vendor for most of the CLS. NAC International, Inc., is the design agent and vendor for the MCO loading system. Other vendors are as follows:

- Lancs Plastic

- Fluor Daniel Northwest, Inc.

${ }^{6}$ Sellers, E. D., 1997, Contract No. DE-AC06-96RL13200 - Risk Evaluation Guidelines (Regs) to Ensure Inherently Safer Designs, DOE/RL-97-SFD-034, transmitted under letter no. 9754660 to H. J. Hatch, Fluor Daniel Hanford, Inc., dated May 27, 1997, U.S. Department of Energy, Richland Operations Office, Richland, Washington. 
Table E-1. Design Basis Accident Summary.

\begin{tabular}{|c|c|c|c|c|c|c|c|}
\hline \multirow[b]{2}{*}{ Section/accident } & \multirow[b]{2}{*}{$\begin{array}{c}\text { Mitigated } \\
\text { frequency per year }\end{array}$} & \multicolumn{6}{|c|}{ Consequences, rem EDE } \\
\hline & & $100 \mathrm{~m}$ & Guideline & $\begin{array}{c}\text { Near river } \\
\text { bank } \\
(480 \mathrm{~m})\end{array}$ & Guideline & $\begin{array}{c}\text { Hanford Site } \\
\text { boundary } \\
(12,040 \mathrm{~m})\end{array}$ & Limit \\
\hline $\begin{array}{l}\text { 3.4.2.1 Fully Loaded } \\
\text { Cask-MCO Drop into the South } \\
\text { Loadout Pit }\end{array}$ & Unlikely & \multicolumn{6}{|c|}{ No dose anticipated } \\
\hline $\begin{array}{l}\text { 3.4.2.2 Fully Loaded Cask- } \\
\text { MCO Drop Impacts South } \\
\text { Loadout Pit Curb }\end{array}$ & Unlikely & \multicolumn{6}{|c|}{ No dose anticipated } \\
\hline $\begin{array}{l}\text { 3.4.2.3 MCO Basket Overlift } \\
\text { Accident; fuel burns }\end{array}$ & $\begin{array}{c}\text { Beyond extremely } \\
\text { unlikely }\end{array}$ & $1.8 \times 10^{3}$ & 25 & 80 & N/A & 3.8 & 5 \\
\hline $\begin{array}{l}\text { 3.4.2.3 MCO Basket Overlift } \\
\text { Accident; fuel does not burn }\end{array}$ & $\begin{array}{c}\text { Beyond extremely } \\
\text { unlikely }\end{array}$ & 8.7 & 25 & $3.9 \times 10^{-1}$ & N/A & $1.8 \times 10^{-2}$ & 5 \\
\hline $\begin{array}{l}\text { 3.4.2.4 Bounding MCO Basket } \\
\text { Drop }\end{array}$ & $\begin{array}{c}\text { Beyond extremely } \\
\text { unlikely }\end{array}$ & \multicolumn{6}{|c|}{ No dose anticipated } \\
\hline 3.4.2.5 Seismic Event & Unlikely & \multicolumn{6}{|c|}{ No dose anticipated } \\
\hline
\end{tabular}

Notes:

${ }^{1}$ Frequency takes into account safety SSCs.

EDE = Effective dose equivalent.

MCO = Multi-canister overpack.

N/A $=$ Not applicable.

SSC = Systems, structures, and components.

Table E-2. Beyond Design Basis Accident Summary.

\begin{tabular}{|l|c|c|c|c|}
\hline \multicolumn{1}{|c|}{ Section/accident } & Frequency per year & $100 \mathrm{~m}$ & $\begin{array}{c}\text { Near river } \\
\text { bank }(480 \mathrm{~m})\end{array}$ & $\begin{array}{c}\text { Hanford Site } \\
\text { boundary } \\
(12,040 \mathrm{~m})\end{array}$ \\
\cline { 3 - 5 } & & \multicolumn{3}{|c|}{ No radiological release expected } \\
\hline $\begin{array}{l}\text { 3.4.3.1 Uncontrolled Transport Trailer Accident } \\
\text { During Cask-MCO Delivery }\end{array}$ & $\begin{array}{c}\text { Beyond extremely } \\
\text { unlikely }\end{array}$ & $1.8 \times 10^{3}$ & 80 & 3.8 \\
\hline $\begin{array}{l}\text { 3.4.3.2 Seismic Event with Gantry Lift of MCO Fuel } \\
\text { Basket ; fuel burns. }\end{array}$ & $\begin{array}{c}\text { Beyond extremely } \\
\text { unlikely }\end{array}$ & $1.8 \times 0^{\prime}$ & \\
\hline
\end{tabular}

EDE = Effective dose equivalent.

MCO = Multi-canister overpack.

\section{E.6 SAFETY ANALYSIS CONCLUSIONS}

This SAD provides information to support the conclusion that proposed installation and operation of the CLS equipment and related $\mathrm{K}$ Basin facility modifications are in compliance with U.S. Department of Energy (DOE) and other agency rules, regulations, and orders. This SAD 
also confirms that once all safety upgrades have been completed, the CLS equipment can be operated with acceptable risks to the public and onsite personnel.

The accidents analyzed include heavy-load drops, criticality events, transporter impacts to the basin, seismic events, and fuel-burn events. The CLS design took these proposed accidents into consideration to cost-effectively minimize their frequency and consequences. Safety-class design features or administrative controls have been implemented to prevent or mitigate hazards for which the unmitigated consequences exceed the guidelines or limits.

Installation and acceptance testing will not include handling SNF. The scope of installation testing to be authorized is sufficient to ensure that the equipment is installed as specified and that the equipment and controls function.

\section{E.7 SAFETY ANALYSIS DOCUMENT ORGANIZATION}

The structure and content of the SAD parallel the format of DOE-STD-3009-94, Preparation Guide for U.S. Department of Energy Nonreactor Nuclear Facility Safety Analysis Reports, ${ }^{7}$ with the exception of Chapter 6 , "Prevention of Inadvertent Criticality." Chapter 6 is formatted similarly to the criticality safety evaluation report. ${ }^{8}$

\section{E.8 OUTSTANDING ISSUES AND DESIGN STATUS}

CLS design, equipment procurement, and construction and demolition activities in the $\mathrm{K}$ Basin have been approved by the DOE based on Critical Decision 3A. The demolition and construction activities include mezzanine modification, grating modifications, and control station room modifications. A limited activities document ${ }^{9}$ was used to authorize installation of the immersion pail support structure in the K West Basin. Installation and installation testing of the remaining CLS equipment will be approved by the DOE based on information provided for review during the Critical Decision $3 \mathrm{~B}$ process. The information provided for Critical Decision 3B will allow DOE to assess the programmatic risk associated with approving CLS installation and installation testing. This SAD identifies the risk associated with the safety basis developed for the CLS equipment. The SAD must provide sufficient information to allow $\mathrm{DOE}$ to conclude that the risk of approving installation and installation testing of the CLS is acceptable. The SAD also

${ }^{7}$ DOE-STD-3009-94, 1994, Preparation Guide for U.S. Department of Energy Nonreactor Nuclear Facility Safety Analysis Reports, U.S. Department of Energy, Washington, D.C.

${ }^{8}$ Kessler, S. F., 1998, Criticality Safely Evaluation Report for Multi-Canister Overpack Loading and Handling at the K Basins, HNF-2151, Rev. 0, Fluor Daniel Northwest Services, Inc., for Fluor Daniel Hanford, Inc., Richland, Washington.

${ }^{9}$ Sellers, E. D., 1997, Contract No. DE-AC06-96RL13200 - Approval of Critical Decision $3 B$ for the K Basins Focility Upgrades for CaskTransportation Immersion Pail Support Structure, DOE/RL-97-SFD-195, transmitted under letter no. 9758652 to H. J. Hatch, Fluor Daniel Hanford, Inc., U.S. Department of Energy, Richland Operations Office, Richland, Washington. 
must provide sufficient information to assure DOE that the CLS can be operated without undue risk to the health and safety of the public, the workers, and the environment.

Preoperational testing, startup, and operation of the CLS equipment will be authorized based on DOE review and approval of the revised K Basin SAR.

The risks associated with approving the CLS installation and installation testing are summarized as follows:

- Drops of Equipment During Installation. Drops of all CLS equipment during installation have been evaluated to demonstrate that equipment dropped in the basin will not perforate the basin boundary.

- Potential Changes to CLS Safety Analysis. The safety analysis is complete and conservative to minimize the risk of design changes to equipment other than the shuttle. The design changes to the shuttle will be required for it to perform the safety functions identified in this document.

- Potential Changes to CLS Design. Most of the CLS equipment was procured general service. USQ-97-0175, Basin Perforation Issue, was subsequently identified and closed by the $\mathrm{K}$ Basins safety evaluation report dated October 24, 1997. As a result, a requirement prohibiting perforation of the basin boundary was added to the $K$ Basins Safety Analysis Report. ${ }^{1}$ The CLS safety analysis designates the immersion pail support structure, immersion pail, shuttle, and gantry as safety class to support the non-perforation requirement. As a result, the immersion pail support structure, immersion pail, and gantry will undergo a safety upgrade process. Preliminary evaluations of this equipment provide a high degree of confidence that the as-designed and as-fabricated equipment can be successfully upgraded tofulfill the required safety-class functions.

The shuttle currently is undergoing a design modification that will incorporate features that address the energy absorption safety functions required during a seismically induced MCO basket drop. Once the shuttle design modification is complete, it will meet all the safety-class design requirements found in DOE Order $6430.1 \mathrm{~A}^{10}$ to support the safety functions identified in this document.

The safety upgrades will be performed before installation so that the safety features can be tracked through installation. Once the shuttle design is upgraded, the design change control process provides reasonable assurance that all changes will be adequately reviewed to ensure that the change meets the safety analysis requirements.

${ }^{10}$ DOE Order 6430.1A, General Design Criteria, U.S. Department of Energy, Washington, D.C. 
- Immersion Pail Support Structure Installation. The K East Basin south loadout pit has a mound of grout on its floor that will interfere with the installation of the K East immersion pail support structure. Preliminary scoping activities to address this issue have begun. A detailed plan to address the issues is to be generated in fiscal year 1999.

- Draft Documents. Table E-3 lists the draft documents used to prepare this SAD. Their overall risk of affecting this SAD is low.

Table E-3. Risk of Draft Documents in this SAD

\begin{tabular}{|c|c|c|}
\hline Document & Number & Risk \\
\hline $\begin{array}{l}\text { Safety Analysis Report for } \\
\text { Packaging (Onsite) Multi- } \\
\text { canister Overpack }\end{array}$ & $\begin{array}{l}\text { HNF-SD-TP-SARP-017, } \\
\text { Rev. } 1 \text { draft }\end{array}$ & $\begin{array}{l}\text { LOW } \\
\text { This document has been submitted to the DOE and is } \\
\text { finishing its review-approval process. No significant } \\
\text { technical issues have been identified. }\end{array}$ \\
\hline $\begin{array}{l}\text { Multi-canister Overpack } \\
\text { Topical }\end{array}$ & $\begin{array}{l}\text { HNF-SD-SNF-SARR-005, } \\
\text { Rev. } 1 \text { draft }\end{array}$ & $\begin{array}{l}\text { LOW } \\
\text { This document has not been formally released. There } \\
\text { is a slight risk that some of the reference data in the } \\
\text { draft report may change. The MCO safety evaluation } \\
\text { may be included in stand-alone documents instead of } \\
\text { the topical itself. }\end{array}$ \\
\hline $\begin{array}{l}\text { Fire Hazard Analysis for the } \\
\text { K-Basins Facilities at the } \\
100 \mathrm{~K} \text { Area }\end{array}$ & $\begin{array}{l}\text { HNF-SD-SNF-FHA-001, } \\
\text { Rev. } 1 \text { draft }\end{array}$ & $\begin{array}{l}\text { LOW } \\
\text { This document is going through the review-approval } \\
\text { process and is expected to be released in September } \\
\text { 1998. The FHA does not identify any major issues } \\
\text { with this SAD. }\end{array}$ \\
\hline $\begin{array}{l}\text { Assessment for Potential } \\
\text { Rapid Oxidation of } \\
\text { Submerged NReactor Fuel }\end{array}$ & HNF-2786, Rev. 0 draft & $\begin{array}{l}\text { LOW } \\
\text { All technical issues with this document have been } \\
\text { resolved; it is undergoing the approval process. This } \\
\text { document supports the HAZOPS assumption that } \\
\text { SNF, once loaded in the MCO with the shield plug } \\
\text { installed, will not spontaneously ignite under water. } \\
\text { (If it were to ignite, it could create an over- } \\
\text { pressurization hazard). }\end{array}$ \\
\hline $\begin{array}{l}\text { Mulit-canister Overpack } \\
\text { Loading System Anchorage } \\
\text { Analysis for } 105 \mathrm{KW} \text { and } \\
105 \mathrm{KE}\end{array}$ & $\begin{array}{l}\text { HNF-2052, } \\
\text { Rev. } 0 \text { draft }\end{array}$ & $\begin{array}{l}\text { LOW } \\
\text { This document is undergoing extreme modification to } \\
\text { support the shuttle modification design efforts. This } \\
\text { document will substantiate the safety requirements } \\
\text { identified by this SAD. }\end{array}$ \\
\hline \multicolumn{3}{|c|}{$\begin{array}{l}\text { DOE = U.S. Department of Energy. } \\
\text { FHA = Fire hazards analysis. } \\
\text { HAZOPS = Hazards and operability study } \\
\text { MCO = Multi-canister overpack } \\
\text { SAD = Safety analysis document. } \\
\text { SNF = Spent nuclear fuel. }\end{array}$} \\
\hline
\end{tabular}


HNF-2456, Rev. 0

Table E-4 shows the status of the CLS design and procurement as of August 6, 1998. This table demonstrates that the risk of significant design changes is small because the design is substantially complete.

Except for the shuttle modification efforts, the design calculations for structural and drop analyses have been completed and are in the review and approval cycle. No problems are expected, so the risk of change is small. A design modification to the shuttle is required to incorporate an energy-absorption feature; however, this document identifies the critical parameters to support the design change and its safety function of absorbing energy in an MCO basket drop accident. CLS interfaces with other subprojects and facilities are defined and controlled. No changes are expected to these interfaces that will result in changes to the CLS design.

The following recently closed $\mathrm{K}$ Basin unreviewed safety question (USQ) was reviewed and has no impact on CLS equipment installation, installation testing, or expected operations.

Basin Perforation Issue (USQ K-97-0175). The heavy-load drops discussed in this SAD do not result in penetration of the basin floor. The calculations of heavy-load drops on the basin floor will be submitted for approval by the DOE in accordance with the DOE safety evaluation report requirements. The U.S. Department of Energy, Richland Operations Office K Basins safety evaluation report dated October 24, 1997, closes this USQ. ${ }^{11}$

The following recent $\mathrm{K}$ Basin USQ was reviewed and determined to be an outstanding issue.

Basin Drain Valve Issue (USQ K-97-0265). CLS equipment and operations are installed and performed in close proximity to the south loadout pit drain valve. Closure of this USQ will address this issue. All drop analysis in the vicinity of the south loadout pit drain valve show that drop forces onto the south loadout pit concrete do not transmit to the drain valve.

The other outstanding issues are as follows:

- Safety-class upgrade of the immersion pail support structure

- Safety-class upgrade of the immersion pail

- Safety-class upgrade of the gantry

- Shuttle design modification and safety-class upgrade of already-procured shuttle.

${ }^{11}$ Wagoner, J. D., 1997, K Basins Safety Evaluation Report, Rev. 0, transmitted by letter 98-SFD-063, U.S. Department of Energy, Richland Operations Office, Richland, Washington. 
HNF-2456, Rev. 0

Table E-4. CLS Design and Procurement Status.

\begin{tabular}{|l|l|l|}
\hline \multicolumn{1}{|c|}{ CLS equipment } & \multicolumn{1}{|c|}{ Design status } & \multicolumn{1}{c|}{ Procurement status } \\
\hline Shuttle* & Completed, issued & $\begin{array}{l}\text { K West procured and on site; } \\
\text { K East in fabrication }\end{array}$ \\
\hline Gantry support structure & Completed, in approval process & To be procured \\
\hline Gantry & Completed, issued & Procured, in fabrication \\
\hline $\begin{array}{l}\text { Immersion pail support } \\
\text { structure }\end{array}$ & Completed, issued & $\begin{array}{l}\text { Procured, K West installed, } \\
\text { K East on site }\end{array}$ \\
\hline Immersion pail & Completed, issued & Both are procured and on site \\
\hline Windbreak structure & Completed, issued & Procured, in fabrication \\
\hline Transfer bay crane & Completed, issued & $\begin{array}{l}\text { K West installed, K East } \\
\text { scheduled for fiscal year 1999 }\end{array}$ \\
\hline Worker platform & Completed, in approval process & To be procured \\
\hline
\end{tabular}

*Note: Will have to include design modification for shuttle energy absorption, which prevents a basket drop accident. The shuttle design modification currently is in the definitive design stage.

The design and safety analysis are sufficiently complete and conservative that significant changes are unlikely. The programmatic risk of approving CLS installation and installation testing, which will be accomplished in accordance with the $\mathrm{K}$ Basin procedural requirements, is judged to be acceptable. 
HNF-2456, Rev. 0

This page intentionally left blank. 


\section{CONTENTS}

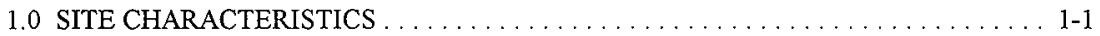

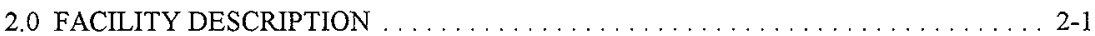

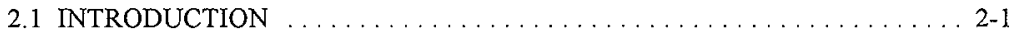

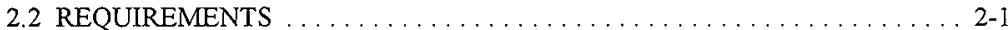

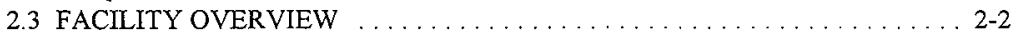

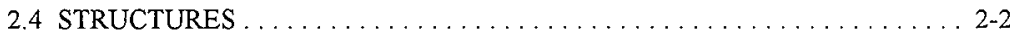

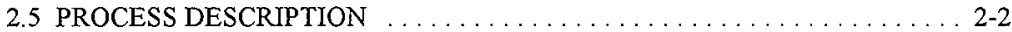

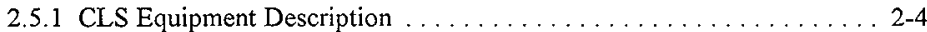

2.5.2 CLS Operation Description . . . . . . . . . . . . . . . 2-8

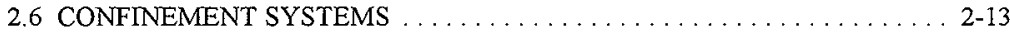

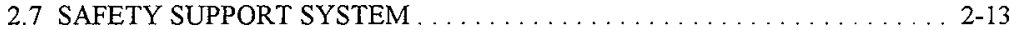

2.8 UTMLITY DISTRIBUTION SYSTEM $\ldots \ldots \ldots \ldots \ldots \ldots \ldots \ldots \ldots \ldots \ldots \ldots$

2.9 AUXILIARY SYSTEMS AND SUPPORT FACILITIES . . . . . . . . . 2-13

2.10 REFERENCES . . . . . . . . . . . . . . . . . . . 2-13

3.0 HAZARD AND ACCIDENT ANALYSES . . . . . . . . . . . . . . . . 3-1

3.1 INTRODUCTION ................................ 3-1

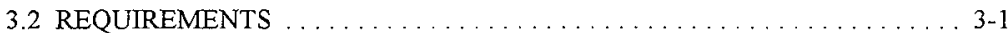

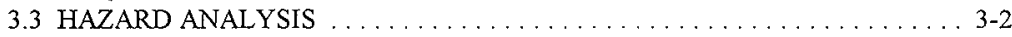

3.3 .1 Method . . . . . . . . . . . . . . . . . . . . . . . $3-4$

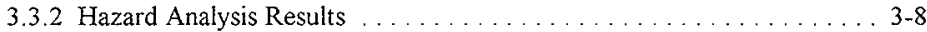

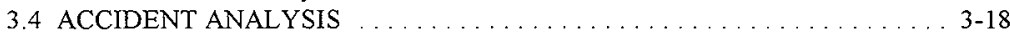

3.4 .1 Analysis Method . . . . . . . . . . . . . . . . . . . . . . 3-19

3.4 .2 Design Basis Accidents . . . . . . . . . . . . . . . . . . . . 3-20

3.4.3 Beyond Design Basis Accidents . . . . . . . . . . . . . . 3-31

3.5 REFERENCES . . . . . . . . . . . . . . . . . . . . . . . 3-34

4.0 SAFETY STRUCTURES, SYSTEMS, AND COMPONENTS . . . . . . . . . . . . 4-1

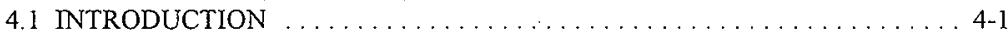

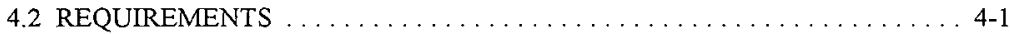

4.3 SAFETY-CLASS STRUCTURES, SYSTEMS, AND COMPONENTS . . . . 4 4-1

4.3.1 Immersion Pail Support Structure . . . . . . . . . . . . . 4-2

4.3 .2 Immersion Pail . . . . . . . . . . . . . . . . . . . . 4-5

4.3.3 Gantry and Support Structure ................... 4-6

4.3.4 MCO Loading System Shuttle ................. . 4-9

4.4 SAFETY-SIGNIFICANT STRUCTURES, SYSTEMS, AND

COMPONENTS . . . . . . . . . . . . . . . . . . . . . . . . . 4-11

4.5 REFERENCES . . . . . . . . . . . . . . . . . . . . . 4-11

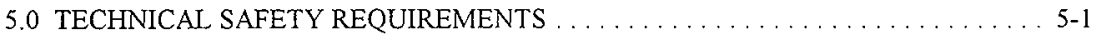


6.0 PREVENTION OF INADVERTENT CRITICALITY . . . . . . . . . . . . . . 6-1

6.1 OVERVIEW OF MCO HANDLING AND LOADING

CRITICALITY ANALYSIS . . . . . . . . . . . . . . . . . . . . 6-1

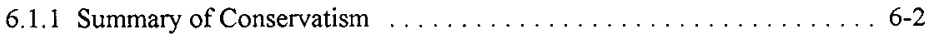

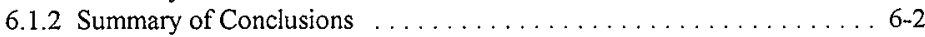

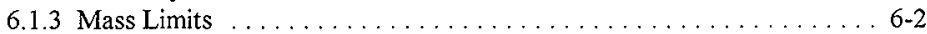

6.1 .4 Summary of Controls ....................... 6-2

6.1.5 Dimensions Requiring Quality Control Verification ..........6-3

6.2 REFERENCES . . . . . . . . . . . . . . . . . . . . . . . 6-3

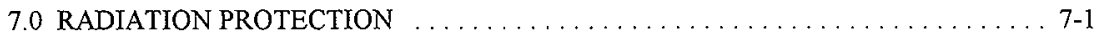

8.0 HAZARDOUS MATERIAL PROTECTION $\ldots \ldots \ldots \ldots \ldots \ldots \ldots \ldots \ldots$ 8-1

9.0 RADIOACTIVE AND HAZARDOUS WASTE MANAGEMENT $\ldots \ldots \ldots \ldots \ldots$ 9-1

10.0 INITIAL TESTING, IN-SERVICE SURVEILLANCE, AND MAINTENANCE $\ldots . \quad$ 10-1

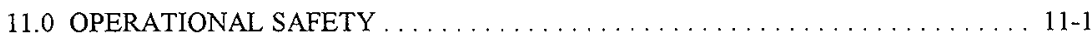

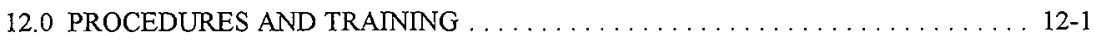

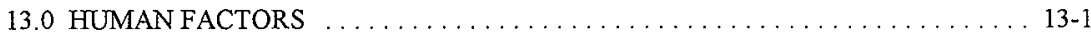

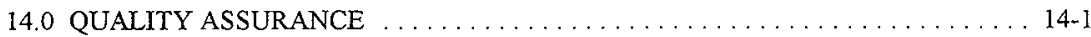

15.0 EMERGENCY PREPAREDNESS PROGRAM ..............

16.0 PROVISIONS FOR DECONTAMINATION

AND DECOMMISSIONING $\ldots \ldots \ldots \ldots \ldots \ldots \ldots \ldots \ldots \ldots \ldots \ldots \ldots \ldots$

17.0 MANAGEMENT, ORGANIZATION, AND INSTITUTIONAL SAFETY PROVISIONS 


\section{LIST OF FIGURES}

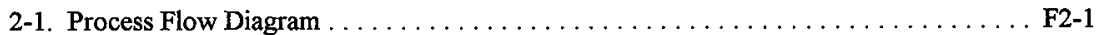

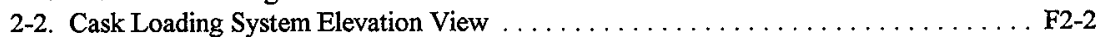

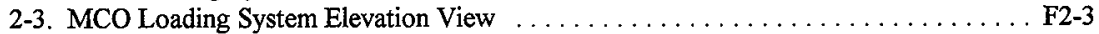

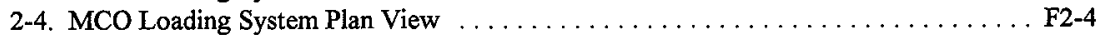



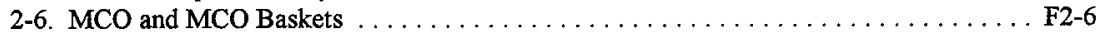

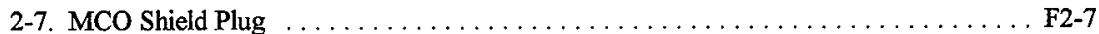

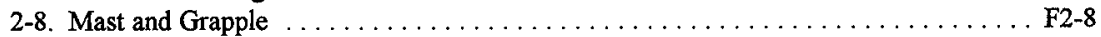

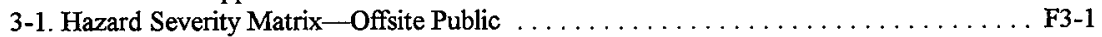

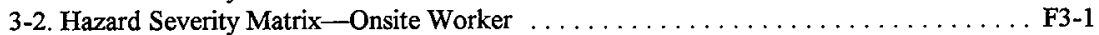

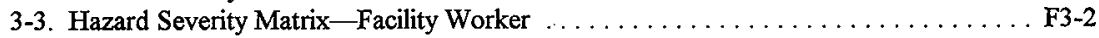

3-4. Elevation View of South Loadout Pit and Wall Showing Damage from

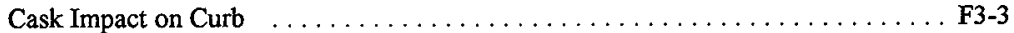

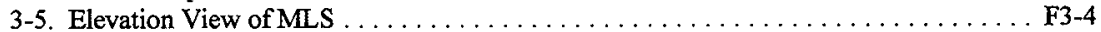

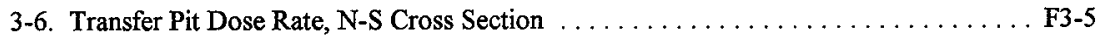

3-7. Transfer Pit Dose Rate, E-W Cross Section . . . . . . . . . . . . . . . F F-6

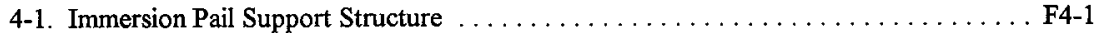

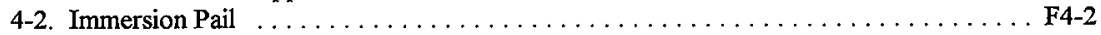

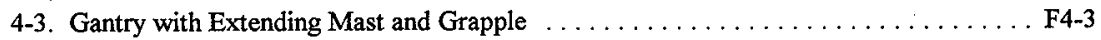

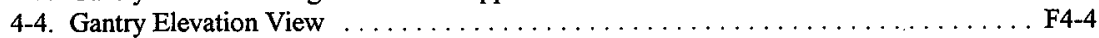

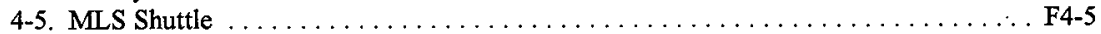

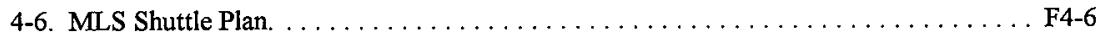

4-7. MLS Shuttle Conceptual Design Modification ................... F4-7 
HNF-2456, Rev. 0

LIST OF TABLES

2-1. Major Components of the Cask Loadout System $\ldots \ldots \ldots \ldots \ldots \ldots \ldots \ldots \ldots . \ldots \ldots$

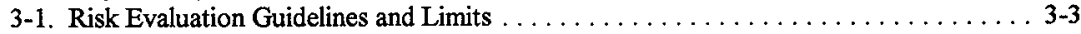

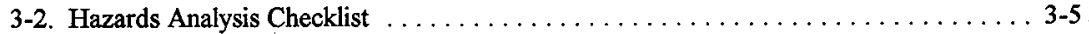

3-3. General Criteria for Frequency Assessment $\ldots \ldots \ldots \ldots \ldots \ldots \ldots \ldots \ldots$ 3-7

3-4. General Criteria for Consequence Assessment .................... 3-8

3-5. Summary of Category $\mathbf{S} 2^{*}$ and $\mathbf{S 3}$ Hazard and Operability Items $\ldots \ldots \ldots \ldots \ldots .3-9$

3-6. Summary of Category $S 1$ Hazards and Operability Items . . . . . . . . . . . 3-10

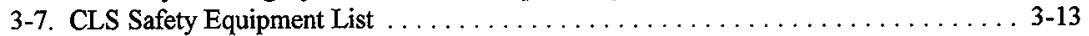

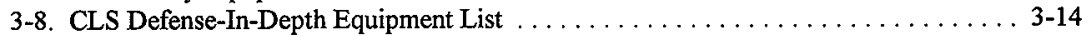

3-9. Binned Listing of Candidate Accidents Sorted by Risk Ranking . . . . . . . . 3-16

3-10. Summary of Unmitigated Dose Consequences - Ignition of Scrap Equivalent to 42 Fuel

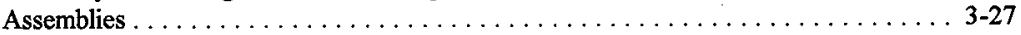

3-11. Summary of Unmitigated Dose Consequences - Oxidation of MCO Fuel Basket . . . 3-28

3-12. Summary of Unmitigated Dose Consequences-Ignition of Scrap Equivalent to 42 Fuel Assemblies (Beyond Design Basis) . . . . . . . . . . . . 3-34

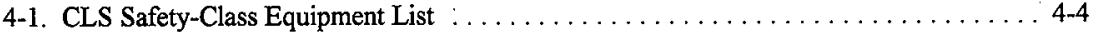

5-1. Candidate TSR, IPSS Locking Pins, to Support the CLS . . . . . . . . . . . 5-1

5-2. MCO Product Specification Affecting the Cask Loadout System ........... 5-2 
HNF-2456, Rev. 0

\section{TERMS}

$\begin{array}{ll}\text { ARF } & \text { Airborne release fractions } \\ \text { AISC } & \text { American Institute of Steel Construction } \\ \text { ALARA } & \text { as low as reasonably achievable } \\ \text { ASME } & \text { American Society of Mechanical Engineers } \\ \text { ANSI } & \text { American National Standards Institute } \\ \text { CI } & \text { cask installation } \\ \text { CLS } & \text { cask loadout system } \\ \text { CPS } & \text { criticality prevention specifications } \\ \text { CR } & \text { cask removal } \\ \text { CSB } & \text { Canister Storage Building } \\ \text { CSER } & \text { criticality safety evaluation report } \\ \text { CTS } & \text { cask transportation system } \\ \text { DBA } & \text { design basis accidents } \\ \text { DESH } & \text { DE\&S Hanford, Inc. } \\ \text { DOE } & \text { U.S. Department of Energy } \\ \text { EDE } & \text { effective dose equivalent } \\ \text { FDNW } & \text { Fluor Daniel Northwest } \\ \text { FHA } & \text { Fire Hazard Analysis } \\ \text { FRS } & \text { Fuel Retrieval Subproject } \\ \text { GECM } & \text { grapple extension compliance mechanism } \\ \text { HAZOPS } & \text { hazards and operability study } \\ \text { IPSS } & \text { immersion pail support structure } \\ \text { LCO } & \text { limiting conditions for operation } \\ \text { LVDT } & \text { linear variable differential transducer } \\ \text { MAR } & \text { material at risk } \\ \text { MCO } & \text { multi-canister overpack } \\ \text { ML } & \text { MCO loading } \\ \text { MLS } & \text { MCO loading system } \\ \text { NRC } & \text { U.S. Nuclear Regulatory Commission } \\ \text { PHA } & \text { Preliminary hazards analysis } \\ \text { RF } & \text { respirable fractions } \\ \text { SAD } & \text { safety analysis document } \\ \text { SAR } & \text { safety analysis report } \\ \text { SIH } & \text { standard industrial hazard } \\ \text { SNF } & \text { spent nuclear fuel } \\ \text { SSC } & \text { structures, systems, and components } \\ \text { TSR } & \text { technical safety requirements } \\ \text { USQ } & \text { unreviewed safety question } \\ & \end{array}$


HNF-2456, Rev. 0

This page intentionally left blank. 
HNF-2456, Rev. 0

\subsection{SITE CHARACTERISTICS}

Site characteristics are described in WHC-SD-WM-SAR-062, K Basins Safety Analysis Report (DESH 1998). Implementing the cask loadout system (CLS) will not change the K Basin site characteristics because the CLS is located completely within the K Basins, which are covered by the existing description. Wind effects during cask delivery are mitigated with a windbreak structure constructed adjacent to the transfer bay roll-up doors.

The only design basis natural phenomenon identified in the K Basin SAR that applies to the CLS is the design basis earthquake.

\section{REFERENCE}

DESH, 1998, K Basins Safety Analysis Report, WHC-SD-WM-SAR-062, Rev. 3D, DE\&S Hanford, Inc., for Fluor Daniel Hanford, Inc., Richland, Washington. 
HNF-2456, Rev. 0

This page intentionally left blank. 
HNF-2456, Rev, 0

\subsection{FACILITY DESCRIPTION}

\subsection{INTRODUCTION}

This chapter describes the systems and equipment for loading and removing spent nuclear fuel (SNF) from the $\mathrm{K}$ Basins. This chapter also covers the cask loadout process, including multicanister overpack (MCO) loading and cask handling.

The following major pieces of the cask loadout system (CLS) equipment will be added to the $\mathrm{K}$ West and $\mathrm{K}$ East Basins:

- $\quad$ MCO loading system (MLS) shuttle

- MLS gantry

- Immersion pail support structure (IPSS)

- Immersion pail.

The following physical modifications will be made to the $\mathrm{K}$ East and $\mathrm{K}$ West Basins:

- Add a windbreak structure to the transfer bay entrance

- Modify the mezzanine structure to accommodate the gantry

- Modify the basin grating to accommodate the new CLS equipment and operations

- Add tie-ins to the electrical, water, and compressed air systems.

The CLS interfaces with the following equipment or systems are described:

- $\quad$ Fuel Retrieval Subproject (Peck 1998)

- Integrated water treatment system (Semmens 1998)

- $\quad$ K Basin transfer crane (DESH 1998a)

- $\quad$ MCO and MCO baskets (Lorenz 1997)

- Cask transportation system (CTS) (Edwards 1998).

Refer to WHC-SD-WM-SAR-062, K Basins Safety Analysis Report (SAR)

(DESH 1998a), for a description of the existing $\mathrm{K}$ Basin facilities and processes.

\subsection{REQUIREMENTS}

The facility standards and requirements are found in HNF-SD-SNF-RD-001, SNF $K$ Basins and Cold Vacuum Drying Facility Standards/Requirements Identification Document, (DESH 1998b). The specific standards and requirements that apply to the CLS equipment are found in WHC-S-0396, Performance Specification for TN-WHC Cask and Transportation System (Kee 1995) and WHC-S-0546, Performance Specification for SNF $K$ East and $K$ West MCO Loading System (Brisbin 1997a). 


\subsection{FACILITY OVERVIEW}

Refer to the K Basins SAR (DESH 1998a) for an overview of the K Basin facilities. The CLS is contained wholly within the $105 \mathrm{KW}$ and $105 \mathrm{KE}$ building.

\subsection{STRUCTURES}

Refer to the K Basin SAR (DESH 1998a) for a description of the existing K Basin structures. The new windbreak structure is described in the following paragraph.

A self-supporting windbreak structure is used to minimize the spread of contamination while the transfer bay door is open to allow the cask transport truck to pass through. The windbreak is attached to the existing $105 \mathrm{KE}$ and $\mathrm{KW}$ building at door 157 . The windbreak has a frame, two side walls, a gabled roof, and a $14-\mathrm{ft}$ by $22-\mathrm{ft}$ doorway in front. The front doorway is covered by a clear vinyl strip door. Three additional clear vinyl strip doors are spaced along the inside length of the structure. The internal doors and walls minimize wind effects in the building.

\subsection{PROCESS DESCRIPTION}

This section describes the systems, equipment, and operation associated with loading the SNF at each K Basin facility. Figure 2-1 shows the Cask-MCO loading process. Figures 2-2 through 2-8 provide plan and elevation views of the loading areas and associated equipment and systems.

The CLS includes the immersion pail system and the MLS. The major components of the CLS are identified in Table 2-1. The cask loadout process interfaces with the following equipment:

- Fuel Retrieval Subproject MCO baskets stiffback grapple

- MCO and MCO baskets

- Integrated water treatment system

- K Basins transfer bay crane

- Cask transport system.

The CLS equipment has been engineered to

- Minimize cycle times

- Control contamination

- $\quad$ Provide operating margins of safety

- Minimize waste generation

- Minimize personnel exposure

- Support ease of operation by facility personnel. 
HNF-2456, Rev. 0

Table 2-1. Major Components of the Cask Loadout System.

\begin{tabular}{|l|l|}
\hline \multicolumn{1}{|c|}{ System } & \multicolumn{1}{c|}{ Major component } \\
\hline Immersion Pail System & $\begin{array}{l}\text { Immersion Pail Support Structure. A vertical steel frame installed in the } \\
\text { south loadout pit to support and guide the immersion pail. }\end{array}$ \\
\cline { 2 - 3 } & $\begin{array}{l}\text { Immersion Pail. A large container and lid used to minimize radioactive } \\
\text { contamination of the outside of the cask from the basin water when the } \\
\text { Cask-MCO is submerged for loading. }\end{array}$ \\
\hline MCO Loading System & $\begin{array}{l}\text { Shuttle. A cart and supporting frame located in the transfer channel used to } \\
\text { move loaded MCO baskets from a position over the FRS MCO basket queue } \\
\text { to a position next to the IPSS. }\end{array}$ \\
\hline $\begin{array}{l}\text { Gantry. A single-axis bridge lifting device that spans the transfer channel } \\
\text { and travels east-west from a position next to the IPSS to a position directly } \\
\text { over the Cask-MCO. The gantry is used for loading MCO baskets into the } \\
\text { MCO. }\end{array}$ \\
\hline
\end{tabular}

FRS $\quad=$ Fuel Retrieval Subproject.

IPSS = Immersion pail support structure.

$\mathrm{MCO}=$ Multi-canister overpack.

The cask loadout process begins when a cask is delivered into the basin on a transport trailer. The Cask-MCO is unloaded from the transport trailer using the transfer bay crane and inserted into the immersion pail in the top position of the IPSS. The cask lid and the MCO locking and lifting ring are removed. The immersion pail lid is installed to seal the cask and MCO so basin water cannot contaminate the outside surfaces of the Cask-MCO, then the annulus between the $\mathrm{MCO}$ and the cask is filled with clean water. Lifting slings are installed and the immersion pail is lowered to the bottom of the IPSS. All lifts will be performed following the procedures found in DOE/RL-92-36, Hoisting and Rigging Mamual (DOE-RL 1992).

Loaded MCO baskets are removed from the Fuel Retrieval Subproject (FRS) MCO basket queue (see Fuel Retrieval Subproject safety assessment document [Peck 1998]), which is adjacent to the south loadout pit transfer channel east entrance, and placed on the MLS shuttle. The MLS shuttle moves the MCO basket through the transfer channel and stops next to the Cask-MCO. The MCO basket is lifted from the shuttle and loaded into the MCO with the MLS gantry. This process is repeated until the MCO is fully loaded. (A fully loaded MCO contains either six Mark IA baskets or five Mark IV baskets.) Once the MCO is loaded, the MCO shield plug is installed. The cask and immersion pail are lifted and secured in the top position of the IPSS with locking pins. The immersion pail lid is removed and the MCO locking and lifting ring and cask lid are installed. The MCO is backfilled with helium using a feed-and-bleed process through the cask secondary vent port. The loaded cask is then removed from the immersion pail and loaded on the cask transport trailer for transport to the Cold Vacuum Drying Facility.

Safety-class and safety-significant structures, systems, and components are described in detail in Chapter 4. 
HNF-2456, Rev. 0

\subsubsection{CLS Equipment Description}

This section describes the major pieces of equipment associated with the CLS.

2.5.1.1 Immersion Pail Support Structure. The IPSS consists of a two-section steel frame. One section rests on and is pinned to the top of the other. The IPSS is approximately 320 in. high. The IPSS is secured in the south loadout pit by manually operated jacks and the existing guide rails. The corner columns of the IPSS act as guide rails to guide the immersion pail as it is raised and lowered in the IPSS. Manually operated locking pin assemblies are mounted to the top of each IPSS corner column to secure the immersion pail in the raised position. The locking pins are designed to be locked in the inserted or retracted position. The IPSS has a 48-in. by 56-in. base plate that connects and supports the corner columns. The IPSS base plate supports the immersion pail when it is in the lowered position.

2.5.1.2 Immersion Pail. The immersion pail consists of a 165.5-in.-tall thin-walled circular cylinder with a bottom plate. Part of the immersion pail is surrounded by a steel-lined foam-filled floatation cavity. When in the raised position, the immersion pail top is located at the top of the south loadout pit curb to reduce cumulative operator dose to levels that are as low as reasonably achievable (ALARA) (Brisbin $1997 \mathrm{~b}$ and Lan 1996).

The Cask-MCO assembly is supported in the immersion pail. The immersion pail bottom plate carries the cask load to the immersion pail wall, which transmits the load to the top shell ring and four immersion pail lifting lugs. The immersion pail lifting lugs are supported by the IPSS locking pins and the IPSS. When the immersion pail is being raised or lowered the immersion pail lifting lugs are supported by the crane lifting lugs. When the immersion pail is raised or lowered, the immersion pail lifting lugs are guided by the IPSS corner columns. The immersion pail bottom plate transmits the cask load to the IPSS base plate when the immersion pail is in the lowered position for MCO loading.

The immersion pail includes a lid to seal the Cask-MCO to minimize contamination while submerged in the basin water. The doughnut-shaped immersion pail lid is a stainless steel weldment with inflatable seals between the immersion pail, the immersion pail lid, and MCO interfacing surfaces. Three lifting lugs are provided to handle the immersion pail lid. An elevated reservoir tank filled with demineralized water attached to the immersion pail lid provides positive pressure to the immersion pail cavity to ensure that any seal leakage is into the basin, minimizing contamination of the outside surfaces of the Cask-MCO.

2.5.1.3 MCO Loading System Shuttle. The MLS shuttle is used to move MCO baskets from the FRS MCO basket queue through the south loadout pit transfer channel to the MCO basket load position, just east of the IPSS. The shuttle cart provides approximately $11.5 \mathrm{ft}$ of travel. The shuttle cart uses corrosion-resistant rollers that ride on parallel rails. The rails are supported by a structural steel framework suspended from the operations deck (Figure 2-3). The shuttle includes seismic restraints designed to withstand a design basis earthquake (Brisbin 1997a). Shock absorbers and "hard stops" are provided to control the shuttle cart position. The MLS shuttle cart drive system consists of a fixed-length cable connected to a pneumatic cylinder on each side of the shuttle cart toward the east end. The shuttle cart is attached to the cable at the 
center of system travel. The pneumatic cylinders are located outside the pool; only the cylinder rods are exposed to the basin water. The cable, pulleys, and shuttle frame and cart system equipment are permanently located beneath the water surface. On activation, one cylinder retracts, the opposite cylinder extends, and the cart is pulled by the cable to the end of the shuttle rail against a hard stop. To minimize the potential for airborne contamination, the cylinder rods are immediately sleeved by the cylinders (design) as they are raised from the pool surface.

The shuttle is installed so that the east end is directly over the FRS MCO basket queue to ease loading operations and prevent $\mathrm{MCO}$ baskets from being loaded into non-qualified storage positions in the FRS MCO basket queue (Peck 1998).

The shuttle is currently undergoing a design modification that will incorporate features that address the energy-absorption safety function required during a seismically induced $\mathrm{MCO}$ basket drop.

2.5.1.4 MLS Gantry. The gantry is installed on the gantry support structure primarily consisting of two carbon steel I-beams (W10X45) forming rectangular frames bolted to the operations deck and attached to existing W6X45 platform columns reinforced with W6 tube steel bracing. The gantry support structure spans the south loadout pit from north to south. The gantry moves up and down and from the $\mathrm{MCO}$ basket unload position on the east side of the south loadout pit west to the MCO load position. Its horizontal movement is limited by its 57 -in. width and hard stops at each end of its route. It is designed so that, once installed, it cannot move north or south. Drive motion is provided by a rack-and-pinion gear linear-bearing arrangement. The gantry motion is controlled by a servo motor drive with a gear reducer. The arrangement includes redundant limit switches and hard-stop backups. The gantry and its support structure are designed to be installed so that its ability to lift an MCO basket is limited to a maximum elevation of $-8 \mathrm{ft} 0$ in. (Brisbin 1997c).

The gantry supports a vertical mast with a grapple. The mast is raised and lowered to lift and position the MCO basket in the MCO. The gantry is designed to limit the lift height of an MCO basket. The grapple is designed with a ball detent mechanism that engages a groove in the MCO basket center pipe. The grapple is pneumatically operated by a cylinder mounted in the grapple extension compliance mechanism (GECM). The mast is positioned by a linearly guided ballscrew drive that raises and lowers the grapple. The ballscrew is driven by a servo motor and programmable controller providing full-range positioning capabilities. The mast incorporates a GECM connected to a linear variable differential transducer. The GECM provides compliance to the extending mast by allowing the column to retract up to 2 in. before the assembly is exposed to compressive loading. A control system monitors MCO loading and stops all mast motion if loading is outside normal limits.

A video camera mounted at the base of the mast focuses on the grapple. The mast video camera monitors all grapple operations and the top of the MCO basket. 
2.5.1.5 Interfacing Equipment Description. The CLS interfaces with the Fuel Retrieval Subproject, the integrated water treatment system, the Cask-MCO into which MCO baskets are loaded, the transfer bay crane, and the CTS. Sections 2.5.1.5.1 through 2.5.1.6.5 briefly describe the interfacing equipment and the interfaces.

2.5.1.5.1 Fuel Retrieval Subproject. The Fuel Retrieval Subproject includes an FRS $\mathrm{MCO}$ basket queue where the MCO baskets are stored before being loaded into the MCO. The Fuel Retrieval Subproject flexible transfer crane and MCO basket stiffback grapple are used to move the MCO baskets from the queue to the MLS shuttle.

2.5.1.5.2 Transfer Bay Crane. The 32-ton transfer bay bridge cranes are used to lift and move the Cask-MCO and the immersion pail.

2.5.1.5.3 Multi-Canister Overpack. The MCO, shown in Figure 2-6, is a vertical, cylindrical stainless steel container used to transport and store SNF. A shield plug is inserted into the top of the MCO. The shield plug has an annular section cut out of the top where the MCO locking and lifting ring is placed. The locking and lifting ring is threaded on the outside, mating with threads on the inside of the MCO shell collar. Eighteen $1 \frac{11}{2}$ in. bolts penetrate the locking and lifting ring to further compress the $\mathrm{MCO}$ seal. The top of the shield plug has four penetrations that connect to plug valve actuators; they are used to dry the fuel inside the MCO. For shielding purposes, all four penetrations have double bends as they penetrate the shield plug (Edwards 1998). The primary seal seals the MCO shell to the shield plug.

The locking ring is a stainless steel forging threaded into the buttress threads on the MCO collar after the MCO is removed from the pool. This ring provides a grapple interface for $\mathrm{MCO}$ handling and support for the bolts that preload the shield plug and the seal. Eighteen set screws are threaded into the locking ring. The screws serve as jacking bolts to preload the seal. An integral compression limiter sets the strain on the seal.

The MCO fuel assembly and scrap baskets have different designs depending on the average fuel enrichment (Mark IA at 1.15 percent and Mark IV at 0.95 percent). The Mark IA assembly baskets are designed to accommodate fuel assemblies that are $20.91 \mathrm{in}$. long and $2.40 \mathrm{in}$. in diameter; Mark IV assembly baskets accommodate fuel assemblies up to $26.1 \mathrm{in}$. Iong and 2.42 in. in diameter.

The MCO baskets are loaded into the MCO using the MLS gantry. The MCO baskets are lifted by a ball detent grapple that engages a groove on the interior of the center tube of the MCO basket. This grapple is the same design as that used by the Fuel Retrieval Subproject MCO stiffback.

2.5.1.5.4 Cask and Transportation System. The CTS is used to safely transport the SNF from the $105 \mathrm{~K}$ East and K West Basins to the $100 \mathrm{~K}$ Cold Vacuum Drying Facility. The CTS consists of five TN-WHC casks and five dedicated semi-trailers (Edwards 1998). The CTS is designed to transport the Cask-MCO containing a single loaded MCO oriented vertically. 
HNF-2456, Rev. 0

Cask. The MCO is positioned inside the cask. The MCO and cask are removed from the CTS and loaded into the CLS immersion pail using the transfer bay crane. The immersion pail and Cask-MCO are then submerged in the IPSS by the transfer bay crane to load MCO baskets into the $\mathrm{MCO}$.

The cask is classified as a safety-class component and is described in full detail in the safety analysis report for packaging (Edwards 1998). It is engineered to minimize loading, decontamination, handling, and cask maintenance, thereby maximizing in-service time.

The cask is approximately $170 \mathrm{in.} \mathrm{long} \mathrm{and} 40 \mathrm{in}$. in diameter. The cask body is fabricated from stainless steel forgings with a bolted-on stainless steel lid. The lid is attached to the cask body with 12 bolts captured in the lid to prevent them from being dropped during bolting or unbolting, as described in the safety analysis report for packaging. A single rubber o-ring seal forms the containment boundary between the cask body and the lid. The lid installation is guided by two alignment pins that are integral to the cask body. Two lifting brackets are welded to the cask lid for lifting the cask with the lid. The brackets protrude $20 \mathrm{in}$. from the lid surface with a 4-in.-diameter trunnion welded to each bracket. The maximum gross weight of the loaded cask is approximately $58,000 \mathrm{lb}$.

The cask is designed to be handled and transported only in the vertical position. During transport, the cask is supported on the trailer by an upper tie-down device and a lower cupshaped retainer.

Transport. The transport system is used to move the Cask-MCO into and out of the transfer bay. The transport system is a semi-trailer that can be attached to a standard tractor. The trailer provides the necessary supports and attachment points for securing the cask in the vertical orientation. Major dimensions of the trailer are as follows (Brisbin 1997b):

- Overall length: $40 \mathrm{ft}$; with a tractor approximately $54 \mathrm{ft}$

- Overall width: $10 \mathrm{ft}$

- Overall height: $17 \mathrm{ft}-7$ in. (loaded at top of the cask lifting attachment)

- $\quad$ Loaded deck height: $3 \mathrm{ft}$

- Loaded ground clearance 12 in.

Figure 2-5 shows the CTS.

2.5.1.5.5 Integrated Water Treatment Subproject. The integrated water treatment subproject provides demineralized water, which is fresh makeup water used to fill the immersion pail/cask annulus and for decontamination activities. Also, the integrated water treatment system provides deionized water to fill the MCO before it is lowered into the immersion pail and to flush the potential contaminants from the south loadout pit. 
HNF-2456, Rev. 0

\subsubsection{CLS Operation Description}

2.5.2.1 Cask-MCO Receipt and Loading Preparation. Preparation for loading the Cask-MCO begins when a transport from the CSB, carrying an empty Cask-MCO, arrives outside the windbreak structure at the basin transfer bay. The transfer bay roll-up door (No. 157) is opened and the tractor positions the trailer carrying the Cask-MCO in the transfer bay. Exhaust trunks are connected to the tractor as required by the Industrial Safety department.

The following steps may be performed in any order by operations as the procedures are generated. Once the trailer is positioned in the transfer bay, the trailer jacks are lowered and the trailer is disconnected from the tractor. The exhaust trunks are removed and the tractor is moved outside the transfer bay to an area clear of the windbreak. The trailer is connected to the building compressed air system. The trailer is leveled using the landing gear. The transfer bay door is then lowered. A radiation survey of the Cask-MCO is completed to ensure that contamination levels are within acceptable limits.

The four quick-release locking pins from the cask hold-down device are removed, freeing the cask for vertical movement. The hooks for the transfer bay crane are aligned and engaged with the cask-lifting trunnions; the crane hoist applies tension to the wire ropes and cask load. The cask clamp is swung open, freeing the cask for lateral movement. The transfer bay crane is then used to lift the Cask-MCO clear of the trailer and tie-down device and move it from the transport trailer to the area above the south loadout pit. All Cask-MCO lifts will be performed using a critical lift procedure in accordance with the DOE/RL-92-36, Hoisting and Rigging Mamial (DOE-RL 1992).

Two other activities occur in parallel with cask receipt at the $\mathrm{K}$ Basins. The first is inspecting the immersion pail lid and the immersion pail in preparation for transferring the Cask-MCO from the trailer into the immersion pail. First, the seal surface of the pail lid is inspected for damage that might affect the inflatable seal. Next, the inflatable seal is inspected for wear (including cracking and feathering) and, if necessary, replaced. Next, installation of the pail lid fasteners in their captive position is visually verified. The lift sling is installed at this time, with one sling leg on each of the three pail lid lift lugs. The pail lid is ready for installation on the pail. The second activity begins by inspecting the immersion pail for proper position in the IPSS and correct pail lock position. The inside of the pail is visually inspected to ensure that it is free of foreign material or debris. The pail sealing surface is inspected for nicks, scars, or gouges that might affect the inflatable seal. The immersion pail water level is then checked to verify that water in the pail has reached the correct level. Demineralized (i.e., fresh makeup) water is added as required. At this point, the pail is ready to receive the Cask-MCO.

Before lowering the Cask-MCO into the immersion pail, the cask position over the loadout pit is verified relative to the immersion pail. The transfer bay crane lowers the Cask-MCO into the immersion pail until the cask rests on the bottom. The transfer bay crane hooks are disconnected and removed from the cask. The auxiliary hoist is used to install a cask torquing tool and the cask lid bolts are loosened. When the lid bolts are verified to have disengaged from the cask, the torquing tool is removed and stored. Then the transfer bay crane 
hooks are connected to the cask lid and the cask lid is removed. The cask lid is positioned on the cask lid storage tool where the o-ring is visually inspected for wear.

The lift sling is connected to the immersion pail lid. The immersion pail lid is lowered into place using guide pins to ensure correct positioning. The four pail lid retention fasteners are engaged, and the immersion pail lid seals are inflated to 45 psi gage maximum using the building compressed air. The annular region of the immersion pail and cask is filled with demineralized water by the water supply for the immersion pail and cask annulus and is maintained at a pressure slightly higher than the pressure in the loadout pit to minimize contamination.

The MCO locking ring is removed using the locking ring tool. The locking ring tool is calibration tested then installed using the auxiliary hoist. When the locking ring tool is positioned, the grapple attaches to the rim of the locking ring. The hydraulic jacks are actuated by manually rotating the 40 -in. wheel on the locking ring tool. The locking ring is captured in the locking ring tool and the assembly is removed using the auxiliary hoist. Then the locking ring tool is surveyed for contamination, and placed in an uncontaminated storage area. Approximately $40 \mathrm{gal}$ of deionized water from the integrated water treatment system are added to the MCO cavity to offset the buoyant effect of water in the cask annular region.

The MCO basket guide is installed in the mouth of the Cask-MCO. The basket guide protects the internal shield plug retainer threads and sealing surface as baskets are inserted and aligns the baskets during the loading process.

The immersion pail lift beam is attached to the hooks on the transfer bay crane and the lift beam is positioned over the immersion pail. The lift beam is set at an elevation that facilitates attachment of the immersion pail lift slings. The hook end of each sling is attached to a lift beam master link. The lift beam is slowly raised until there is tension in the slings; then all connections are verified and checked for uneven loading. The immersion pail is slowly raised again until the red alignment lines on the lifting lugs are exposed at the lock pin housings. The locking pin gates are lifted and the locking pins are pulled out until the pin gates can be closed with the pin in the disengaged position; this ensures full retraction.

Deionized water from the integrated water treatment system is added to the MCO cavity to assist in submersion, then the immersion pail is lowered approximately $2 \mathrm{ft}$ and held in position while the immersion pail lid seal area is checked for leaks. The immersion pail is lowered until it rests on the IPSS bottom plate. The immersion pail slings are removed, then the immersion pail lift beam is removed from the pit area and disconnected from the transfer bay crane hooks.

2.5.2.2 MCO Loading. The MCO baskets are moved from the FRS MCO basket queue to the MLS shuttle using the two-ton flexible transfer crane and the MCO basket stiffback grapple. An underwater camera is used to verify that fuel does not extend above the top of the MCO basket to ensure that the next basket to be loaded will seat properly. Following successful verification, the shuttle is actuated at the MLS control and monitoring station, and the MCO basket is moved from east to west through the transfer channel with the shuttle next to the IPSS. The MLS control and monitoring station is remotely located in Corridor 7. 
The gantry mast and grapple assembly (Figure 2-8) is used to load the MCO basket into the Cask-MCO. The MCO basket is lifted by extending the mast to the basket on the shuttle and energizing the grapple cylinder. The grapple anti-release mechanism locks automatically. The MCO basket is then lifted approximately 1 in. to verify that the load is within the appropriate weight range for the specific MCO basket type using the load cell readout. The MCO basket is lifted to approximately the -8 -ft 6-in. elevation and centered over the Cask-MCO. The shuttle then is returned to a position next to the queue. The MCO basket is then lowered to the proper loading position within the $\mathrm{MCO}$.

After the no-load signal is received, the gantry mast is lowered an additional 1.25 in. to disengage the grapple anti-release mechanism. The gantry mast lowers an additional 0.25 in. to completely disengage the grapple. The operator reviews the console display to verify no load on the load cell, correct height position on the controls, and correct grapple motion pin position for release. Following verification, the grapple is opened and the basket is released. The mast is lifted 2 in. and the load cell readout is monitored to verify a " dead load" consisting of mast weight only. Following verification, the mast and the gantry are returned to the shuttle unload position.

This MCO loading process is repeated until the MCO is full. The basket guide is removed from the Cask-MCO using a pole hook or rope hook and stored in the transfer bay. A tool rack located along the handrail above the loadout pit platform will be used to store tools.

2.5.2.3 Shield Plug Installation. The shield plug, o-ring, and process tube assembly are assembled in the K Basin transfer bay. The shield plug handling fixture seal is inspected and attached to the shield plug. This handling fixture allows the shield plug to be lifted with a crane, keeps the shield plug top free of contamination during underwater insertion into the $\mathrm{MCO}$, and provides a means to decontaminate and dry the area between the fixture and the MCO threads. The lift rig is attached to the shield plug handling fixture and connected to the auxiliary hook on the transfer bay crane. The shield plug assembly is lifted vertically to mezzanine height, placed in the shield plug support stand, and oriented to install the process tube assembly. The shield plug support stand is a fixture attached to the mezzanine that reduces shield plug movement during process tube installation.

The process tube is installed in the shield plug using the mezzanine for access. A mezzanine deck height of $12.5 \mathrm{ft}$ allows the required access to lift the 12.25 - $\mathrm{ft}$-long process tube. The process tube handling tool is used to lift, position, and tighten the process tube. The process tube connection is leak tested to ensure a good seal. A final inspection of the shield plug and o-ring is completed to ensure that they are clean and in good condition. The shield plug seal area on the $\mathrm{MCO}$ is cleaned to remove debris.

The shield plug assembly is positioned over the $\mathrm{MCO}$ and lowered into the MCO. The shield plug is checked to ensure proper seating, correct shield plug installation depth, and alignment of the shield plug ports. The lifting rig is released and the auxiliary hoist is moved out of the way; then the lifting rig is removed from the auxiliary hook. 
2.5.2.4 Cask-MCO Loadout and Preparation for Transfer. The immersion pail beam is reattached to the hooks of the transfer bay crane, and the lift beam is positioned over the immersion pail. The hook end of each immersion pail lift sling is attached to the immersion pail lift beam master links. The lift beam is slowly raised until there is tension in the slings; all connections are verified and checked for even loading.

The immersion pail is slowly raised to the water surface, where the immersion pail lid and shield plug handling fixture surfaces are rinsed thoroughly with demineralized water; the shield plug handling fixture top is surveyed for contamination. Following the survey, the pail continues to be raised and rinsed until the red immersion pail lift lug alignment lines are visible over the IPSS locking pin housings. The locking pin gates are then lifted, and the locking pins are manually extended until the gates can close; the pail is lowered until its weight rests on the locking pins. This secures the immersion pail in the upper position. The slings are disconnected and the ends are fed into the sling storage box. The sling hooks are disconnected and attached to the side of the loadout pit grating structure. The immersion pail lift beam is removed and stored on a portable storage rack that can be moved out of the way of westerly crane travel in the center bay. The shield plug handling fixture is removed from the shield plug. Then the handling fixture is raised from the MCO, taken from the loadout pit area, and placed in a staging rack.

After the shield plug handling fixture is removed, the locking ring is installed. When the locking ring tool is in position, the locking ring is rotated until seated. When the locking ring is seated, the hydraulic wrenches on the locking ring tool are actuated; simultaneously, the 18 wrenches apply the appropriate torque to the corresponding 18 bolts.

The pressure to the immersion pail lid MCO seal is broken, allowing clean water from the immersion pail water reservoir to flush the seal annulus. The water reservoir is isolated. The immersion pail lid and surrounding area are rinsed thoroughly with demineralized water.

The four immersion pail lid bolts are loosened and captively engaged in the lid. The pressure to the immersion pail lid pail seal is released. The immersion pail lid sling is attached to the auxiliary hoist and the pail lid. Then the immersion pail lid is slowly raised from the immersion pail and placed in storage on a pedestal inside the curbed decontamination area. The immersion pail lid sling is removed from the transfer bay crane and stored.

The cask water level is adjusted using a suction tool and visually verified. The transfer bay crane hooks are positioned over the cask lid, then attached to the cask lid trunnions. The cask lid is lifted and positioned over the cask; the alignment with the cask guide pins is verified. The lid is then placed on the cask. The transfer bay crane hooks are removed from the cask lid trunnions and the crane is positioned over the cask lid torque tool. The auxiliary hoist is attached to the cask lid torque tool. The cask lid torque tool is moved over the cask lid and lowered into position for torquing. The lid is fastened to the cask using the cask lid torque tool.

The cask secondary vent port cover is removed in preparation for adding inert gas (Klimper 1998). When the appropriate gas composition is reached, the Cask-MCO meets safety requirements for shipping. Helium is fed into the cask through a multiple-cycle feed-and-bleed process to reduce the oxygen content and prevent the possibility of ignition. The gas adjustment 
equipment is removed and the dust cover is replaced. The shipping window begins when the vent port is sealed.

Using the transfer bay crane, the cask is raised from the immersion pail until it can clear the pit wall. Excess water is wiped from the cask as it is removed from the pail. A radiation survey is completed, and the cask is decontaminated if necessary. The cask is then moved from the loadout pit to the trailer area. The cask is aligned and lowered into the trailer support device. Just before reaching the trailer deck, cask lowering is halted, and the cask tie-down devices are closed. One clamp bolt is installed hand tight on each side. Cask lowering is then completed. Any safety chains, handrails, or platforms removed during cask loading operations are reinstalled.

The crane hooks are disconnected and the crane is positioned away from the trailer area. The vertical tie-downs are connected to the cask. The trailer jacks are raised to allow the tractor to pass under the front of the trailer. The transfer bay roll-up door (No. 157) is opened, the trailer is disconnected from the building compressed air, exhaust trunks are connected as required, and the tractor is positioned under the front of the trailer. The trailer is connected to the tractor, a final release survey is conducted, and the cask is transferred to the Cold Vacuum Drying Facility.

2.5.2.5 CLS Equipment Maintenance Requirements. The cask operations equipment for the $\mathrm{K}$ Basin loadout pit includes few mechanical systems and requires little maintenance. Maintenance support is limited to that required as a result of system operations inspections performed before each cask loading cycle and other system inspections performed periodically as identified in the installation, operation, and maintenance manual (Kee 1997). Components that may require maintenance include immersion pail seal lid seals; immersion pail seal lid fasteners; support structure lock pins; demineralized water reservoir seals, hoses, and connectors; air lines and connectors; and lift slings and pail attachments. The integrity of the design and limited operating components make minimal maintenance support necessary (Brisbin 1997c).

The MLS has been designed to provide a high degree of system reliability with minimal maintenance, using easily replaceable equipment where maintenance could be required. The shuttle drive system, consisting of a cable, pulleys, and two pneumatic cylinders, has no maintenance requirements. The gantry drive system is a dual rack-and-spur system capable of the significantly faster speeds, cycle times, and loads required for MCO loading. The stainless steel ballscrew, guide shafts, and grapple interface tooling are designed to operate in the K Basin water. Therefore, MLS maintenance will include mostly periodically confirming that the control equipment set points are adjusted correctly for proper system operation. This includes checking the digital and analog inputs and motion control inputs and outputs (Brisbin 1997b). The maintenance on this equipment incurs only the normal risk associated with standard industrial maintenance. 


\subsection{CONFINEMENT SYSTEMS}

See the current version of the K Basins SAR (DESH 1998a) for a discussion of the $\mathrm{K}$ Basin confinement systems. The cask loadout process will not change these systems.

\subsection{SAFETY SUPPORT SYSTEM}

Existing basin area radiation monitors and continuous air monitors provide safety support. See the current version of the K Basins SAR (DESH 1998a) for a discussion of the K Basin safety support systems for worker protection. The cask loadout process will not change these systems.

\subsection{UTILITY DISTRIBUTION SYSTEM}

The MLS requires the following three circuits:

- One 460 VAC 3-phase, 40-amp circuit (control panel)

- Two $120 \mathrm{~V}, 1$-phase 10-amp circuits (closed-circuit television).

The MLS will be supplied with electrical power from the existing electrical distribution system. See the current version of the K Basins SAR (DESH 1998a) for a discussion of the K Basin utility distribution system.

\subsection{AUXILIARY SYSTEMS AND SUPPORT FACILITIES}

The CLS will be supplied with plant compressed air, demineralized water, and deionized water. See the current vetsion of the K Basins SAR (DESH 1998a) for a discussion of the $\mathrm{K}$ Basin auxiliary systems and support facilities.

\subsection{REFERENCES}

Brisbin, S. A., 1997a, Performance Specification for SNF K East and K West MCO Loading System, WHC-S-0546, Rev. 0, DE\&S Hanford, Inc., for Fluor Daniel Hanford, Inc., Richland, Washington.

Brisbin, S. A., 1997b, Design Analysis Report for the IN-WHC Cask and Transportation System, HNF-SD-SNF-FDR-003, prepared by DE\&S Hanford, Inc., for Fluor Daniel Hanford, Inc., Richland Washington.

Brisbin, S. A., 1997c, Design Review Report for the Hanford K East and K West Basins MCO Loading System, HNF-SD-SNF-DR-004, Rev. 1, 1997, DE\&S Hanford, Inc., for Fluor Daniel Hanford, Inc., Richland, Washington. 
DESH, 1998a, K Basins Safety Analysis Report, WHC-SD-WM-SAR-062, Rev. 3D, DE\&S Hanford, Inc., for Fluor Daniel Hanford, Inc., Richland, Washington.

DESH, 1998b, SNF K Basins and Cold Vacuum Drying Facility Standards/Requirements Identification Document, HNF-SD-SNF-RD-001, Rev. 1, DE\&S Hanford, Inc., for Fluor Daniel Hanford, Inc., Richland, Washington.

DOE-RL, 1992, Hoisting and Rigging Manual, DOE/RL-92-36, U.S. Department of Energy, Richland Operations Office, Richland, Washington.

DOE-STD-1090-96, Hoisting and Rigging, U.S. Department of Energy, Washington, D.C.

Edwards, W. S., 1998, Safety Analysis Report for Packaging (Onsite) Multi-Canister Overpack Cask, HNF-SD-TP-SARP-017, Rev. 1, draft, Waste Management Federal Services Inc., Northwest Division, for Fluor Daniel Hanford, Inc., Richland, Washington.

Kee, A. T., 1995, Performance Specification for the TN-WHC Cask and Transportation System, WHC-S-0396, Rev. 1, Westinghouse Hanford Company, Richland, Washington.

Kee, A. T., 1997, TN-WHC Cask and Transportation System Installation, Operations, Repair, and Maintenance (TORM), HNF-SD-SNF-OMM-003, Rev. 0, DE\&S Hanford, Inc., for Fluor Daniel Hanford, Inc., Richland, Washington.

Klimper, S. C., and A. Pajunen, 1998, Inert Gas Requirements for Cask Loading, HNF-2833, Cogema for Fluor Daniel Hanford, Inc., Richland, Washington.

Lan, J. S., 1996, Recent Dose Rate Calculational Summary for N-Reactor Fuel Handling and Shipping from $K$-Basins, WHC-SD-SNF-CAVR-001, Westinghouse Hanford Company, Richland, Washington.

Lorenz, B. D., 1997, Multicanister Overpack Topical Report, HNF-SD-SNF-SARR-005, Rev. 0, DE\&S Hanford, Inc., for Fluor Daniel Hanford, Inc., Richland, Washington.

Peck, S. H., 1998, SNF Fuel Retrieval Subproject Safety Assessment Document, HNF-2032, Rev. 0, DE\&S Hanford, Inc., for Fluor Daniel Hanford, Inc., Richland, Washington.

Semmens, L. S., 1998, K West Basin Integrated Water Treatment System Subproject Safety Assessment, HNF-SD-SNF-SAD-002, Rev. 1, DE\&S Hanford, Inc., for Fluor Daniel Hanford, Inc., Richland, Washington. 
HNF-2456, Rev. 0

Figure 2-1. Process Flow Diagram.

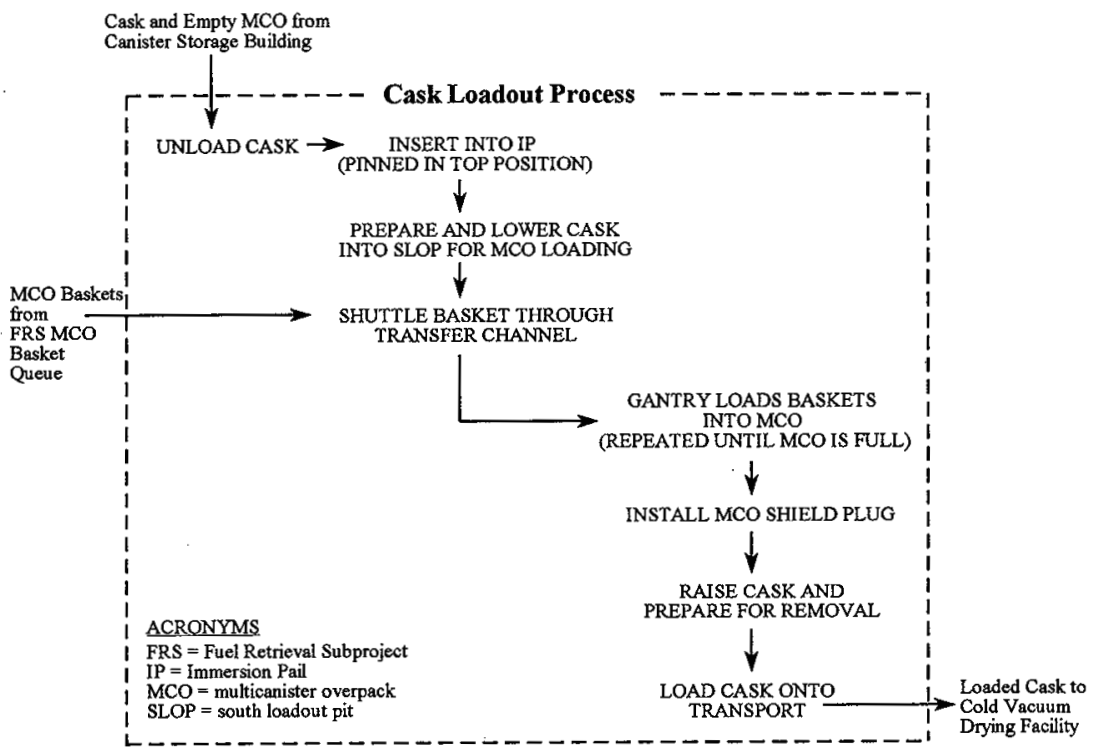


Figure 2-2. Cash Loading System Elevation View.

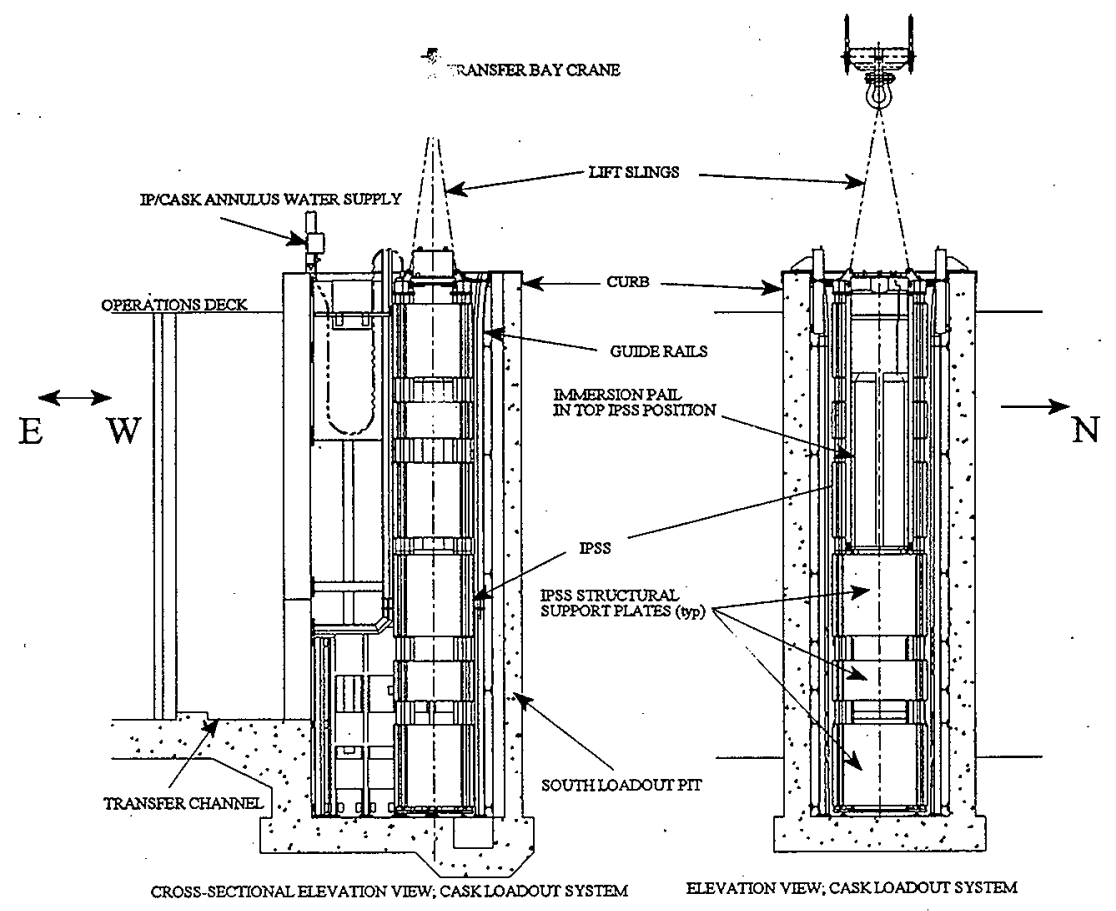


HNF-2456, Rev. 0

Figure 2-3. MCO Loading System Elevation View.

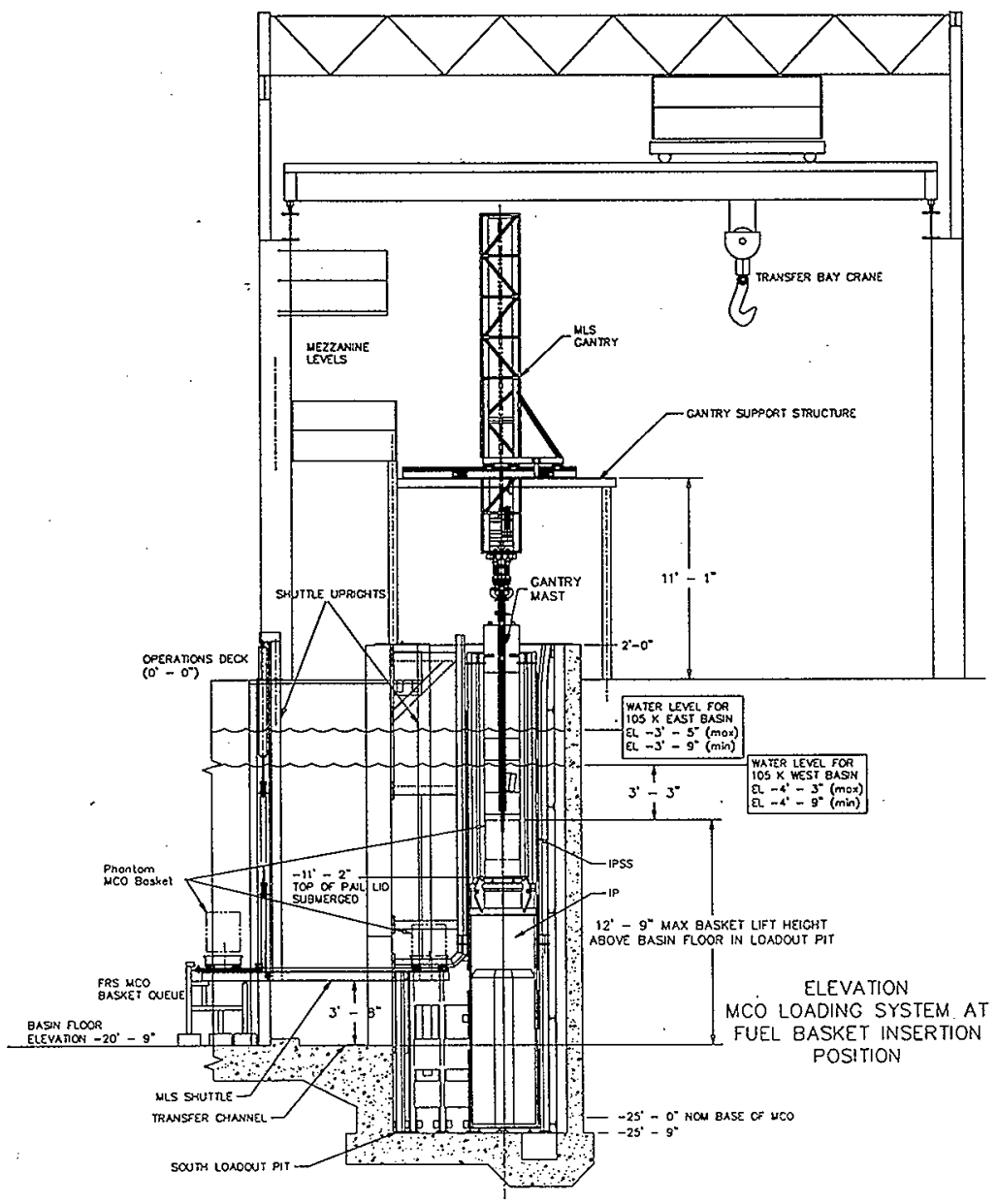


HNF-2456, Rev. 0

Figure 2-4. MCO Loading System Plan View.

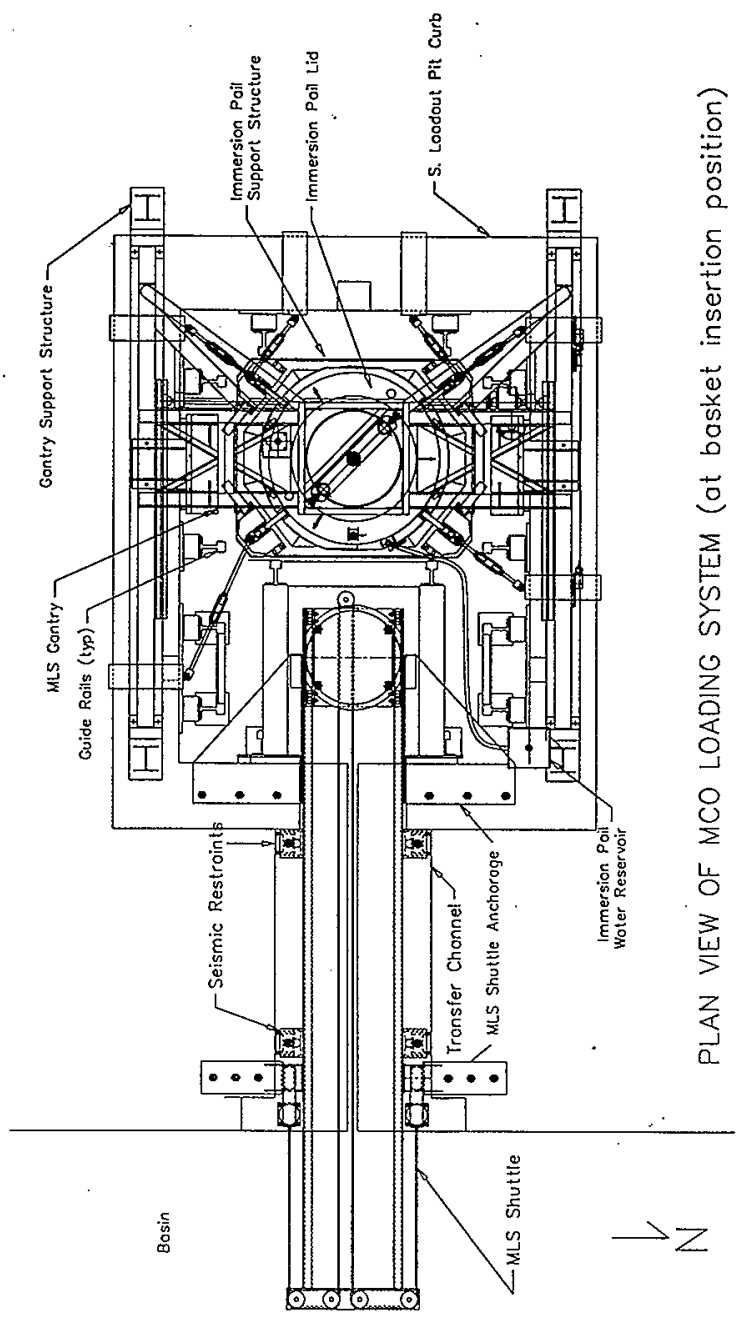


HNF-2456, Rev. 0

Figure 2-5. Cask Transportation System.

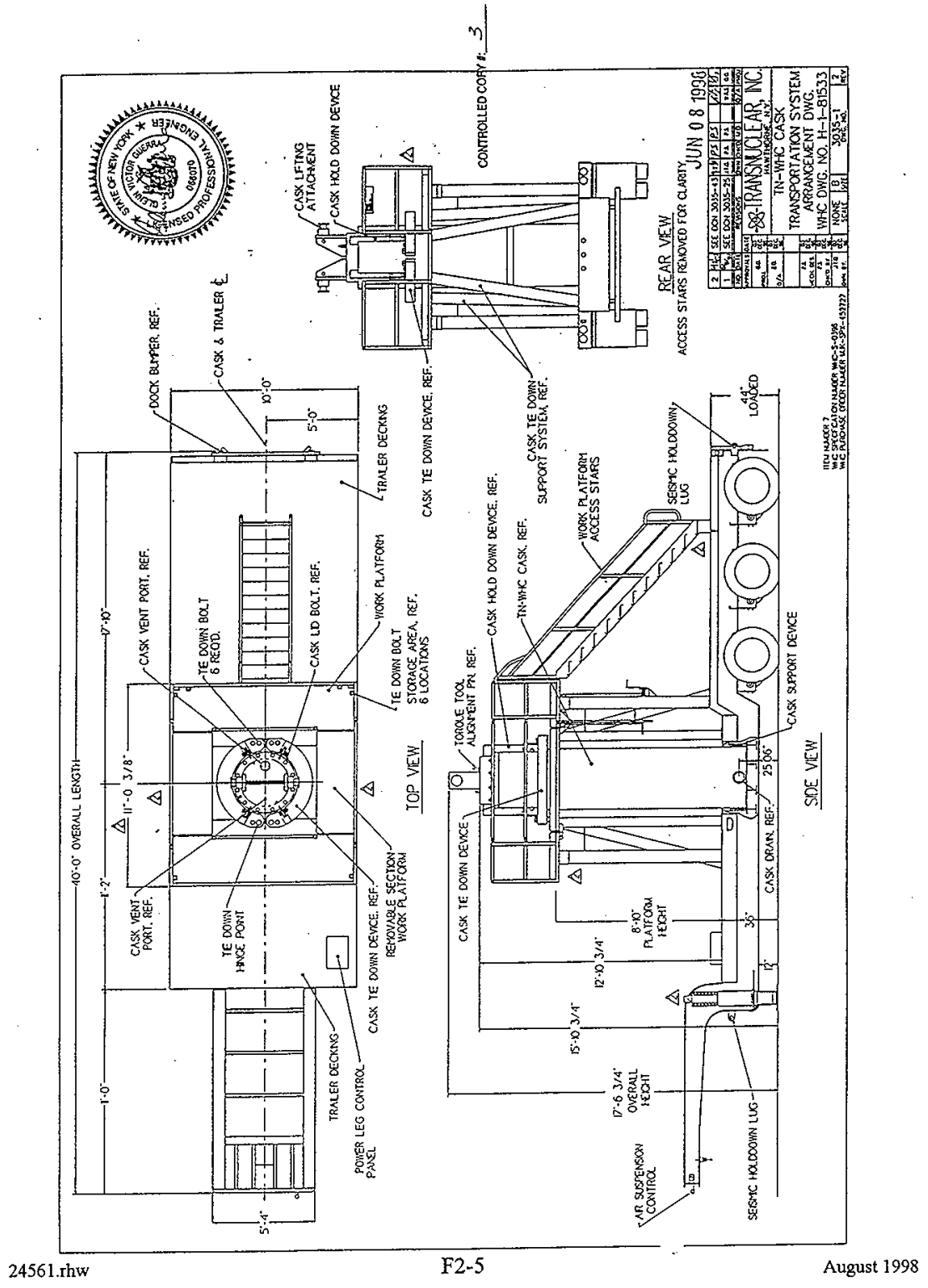


Figure 2-6. $\mathrm{MCO}$ and $\mathrm{MCO}$ Baskets

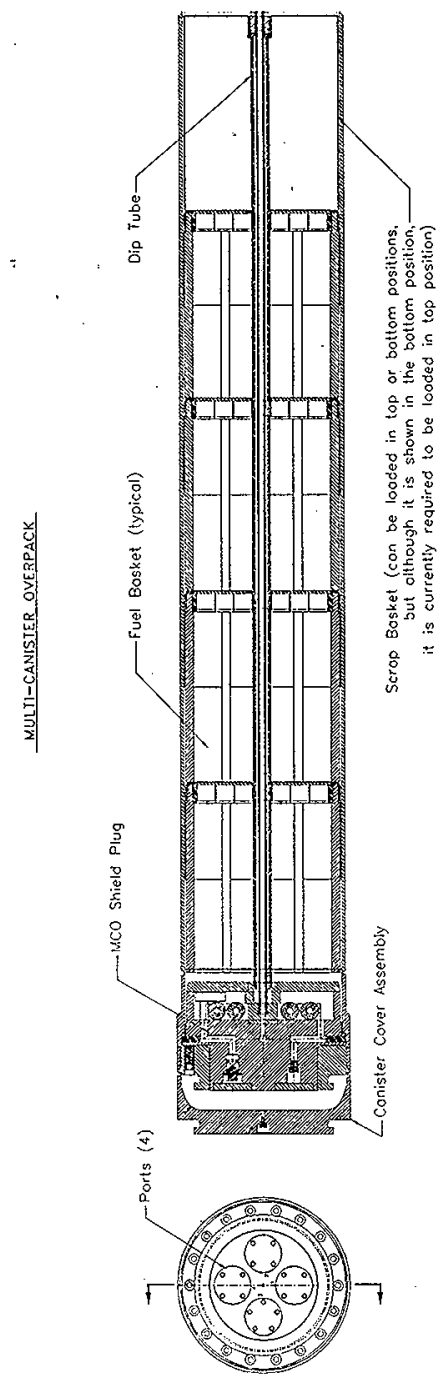


Figure 2-7. MCO Shield Plug.
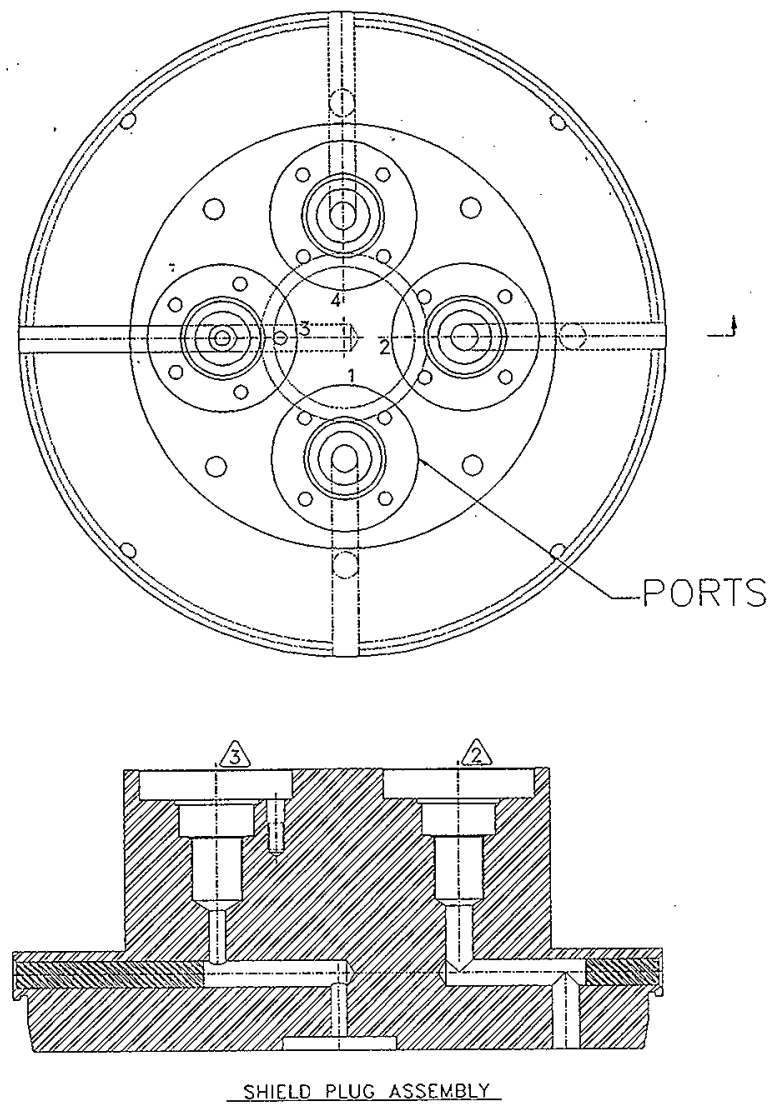
Figure 2-8. Mast and Grapple.

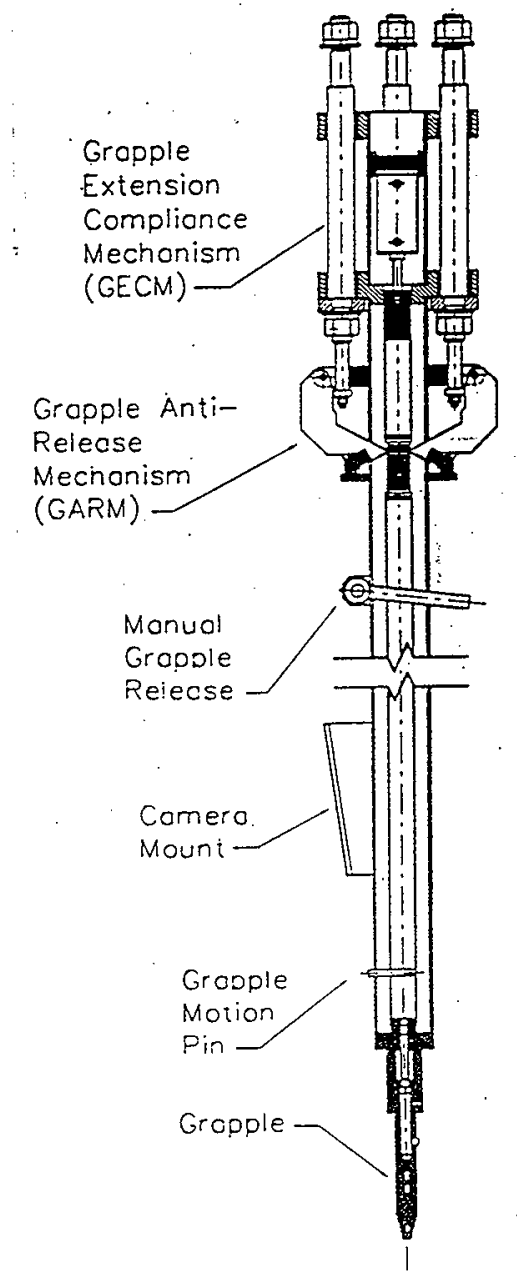


HNF-2456, Rev. 0

\subsection{HAZARD AND ACCDENT ANALYSES}

\subsection{INTRODUCTION}

This chapter accomplishes the following:

- Defines the processes used to identify and assess potential hazards associated with the cask loadout process at the K Basins, the cask loadout system (CLS) installation, and operational activities, including the interfacing structures, systems, and components (SSC)

- Presents the results of the hazard identification and assessment process

- Presents the results of abnormal events and design basis accidents (DBA) that are representative of the potential hazardous conditions associated with each system's installation and operation.

The analyses presented in this chapter are for the unmitigated cases. Based on the potential consequences of the event, requirements were developed for the equipment to prevent or mitigate the consequences. The resulting safety equipment design features and controls are identified in Chapter 4.

\subsection{REQUTREMENTS}

The hazard and accident analyses processes used for the cask-loading operations were performed to comply with the U.S. Department of Energy orders, federal and state regulations, and standards found in HNF-SD-SNF-RD-001, SNF $K$ Basins and Cold Vaculum Drying Standards/Requirements Identification Document (Watson 1998).

HNF-SD-SNF-RD-001 identifies the set of requirements necessary and sufficient to adequately protect workers, the public, and the environment.

The specific standards and requirements that apply to equipment within the scope of cask loadout activities are found in WHC-S-0396, Performance Specification for TN-WHC Cask and Transportation System (Kee 1995), and WHC-S-0546, Performance Specification for SNF $K$ East and $K$ West MCO Loading System (Brisbin 1997a). The standards and requirements that apply to the multi-canister overpack (MCO) are found in HNF-S-0426, Performance Specification for the Spent Nuclear Fuel Project Multi-Canister Overpack (DESH 1998a). 


\section{U.S. Nuclear Regulatory Commission Rules and Guidance}

The Spent Nuclear Fuel (SNF) Project has committed to achieve "nuclear safety equivalency" to comparable U.S. Nuclear Regulatory Commission (NRC) licensed facilities. Facilities were evaluated to identify any additional NRC requirements needed in combination with the existing and applicable DOE requirements to establish nuclear safety equivalency.

The only NRC equivalency requirement identified that applies to the cask loadout process at the $\mathrm{K}$ Basins (Garvin 1997) is incorporating a criticality safety value of 0.95 for $\mathbf{k}_{\text {eff. }}$ (This requirement applies at the point the spent fuel, in an MCO basket, is placed in an MCO.) The requirement is incorporated into the CLS by its subsystem, the MCO loading system (MLS), and analyzed in the MLS criticality safety evaluation report (CSER) (Kessler 1998).

\subsection{HAZARD ANALYSIS}

This section describes the hazard identification and evaluation performed for installing and operating the CLS equipment. A number of hazards identification and evaluation methods were used throughout the design effort. Hazards and their associated safety requirements for the MCO and the cask transportation system (CTS) are documented in their technical specifications (Kee 1995 and DESH 1998a) or associated safety documentation (Edwards 1998 and Lorenz 1997). The MCO and CTS were evaluated for hazards in this safety analysis document (SAD) to the extent that they affect or are affected by cask loadout operations. This document does not address the hazards associated with phenomena inside closed MCOs or transportation to the Cold Vacuum Drying Facility.

The safety analysis considers releases of radioactive and hazardous material during normal, upset (abnormal but anticipated), and accident (unlikely or extremely unlikely) conditions. A graded selection process was used to identify accidents with the potential to cause unacceptable consequences. These accidents were further analyzed and a set of cost-effective controls was selected to ensure that the facility releases are acceptable during construction, operation, and decommissioning.

This section presents the method used to perform the hazard analysis and identifies the accidents selected for more comprehensive analysis. Onsite and offsite dose consequences for radiological material are calculated as applicable. The consequences were compared with the established risk evaluation guidelines and limits (Table 3-1) to evaluate the risk level and the need for prevention or mitigation. The radiological risk guidelines and limits are given in terms of whole body effective dose equivalent (EDE) (rem) for the potential accidents that could expose the onsite and offsite (public) receptors. The risk evaluation guidelines also are defined in terms of qualitative annual frequency of occurrence. Radiological hazards in the SNF Project bound toxicological hazards (FDNW 1998).

During the conceptual design phase, the design team used hazards identification checklists to identify potential hazards affecting design development. With the design approximately 20 percent complete, design authorities from the SNF subprojects met to review the SNF process 
flow to identify any additional potential drop accidents. The design authorities formally presented the travel paths of the Cask-MCO in their areas of responsibility. All load and lift paths were discussed and additional drop analyses were identified.

A formal hazards and operability study (HAZOPS) was performed. Design basis accidents and beyond design basis accidents were identified through a binning process that considered the type of accident and the severity of unprevented or unmitigated consequences. Accidents were sorted by category (i.e., Cask-MCO delivery, drop, fuel burn) and listed in descending order of seriousness. Seriousness reflects unprevented and unmitigated frequency and consequence under each accident category.

Table 3-1. Risk Evaluation Guidelines and Limits. ${ }^{\text {. }}$

\begin{tabular}{|l|c|c|c|}
\hline \multirow{2}{*}{ Event frequency category } & \multirow{2}{*}{$\begin{array}{c}\text { Event frequency } \\
\left(\mathrm{yr}^{-1}\right)\end{array}$} & \multicolumn{2}{|c|}{ Radiological dose limits (rem) } \\
\cline { 3 - 4 } & $0.1-10^{-2}$ & Onsite & Offsite \\
\hline Anticipated & $10^{-2}-10^{-4}$ & 10 & 0.5 \\
\hline Unlikely & $10^{-4}-10^{-6}$ & 25 & 5 \\
\hline Extremely unlikely & & 10 & 5 \\
\hline
\end{tabular}

${ }^{2} T$ These guidelines are to be applied as step-functions. Guidelines are from Sellers, E. D., 1997a, Risk Evaluation Guidelines (REG) to Ensure Inherently Safe Designs, RL-97-SFD-172, transmitted under letter 97-SFD-172 to H. J. Hatch, Fluor Daniel Hanford, Inc., dated August 26, 1997, U.S. Department of Energy, Richland Operations Office, Richland, Washington.

Lastly, a hazards and safety assessment was performed on each piece of equipment to be installed to determine the following:

- The impact of the change to the facility

- The potential impact on the authorization bases

- Potential installation safety concerns.

The hazards and safety assessment was performed in accordance with DOE Order 5480.21, Unreviewed Safety Questions. Results of the checklist are provided in Appendix 3B and in the hazards/safety assessment report (Webb 1998a).

Fire hazards are covered by the K Basins fire hazard analysis report (Myott 1998). Criticality safety analysis is documented in the MLS CSER (Kessler 1998). The associated criticality accident scenarios are covered in Chapter 6 . 


\subsubsection{Method}

This section presents the method used to identify, characterize, and evaluate the hazards associated with CLS equipment installation and operation in the cask loadout process. The American Institute of Chemical Engineers Guidelines for Hazard Evaluation Procedures (AIChE 1992) defines a hazard as an inherent physical or chemical characteristic that may cause harm to people, property, or the environment or a combination of a hazardous material, operating environment, and unplanned event that might lead to an accident. Both definitions are considered when choosing hazard evaluation methods. The hazard analysis was performed in accordance with DOE-STD-3009-94, Preparation Guide for U.S. Department of Energy Nonreactor Nuclear Facility Safety Analysis Reports, and implements the requirements of DOE Order 5480.23, Nuclear Safety Analysis Reports.

Potential hazards (combinations of a hazardous material, operating environment, and unplanned event) have been identified and qualitatively evaluated using the following processes:

- A hazardous material and energy sources checklist

- Hazards activity checklists

- $\quad$ Preliminary hazards analysis (PHA) process for equipment installation

- HAZOPS

- Specific design and criticality analyses.

3.3.1.1 Hazard Identification Method. Hazard identification is the process of finding material, system, process, and facility characteristics with the potential to initiate accidents having undesirable consequences. This section describes the methods used to identify potential hazards for the installation and operation of the CLS equipment for the scope of the cask loadout and MCO loading process. Maintenance requirements for the cask loadout equipment are low and the small amount of maintenance performed can be considered to present only standard industrial hazards (Brisbin 1997b).

The process identified no toxicological hazards associated with the cask loadout and MCO loading process. This verified that toxicological hazards are bounded by radiological hazards (FDNW 1998). Thus, only radiological hazards were analyzed.

3.3.1.1.1 Hazardous Material/Energy Source Checklist. To ensure that accidentinitiating events potentially resulting from intrinsic hazards (physical or chemical characteristics that might harm people) were not omitted, a hazardous material and energy source checklist was used to identify intrinsic hazard sources that might exist during operation of the CLS equipment. Table 3-2 identifies the general grouping of hazards from the checklist. Appendix 3A, Tables 3A-1 through $3 \mathrm{~A}-3$ provide the results of the review.

3.3.1.1.2 Hazards and Operability Study. The hazard and accident analysis process is a systematic, form-driven, approach in which hazards within a given scope of operation are identified. A HAZOPS, performed by a multi-discipline team of experienced personnel representing organizations responsible for various aspects of the CTS, CLS, and K Basins was the primary process used to identify and evaluate hazards for the cask loadout and MCO loading 
operations. Hazards covered by an institutional safety program (industrial safety, industrial hygiene, fire protection, radiation protection, etc.) were identified in the checklist phase and excluded from further evaluation. The following factors were inputs for the study:

- $\quad$ Equipment specifications

- $\quad$ Process and design descriptions (including operational process flow diagrams)

- $\quad$ System drawings

- Input from the individual design authorities.

Table 3-2. Hazards Analysis Checklist.

\begin{tabular}{|l|}
\hline \multicolumn{1}{|c|}{ Hazards } \\
\hline Electrical \\
Thermal \\
Friction \\
Corrosives \\
Kinetic, rotational \\
Kinetic, linear \\
Mass, gravity, height \\
Pressure-volume \\
Explosives, pyrophorics \\
Nuclear criticality \\
Flammable materials \\
Hazardous materials \\
Ionizing radiation sources \\
External events \\
Vehicles in motion (outside the facility) \\
Natural phenomena \\
\hline
\end{tabular}

The detailed cask loadout process flow of operations is included in the cask loadout system technical manual (Praga and Pajunen 1998). The HAZOPS team's collective expertise was used to postulate potential hazardous conditions and associated accident scenarios for each operation in the cask loadout and MCO loading processes. Hazard identification for the Cask-MCO loading process was based on an examination of the three major loading operations activities (nodes): cask installation, $\mathrm{MCO}$ loading, and cask removal.

The scope of operational activities evaluated by the HAZOPS included the cask loadout and MCO loading operations bounded by the following:

1. Receipt and departure of the Cask-MCO tractor-trailer to or from a basin

2. Cask unloading/loading activities

3. Cask installation in and removal from the basin 
4. Acceptance of MCO baskets from the Fuel Retrieval Subproject (FRS)

5. Transfer and loading of MCO baskets.

The accident scenarios identified by this study were based on considerations of plant equipment and facility layout; operating environment; operating activities, including testing; and interfaces among system components and their intrinsic hazards.

Qualitative frequency and consequence assessment codes for these potential accident scenarios were identified. Engineered design features and administrative controls were not considered in determining a raw hazard severity value. Engineered design features and administrative controls then were evaluated to identify their importance in reducing hazard severity levels. Finally, the results of the HAZOPS were used to ensure that adequate measures are taken to eliminate, control, or mitigate the identified hazards. Safety-class and safetysignificant SSC were identified by the hazard and accident analysis process. The detailed hazards evaluation methodology is described in Section 3.3.1.2.

Criticality accidents were evaluated separately in the MLS CSER (Kessler 1998); Chapter 6 contains the results. A detailed review of the Fire Hazard Analysis (FHA) for the $K$-Basins Facilities at the $100 \mathrm{~K}$ Area (Myott 1998) determined the adequacy of coverage for fire hazards associated with cask-loading operations. Therefore, fire hazards were not covered in the HAZOPS.

3.3.1.1.3 Hazard Activity Checklist. A hazard activity checklist was used to ensure that accident-initiating events potentially resulting from intrinsic hazards during installation activities were not omitted (DESH 1997). Appendix 3B provides the results of this review. The CTS was not evaluated by this process because it does not include any installed equipment (Webb 1998a).

All CLS equipment to be installed in the basin has been evaluated for its potential to be dropped during installation and for the drop to cause basin perforation and was found to be acceptable. The following equipment required analysis to determine if the consequences of dropping it during installation are acceptable:

- $\quad$ MLS shuttle (Chenault 1998a)

- $\quad$ MLS gantry with mast (Chenault 1998b)

- Immersion pail support structure (Sellers 1997b, 1997c)

- Immersion pail (Chenault 1997, 1998c).

3.3.1.2 Hazards Evaluation Methodology. Hazards evaluation uses qualitative techniques to analyze the significance of the hazardous situations associated with an activity. This evaluation was performed as part of the HAZOPS in accordance with DOE-STD-3009-94, Preparation Guide for U.S. Department of Energy Nonreactor Nuclear Facility Safety Analysis Reports, and DOE-EM-STD-5502-94, Hazard Baseline Documentation, and identified the following:

- Hazard and location, taken from the checklist

- $\quad$ Specific event number 
HNF-2456, Rev. 0

- Event category

- Postulated event description and possible consequences

- Receptor of consequences

- Estimated frequency assessment code of scenario with and without prevention (Table 3-3)

- Credited prevention engineering and administrative features that contribute lower frequency

- Consequence assessment code of scenario with and without mitigation (Table 3-4)

- Credited mitigation engineering and administrative features that lessen consequences

- Defense-in-depth engineered features and administrative controls

- Hazard severity bin number (a function of scenario frequency [Table 3-3] and assessment code [Table 3-4], and found in Figures 3-1, 3-2, and 3-3).

Determinations are made both with and without prevention and mitigation.

The detailed hazard analysis summary table for this evaluation is provided in Appendix 3A, Table 3A-4.

Table 3-3. General Criteria for Frequency Assessment.

\begin{tabular}{|c|c|c|}
\hline $\begin{array}{c}\text { Frequency } \\
\text { assessment code }\end{array}$ & $\begin{array}{c}\text { Estimated annual } \\
\text { frequency }\end{array}$ & $\begin{array}{c}\text { Description } \\
\text { (based on the initiating events postulated, the } \\
\text { hazardous condition) }\end{array}$ \\
\hline F3 & $\begin{array}{c}\text { Anticipated: } \\
10^{-1} / \mathrm{yr}>\mathrm{F} 3 \geq 10^{-2} / \mathrm{yr}\end{array}$ & $\begin{array}{l}\text { Has occurred or is likely to occur during the } \\
\text { lifetime of the facility }\end{array}$ \\
\hline F2 & $\begin{array}{c}\text { Unlikely: } \\
10^{-2} / \mathrm{yr}>\mathrm{F} 2 \geq 10^{-4} / \mathrm{yr}\end{array}$ & $\begin{array}{l}\text { Is foreseable, but unlikely to occur during the } \\
\text { lifetime of the facility }\end{array}$ \\
\hline F1 & $\begin{array}{c}\text { Extremely unlikely: } \\
10^{-4} / \mathrm{yr}>\mathrm{F} 1 \geq 10^{-6} / \mathrm{yr}\end{array}$ & $\begin{array}{l}\text { Is perhaps possible, but extremely unlikely to } \\
\text { occur during the lifetime of the facility }\end{array}$ \\
\hline F0 & $\begin{array}{c}\text { Beyond extremely unlikely: } \\
10^{-6} / \mathrm{yr}>\mathrm{F} 0\end{array}$ & $\begin{array}{l}\text { Is considered too improbable to warrant further } \\
\text { consideration }\end{array}$ \\
\hline
\end{tabular}


Table 3-4. General Criteria for Consequence Assessment.

\begin{tabular}{|c|l|}
\hline $\begin{array}{c}\text { Consequence } \\
\text { assessment code }\end{array}$ & \multicolumn{1}{c|}{\begin{tabular}{c}
\multicolumn{1}{c|}{ Description } \\
(based on the MAR and initiating events postulated:
\end{tabular}} \\
\hline S3 & $\begin{array}{l}\text { Sufficient material and energy are available to cause a high or moderate } \\
\text { impact to the maximum offsite individual. }\end{array}$ \\
\hline S2 & $\begin{array}{l}\text { Sufficient material and energy are available to cause a high or moderate } \\
\text { impact to the maximum onsite individual. }\end{array}$ \\
\hline S0 & $\begin{array}{l}\text { Sufficient material and energy are available to cause an industrial } \\
\text { injury, radiological dose, or chemical exposure to one or more facility } \\
\text { workers. }\end{array}$ \\
\hline & $\begin{array}{l}\text { Sufficient material and energy are not available to adversely impact } \\
\text { facility workers. }\end{array}$ \\
\hline
\end{tabular}

$\mathrm{MAR}=$ material at risk

The items in the "engineered safety feature" column of Table 3A-4 are candidates for designation as safety-class or safety-significant SSCs, depending on the consequence severity. The "administrative features" column lists administrative controls that might be used to prevent or mitigate the consequences of the hazardous condition. These features are candidates for technical safety requirements (TSR).

\subsubsection{Hazard Analysis Results}

3.3.2.1 Hazard Identification. Appendix 3A, Tables 3A-1 through 3A-3, and Appendix 3B list the intrinsic hazards related to the CLS equipment installation and operation. These intrinsic hazards were used to facilitate the identification of specific hazards associated with the scope of operations. Appendix 3A, Tables 3A-1 through 3A-3, list the hazards identified during the HAZOPS for the three major loading operations (cask installation, MCO loading, and cask removal, respectively). Appendix $3 \mathrm{~B}$ lists the hazards identified by the preliminary safety analysis that supports equipment installation. Tables 3-5 and 3-6 summarize the hazard and operability items considered.

3.3.2.2 Hazard Classification. The hazard classification for $\mathrm{K}$ Basins fuel storage in the $100 \mathrm{~K}$ Area of the Hanford Site has been established and documented in WHC-SD-SNF-HC-001, $K$ Basin Fuel Encapsulation and Storage Hazard Categorization (Porten 1994). This hazard categorization addressed the potential for release of radioactive and nonradioactive hazardous material located in the $\mathbf{K}$ Basins and their supporting facilities. This analysis covered normal $\mathrm{K}$ Basin fuel storage and handling operations, fuel encapsulation, and canister clean-up and disposal.

This hazards categorization was performed using the method and criteria from Hazard Categorization and Accident Analysis Techniques for Compliance with DOE Order 5480.23, Nuclear Safety Analysis Reports (DOE-STD-1027-92). Porten (1994) determined that the 
$\mathrm{K}$ Basins should be considered a hazard category 2 facility (i.e., a facility in which the "Hazard Analysis shows the potential for significant onsite consequences" [DOE-STD-1027-92]).

Table 3-5. Summary of Category S2* and S3 Hazard and Operability Items. (2 sheets)

\begin{tabular}{|c|c|c|}
\hline $\begin{array}{l}\text { Consequence } \\
\text { category/ } \\
\text { estimated } \\
\text { frequency** }\end{array}$ & $\begin{array}{l}\text { Process } \\
\text { parameter } \\
\text { (node) }\end{array}$ & $\begin{array}{l}\text { Description } \\
\text { (cross-reference information) }\end{array}$ \\
\hline $\mathrm{S} 3 / \mathrm{F} 2$ & $\mathrm{CI} / \mathrm{CR}$ & $\begin{array}{l}\text { Transfer bay crane fails during cask installation or removal. Cask is dropped from a } \\
\text { height just above the south loadout pit curb onto the immersion pail support structure } \\
\text { (CI-G-3d, CR-G-3b)*** } \\
\text { DBA 3.4.2.1 MCO/Cask Drop into the South Loadout Pit }\end{array}$ \\
\hline S3/F2 & CI/CR & $\begin{array}{l}\text { Transfer bay crane or locking pins fail during cask installation or removal. Immersion } \\
\text { pail and Cask-MCO is dropped from top IPSS height onto the IPSS bottom plate. } \\
\text { (CI-G-3e, CR-G-3a)*** } \\
\text { DBA 3.4.2.1 MCO/Cask Drop into the South Loadout Pit }\end{array}$ \\
\hline S3/F2 & $\mathrm{CI} / \mathrm{CR}$ & $\begin{array}{l}\text { Transfer bay crane fails during cask installation or removal. Cask impacts south } \\
\text { Joadout pit curb. (CI-G-3b, Cl-G-3c, CR-G-3c, CR-G-3d, I-F-5b, CR-F-Sbl)*** } \\
\text { DBA 3.4.2.2 MCO/Cask Drop Impacts South Loadout Pit Curb }\end{array}$ \\
\hline $\mathrm{S} 3 / \mathrm{F} 1$ & $\mathrm{ML}$ & $\begin{array}{l}\text { Basket is raised out of water during MCO loading process. (ML-G-3b2)*** } \\
\text { DBA 3.4.2.3 MCO Basket Overlift }\end{array}$ \\
\hline $\mathrm{S} 3 / \mathrm{F} 2$ & ML. & $\begin{array}{l}\text { MCO basket is dropped during MCO loading. (ML-G-3a)*** } \\
\text { DBA 3.4.2.4 MCO Basket Drop }\end{array}$ \\
\hline S3/F2 & $\mathrm{CI} / \mathrm{ML} / \mathrm{CR}$ & $\begin{array}{l}\text { A design basis earthquake occurs. (CI-R-1a, ML-R-1c, CR-R-1a)*** } \\
\text { DBA 3.4.2.5 Seismic Event }\end{array}$ \\
\hline $\mathrm{S} 3 / \mathrm{F} 2$ & $\mathrm{CI}$ & $\begin{array}{l}\text { While delivering an Cask-MCO, transport trailer backs into the basin exceeding the } \\
\text { speed and strikes building (bumper), which potentially damages basin. (CI-F-1a)*** } \\
\text { BDBA 3.4.3.1 Uncontrolled Transport Trailer Accident During MCO/Cask } \\
\text { Delivery }\end{array}$ \\
\hline $\mathrm{S} 3 / \mathrm{F} 2$ & CI & $\begin{array}{l}\text { While delivering an Cask-MCO, transport trailer backs into the south loadout pit } \\
\text { curb. (CI-F-1c)*** } \\
\text { BDBA 3.4.3.1 Uncontrolled Transport Trailer Accident During MCO/Cask } \\
\text { Delivery }\end{array}$ \\
\hline $\mathrm{S} 3 / \mathrm{F} 2$ & $\mathrm{CI}$ & $\begin{array}{l}\text { While delivering an Cask-MCO, transport trailer impacts gantry structure. } \\
\text { (Cl-F-1b)*** } \\
\text { BDBA 3.4.3.1 Uncontrolled Transport Trailer Accident During MCO/Cask } \\
\text { Delivery }\end{array}$ \\
\hline $\mathrm{S} 3 / \mathrm{Fl}$ & $\mathrm{ML}$ & $\begin{array}{l}\text { A design basis earthquake occurs while a scrap basket is in the highest loading } \\
\text { position and the general service gantry fails in this position. As a result of basin water } \\
\text { drainage, the basket is exposed to air. (ML-G-3c, ML-R-1b)*** } \\
\text { BDBA 3.4.3.2 Seismic Event with Gantry Lift of MCO Basket }\end{array}$ \\
\hline
\end{tabular}


Table 3-5. Summary of Category S2* and S3 Hazard and Operability Items. (2 sheets)

\begin{tabular}{|c|c|c|}
\hline $\begin{array}{l}\text { Consequence } \\
\text { category/ } \\
\text { estimated } \\
\text { frequency** }\end{array}$ & $\begin{array}{l}\text { Process } \\
\text { parameter } \\
\text { (node) }\end{array}$ & $\begin{array}{c}\text { Description } \\
\text { (cross-reference information) }\end{array}$ \\
\hline $\mathrm{S} 3 / \mathrm{F} 2$ & CR & $\begin{array}{l}\text { Not transporting the MCO to the CVDF within the specified transport window, } \\
\text { potentially resulting in decay heat buildup in MCO, MCO pressurization if valve is } \\
\text { not open, or runaway thermal reaction. MCO topical and SARP provide the accident } \\
\text { analysis for this accident. (CR-B-7)*** } \\
\text { Pajunen, A.L., 1998, Spent Nuclear Fuel Project Product Specification, } \\
\text { HNF-SD-SNF-OCD-001, Rev. 2, Cogema for Fluor Daniel Hanford, Inc., Richland, } \\
\text { Washington. (This requirement will be incorporated into the TSR). }\end{array}$ \\
\hline \$3/F3 & ML & $\begin{array}{l}\text { The pressure valves in the MCO shield plug are closed during transport to the CVDF } \\
\text { resulting in pressurization of MCO and hydrogen buildup. MCO topical and SARP } \\
\text { provide the design evaluation for this accident. (ML-H-6)*** } \\
\text { Edwards, W. S., 1998, Safety Analysis Report for Packaging (Onsite) Multi-Canister } \\
\text { Overpack Cask, HNF-SD-TP-SARP-017, Rev. 1, draft, Waste Management Federal } \\
\text { Services, Inc., Northwest Division, for Fluor Daniel Hanford, Inc., Richland, } \\
\text { Washington. (This requirement will be incorporated into the TSR.) }\end{array}$ \\
\hline $\mathrm{S} 3 / \mathrm{F} 2$ & ML & $\begin{array}{l}\text { Fuel is now at a new maximum elevation and allows less time for response in the } \\
\text { event of basin drainage (ML-N-3)*** } \\
\text { (To be incorporated by } K \text { Basins } S A R \text { revision) }\end{array}$ \\
\hline
\end{tabular}

* No S2 hazard and operability items were identified

**Unprevented and unmitigated

***Unique event number as found in Tables $3 \mathrm{~A}-1$ through $3 \mathrm{~A}-4$

$\begin{array}{ll}\text { CI } & \text { Cask installation. } \\ \text { CR } & =\text { Cask removal. } \\ \text { IPSS } & \text { Immersion pail support structure. } \\ \text { CVDF } & =\text { Cold vacuum drying facility. } \\ \text { MCO } & \text { Multi-canister overpack. } \\ \text { ML } & =\text { MCO loading. } \\ \text { SAR } & \text { Safety analysis report. }\end{array}$


Table 3-6. Summary of Category S1 Hazards and Operability Items. (2 sheets)

\begin{tabular}{|c|c|c|}
\hline $\begin{array}{l}\text { Consequence } \\
\text { category/estimated } \\
\text { frequency* }\end{array}$ & $\begin{array}{l}\text { Process } \\
\text { parameter } \\
\text { (node) }\end{array}$ & $\begin{array}{l}\text { Description } \\
\text { (cross reference information) }{ }^{* *}\end{array}$ \\
\hline S1/F3 & $\begin{array}{l}\text { MCO } \\
\text { loading } \\
\text { (ML) }\end{array}$ & $\begin{array}{l}\text { During installation of MCO shield plug, the process dip tube does not seat } \\
\text { correctly. This causes the potential for additional dose to the facility worker. } \\
\text { (ML-G-3d)** }\end{array}$ \\
\hline $\mathrm{S} 1 / \mathrm{F} 2$ & $\mathrm{Cl} / \mathrm{CR}$ & $\begin{array}{l}\text { Cask-MCO or transport trailer impacts south loadout pit curb and causes a } \\
\text { partial crack in the south loadout pit wall that drains } 0.9 \mathrm{~m}(3 \mathrm{ft} \text { ) of water. } \\
\text { As a result of some water draining, less water is available to shield the fuel, } \\
\text { causing the potential for additional dose to the facility worker. (CI-F-lc, } \\
\text { CI-F-5b2, CI-F-5b2)** }\end{array}$ \\
\hline $\mathrm{S} 1 / \mathrm{F} 2$ & $\mathrm{CI} / \mathrm{CR}$ & $\begin{array}{l}\text { Trailer jacks fail causing Cask-MCO to strike and potentially kill onsite } \\
\text { facility worker. (CI-G-9, CR-G-9)** }\end{array}$ \\
\hline $\mathrm{S} 1 / \mathrm{F} 1$ & CI & $\begin{array}{l}\text { Immersion pail seal is overinflated during installation causing potential for } \\
\text { additional dose to the facility worker. (CI-H-11)** }\end{array}$ \\
\hline $\mathrm{S} 1 / \mathrm{F} 1$ & ML & $\begin{array}{l}\text { Basket is raised too high while loading, but maintainied below the water line, } \\
\text { causing the potential for additional dose to the facility worker. (ML-G-3bI, } \\
\text { ML-N-3a)** }\end{array}$ \\
\hline $\mathrm{S} 1 / \mathrm{F} 1$ & $\mathrm{CR}$ & $\begin{array}{l}\text { The MCO shield plug is not installed before loaded Cask-MCO is lifted. } \\
\text { This causes the potential for additional dose to the facility worker. (CR-N-3, } \\
\text { CR-N-5)** }\end{array}$ \\
\hline
\end{tabular}

- Unprevented/unmitigated

** Unique event number as found in Tables $3 \mathrm{~A}-1$ through $3 \mathrm{~A}-4$

$\mathrm{CI} \quad=$ Cask installation.

$\mathrm{CR} \quad=$ Cask removal.

$\mathrm{MCO}=$ Multi-canister overpack.

MI = MCO loading.

Cask loadout and MCO loading operations are similar to those covered in the K Basin hazard analysis (Porten and Crowe 1994). Neither operation changes the hazard category of the $\mathrm{K}$ Basins because neither the maximum amount of fuel stored in the basins nor the form of the fuel is changed.

CLS operations will not add any toxic substances. The toxicological risk from accidents associated with the fuel are bounded by the radiological risk (FDNW 1998).

3.3.2.3 Hazard Evaluation. A HAZOPS was performed to accomplish the following:

- Define the events' causes and identify their consequences 
- Identify possible engineered safety features that could prevent the hazards or mitigate their consequences

- Identify possible administrative features that could prevent the hazards or mitigate their consequences

- Define the material at risk (MAR).

The HAZOPS (Webb 1998b) identified standard industrial hazards and eliminated them from further review. All other hazards were evaluated for potential accident scenarios. Initiating events were listed and the characterization information identified for the energy sources related to the initiating event. The characterized hazards were entered in the hazard analysis tables by node designation (i.e., cask installation, MCO loading, and cask removal). Each hazardous condition was then identified and recorded along with the potential accidents arising from the presence of the hazard, potential causes and consequences of the hazardous condition, existing design features to prevent the accident or mitigate the consequences, administrative features planned to prevent the accident condition or mitigate the consequences, and qualitative estimates of the frequency and consequences of the accident condition.

The hazard identification groupings described in Section 3.3.1.1 provide systematic evaluation of the hazards based on common release phenomena. The hazards evaluation provided in Section 3.3.1.2 considers the potential impact of the hazard to the offsite public, onsite collocated worker, and the facility worker. The hazard analysis also examines the potential for environmental contamination and lists those preventive or mitigative features that already are part of the design.

The HAZOPS assumed that the fuel within a loaded MCO filled with water will not spontaneously burn. This assumption has been validated by HNF-2786 (Duncan 1998).

3.3.2.3.1 Planned Design and Operational Safety Improvements. The CLS is a planned improvement for the $\mathrm{K}$ Basins to facilitate removal of the SNF. The CLS design incorporates many design features intended to provide protection from hazardous conditions. No design or operational improvements are planned for the CLS equipment.

3.3.2.3.2 Defense-in-Depth. Defense-in-depth consists of multiple features (equipment and administrative) relied on for accident prevention or mitigation to a degree proportional to the hazard potential (likelihood and consequences). Defense-in-depth includes administrative programs to ensure that features continue to be available for accident prevention or mitigation and administrative programs that promulgate a particular set of safety practices. In Preparation Guide for U.S. Department of Energy Nonreactor Nuclear Facility Safety Analysis Reports, DOE-STD-3009-94, defense-in-depth includes identifying safety-class SSCs and other items needing TSR coverage.

In conjunction with the facility design and existing administrative controls, the CLS equipment design is the most important component of the defense-in-depth strategy for protecting 
workers, the public, and the environment. Specific design features that implement defense in depth include the SSCs with the following functions:

- Barriers to uncontrolled hazardous material or energy release and heavy loads

- Geometric controls to prevent criticality events for MCO loading

- Administrative controls implemented through the $\mathrm{K}$ Basin criticality prevention program to prevent criticality events during fuel handling activities

- Water cover over fuel to prevent uncontrolled release of radioactive material

- Equipment that prevents uncontrolled drops of MCO baskets (grapple anti-release mechanism on gantry)

- Structural design of lifting components

- Structural component design preventing dropped loads from perforating the safety-class basin boundary

- Area radiation monitor system that provides an indication of increasing dose level to allow corrective actions to minimize worker exposure.

The CLS safety equipment list identifies the items that have been designated as safety class or safety significant. Table 3-7 lsits the safety-class and safety-significant SSCs, along with an indication of the safety concern. Table 3-8 lists the non-safety (general-service) items used for defense in depth.

Table 3-7. CLS Safety Equipment List. ${ }^{a}$

\begin{tabular}{|l|c|}
\hline \multicolumn{1}{|c|}{ System/subsystem } & Safety classification \\
\hline Immersion pail support structure (prevents penetration of basin boundary) & Safety class \\
\hline Immersion pail (prevents penetration of basin boundary) & Safety class \\
\hline $\begin{array}{l}\text { MLS gantry (prevents overlift of MCO basket and subsequent fuel burn or } \\
\text { aerodynamic release with airborne radioactive material release, limits MCO } \\
\text { basket drop height, prevents falling into south loadout pit during seismic } \\
\text { event) }\end{array}$ & Safety class \\
\hline $\begin{array}{l}\text { MLS shuttle (prevent criticality by prohibiting MCO baskets from being } \\
\text { loaded into nonqualified queue positions and prevents penetrations of the } \\
\text { basin boundary) }\end{array}$ & Safety class \\
\hline
\end{tabular}

'See discussion of safety-class features in Chapter 4.

${ }^{b}$ All equipment on this list was procured with a lesser safely designation than is currently required and will undergo a safety upgrades process to verify that safety requirements are met before installation/operation.

$\mathrm{MCO}=$ multi-canister overpack.

MLS = MCO loading system. 
Defense-in-depth also is linked to the following overall safety management programs that directly control operations at the $\mathrm{K}$ Basins.

- Procedural restrictions or limits imposed

- Manual monitoring of critical parameters

- Equipment support functions

- Responses or actions counted on to limit abnormal conditions, accident progression, or potential personnel exposure.

Specific administrative controls that implement defense in depth and are currently being used include the following:

- Controlled entry for vehicles

- $\quad$ Procedures to prevent criticality events during fuel handling activities

- Controlled lifting and moving heavy loads

- Transfer bay operational procedures

- Qualifications of crane operators

- Recovery plans

- Risk assessment of activities

- Radiological control procedures.

The specific general-service SSCs associated with the loading operations are identified in Table 3-8.

On an activity basis, defense in depth includes job hazard and safety analysis for activities, prejob safety meetings for non-routine or infrequent tasks, worker training and qualification, procedures, good housekeeping, and a feedback and lessons-learned program.

Table 3-8. CLS Defense-In-Depth Equipment List.

\begin{tabular}{|l|c|}
\hline \multicolumn{1}{|c|}{ System/subsystem } & Safety classification \\
\hline MLS control system & General service \\
\hline MLS observation cameras & General service \\
\hline Grapple anti-release mechanism & General service \\
\hline
\end{tabular}

MLS = MCO loading system.

3.3.2.3.3 Worker Safety. Worker safety for the installation and operation of the CLS equipment is ensured by a combination of design safety features, shielding, and institutional practices. Equipment-lifting features, critical lift procedures, and installation procedures will provide for safe installation. The equipment is designed to store and handle radioactive SNF in a configuration and manner that protects workers, the public, and the environment. Worker 
protection features for specific hazards were addressed in the hazards analysis. No unique radiological or industrial hazards are involved with cask loading activities outside the scope and controls of the radiological and hazardous material protection programs described in Chapters 7 and 8 of the K Basin safety analysis report (SAR) (DESH 1998b). The cask loading operations were reviewed for as low as reasonably achievable (ALARA) considerations to determine the adequacy of the following design features used to protect personnel from exposure to radiological sources.

- The MLS is semi-automated to allow for reduction of worker exposure (including remote operation and viewing stations).

- The CLS design incorporates shielding and ease-of-use components (e.g., sling attachment points, immersion pail support structure [IPSS] locking pins, MCO shield plug, etc.).

The activity job hazard and safety analysis and prejob safety meetings provide the workers with information for identifying and controlling or mitigating hazards. Hazard control and mitigation are accomplished using engineered controls, administrative controls, work restrictions, and personal protective equipment. K Basin administrative procedures requires job hazard analyses as part of job planning. The K Basin SAR (DESH 1998b) identifies the typical worker safety hazards addressed by the job hazards analysis. Comments and clarification to the draft fire hazards analysis have been provided to the cognizant engineer for incorporation into the next revision. No worker safety issues were identified.

Safety inspections are conducted to identify unsafe conditions throughout the facility, including the CLS equipment. Unsafe conditions will result in postings, instituting requirements for personal protective equipment, and/or taking timely corrective actions. All recovery actions from abnormal occurrences may result in additional dose to facility workers.

3.3.2.3.4 Environmental Protection. The CLS equipment design requires that all direct SNF handling operations be conducted under water. CLS operations that occur above the water surface are conducted using an $\mathrm{MCO}$ with a shield plug installed to prevent radioactive material releases to the environment. The CLS uses the immersion pail design to reduce exposure to the facility worker and the potential for radioactive material releases to the environment. The immersion pail maintains a clean surface on the cask in spite of being loaded underwater in the basins. SSCs that protect the safety-class basin boundary from being punctured (i.e., shuttle, immersion pail, and IPSS) also prevent drainage of contaminated water from the entire basin to the surrounding ground areas during normal and abnormal conditions by preventing basinboundary perforation.

3.3.2.3.5 Accident Selection. Accident analysis criteria require that a set of accidents be quantitatively analyzed. The hazards analysis identified a number of postulated hazardous conditions that could have consequences to the Hanford Site worker, the collocated worker, or the offsite individual. These conditions constitute the set of hazards and accidents to be considered for further analysis. The hazards were evaluated to establish the severity of their unprevented or unmitigated consequence. The accidents were binned based on their severity 
HNF-2456, Rev. 0

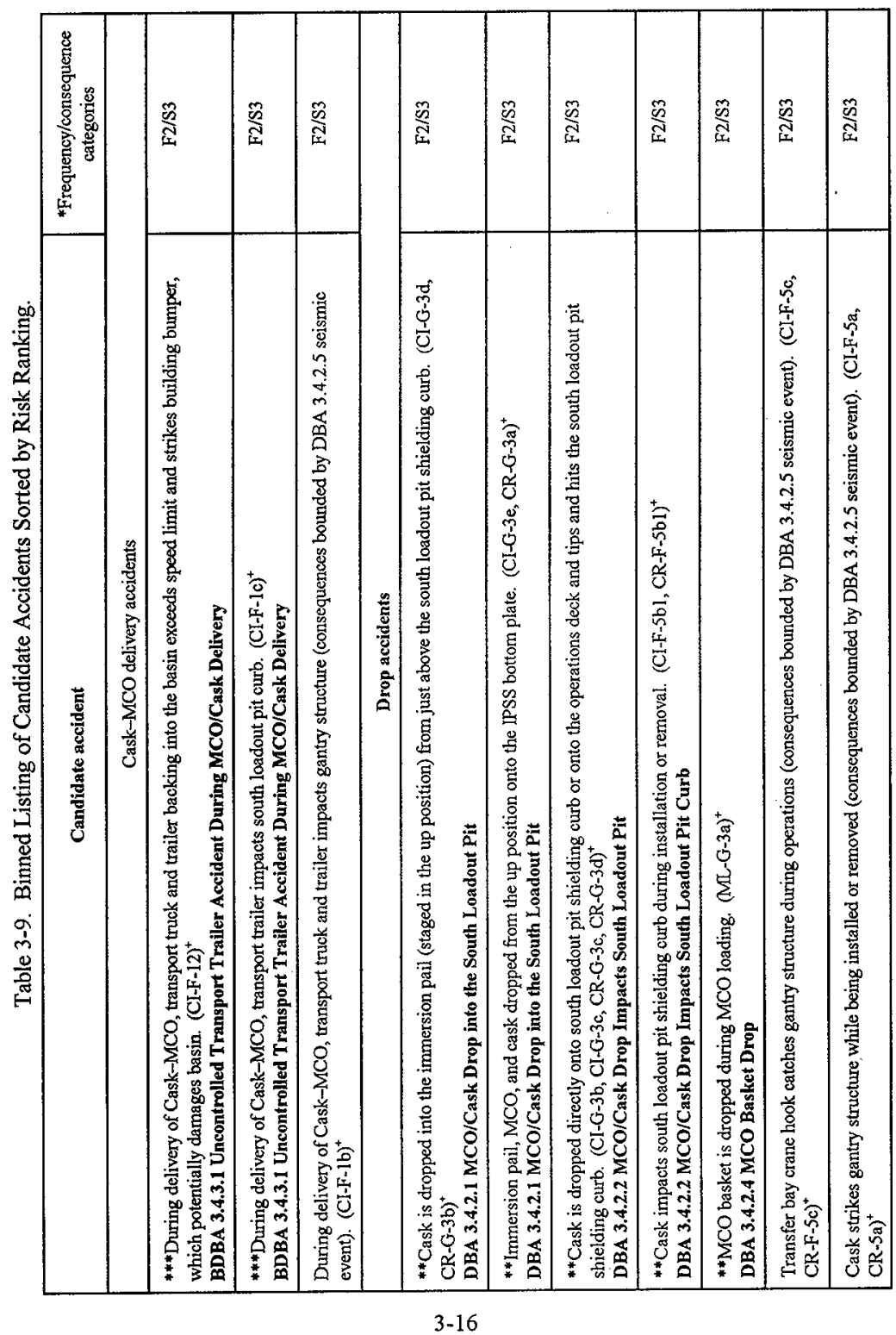


FINF-2456, Rev. 0

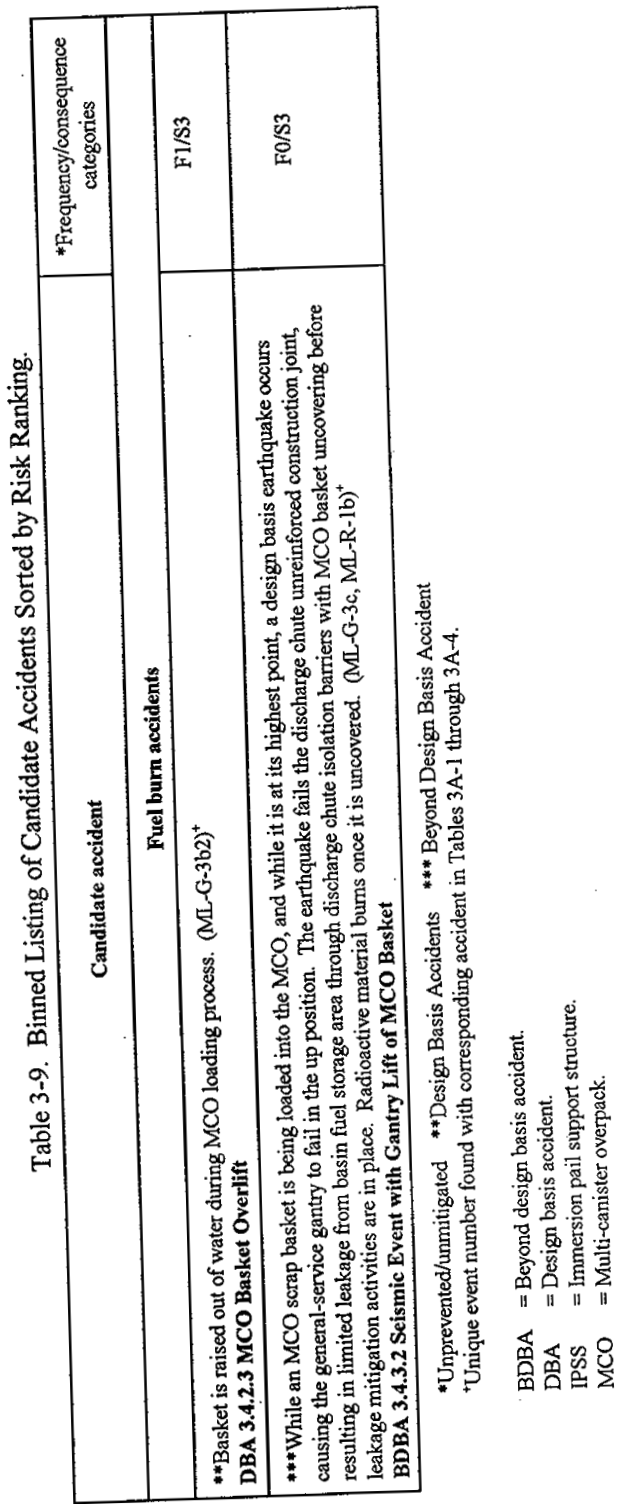


category and the commonality of the accident initiator. Because many of the hazards identified were similar, a set of accident scenario categories (Cask-MCO delivery, drops, and fuel burn) were developed that encompass the identified hazards. Table 3-9 provides the results from the binning process. The design basis seismic event (DESH 1998b) is the only natural-phenomena hazard requiring evaluation as a design basis accident.

Hazard severity category "S0" hazards (events that do not adversely affect facility workers) are covered by the normal facility industrial safety, radiological, or other institutional programs. The hazard severity category "S3" hazards (affecting maximum offsite individual) summarized in Table 3-5, were reviewed to establish a bounding set of representative accidents to identify as DBAs and analyze further. No hazard severity category "S2" hazards (affecting maximum onsite individual) were identified. The hazard severity category " $\mathrm{S} 1$ " hazards (events that can cause an industrial injury, radiological dose, or chemical exposure to one or more facility workers), summarized in Table 3-6, can be further subdivided into the following general hazards:

- Hazards covered by existing control programs:

- Increased worker dose caused by cask loading activities

- Industrial accidents leading to worker injury.

- Hazard covered by new procedures associated with the cask loading activities: increased worker dose caused by cask loading activities.

Safety-class engineered features and criticality prevention specifications (CPS) are applied where necessary to prevent accidental criticality. Preventing an inadvertent criticality eliminates the need for calculating a scenario-specific consequence. Criticality accidents were identified and evaluated in the MCO criticality safety evaluation report (Kessler 1998) and are summarized in Chapter 6.

\subsection{ACCIDENT ANALYSIS}

This section presents the results of the accident analysis. Criticality accidents were analyzed by the MLS CSER (Kessler 1998) and are included in Chapter 6.

The safety analysis process begins with identifying the accident sequence of initiating events and preventive features and mitigative feature responses. Each accident sequence was analyzed to determine if it represented a new DBA or was covered by an already-analyzed DBA. The DBAs were analyzed using deterministic methods and phenomenological calculations to determine the source terms and radiological consequences.

This accident analysis considers releases of radioactive and hazardous material during the following:

- Upset (abnormal but anticipated) conditions

- Accident (unlikely or extremely unlikely) conditions 
- Beyond design basis (beyond extremely unlikely) conditions.

The level of analysis and evaluation required depends on the type of accident and the receptor. Accidents that could result in an unacceptable airborne radioactive dose at the Hanford Site boundary are analyzed in detail, either specifically or by analogy to an accident of the same type that is demonstrably more serious. Onsite and offsite dose consequences were calculated based on the methodology described in HNF-SD-SNF-TI-059, A Discussion on the Methodology for Calculating Radiological and Toxicological Consequences of the Spent Fuel Project at the Hanford Site (FDNW 1998).

The following DBAs were analyzed.

- A fully loaded Cask-MCO is dropped into the south loadout pit.

- A fully loaded Cask-MCO is dropped onto the operations deck, tips over, and hits on the south loadout pit curb, causing a crack that extends below the minimum basin water level.

- An MCO basket is overlifted from the water during MCO loading. Radioactive material is released through aerodynamic entrainment or burning

- An MCO basket is dropped from maximum loading height during MCO loading.

- A design basis seismic event occurs.

The following beyond design basis events were analyzed.

- During delivery of a Cask-MCO, the transport trailer impacts the south loadout pit shielding curb.

- A design basis earthquake occurs, the gantry fails and suspends an MCO basket in the highest position. Water leaks from the basin uncovering the basket, which subsequently burns.

Removal of fuel from the water was analyzed to establish unmitigated dose consequences caused by the release. Preventive and mitigative programs and measures protect the public as well as the facility workers. These include the $\mathrm{K}$ Basins criticality safety program, the radiation protection program, the industrial safety and industrial hygiene programs, procedures and training, and the conduct of operations program. The existing area radiation monitors warn the facility workers in real time of loss of shielding and contribute to defense-in-depth.

\subsubsection{Analysis Method}

The accident analysis uses a specific and consistent method to quantify the consequences of the postulated accidents and natural-phenomena events selected for analysis. All accidents 
requiring radioactive material release calculations that were identified to be evaluated for the cask loading operations were bounded by similar DBAs in the fuel retrieval system SAD (Peck 1998). The models, data, and other bases used to calculate accident source terms, release fractions, atmospheric dispersion, and dose consequences for the selected accidents are contained in Appendix 3B of the fuel retrieval system SAD.

The following steps were used to analyze each accident.

- Scenario Development. A detailed sequence of steps needed to initiate and develop each accident was prepared using conservative assumptions and a clearly defined logic path. Preventive and mitigative design features also were considered.

- Source Term Analysis. Realistic maximum source terms were developed for each accident that could cause a radionuclide release. The source terms were based on known compositions and quantities of hazardous materials handled in the $\mathrm{K}$ Basins. The analysis includes the MAR, the release fraction or rate that determines the initial source term, and the overall or process leak path factors that determine the release from the facility.

- Consequence Analysis. The consequence analysis was structured to determine the unmitigated receptor doses for each location. Consequence calculations were performed that analyzed the doses to onsite personnel and the general public for accidents that could produce such exposures. This section also includes an estimate of the probability of occurrence and frequency category for the postulated accident.

- Comparison to Guidelines and Limits. The estimated unmitigated radiological consequences (risk) for the accident were compared to the risk evaluation guidelines (Table 3-1) to determine the need for safety equipment to prevent or mitigate the accident's consequences. The comparison also was used to determine the equipment's effectiveness.

- Summary of Safety-Class SSCs and TSR Controls. The requirements for safety-class or safety-significant SSCs and TSRs depend on the results and conclusions from the detailed accident analysis. The analysis for each accident identifies the safety SSCs and the assumptions judged to require TSR coverage to meet evaluation guidelines.

\subsubsection{Design Basis Accidents}

The types of accidents considered included internally initiated operational accidents and natural-phenomena events for the Site that could affect the CLS equipment or operations. External human-caused events that can cause releases at the facility or have major impact on the facility operations are covered by the K Basin SAR (DESH 1998b) and are not affected by CLS. Each accident evaluated contains the components listed under Section 3.4.1. 
3.4.2.1 Cask-MCO Drop into the South Loadout Pit. This accident frequency is characterized as an unlikely accident. Analysis has shown that a fully loaded cask dropped into the south loadout pit will perforate the safety-class basin boundary (Kee 1997a and 1997b). Use of safety-class SSCs (i.e., IPSS and immersion pail) prevent the basin boundary from being perforated during this accident.

3.4.2.1.1 Scenario Development. This accident involves the drop of a loaded Cask-MCO into the south loadout pit during cask removal. The Cask-MCO can drop either into the immersion pail (pinned in the top IPSS position) or onto the IPSS. The Cask-MCO drop into the south loadout pit can be initiated by the following:

- Transfer bay crane failure caused by a seismic event, a general power failure, or a mechanical or structural failure

- $\quad$ Sling failure

- Operator error.

This accident assumes that the fully loaded Cask-MCO with the lid, weighing $60,000 \mathrm{lb}$, is being lifted out of the south loadout pit for transfer back to the transport. The Cask-MCO drops from a height just above the south loadout pit curb into the immersion pail, which is pinned in the top position of the IPSS (Chenault 1998d). The IPSS locking pins are sheared and the immersion pail is dropped to the bottom of the south loadout pit impacting the bottom plate of the IPSS. Resultant forces are transmitted through the IPSS feet to the safety-class basin boundary (the south loadout pit floor).

The fully loaded Cask-MCO could be dropped from the same height directly onto the IPSS and transmit energy through the IPSS to the safety-class basin boundary (Chenault 1997).

3.4.2.1.2 Source Term Development. The MCO shield plug and cask lid are assumed to maintain their integrity during the drop (Edwards 1998 and Lorenz 1997). This accident does not result in any radiological release; therefore, no source terms are developed.

3.4.2.1.3 Consequence Analysis. The drop analysis is documented by HNF-1897, Cask and Pail Drops onto the K Basin Immersion Bottom Plate (Chenault 1998d). The analysis concludes that the bounding drop of the fully loaded Cask-MCO from a height just above the south loadout pit curb into the immersion pail, which is pinned in the top position does not perforate the basin boundary. Although the analysis was not focused on impact to the adjacent drain valve, the resultant maximum strain contours of the energy transmitted through the concrete to the drain valve extend only 2 in. from the IPSS foot. Thus, it is concluded that the drain valve is unaffected by this drop accident.

A drop of a fully loaded Cask-MCO situated in the immersion pail pinned in the top position being dropped onto the bottom plate of the IPSS also was analyzed and found to be acceptable (Chenault 1998d). 
The IPSS and immersion pail are designed and analyzed to withstand the forces of a seismic event and the related drop events without failure (Brisbin $1997 \mathrm{~b}$ and Webb 1998b).

\subsection{Comparison of Guidelines. Not applicable.}

3.4.2.1.5 Summary of Safety-Class SSCs and TSR Controls. The IPSS and the immersion pail are required to be safety class to limit the energy transmitted to the safety-class basin boundary and prevent a basin boundary perforation, as required by the $\mathrm{K}$ Basins $\mathrm{SAR}$ (DESH 1998b).

All four immersion pail support structure locking pins must be in place to hold the immersion pail in the top IPSS position during cask removal. The analysis for a fully loaded cask drop into the immersion pail when it is pinned in the top position of the IPSS credits some energy absorption to the drop forces transferred through the immersion pail to the IPSS through the locking pins (Chenault 1998d). A TSR is proposed to ensure that the bounding analysis is maintained.

3.4.2.2 Cask-MCO Drop Impacts South Loadout Pit Curb. The following accident scenarios caused by either operations or natural phenomena postulate cask interaction with the south loadout pit curb during operations:

- Linear strike by cask onto the south loadout pit curb during installation or removal

- Vertical drop of cask onto the south loadout pit curb during installation or removal

- Cask drops on operations deck and subsequently tips over striking on the south loadout pit curb during installation or removal.

A postulated cask dropping on the operations deck and subsequently tipping over, striking on the south loadout pit curb, during cask removal results in through-wall cracking part way down the south loadout pit wall and drainage of some basin water. A cask impacting the south loadout pit curb has an unmitigated frequency of unlikely.

3.4.2.2.1 Scenario Development. A fully loaded Cask-MCO weighing $60,000 \mathrm{lb}$ is dropped during removal from the south loadout pit while being moved to the cask transport. It is dropped onto the operations deck, tips over, and impacts the 2 -ft-high south loadout pit curb with concentrated angular force. The accident can be initiated by any of the following:

- Transfer bay crane failure caused by a seismic event, a general power failure, or mechanical or structural failure

- $\quad$ Sling failure

- Operator error.

The drop height is bounded by the maximum crane lift during transfer $(50.75 \mathrm{in}$. above the 
operations deck) (Praga and Pajunen 1998). The top crane trolley speed is $20.5 \mathrm{ft} / \mathrm{min}$ laterally (east-west) (DESH 1998b).

3.4.2.2.2 Source Term Development. The MCO shield plug and cask lid maintain their integrity during the drop (Edwards 1998 and Lorenz 1997). This accident does not result in any radiological release; therefore, no source terms were developed.

3.4.2.2.3 Consequence Analysis. The accident is analyzed in SNF-2555 (Chenault 1998c). The damage to the south loadout pit wall was found to be as shown in Figure 3-4. The longest crack down the south loadout pit wall that would produce a leak path is $37 \mathrm{in}$. below the maximum water level in the $\mathrm{K}$ East Basin $(-3 \mathrm{ft} 5 \mathrm{in}$. elevation) and $27 \mathrm{in}$. below the maximum water level in the $\mathrm{K}$ West Basin (-4 ft 3 in. elevation), as shown in Figure 3-4. Therefore, damage will occur below the water line. The $\mathrm{K}$ West Basin water level is used for analysis because the $\mathrm{K}$ West Basin water level is closer to the fuel at the bottom of the basin. The through-wall crack was determined to be 8 in. wide.

The K Basins SAR (DESH 1998b) DBA, Section 3.4.2.3, "Loss of Pool Coolant - Design Basis Earthquake", provides the authorization basis for basin pool water levels. This accident states that "the leak rate limit for a design basis earthquake is 3,000 gph.and results in a $1.08 \mathrm{ft} /$ day level decrease." It also states that "personnel entry for leak mitigation such as 'bentonite' application would be possible for up to approximately the 5.5-ft level (approximately $1 \mathrm{R} / \mathrm{hr}$ from stored fuel per Table 7-2)."

If the accident is initiated by the Cask-MCO drop, the water will drain down to the $-6.5-\mathrm{ft}$ level. This can be considered to occur rapidly because of the extreme damage to the concrete (Chenault 1998c). However, no further water will be drained, which keeps the water level above the required 5.5-ft level above the fuel (DESH 1998b).

If the accident is caused by a design basis seismic event, the basin water will drain rapidly down to the -6.5 -ft, then drain at $3,000 \mathrm{gph}$ or $1.08 \mathrm{ft}$ per day (DESH 1998b). The initial basin water drainage as a result of the south loadout pit through-wall crack down to the -6.5-ft level would reduce the response time by 1.6 to 11.8 days, as shown by the following calculations:

Minimum water level at $\mathrm{K}$ West $=-4 \mathrm{ft}-9 \mathrm{in}$.

Through-wall crack extends down to -6 ft 6 in.

Amount of water drainage $=(-4 \mathrm{ft} 9 \mathrm{in})-.(-6 \mathrm{ft} 6 \mathrm{in})=.1.75 \mathrm{ft}$ Therefore $1.75 \mathrm{ft} \div 1.08 \mathrm{ft} / \mathrm{day}=1.6$ days

Response time reduced to 13.4 days -1.6 days $=11.8$ days

The SAR requires that makeup water be provided within 7 days after the initiation of the leak. Therefore, this accident scenario will not adversely affect the authorization basis established by the K Basins SAR "Loss of Pool Coolant" DBA (DESH 1998b) because the response time is still more than 7 days. 
3.4.2.2.4 Comparison of Guidelines. This accident is adequately bounded by the K Basins SAR "Loss of Pool Coolant" DBA (DESH 1998b). Comparing radiation doses and exposures to the exposure guidelines is unnecessary when little or no dose is present. Continued maintenance of the basin water level ensures that receptor dose or exposure for this accident sequence is far below the exposure guidelines.

3.4.2.2.5 Summary of Safety-Class SSCs and TSR Controls. No additional safetyclass SSCs or TSR controls are required as a result of this accident scenario.

3.4.2.3 MCO Basket Overlift Accident. This unmitigated accident is characterized as an unlikely operational accident involving the release of radioactive materials caused by a postulated uranium fire.

Most of the $\mathrm{K}$ Basin fuel is intact and clad with zirconium so that the uranium metal has limited contact with water, oxygen, and hydrogen. However, scrap does have surfaces that are exposed. If exposed to water, oxygen, and hydrogen, uranium metal fuel such as that stored in the $\mathrm{K}$ Basins will react to form uranium oxide and/or uranium hydride (WHC 1995). These reactions are exothermic and, under certain conditions, can release sufficient energy to cause a thermal excursion. Materials that respond in this manner are termed "pyrophoric" and the technical term for the excursion is "ignition." While the concept of ignition is most often associated with burning with associated flame, the term "ignition" is used in this context as the point at which the system has insufficient heat removal capability to balance the heat generated by this reaction (WHC 1995). At this point, a rapid temperature rise occurs that is terminated by the consumption of either the material or the available reactant. Fuel pyrophoricity is a key concern from an accident standpoint because such an event may provide the motive force for a release of radioactivity (WHC 1995). Convective cooling would probably prevent ignition from occurring after the MCO scrap basket was inadvertently removed from the basin water, but no specific analysis is available to conclude that ignition is not possible. Specific analysis demonstrating that a canister containing scrap would not ignite under similar or worse conditions has been conducted (Porten and Crowe 1994). Because the MCO basket contains significantly more scrap, the analysis cannot easily be extended to cover the MCO basket.

3.4.2.3.1 Scenario Development. This accident examines the consequences of an MCO basket being overlifted from the basin water into air during the MCO loading process.

Two potential consequence scenarios exist for overlifting an MCO basket. In the first, the fuel burns; in the second, the fuel does not burn, but corrosion products are released into the air. Scrap baskets, which have significantly higher pyrophoric material surfaces exposed, are assumed to burn. Intact fuel elements loaded in MCO baskets are assumed to not burn because they have limited exposed pyrophoric material surfaces.

The following assumptions were used for analysis:

- The accident occurs over 1 to 2 hours. 
- The projected surface area of the fuel in the MCO basket is the area available for release.

- The scrap fuel is assumed to have a depth of contamination of $1 \mathrm{~mm}$ from which radiological material can be released.

- $\quad$ Airborne release fractions (ARF) and respirable fractions (RF) based on bounding values for burning uranium from DOE (1994) are conservative.

- The MCO scrap basket is assumed to contain $980 \mathrm{~kg}$ (approximately 42 assemblies) of scrap fuel, the maximum allowed by the fuel retrieval system criticality safety evaluation report (Kessler and Peck 1998). The source term and consequences are the same as those in the "MCO Scrap Basket Over-Lift" design basis accident (Peck 1998).

- The MCO fuel basket overlift resulting in an aerodynamic entrainment of corrosion products is similar to the non-burn fiel retrieval system "Primary Clean Wash Basket Overlift" design basis accident (Peck 1998) modified to account for differences in MAR and surface area.

- This event is considered to be unlikely based on the projected number of MCO basket moves.

A design basis seismic event could initiate an event that results in the same consequences. Aerodynamic entrainment after a seismic event is an extremely unlikely event; however, its consequences are bounded by this accident. A fuel burn is considered beyond extremely unlikely. That event is fully described by the beyond design basis accident 3.4.3.2, "Seismic Event with Gantry Lift of MCO Basket." Although the frequencies of the seismic event are much lower, the resulting consequences are the same.

3.4.2.3.2 Source Term Development. The source term for the burn scenario, the same as calculated for the "MCO Scrap Basket Over-Lift" design basis accident, is $9.8 \times 10^{2} \mathrm{~g}$ (Peck 1998).

The source term for the non-burn scenario is taken from the fuel retrieval system "Primary Clean Wash Basket Overlif" design basis accident with modifications (Peck 1998). The MAR depends on the surface area exposed to air. The MCO basket MAR term is determined by the ratio of the its surface area to the area of the fuel retrieval system primary clean machine wash basket. The wash basket area is $6966 \mathrm{~cm}^{2}$. The area of the MCO basket is $2565 \mathrm{~cm}^{2}$, assuming a $22.5 \mathrm{~cm}$ radius for the basket. The MAR for the wash basket is $1.31 \times 10^{4} \mathrm{~g}$. The MAR for the MCO basket is then $(2565 / 6966) \times\left(1.31 \times 10^{4} \mathrm{~g}\right)$ or $4.8 \times 10^{3} \mathrm{~g}$. 
HNF-2456, Rev. 0

The airborne source term for the MCO basket is estimated by the following equation:

where

$$
\mathrm{M}=(\mathrm{MAR})(\mathrm{ARF})(\mathrm{RF})(\mathrm{LPF})
$$

$$
\begin{aligned}
& M \quad=\text { respirable source term } \\
& \mathrm{MAR}=\text { material at risk }(\mathrm{Ci} \text { or grams })=4.8 \times 10^{3} \mathrm{~g} \\
& \mathrm{ARF}=\text { airborne release fraction }=1 \times 10^{-3}(\mathrm{DOE} 1994) \\
& \mathrm{RF} \quad=\text { respirable fraction }=1.0(\mathrm{DOE} 1994) \\
& \mathrm{LPF}=\text { leak path factor }=1.0
\end{aligned}
$$

Therefore $\mathrm{M}=4.8 \mathrm{~g}$.

3.4.2.3.3 Consequence Analysis. The consequence analysis for the burn scenario is the same as for the fuel retrieval system design basis accident, "MCO Scrap Basket Over-Lift." Dose consequences are summarized in Table 3-10.

The consequence analysis for the aerodynamic entrainment scenario is as follows. The calculation of inhalation dose from airborne radioactive material transported downwind is computed as the product of the quantity released, the air transport factor, the inhalation rate, and the unit dose factor for the radionuclide mixture released. This is summarized in the following equation.

where

$$
\mathrm{DE}=(\mathrm{M})\left(\chi / \mathrm{Q}^{\prime}\right)(\mathrm{BR})(\mathrm{UD})
$$

$\mathrm{DE} \quad=50$-year committed effective dose equivalent, rem (Sv)

$\mathrm{M} \quad=$ mass released into the air as respirable particles $=4.8 \mathrm{~g}$

$\chi / Q^{\prime}=$ air transport factor $=1.24 \times 10^{-2} \mathrm{~s} / \mathrm{m}^{3}$ for onsite worker $1-$ to $2-\mathrm{hr}$ duration

$\mathrm{BR}=$ average inhalation rate during the release $=3.33 \times 10^{-4} \mathrm{~m}^{3} / \mathrm{s}($ FDNW 1998)

UD $\approx$ committed effective dose equivalent per gram inhaled $=4.38 \times 10^{5} \mathrm{rem} / \mathrm{g}$ from Table 3B-1A (Peck 1998).

Therefore, the dose for the onsite worker is calculated to be

$$
\begin{aligned}
\mathrm{DE} & =(4.8 \mathrm{~g})\left(1.24 \times 10^{-2} \mathrm{~s} / \mathrm{m}^{3}\right)\left(3.33 \times 10^{-4} \mathrm{~m}^{3} / \mathrm{s}\right)\left(4.38 \times 10^{5} \mathrm{rem} / \mathrm{g}\right) \\
& =8.7 \mathrm{rem} \operatorname{EDE}\left(8.7 \times 10^{-2} \mathrm{~Sv}\right)
\end{aligned}
$$

Doses for the other receptors are provided in Table 3-11.

3.4.2.3.4 Comparison of Guidelines. The consequence results of the analysis are presented in Tables 3-10 and 3-11. The burn scenario produces an unmitigated onsite 
consequence of $1.8 \times 10^{3} \mathrm{rem} \mathrm{EDE}$, which is above both the onsite risk acceptance guidelines (10 rem for unlikely events) and the 0.5 rem EDE safety-class criterion. Therefore, safety-class SSCs are required to prevent the accident. Comparing the consequences in Tables 3-10 and 3-11 shows that the consequences from a burn bound the consequences from aerodynamic entrainment.

3.4.2.3.5 Summary of Safety-Class SSCs and TSR Controls. The unmitigated consequences shown in Table 3-10 exceed the risk evaluation guidelines and limits for the onsite receptor for the MCO scrap basket burn. The consequences to the public at the Hanford Site boundary are below the risk evaluation limits. Therefore, the MCO basket overlift accident requires prevention or mitigation only for the protection of the onsite worker.

While the risk evaluation guidelines for the onsite receptor are the only guidelines exceeded, the prevention feature must be designated as safety-class because the offsite dose consequences exceeds $0.5 \mathrm{rem}$, based on the safety-class requirements of Appendix 4A. The gantry design physically prevents overlift of a basket, even if the MLS control system fails. The following design features allow the gantry to meet the safety-class requirements.

- The gantry support structure height is fixed.

- Hard-stop mechanical interferences separate the grapple and the gantry grapple, mast, and weldment. They prohibit lift above designed lift capability.

- The lift mechanism is a ballscrew. Although, the primary lift restriction is the hardstop mechanical interference, the lift height also is limited by the length of the ballscrew thread.

The design features will be verified by quality control during construction acceptance testing. No safety-significant SSCs were identified. No TSR controls are required as a result of this accident.

Table 3-10. Surnmary of Unmitigated Dose Consequences-Ignition of Scrap Equivalent to 42 Fuel Assemblies (Peck 1998).

\begin{tabular}{|c|c|c|c|}
\hline \multirow{2}{*}{ Receptor location } & \multicolumn{2}{|c|}{ Unmitigated } & \multirow{2}{*}{$\begin{array}{c}\text { Guidelines } \\
\text { rem }\end{array}$} \\
\hline & $\chi / Q^{\prime a}$ & rem $\operatorname{EDE}(\mathrm{Sv})$ & \\
\hline $100 \mathrm{~m}$ east (onsite) & $1.24 \times 10^{-2}$ & $\begin{array}{c}1.8 \times 10^{3} \\
(18)\end{array}$ & $10^{\mathrm{b}}$ \\
\hline $\begin{array}{l}\text { Hanford Site boundary }(12,040 \mathrm{~m} \text { west) } \\
\text { (offsite) }\end{array}$ & $2.6 \times 10^{-5}$ & $\begin{array}{c}3.8 \\
\left(3.8 \times 10^{-2}\right) \\
\end{array}$ & $5^{b}$ \\
\hline Near river bank ( $480 \mathrm{~m}$ northwest) & $5.5 \times 10^{-4}$ & $\begin{array}{c}80 \\
(0.8)\end{array}$ & N/A \\
\hline
\end{tabular}

Notes: "From Table 3B-8 (Peck 1998).

${ }^{b}$ At anmual frequency of $>1 \times 10^{-4}$ to $\leq 1 \times 10^{-2}$.

$\mathrm{EDE}=$ effective dose equivalent. 
Table 3-11. Summary of Unmitigated Dose Consequences-Oxidation of MCO Fuel Basket.

\begin{tabular}{|l|c|c|c|}
\hline \multirow{2}{*}{ Receptor location } & \multicolumn{2}{|c|}{ Unmitigated } & \multirow{2}{*}{$\begin{array}{c}\text { Guidelines } \\
\text { rem }\end{array}$} \\
\cline { 2 - 4 } & $\chi^{\prime} / \mathrm{Q}^{\mathrm{a}}$ & $\operatorname{rem} \mathrm{EDE}(\mathrm{Sv})$ & $10^{\mathrm{b}}$ \\
\hline $100 \mathrm{~m}$ east (onsite) & $1.24 \times 10^{-2}$ & $\begin{array}{c}8.7 \\
\left(8.7 \times 10^{-2}\right)\end{array}$ & \\
\hline $\begin{array}{l}\text { Hanford Site boundary (12,040 m west) } \\
\text { (offsite) }\end{array}$ & $2.6 \times 10^{-5}$ & $\begin{array}{c}1.8 \times 10^{-2} \\
\left(1.8 \times 10^{-4}\right)\end{array}$ & $5^{\mathrm{b}}$ \\
\hline Near river bank (480 m northwest) & $5.5 \times 10^{-4}$ & $\begin{array}{c}3.9 \times 10^{-1} \\
\left(3.9 \times 10^{-3}\right)\end{array}$ & N/A \\
\hline
\end{tabular}

Notes: ${ }^{9}$ From Table 3B-8 (Peck 1998).

${ }^{b}$ At annual frequency of $>1 \times 10^{-4}$ to $\leq 1 \times 10^{-2}$.

$\mathrm{EDE}=$ effective dose equivalent.

3.4.2.4 MCO Basket Drop. Analysis has shown that an MCO basket dropped from the peak loading height into the south loadout pit will perforate the basin boundary (Chenault 1998e). Because perforation of the safety-class basin boundary is not acceptable, prevention is required (DESH 1998b). With prevention, this accident is characterized as a beyond extremely unlikely operational accident involving the release of radioactive materials caused by the penetration of the basin and resultant aerodynamic release of fuel. This accident is considered beyond extremely unlikely because of the safety-class SSC basin protective features (i.e., the energy absorption capabilities of the shuttle). In addition, the grapple uses an anti-release mechanism for defense in depth.

3.4.2.4.1 Scenario Development. This accident involves the drop of an MCO basket from the maximum lift height during the MCO loading operations. The MCO basket drop can be initiated by gantry grapple failure caused by a seismic event or mechanical or structural failure.

The accident assumes that a fully loaded MCO basket $(3,200 \mathrm{lb})$ is being lifted by the MLS gantry's grapple for loading into the MCO. The MCO basket drops from the maximum loading height $(-8 \mathrm{ft} 0 \mathrm{in}$. elevation).

3.4.2.4.2 Source Term Analysis. No release is anticipated from this accident, so no source terms were developed.

3.4.2.4.3 Consequence Analysis. Because an unmitigated $\mathrm{MCO}$ basket drop would penetrate the basin boundary, prevention is required. The shuttle will prevent the consequences of this accident by absorbing the drop energy and preventing basin boundary perforation. Spilling the fuel into the south loadout pit has been analyzed as acceptable in HNF-2151, Criticality Safety Evaluation Report for the Multi-Canister Overpack Loading and Handling at the $K$ Basins (Kessler 1998), and HNF-SD-SNF-CSER-010, Criticality Safety Evaluation Report for the K Basin Fuel Retrieval Subproject (Kessler and Peck 1998). 


\subsection{Comparison to Guidelines. Not applicable.}

3.4.2.4.5 Summary of Safety-Class SSCs and TSR Controls. The MLS shuttle limits energy transmitted to the safety-class basin boundary and prevents perforation of the safety-class basin boundary. The safety-class SSC is the MLS shuttle (to prevent basin boundary perforation). No safety-significant SSCs were identified. No TSR controls are required as a result of this accident scenario; however, a criticality limit maintaining sludge depth of less than 1.5 in. is required to protect criticality assumptions (Kessler and Peck 1998).

3.4.2.5 Seismic Event. During operation, the CLS equipment may be subjected to the forces of a design basis seismic event (DESH 1998b). This accident is categorized as a unlikely natural phenomena event.

3.4.2.5.1 Scenario Development. A seismic event is postulated to occur during cask loadout operations with maximum loads in place. The following is assumed to occur:

- MLS shuttle functions as designed to remain in place

- MCO basket drops or spills fuel onto transfer channel floor or queue

- MLS gantry and support structure do not fall into the south loadout pit

- MCO basket is released from the gantry grapple during MCO loading and drops onto the shuttle

- MLS shuttle holds together and absorbs basket drop energy, preventing basin boundary perforation

- Loaded cask drops into the south loadout pit

- IPSS functions as designed to remain in place and absorb energy of bounding drops

- Immersion pail functions as designed to remain in place and absorb energy of bounding drops

- Loaded cask drops and impacts south loadout pit curb.

3.4.2.5.2 Source Term Analysis. No release is anticipated from this accident, so no source terms were developed.

3.4.2.5.3 Consequence Analysis. The Cask-MCO and cask transport are qualified for drops and tip-overs (Edwards 1998, Kee 1996).

The MLS shuttle has been designed, analyzed, and procured to withstand a design basis seismic event without structural failure (Brisbin 1997c). If an MCO basket falls from the shuttle 
onto the transfer channel floor, the impact to the basin is bounded by the consequences described in the K Basins SAR, Table 3-10 (DESH 1998b). An MCO basket spill in the transfer channel or on the FRS MCO basket queue will not cause a criticality event (Kessler 1998, Kessler and Peck 1998).

If the gantry fails during a seismic event, the bounding drop mass will include the loaded MCO basket because the gantry and gantry support structure are designed to not fall into the south loadout pit during or after a seismic event (Moody 1998). The drop load impacts the shuttle, which will be designed to completely absorb the energy without damage to the safetyclass basin boundary. Resultant MLS shuttle rebound forces on the FRS MCO basket queue or the transfer channel floor and wall are bounded by the drop of the MLS shuttle during installation (Chenault 1998c).

If a loaded Cask-MCO is dropped into the south loadout pit during removal, it impacts the immersion pail, which is pinned into the IPSS top position. The IPSS locking pins and immersion pail absorb some energy, while the IPSS frame and bottom plate absorbs most of the energy. Resultant forces transmitted through the IPSS feet into the south loadout pit floor concrete cause damage; however, the safety-class basin boundary is not perforated (Chenault 1997, 1998d). A loaded Cask-MCO dropped directly onto the IPSS during removal has been found to not result in penetration of the basin boundary (Chenault 1997).

Seismic forces on the IPSS and immersion pail are bounded by the Cask-MCO drop forces. The IPSS and immersion pail do not catastrophically fail during a bounding Cask-MCO drop, therefore, it is concluded that the IPSS and immersion pail will remain intact during a seismic event (Chenault 1997, 1998d). Seismic induced forces from a loaded Cask-MCO in the IPSS on the south loadout pit walls are shown to be acceptable (Webb 1998b).

Dropping a loaded Cask-MCO onto the operations deck and its subsequent tip over onto the south loadout pit curb has been analyzed and has been shown to not have onsite or offsite dose consequences (see Section 3.4.2.2).

Therefore, all the consequences of a seismic event have been analyzed and are shown to be acceptable.

3.4.2.5.4 Comparison to Guidelines. The following guidelines apply to this accident: the basin safety-class boundary is not perforated and these single failures do not cause a criticality. Because a postulated seismic event and related drops do not perforate the basin boundary and spills will not result in a criticality; the guidelines are met.

3.4.2.5.5 Summary of Safety-Class SSC and TSR Controls. The analyses associated with the postulated seismic event requires that the following equipment be safety-class:

- $\quad$ MLS shuttle (to prevent basin perforation)

- $\quad$ IPSS (to prevent basin perforation)

- Immersion pail (to prevent basin perforation)

- $\quad$ MLS gantry (to prevent basin perforation). 
The design features will be verified by quality control inspection on receipt or before operation and maintain the change control program required by the existing $\mathrm{K}$ Basin TSR.

\subsubsection{Beyond Design Basis Accidents}

DOE Order 5480.23, Nuclear Safety Analysis Reports, requires that accidents beyond the DBAs be evaluated to provide a perspective on the residual risk associated with the operation of the CLS equipment and potential design enhancements. Beyond design basis accidents are typically considered as beyond extremely unlikely accidents with a frequency of occurrence realistically calculated to be $<10^{-6}$ per year (DOE Order 6430.1A, Section 0200-1.2, "Radiological Siting Requirements"). The following beyond DBAs are postulated and analyzed.

\subsubsection{Uncontrolled Transport Trailer Accident During Cask-MCO Delivery. With} credited prevention, this accident is characterized as a beyond extremely unlikely operational accident involving the release of radioactive material because of an airborne release as a result of the potential draining of the basin. The draining of the basin is initiated by the trailer, which, while delivering the Cask-MCO, backs into the south loadout pit curb. The impact produces through-wall cracking down the south loadout pit wall. This accident is considered beyond extremely unlikely because of the current prevention mechanisms in place under normal conditions. These mechanisms include the following:

- Independent tractor and trailer brakes (engineered features)

- Physical barriers (engineered features)

- In-basin speed limits (administrative)

- Controlled entry procedure (administrative)

- Qualified drivers (administrative)

- Supervisor in the truck (administrative)

- Spotter (administrative)

- Regular tachometer calibration (administrative)

- Regularly scheduled truck maintenance (administrative).

3.4.3.1.1 Scenario Development. The scenarios postulated include the following:

1. During delivery of Cask-MCO, an uncontrolled transport trailer impacts the south loadout pit curb.

2. During delivery of Cask-MCO, an uncontrolled transport tractor-trailer exceeds the basin speed limit and strikes building bumper posts and potentially backs into the basin. The additional mass backing into the basin has the potential to penetrate the safety-class basin boundary.

The uncontrolled tractor-trailer accident scenarios leading to the basin cracking and water leaking are described in detail in the $\mathrm{K}$ Basins SAR beyond design basis accident, "Uncontrolled Railroad/Train/Vehicle," Section 3.4.3.1 (DESH 1998b). These two scenarios are bounded by the referenced beyond DBA as described in the following paragraphs. 
An impact energy analysis was performed for scenario 1 and compared to the forklift truck impacting the south loadout pit curb covered in the K Basins SAR (DESH 1998b and Webb 1998b). The analysis identified the gross weight of the tractor-trailer to be $104,870 \mathrm{lb}$ (Kee 1997). The maximum direct impact kinetic energy allowed to engage the K Basins south loadout pit curb, shown by Equations 3-1 and 3-2, is 31,753 ft-lb (DESH 1998b). The maximum allowable velocity is calculated by incorporating the gross weight of the tractor-trailer into a kinetic energy equation and setting it equal to the maximum allowable kinetic energy, as shown in Equation 3-3. The resultant maximum velocity was calculated to be $3 \mathrm{mph}$ (Equation 3-5). Therefore, an uncontrolled tractor-trailer impacting the south loadout pit curb with a speed of $3 \mathrm{mph}$ is acceptable. Conservatism is added by including the maximum tractor fuel weight in the gross weight. The tractor is highly unlikely to be carrying a full fuel load during the delivery.

Scenario 2 is covered by the K Basins SAR, which states that the sequence probability of this event occurring is $<2.7 \times 10^{-11}$ (DESH 1998b).

Lastly, the tractor-trailer combination designed to be used for transport of the Cask-MCO is configured to be capable of engaging the protective devices (stops and bumpers).

$$
\begin{array}{ll}
\text { Eq. 3-1 } & \text { Kinetic Energy (K.E.) }=\frac{\text { Weight } * \text { velocity }{ }^{2}}{2 * \text { gravity }} \\
\text { Eq. 3-2 } & \text { K.E. }=\frac{104,870 * \mathrm{v}^{2}}{2 * 32.2}=1628 * \mathrm{v}^{2} \\
\text { Eq. 3-3 } & 1628 * \mathrm{v}^{2}=31,753 \\
\text { Eq. 3-4 } & \mathrm{v}^{2}=19.5 \frac{\mathrm{ft}^{2}}{\mathrm{sec}^{2}} \\
\text { Eq. 3-5 } & \mathrm{v}=4.4 \frac{\mathrm{ft}}{\mathrm{sec}} * \frac{1 \mathrm{mile}}{5280 \mathrm{ft}} * \frac{3600 \mathrm{sec}}{1 \text { hour }}=3.0 \mathrm{mph}
\end{array}
$$

3.4.3.1.2 Source Term Analysis. No radiological release is anticipated from this accident.

3.4.3.1.3 Consequence Analysis. The uncontrolled tractor-trailer accidents scenarios leading to the basin cracking and water leakage have been analyzed by the K Basins SAR beyond design basis accident, Section 3.4.3.1, "Uncontrolled Railroad/Train/Vehicle" (DESH 1998b); the sequence probability of this event occurring is $<2.7 \times 10^{-11}$.

\subsection{Comparison to Guidelines. Not applicable.}

3.4.3.1.5 Summary of Safety-Class SSCs and TSR Controls. The TSR contains limiting conditions for operation (LCO) regarding the positioning of the railroad switches and derailers. Actions are specified if the components are not in the required position, and 
surveillances are specified to verify compliance with the LCOs. Current administrative controls are acceptable to control the movement of the Cask-MCO tractor-trailer transport into the basin transfer area.

No additional safety-class SSCs are required for these accidents. Current SAR safetyclass SSCs continue to be required (i.e., bumpers). The trailer must be configured to impact the bumpers.

3.4.3.2 Seismic Event with Gantry Lift of MCO Scrap Basket. This accident is characterized as a beyond design basis accident. It is initiated by a seismic event while an MCO scrap basket is being loaded into the MCO. The reduced water level resulting from seismically induced basin leakage can cause an MCO scrap basket to be exposed to air. The gantry is assumed to fail with the basket in the highest MCO loading position. The pyrophoric scrap is assumed to burn once exposed to air.

3.4.3.2.1 Scenario Development. It is assumed that a full basket of scrap is being loaded from the shuttle to the MCO when a design basis earthquake occurs. As a result of the basket being lifted, less water is covering the basket. The gantry is assumed to fail with the basket in the highest loading position. Earthquake damage then causes the basin to begin draining at a rate of $3,000 \mathrm{gal} / \mathrm{hr}$ (DESH 1998b). The water drains enough to partially or fully expose the MCO basket with attendant potential for release of radioactive material to the atmosphere from combustion.

The peak basket height of $-8 \mathrm{ft} 0$ in. elevation combined with the minimum operational basin water level (bounded by the water level in the $K$ West Basin) of $-4 \mathrm{ft} 9$ in. elevation provides a minimum amount of water cover equaling 39 in., as shown in Figure 3-5 (Brisbin 1997). Assuming a basin capacity of $66,000 \mathrm{gal} / \mathrm{ft}$, the maximum reduction in level at $3,000 \mathrm{gal} / \mathrm{hr}$ is $1.08 \mathrm{ft} /$ day. Therefore, the time to reach the top of a fuel basket suspended at maximum height is approximately 3 days ( $3.25 \mathrm{ft} / 1.08 \mathrm{ft}$ per day). Access to the area above the south loadout pit or transfer channel will be limited by the direct radiation from the MCO basket fuel as the water coverage decreases. The access time to attempt lowering the grapple before radiation levels are too high is estimated at 2 days. Access to the rest of the basin is possible because of the attenuation by the walls of the transfer channel and south loadout pit (Figures 3-6 and 3-7). Although personnel access will be limited to areas away from the south loadout pit, the 7-day limit to provide makeup water to prevent the other SNF in the basin from being uncovered and eventually recovering the suspended basket is still met.

The annual frequency for the event is estimated as follows. The occurrence of a seismic event has a probability of $2.0 \times 10^{-4}$ per year for $0.2 \mathrm{~g}$ earthquake (DESH 1998b), and the probability of an MCO scrap basket being lifted during MCO loading is $3.81 \times 10^{-3}$ per year, for each facility, using a straightforward engineering calculation. The resulting probability of 
occurrence is $7.61 \times 10^{-7}$, beyond extremely unlikely. ${ }^{1}$ Assumptions for this value are based on the following:

- $\quad$ MCO basket lift time $=10 \mathrm{~min}$

- $\quad \mathrm{MCO}$ scrap baskets per $\mathrm{MCO}=2$ scrap baskets

- $\quad$ MCO loadings per year $=100$ (per basin).

The accident assumptions for the scrap burning are the same as those found in Section 3.4.2.3, "MCO Basket Overlift Accident."

3.4.3.2.2 Source Term Development. The source terms for this accident are the same as those established for the "MCO Basket Overlift Accident" design basis accident in Section 3.4.2.3.2. The respirable source term for this accident is $9.8 \times 10^{2} \mathrm{~g}$.

3.4.3.2.3 Consequence Analysis. The dose for the onsite worker is calculated to be $1.8 \times 10^{3} \mathrm{rem}$ EDE. Doses to all receptors for this scenario are included in Table 3-12.

Table 3-12. Summary of Unmitigated Dose Consequences -Ignition of Scrap Equivalent to 42 Fuel Assemblies (Beyond Design Basis) (Peck 1998).

\begin{tabular}{|l|c|c|}
\hline \multicolumn{1}{|c|}{ Receptor location } & \multicolumn{2}{c|}{ Unmitigated } \\
\cline { 2 - 3 } & $\chi / \mathrm{Q}^{\prime \mathrm{a}}$ & rem EDE (Sv) \\
\hline 100 m east (onsite) & $1.24 \times 10^{-2}$ & $\begin{array}{c}1.8 \times 10^{3} \\
(18)\end{array}$ \\
\hline Hanford Site boundary (12,040 m west) (offsite) & $2.6 \times 10^{-5}$ & $\begin{array}{c}3.8 \\
\left(3.8 \times 10^{-2}\right)\end{array}$ \\
\hline Near river bank (480 m northwest) & $5.5 \times 10^{-4}$ & $\begin{array}{c}80 \\
(0.8)\end{array}$ \\
\hline
\end{tabular}

Notes: ${ }^{8}$ From Table 3B-8 (Peck 1998).

$\mathrm{EDE}=$ effective dose equivalent.

3.4.3.2.4 Comparison to Guidelines. No applicable risk evaluation guidelines have been developed for beyond extremely unlikely events.

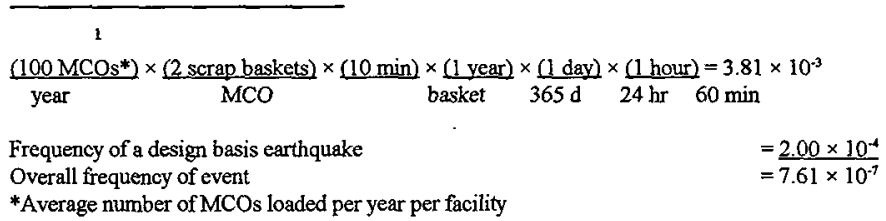


3.4.3.2.5 Summary of Safety-Class SSCs and TSR Controls. Although the unmitigated offsite consequences of this accident exceed the 0.5 rem criteria for the need for safety-class SSC controls, the frequency of the event, $5.7 \times 10^{-7}$, is less than the traditional annual frequency threshold of $1 \times 10^{-6}$ events per year for design basis accidents. Therefore, no safetyclass SSCs controls are required.

This analysis depends on using the operational minimum basin water levels for levels below discharge chute isolation barrier weir height and the weir height if levels are above the weir. The evaluation for the $\mathrm{K}$ West basin bounds that for the $\mathrm{K}$ East Basin. Verifying this level before MCO basket lifts is a candidate for a TSR to support the analysis and its conclusions. Minimum water level is important for operational shielding.

\subsection{REFERENCES}

AIChE, 1992, Guidelines for Hazard Evaluation Procedures, Second Edition with Worked Examples, Center for Chemical Process Safety, American Institute of Chemical Engineers, New York, New York.

Brisbin, S. A., 1997a, Performance Specification for SNF K East and K West MCO Loading System, WHC-S-0546, Rev. 0, DE\&S Hanford, Inc., for Fluor Daniel Hanford, Inc., Richland, Washington.

Brisbin, S. A., 1997b, Design Analysis Report for the TN-WHC Cask and Transportation System, HNF-SD-SNF-FDR-003, Rev. 0, DE\&S Hanford, Inc., for Fluor Daniel Hanford, Inc., Richland, Washington.

Brisbin, S. A., 1997c, Design Review Report for the Hanford $K$ East and $K$ West Basins $M C O$ Loading System, HNF-SD-SNF-DR-004, Rev. 1, DE\&S Hanford, Inc., for Fluor Daniel Hanford, Inc., Richland, Washington.

Chenault, D. M., 1997, Cask Drops onto the K Basin Immersion Pail Support Structure, HNF-1789, DE\&S Hanford, Inc., Rev. 0, including ECN 645074, for Fluor Daniel Hanford, Inc., Richland, Washington.

Chenault, D. M., 1998a, Final Report on the MCO Loading System Shuttle Drop Analysis, HNF-2361, DE\&S Hanford, Inc., for Fluor Daniel Hanford, Inc., Richland, Washington.

Chenault, D. M., 1998b, Final Report on the MCO Loading system Grapple Drop Analysis, HNF-2360, DE\&S Hanford, Inc, for Fluor Daniel Hanford, Inc., Richland, Washington.

Chenault, D. M., 1998c, Drop Analysis of the Loaded Multi-Canister Overpack Transport Cask on the K Basin South Loadout Pit Curb, SNF-2555, DE\&S Hanford, Inc., Richland, Washington. 
Chenault, D. M., 1998d, Cask and Pail Drop Onto the K Basin Immersion Pail Support Structure Bottom Plate, HNF-1897, Rev. 0, including ECN 645075, DE\&S Hanford, Inc., for Fluor Daniel Hanford, Inc., Richland, Washington.

Chenault, D. M., 1998e, Weight Drop on the Shuttle Support Structure, HNF-3032, Rev. 0, DE\&S Hanford, Inc., for Fluor Daniel Hanford, Inc., Richland, Washington.

DESH, 1997, Spent Nuclear Fuel Project Hazard and Safety Assessment, SNF-AP-4-015-00, DE\&S Hanford, Inc., for Fluor Daniel Hanford, Inc., Richland, Washington.

DESH, 1998a, Performance Specification for the Spent Nuclear Fuel Project Multi-Canister Overpack, HNF-S-0426, DE\&S Hanford, Inc., for Fluor Daniel Hanford, Inc., Richland, Washington.

DESH, 1998b, K Basins Safety Analysis Report, WHC-SD-WM-SAR-062, Revision 3D, DE\&S Hanford, Inc., for Fluor Daniel Hanford, Inc., Richland, Washington

DOE, 1994, Airborne Release Fractions/Rates And Respirable Fractions For Nonreactor Nuclear Facilities, DOE-HDBK-3010-94, Vol I, U.S. Department of Energy, Washington, D.C.

DOE Order 5480.21, Unreviewed Safety Questions, U.S. Department of Energy, Washington, D.C.

DOE Order 5480.23, Nuclear Safety Analysis Reports, U.S. Department of Energy, Washington, D.C.

DOE Order 6430.1A, General Design Criteria, U.S. Department of Energy, Washington, D.C.

DOE-STD-1027-92, 1992, Hazard Categorization and Accident Analysis Techniques for Compliance with DOE Order 5480.23, Nuclear Safety Analysis Reports, U.S. Department of Energy, Washington, D.C.

DOE-STD-3009-94, Preparation Guide for U.S. Department of Energy Nonreactor Nuclear Facility Safety Analysis Reports, U.S. Department of Energy, Washington, D.C.

DOE-EM-STD-5502-94, Hazard Baseline Documentation, U.S. Department of Energy, Washington, D.C.

Duncan, D. R., 1998, Assessment for Potential Rapid Oxidation of Submerged N Reactor Fuel, HNF-2786, Rev 0, draft, DE\&S Hanford, Inc., for Fluor Daniel Hanford, Inc., Richland, Washington.

Edwards, W. S., 1998, Safety Analysis Report for Packaging (Onsite) Multi-canister Overpack Cask", HNF-SD-TP-SARP-017, Rev. 1, draft, Waste Management Federal Services, Inc., Northwest Division, for Fluor Daniel Hanford, Inc., Richland, Washington. 
FDNW, 1998, A Discussion on the Methodology for Calculating Radiological and Toxicological Consequences for the Spent Fuel project at the Hanford Site, HNF-SD-SNF-TI-059, Rev. 1, Fluor Daniel Northwest Services, Inc., for Fluor Daniel Hanford, Inc., Richland Washington.

Garvin, L. J., 1997, Spent Nuclear Fuel Project Path Forward Additional NRC Requirements, HNF-SD-SNF-DB-003, Rev. 3, DE\&S Hanford, Inc., for Fluor Daniel Hanford, Inc., Richland, Washington.

Kee, A. T., 1995, Performance Specification for TN-WHC Cask and Transportation System, WHC-S-0396, Rev. 1, Westinghouse Hanford Company, Richland, Washington.

Kee, A. T., 1997a, Analysis of Leakage from $K$ East Fuel Storage Basin, HNF-SD-SNF-ANAL-017, DE\&S Hanford, Inc, for Fluor Daniel Hanford, Inc., Richland, Washington.

Kee, A. T., 1997b, SNF Cask Drop Analysis $K$ Basin Loadout Pits, HNF-SD-SNF-ANAL-020, DE\&S Hanford, Inc., for Fluor Daniel Hanford, Inc., Richland, Washington.

Kessler, S. F., 1998, Criticality Safety Evaluation Report for the Multi-canister Overpack Loading and Handling at the $K$ Basins, HNF-2151, Rev. 1, Fluor Daniel Northwest Services, Inc., for Fluor Daniel Hanford, Inc., Richland, Washington.

Kessler, S. F. and S. H. Peck, 1998, Criticality Safety Evaluation Report for the K Basin Fuel Retrieval Subproject, HNF-SD-SNF-CSER-010, Fluor Daniel Northwest Services, Inc., for Fluor Daniel Hanford, Inc., Richland, Washington.

Lorenz, B. D., 1997, Multicanister Overpack Topical Report, HNF-SD-SNF-SARR-005, Rev. 0, Fluor Daniel Hanford, Inc., Richland, Washington.

Moody, D. A., 1998, Multi-canister Overpack Loading System Anchorage Analysis for $105 \mathrm{KW}$ and 105 KE, HNF-2052, Rev. 0, draft, Fluor Daniel Northwest Services, Inc., for Fluor Daniel Hanford, Inc., Richland, Washington.

Myott, C. F., 1998, Fire Hazard Analysis for the K-Basins Facilities at the $100 \mathrm{~K}$ Area, HNF-SD-SNF-FHA-001, Rev. 1, draft, DE\&S Hanford, Richland, Washington.

Pajunen, A. L., 1998, Spent Nuclear Fuel Project Product Specification, HNF-SD-SNF-OCD-001, Rev. 2, Cogema for Fluor Daniel Hanford, Inc., Richland, Washington.

Peck, S. H., 1998, Fuel Retrieval Sub-Project Safety Analysis Document, HNF-2032, DE\&S Hanford, Inc., for Fluor Daniel Hanford, Inc., Richland, Washington 
Porten, D. R., 1994, K Basins Fuel Encapsulation and Storage Hazard Categorization, WHC-SD-SNF-HC-001, Westinghouse Hanford Company, Richland, Washington.

Porten, D. R., and Crowe, 1994, K Basin Safety Analysis, WHC-SD-SNF-RA-001, Rev. 0, Westinghouse Hanford Company, Richland, Washington.

Praga and Pajunen, 1998, MCO Loading and Cask Loadout Technical Manual, HNF-2169, Rev. A, draft, DE\&S Hanford, Inc., for Fluor Daniel Hanford, Inc., Richland, Washington.

Sellers, E. D., 1997a, Risk Evaluation Guidelines (REG) to Ensure Inherently Safe Designs, DOE/RL-97-SFD-172, transmitted under letter to H. J. Hatch, Fluor Daniel Hanford, Inc., dated August 26, 1997, U.S. Department of Energy, Richland Operations Office, Richland, Washington.

Sellers, E. D., 1997b, Contract No. DE-AC06-96RL13200 - Risk Evaluation Guidelines (Regs) to Ensure Inherently Safer Designs, DOE/RL-97-SFD-034, transmitted under letter no. 9754660 to H. J. Hatch, Fluor Daniel Hanford, Inc., dated May 27, 1997, U.S. Department of Energy, Richland Operations Office, Richland, Washington.

Sellers, E. D., 1997c, Contract No. DE-AC06-96RL13200 - Approval of Critical Decision 3B for the K Basins Facility Upgrades for Cask/Transportation Immersion Pail Support Structure, DOE/RL-97-SFD-195, transmitted under letter no. 9758652 to H. J. Hatch, Fluor Daniel Hanford, Inc., U.S. Department of Energy, Richland Operations Office, Richland, Washington.

Watson, D. J., 1998, K Basins and Cold Vacuum Drying Standards/Requirements Identification Document, HNF-SD-SNF-RD-001, Rev. 0, DE\&S Hanford, Inc., for Fluor Daniel Hanford, Inc., Richland, Washington.

Webb, R. H., 1998a, Hazard/Safety Assessment Supporting Installation of MCO Loading System Equipment and Immersion Pail, HNF-2173, DE\&S Hanford, Inc., for Fluor Daniel Hanford, Inc., Richland, Washington.

Webb, R. H.,1998b, Hazards and Operability Study for SNF CaskMCO Loading System, HNF-2201, DE\&S Hanford; Inc., for Fluor Daniel Hanford, Inc., Richland, Washington.

WHC, 1995, K Basins Environmental Impact Statement Technical Input, WHC-SD-SNF-TI-013, Rev, 0, Westinghouse Hanford Company, Richland, Washington.

Winkel, B. V. and Kanjilal, S. K., 1991, 105-KE/105KW Irradiated Fuel Storage Basin Seismic Qualification, WHC-SD-NR-SA-024, Rev. 0, Westinghouse Hanford Company, Richland, Washington. 
HNF-2456, Rev. 0

Figure 3-1. Hazard Severity Matrix-Offsite Public.

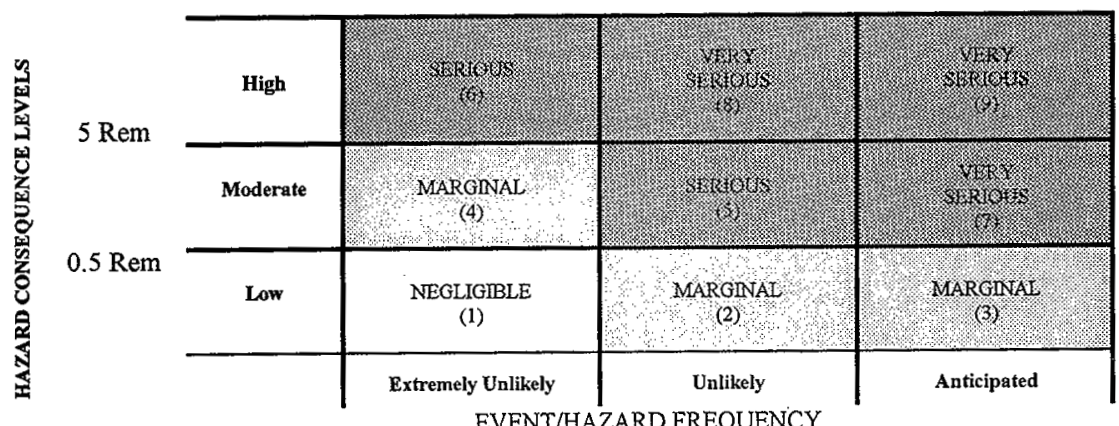

EVENT/HAZARD FREQUENCY

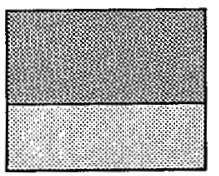

SERIOUS or VERY SERIOUS hazard requiring identification of safety SSCS, and Technical Safety Requirements (nuclear) or Operational Controls (radiological or non-nuclear)

MARGNAL hazard requiring identification of defense-in-depth and/or worker safety SSCs, and operational controls or programmatic requirements

Figure 3-2. Hazard Severity Matrix-Onsite Worker.
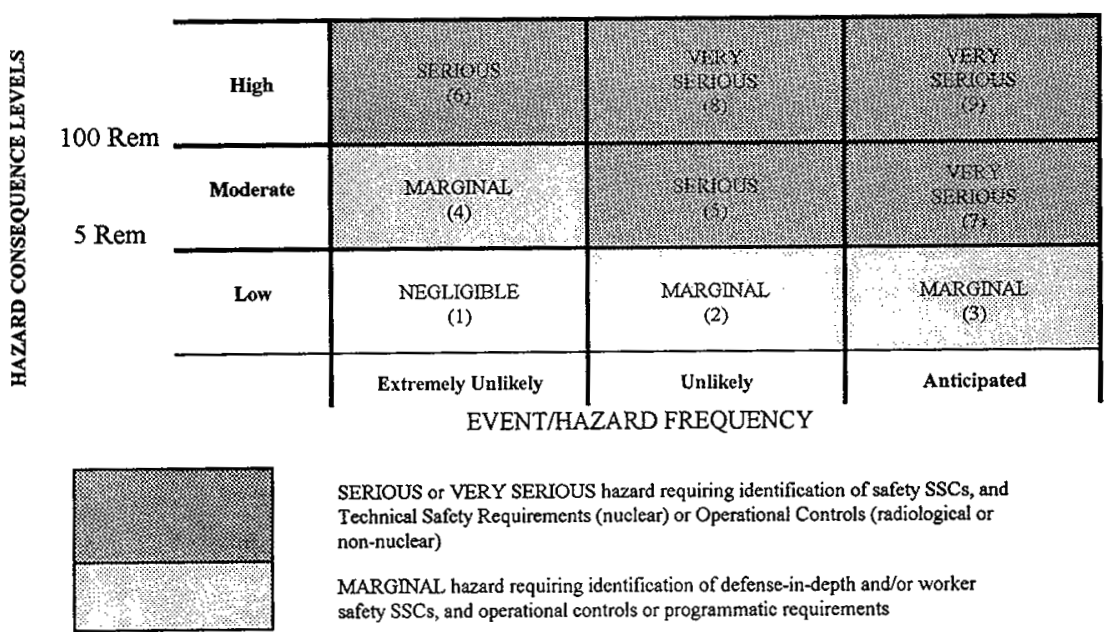

SERIOUS or VERY SERIOUS hazard requiring identification of safety SSCs, and Technical Safety Requirements (nuclear) or Operational Controls (radiological or non-nuclear)

MARGNAL hazard requiring identification of defense-in-depth and/or worker safety SSCs, and operational controls or programmatic requirements 
HNF-2456, Rev. 0

Figure 3-3. Hazard Severity Matrix-Facility Worker.
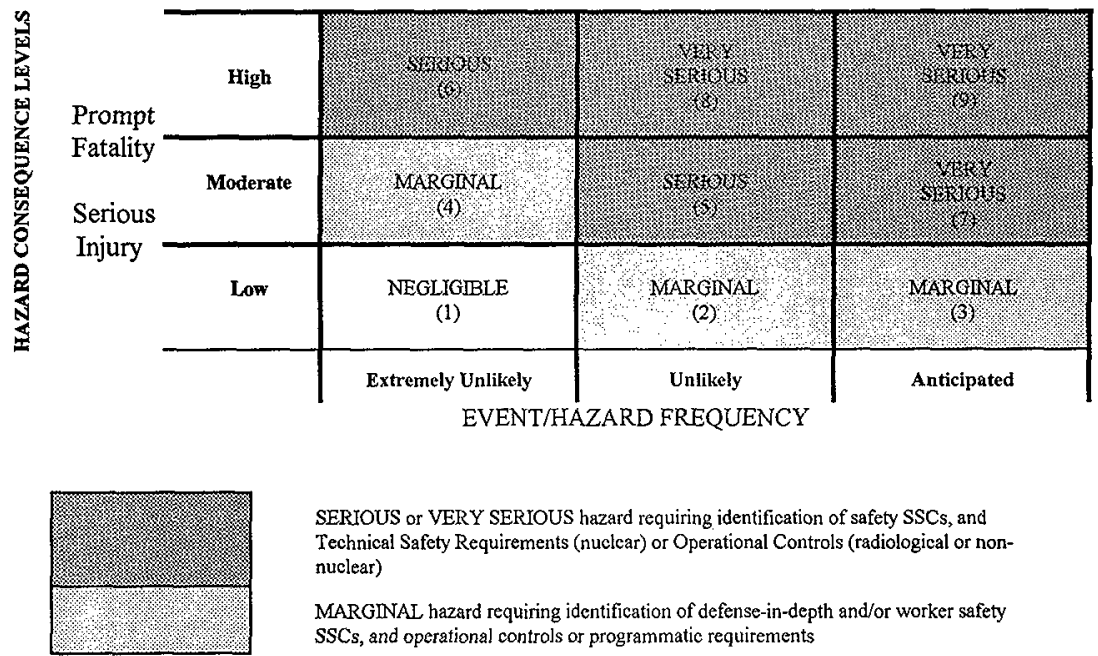

SERIOUS or VERY SERIOUS hazard requiring identification of safety SSCs, and Technical Safety Requirements (nuclear) or Operational Controls (radiological or nonnuclear)

MARGINAI hazard requiring identification of defense-in-depth and/or worker safety SSCs, and operational controls or programmatic requirements 
Figure 3-4. Elevation View of South Loadout Pit and Wall Showing Damage from Cask Impact on Curb.

Elevation View of South Loadout Pit and Wall Damage Due to Cask Impact on Curb

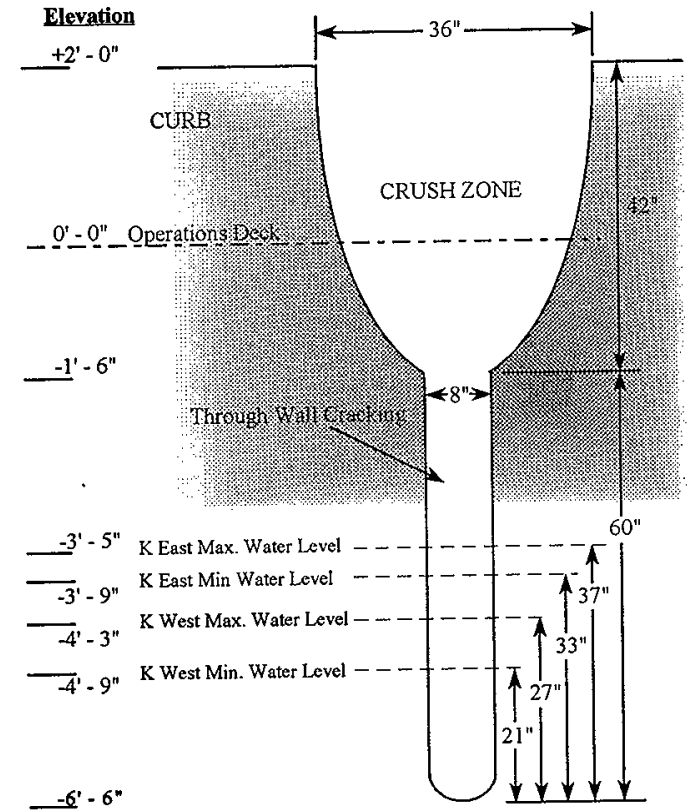


Figure 3-5. Elevation View of MLS.

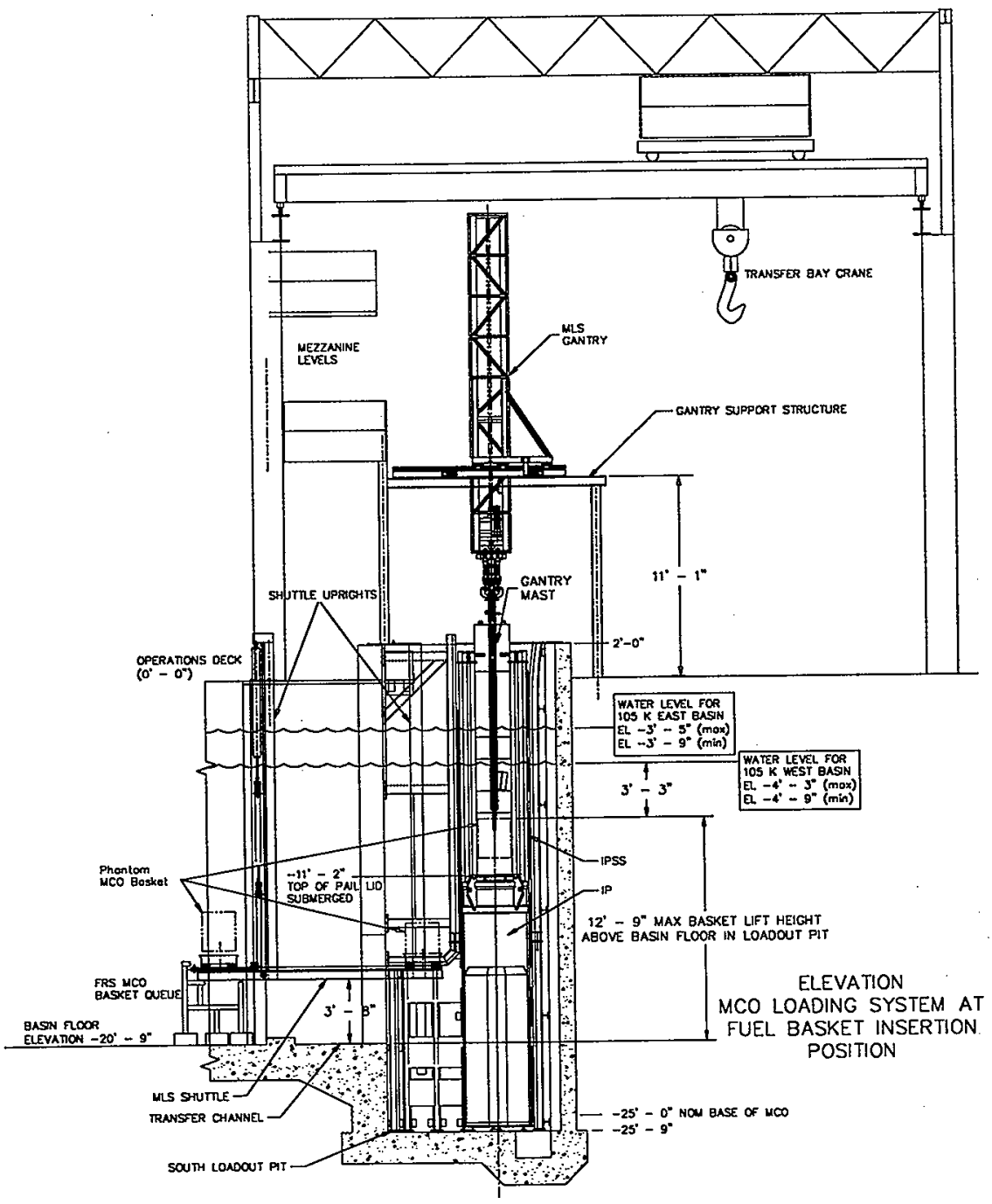


Figure 3-6. Transfer Pit Dose Rate, N-S Cross Section.

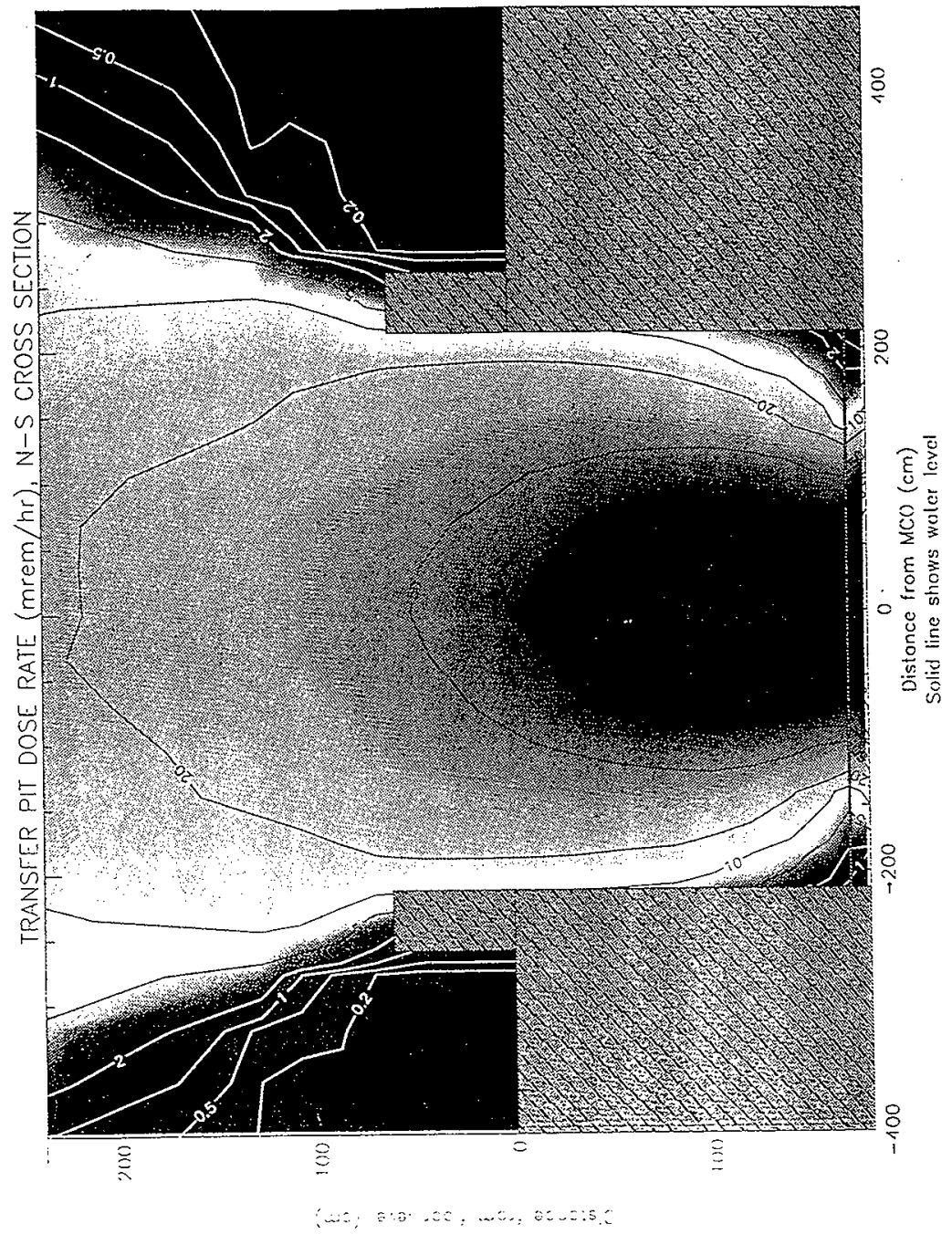


Figure 3-7. Transfer Pit Dose Rate, E-W Cross Section.

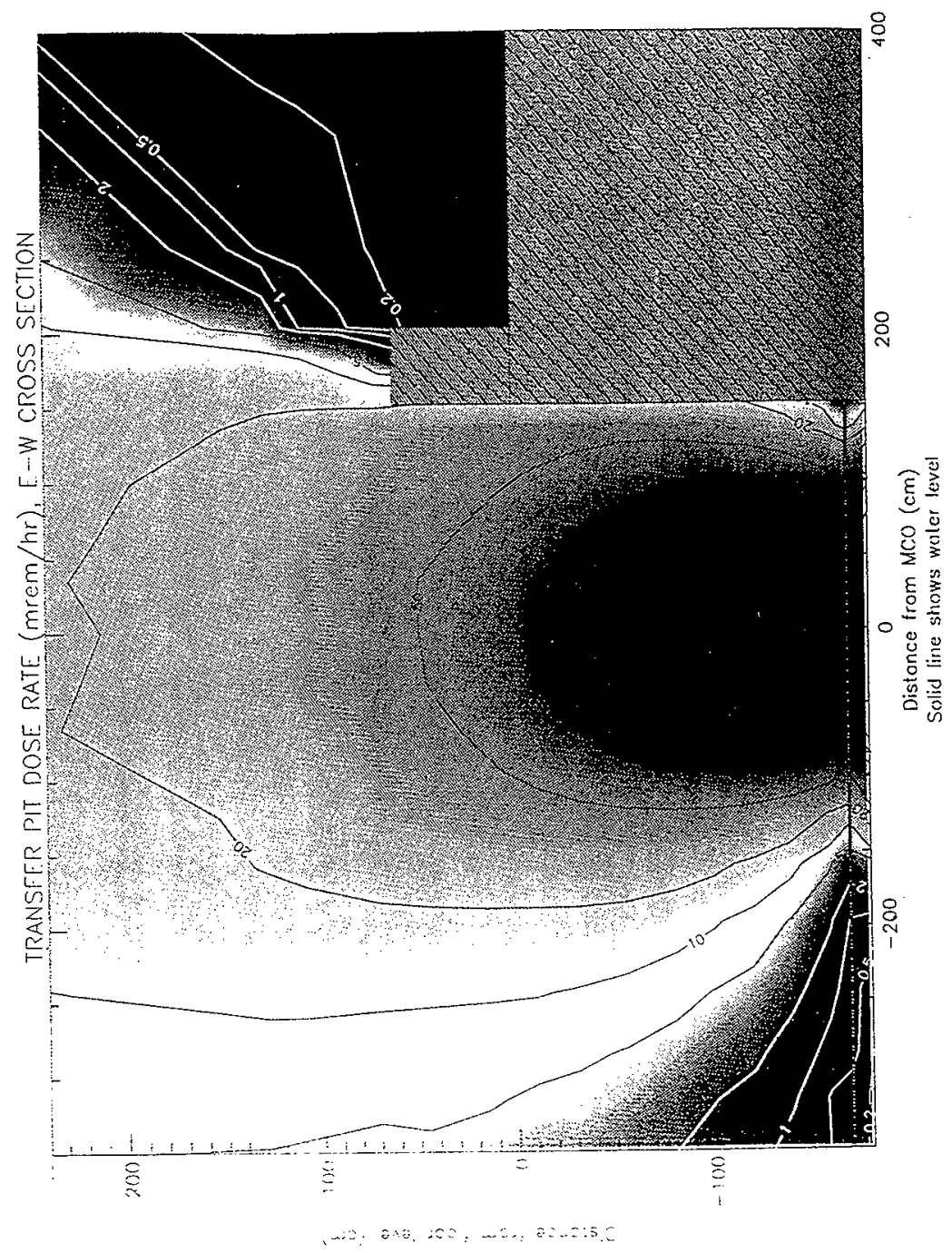


HNF -2456, Rev. 0

\section{APPENDLX 3A}

HAZARD ANALYSIS RESULTS

$3 \mathrm{~A}-1$ 
HNF-2456, Rev. 0

This page left intentionally blank. 
Table 3A-1. Hazards Baseline Checklist for Cask Installation Node. (12 sheets)

\begin{tabular}{|c|c|c|c|c|}
\hline System & $\begin{array}{l}\text { Cask/MCO } \\
\text { Loadout }\end{array}$ & & \multirow[t]{2}{*}{ CI } \\
\hline Node & Cask Installation & & & \\
\hline Type of Hazard & rorm of Hazard & $\mathrm{Y}$ & $\mathrm{N}$ & Description. \\
\hline \multirow{16}{*}{$\begin{array}{l}\text { A. } \\
\text { ELECTRICAL }\end{array}$} & 1. Battery banks & & $\checkmark$ & \\
\hline & 2. Cable runs & $\gamma$ & & SIH \\
\hline & 3. Diesel generators & & $\checkmark$ & \\
\hline & 4. Electrical equipment & 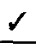 & & SIH \\
\hline & 5. HVAC heaters & & $\checkmark$ & \\
\hline & 6. High voltage & $\checkmark$ & & $\mathrm{SIH}$ \\
\hline & 7. Motors & $\checkmark$ & & SIH \\
\hline & 8. Pumps & $\checkmark$ & & Air monitor equipment - SIH \\
\hline & 9. Power tools & $\checkmark$ & & SIH \\
\hline & 10. Switchgear & $\checkmark$ & & $\mathrm{SIH}$ \\
\hline & $\begin{array}{l}\text { 11. Service outlets, } \\
\text { fittings }\end{array}$ & $\checkmark$ & & SIH \\
\hline & 12. Transformers & $\checkmark$ & & Cask torquing tool - SIH \\
\hline & 13. Transmission lines & & $\checkmark$ & \\
\hline & 14. Underground wires & & $\checkmark$ & \\
\hline & 15. Wiring & $\checkmark$ & & SIH \\
\hline & 16. Other & $\checkmark$ & & $\begin{array}{l}\text { General power failure (event) (CI-G-3f/CI-R-1 } \\
\text { and 3) }\end{array}$ \\
\hline \multirow[t]{5}{*}{$\begin{array}{l}\text { B. } \\
\text { THERMAL }\end{array}$} & $\begin{array}{l}\text { 1. Bunsen burner/hot } \\
\text { plates }\end{array}$ & & $\sqrt{a}$ & \\
\hline & 2. Electrical equipment & & $\checkmark$ & \\
\hline & $\begin{array}{l}\text { 3. Furnaces/boilers/ } \\
\text { heater }\end{array}$ & & $\checkmark$ & \\
\hline & 4. Steam lines & & 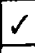 & \\
\hline & 5. Welding torch/arc & & $\checkmark$ & \\
\hline
\end{tabular}


Table 3A-1, Hazards Baseline Checklist for Cask Installation Node. (12 sheets)

\begin{tabular}{|c|c|c|c|c|c|}
\hline System & $\begin{array}{l}\text { Cask/MCO } \\
\text { Loadout }\end{array}$ & & & & CI \\
\hline Node & Cask Installation & & & & \\
\hline Iype or hazard & form of Hazard & 1 & $\mathrm{~N}$ & Description & 2 \\
\hline \multirow[t]{8}{*}{$\begin{array}{l}\text { B. } \\
\text { THERMAL }\end{array}$} & $\begin{array}{l}\text { 6. Diesel units/fire } \\
\text { box/exhaust line }\end{array}$ & $\checkmark$ & & exhaust lines - SIH (also FHA) & . \\
\hline & $\begin{array}{l}\text { 7. Radioactive decay } \\
\text { heat }\end{array}$ & & $\checkmark$ & & \\
\hline & 8. Exposed components & & $\checkmark$ & & \\
\hline & 9. Power tools & & $\checkmark$ & & \\
\hline & 10. Convective & & 6 & & \\
\hline & 11. Solar & & $\checkmark$ & & \\
\hline & 12. Cryogenic & & $\checkmark$ & & \\
\hline & 13. Other & & $\checkmark$ & & \\
\hline \multirow{7}{*}{$\begin{array}{l}\text { C. } \\
\text { FRICTION }\end{array}$} & 1. Belts & $\checkmark$ & & $\mathrm{SIH}$ & \\
\hline & 2. Bearings & $\checkmark$ & & SIH & \\
\hline & 3. Fans & & $\checkmark$ & & \\
\hline & 4. Gears & $\checkmark$ & & SIH & \\
\hline & 5. Motors & $\checkmark$ & & SIH & \\
\hline & 6. Power tools & & $\checkmark$ & & \\
\hline & 7. Other & & $\checkmark$ & & \\
\hline \multirow{6}{*}{$\begin{array}{l}\text { D. } \\
\text { CORROSIVES }\end{array}$} & 1. Acids & & $r$ & & \\
\hline & 2. Caustics & & $\checkmark$ & & \\
\hline & 3. Natural chemicals & & $\checkmark$ & & \\
\hline & 4. Decon solution & $r$ & & $\mathrm{SIH}$. & \\
\hline & $\begin{array}{l}\text { 5. High temperature } \\
\text { waste }\end{array}$ & & $\checkmark$ & & \\
\hline & 6. Other & & $\checkmark$ & & \\
\hline
\end{tabular}


Table 3A-1. Hazards Baseline Checklist for Cask Installation Node. (12 sheets)

\begin{tabular}{|c|c|c|c|c|}
\hline System & $\begin{array}{l}\text { Cask/MCO } \\
\text { Loadout }\end{array}$ & & & \\
\hline Node & Cask Installation & & & \\
\hline Type or Hazard & Form of Fazard & $y$ & N. & Description \\
\hline \multirow{7}{*}{$\begin{array}{l}\text { E. } \\
\text { KINETIC - } \\
\text { ROTATIONAL }\end{array}$} & 1. Centrifuges & & $\checkmark$ & \\
\hline & 2. Motors & $\checkmark$ & & SIH \\
\hline & 3. Pumps & & $\checkmark$ & \\
\hline & 4. Cooling tower fans & & $\checkmark$ & \\
\hline & 5. Laundry equipment & & $\checkmark$ & \\
\hline & 6. Shop equipment & $\checkmark$ & & Air operated equipment (Trailer landing gear) SIH \\
\hline & 7. Other & & $\checkmark$ & . \\
\hline \multirow[t]{7}{*}{$\begin{array}{l}\text { F. } \\
\text { KINETIC - } \\
\text { LINEAR }\end{array}$} & 1. Cars, trucks, buses & $\checkmark$ & & $\begin{array}{l}\text { a. trailer and truck backs into bumper protecting } \\
\text { basin } \\
\text { b. trailer and truck back into gantry structure } \\
\text { c. trailer and truck back into SLOP curb }\end{array}$ \\
\hline & $\begin{array}{l}\text { 2. Forklifts, dollies, } \\
\text { carts }\end{array}$ & $\checkmark$ & & $\begin{array}{l}\text { torque device cart - SIH } \\
\text { hand carts - SIH }\end{array}$ \\
\hline & 3. Railroad & & $\checkmark$ & \\
\hline & 4. Obstructions & $\checkmark$ & & $\begin{array}{l}\text { Walls, loadout pit curb, gantry structure, cask, } \\
\text { truck. Also laydown areas. (CI-F-I/CI-F-5) }\end{array}$ \\
\hline & 5. Crane loads & $\checkmark$ & & $\begin{array}{l}\text { a. gantry is struck by cask while unloaded } \\
\text { cask/MCO is being installed into the SLOP } \\
\text { b. transfer bay crane load strikes SLOP curb in a } \\
\text { linear direction while installing unloaded } \\
\text { cask/MCO } \\
\text { c. transfer bay crane hook catches gantry structure } \\
\text { during operations }\end{array}$ \\
\hline & $\begin{array}{l}\text { 6. Pressure vessel } \\
\text { blowdown }\end{array}$ & & $\checkmark$ & \\
\hline & 7. Other & & $\checkmark$ & \\
\hline
\end{tabular}


Table 3A-1. Hazards Baseline Checklist for Cask Installation Node. (12 sheets)

\begin{tabular}{|c|c|c|c|c|}
\hline System & $\begin{array}{l}\text { Cask/MCO } \\
\text { Loadout }\end{array}$ & & & \\
\hline Node & Cask Installation & & & \\
\hline Type of Hazard & form o l Hazard & $y$ & $\mathrm{~N}$ & 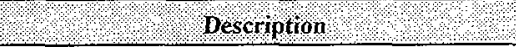 \\
\hline \multirow{12}{*}{$\begin{array}{l}\text { G. } \\
\text { MASS, GRAVITY, } \\
\text { HEIGHT }\end{array}$} & 1. Human effort & $\checkmark$ & & Moving carts - SIH \\
\hline & 2. Stairs & $\checkmark$ & & SIH \\
\hline & 3. Lifts and cranes & $\checkmark$ & & $\begin{array}{l}\text { a. transfer bay crane is overloaded during lift of } \\
\text { cask/MCO as a result of cask/MCO still being } \\
\text { tied down to trailer } \\
\text { b. transfer bay crane drops unloaded cask/MCO } \\
\text { directly onto SLOP curb } \\
\text { c. transfer bay crane drops unloaded cask/MCO } \\
\text { tip-and-hit on SLOP curb } \\
\text { d. transfer bay crane drops unloaded cask/MCO } \\
\text { into immersion pail which is locked in the } \\
\text { upper position from a position just above the } \\
\text { SLOP curb } \\
\text { e. transfer bay crane drops unloaded } \\
\text { IP/cask/MCO from top IPSS position onto } \\
\text { IPSS bottom plate } \\
\text { f. transfer bay crane is affected by general power } \\
\text { failure event (CI-A-16) }\end{array}$ \\
\hline & 4. Bucket and ladder & & $\checkmark$ & \\
\hline & 5. Trucks & & $\checkmark$ & \\
\hline & 6. Slings & $\checkmark$ & & $\begin{array}{l}\text { Slings used to lower IP/cask/MCO into SLOP. } \\
\text { Scenario bounded by CI-G-3d. }\end{array}$ \\
\hline & 7. Hoists & $\checkmark$ & & $\mathrm{SIH}$ \\
\hline & 8. Elevators & & $\checkmark$ & \\
\hline & 9. Jacks & $\checkmark$ & & $\begin{array}{l}\text { trailer jacks fail while cask/MCO is in transfer bay } \\
\text { and takes out critical structural members }\end{array}$ \\
\hline & 10. Scaffold and ladders & $\checkmark$ & & SIH \\
\hline & 11. Pits and excavations & $\checkmark$ & & $\mathrm{SIH}$ \\
\hline & 12. Elevated doors & $\checkmark$ & & Roll-up doors - SIH \\
\hline \multirow{2}{*}{$\begin{array}{l}\text { G. } \\
\text { MASS, GRAVITY, } \\
\text { HEIGHT (cont) }\end{array}$} & 13. Vessels & $\checkmark$ & & cask/MCO (CI-G-3) \\
\hline & 14. Other & $\checkmark$ & & Temporary shielding \\
\hline
\end{tabular}


Table 3A-1. Hazards Baseline Checklist for Cask Installation Node. (12 sheets)

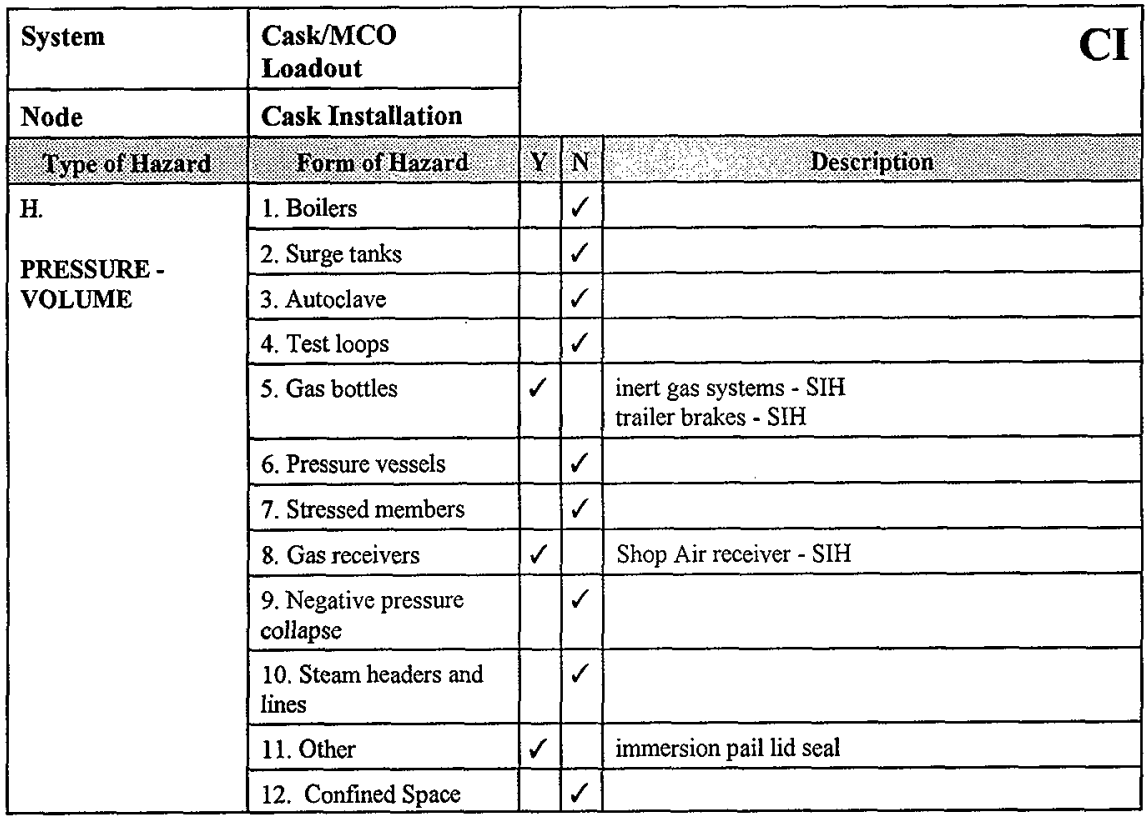


Table 3A-1. Hazards Baseline Checklist for Cask Installation Node. (12 sheets)

\begin{tabular}{|c|c|c|c|}
\hline System & $\begin{array}{l}\text { Cask/MCO } \\
\text { Loadout }\end{array}$ & & CI \\
\hline Node & Cask Installation & & \\
\hline Type of Hazard & Form of Hazard & $\mathrm{YN}$ & Description \\
\hline \multirow{6}{*}{$\begin{array}{l}\text { J. } \\
\text { EXPLOSIVES/ } \\
\text { PYROPHORICS }\end{array}$} & 1. Caps & $\checkmark$ & \\
\hline & 2. Primer cord & $\checkmark$ & \\
\hline & 3. Dynamite & $\checkmark$ & \\
\hline & 4. Scrub chemicals & $\checkmark$ & \\
\hline & 5. Dusts & $\checkmark$ & \\
\hline & 6. Hydrogen & $\checkmark$ & \\
\hline \multirow[t]{6}{*}{. } & 7. Gases, other & $\checkmark$ & \\
\hline & 8. Nitrates & $\checkmark$ & \\
\hline & 9. Peroxides & $r$ & \\
\hline & 10. $\mathrm{Pu}$ and $\mathrm{U}$ metal & $\checkmark$ & \\
\hline & 11. Sodium & $\checkmark$ & \\
\hline & 12. Other & $\checkmark$ & \\
\hline
\end{tabular}


Table 3A-1. Hazards Baseline Checklist for Cask Installation Node. (12 sheets)

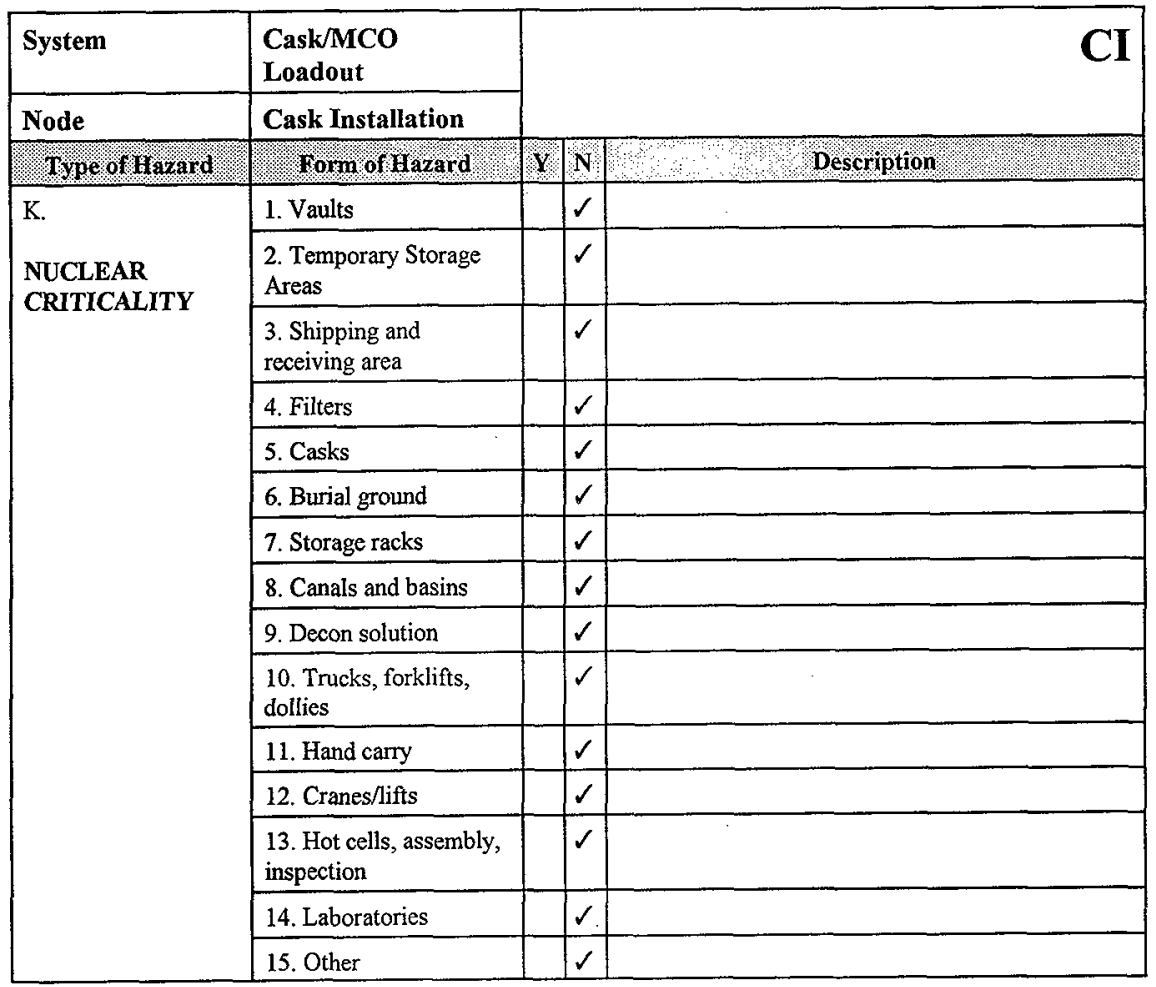


Table 3A-1. Hazards Baseline Checklist for Cask Installation Node. (12 sheets)

\begin{tabular}{|c|c|c|c|c|}
\hline System & $\begin{array}{l}\text { Cask/MCO } \\
\text { Loadout }\end{array}$ & & & CI \\
\hline Node & Cask Installation & & & \\
\hline IYpe of Hazard & Iorm or Hazard & Y. & $\mathrm{N}$ & Description \\
\hline \multirow{16}{*}{$\begin{array}{l}\text { L. } \\
\text { FLAMMABLE } \\
\text { MATERIALS } \\
\text { Note: These are } \\
\text { covered by FHA }\end{array}$} & 1. Packing materials & & $\checkmark$ & \\
\hline & 2. Rags & & $\checkmark$ & \\
\hline & 3. Gasoline & & $\checkmark$ & \\
\hline & 4. Lube oil & $\checkmark$ & & SIH (Truck) \\
\hline & 5. Coolant oil & $\checkmark$ & & SIH (Truck) \\
\hline & 6. Paint solvent & & $\checkmark$ & \\
\hline & 7. Diesel fuel & $\checkmark$ & & SIH (Truck) \\
\hline & 8. Buildings \& contents & $\checkmark$ & & \\
\hline & 9. Trailers and contents & $\checkmark$ & & Grease, Tires - FHA \\
\hline & 10. Grease & $\checkmark$ & & Grease, Tires - FHA \\
\hline & 11. Hydrogen & & $\checkmark$ & \\
\hline & 12. Nitric acid & & $\checkmark$ & \\
\hline & 13. Organics & & $r$ & \\
\hline & 14. Gases - others & & $r$ & \\
\hline & 15. Liquids - others & & $\checkmark$ & \\
\hline & 16. Other & & $\checkmark$ & \\
\hline
\end{tabular}


Table 3A-1. Hazards Baseline Checklist for Cask Installation Node. (12 sheets)

\begin{tabular}{|c|c|c|c|c|}
\hline System & $\begin{array}{l}\text { Cask/MCO } \\
\text { Loadout }\end{array}$ & & & CI \\
\hline Node & Cask Installation & & & \\
\hline Type of Hazard & Form of Hazard: & $y$ & $N$ & Description \\
\hline $\mathrm{M}$ & 1. Alkali metals & & $\checkmark$ & \\
\hline HAZARDOUS & 2. Asphyxiants & 6 & & Diesel Exhaust - SIH \\
\hline MATERIALS & 3. Biologicals & $\checkmark$ & & Spiders - SIH \\
\hline & 4. Carcinogens & $\checkmark$ & & Diesel Exhaust - SIH \\
\hline & 5. Corrosives & $\checkmark$ & & Battery Truck Acid - SIH \\
\hline & 6. Oxidizers & $r$ & & Decon agents - SIH \\
\hline & 7. Toxics & $\checkmark$ & & Antifreeze - SIH \\
\hline & 8. Heavy metals & $r$ & & Temp shielding - SIH \\
\hline & 9. Other & & $\checkmark$ & \\
\hline N. & 1. Fissile material & & $\checkmark$ & \\
\hline $\begin{array}{l}\text { IONIZING } \\
\text { RADIATION }\end{array}$ & $\begin{array}{l}\text { 2. Radiography } \\
\text { equipment }\end{array}$ & & $\checkmark$ & \\
\hline $\begin{array}{l}\text { SOURCES } \\
\text { SOU }\end{array}$ & 3. Radioactive material & $\checkmark$ & & $\begin{array}{l}\text { potential splash during installation - SIH } \\
\text { Surface contamination - SIH } \\
\text { Airborne contamination - SIH }\end{array}$ \\
\hline & 4. Radioactive sources & & $\checkmark$ & \\
\hline & 5. Other & & $\checkmark$ & \\
\hline P. & 1. Explosion & 6 & & Trucks outside building - SIH \\
\hline EXTERNAL & 2. Fire & 6 & & Trucks outside building - SIH \\
\hline EVENTS & 3. Other sites & & $\checkmark$ & \\
\hline Q. & 1. Airplanes & $\checkmark$ & & Covered by SAR \\
\hline VEHICLES IN & 2. Helicopter & $\checkmark$ & & Covered by SAR \\
\hline MOTION (external & 3. Train & $\checkmark$ & & Covered by SAR \\
\hline & 4. Truck/bus /car & $\checkmark$ & & Covered by SAR \\
\hline & 5. Other - Fork lifts & $\checkmark$ & & Covered by sitting criteria \\
\hline
\end{tabular}


Table 3A-1. Hazards Baseline Checklist for Cask Installation Node. (12 sheets)

\begin{tabular}{|c|c|c|c|c|}
\hline System & $\begin{array}{l}\text { Cask/MCO } \\
\text { Loadout }\end{array}$ & & & \multirow[t]{2}{*}{ CI } \\
\hline Node & Cask Installation & & & \\
\hline Type of Hazard & Tormu of Hazard & Y & $\mathrm{N}$ & Description \\
\hline \multirow[t]{10}{*}{$\begin{array}{l}\text { R. } \\
\text { NATURAL } \\
\text { PHENOMENA }\end{array}$} & 1. Earthquake & $\checkmark$ & & $\begin{array}{l}\text { a. seismic forces exerted on the IPSS transmits } \\
\text { excessive force to the SLOP walls } \\
\text { b. Initiating event of a general power failure } \\
\text { (Cl-A-16) } \\
\text { Note: No need to analyze locking ring on aux hoist; } \\
\text { cask drops bounds }\end{array}$ \\
\hline & 2. Flood & & $\checkmark$ & N/A-- Above Flood Plain \\
\hline & 3. Lightning & $\checkmark$ & & $\begin{array}{l}\text { Initiating event of a general power failure (Cl-A- } \\
\text { 16) }\end{array}$ \\
\hline & 4. Rain & & $\checkmark$ & \\
\hline & $\begin{array}{l}\text { 5. Snow, freezing } \\
\text { weather }\end{array}$ & & $\checkmark$ & \\
\hline & 6. Straight wind & $\checkmark$ & & $\begin{array}{l}\text { SIH (Windbreak to further precludes contamination } \\
\text { spread) }\end{array}$ \\
\hline & 7. Dust devil & & $\checkmark$ & \\
\hline & 8. Tornado & & $\checkmark$ & Grandfathered - non reactor facility \\
\hline & 9. Ashfall & & $\checkmark$ & \\
\hline & 10. Range fire & & $\checkmark$ & \\
\hline
\end{tabular}


Table 3A-2. Hazard Baseline Checklist for MCO Load Node. (11 sheets.)

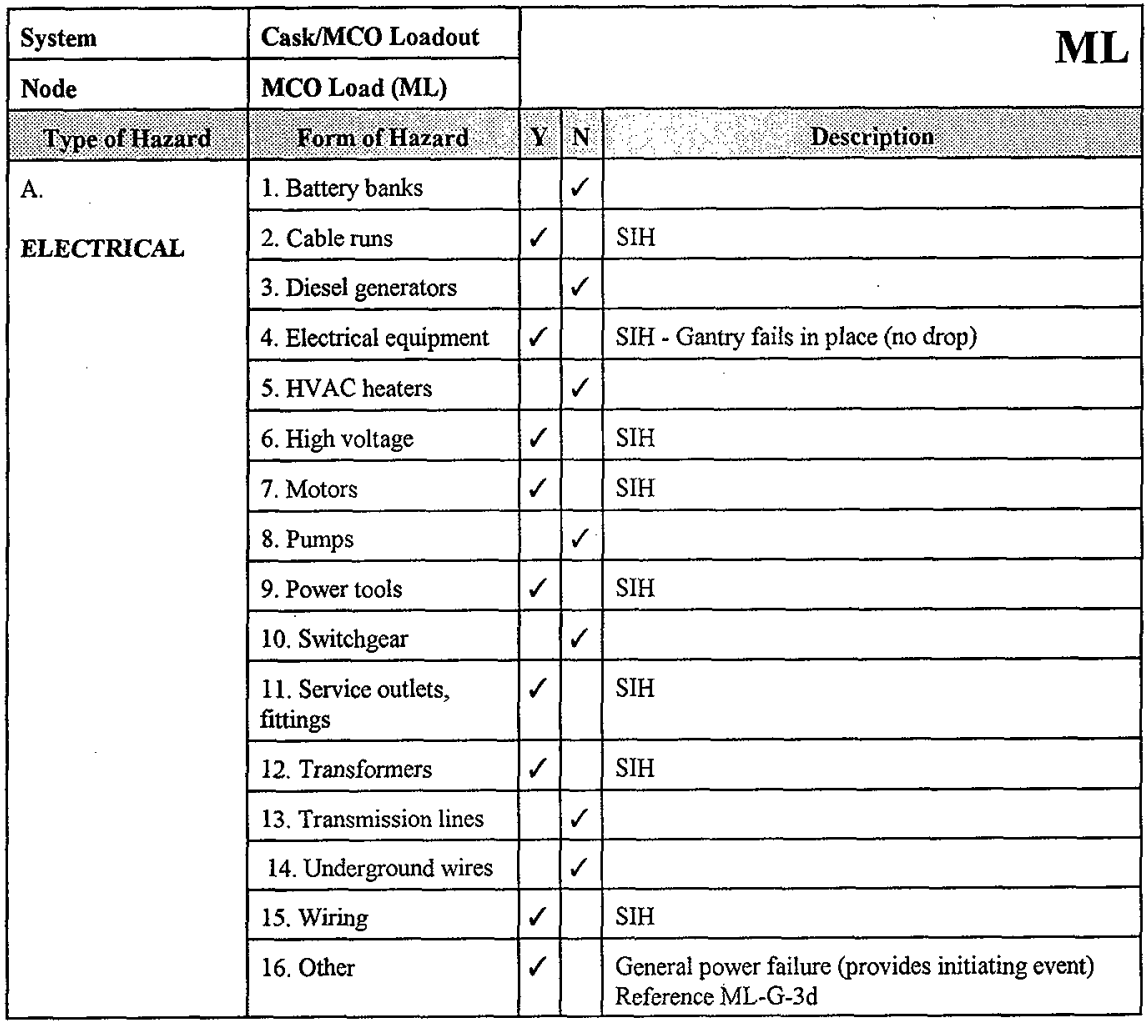


Table 3A-2. Hazard Baseline Checklist for MCO Load Node. (11 sheets.)

\begin{tabular}{|c|c|c|c|c|}
\hline System & Cask/MCO Loadout & \multirow{2}{*}{\multicolumn{3}{|c|}{$\mathbf{M L}$}} \\
\hline Node & MCO Load (ML) & & & \\
\hline Type of Hazard & Form of Hazard & $Y$ & $\mathbf{N}$ & Description \\
\hline \multirow{13}{*}{$\begin{array}{l}\text { B. } \\
\text { THERMAL }\end{array}$} & $\begin{array}{l}\text { 1. Bunsen burner/hot } \\
\text { plates }\end{array}$ & & $\checkmark$ & \\
\hline & 2. Electrical equipment & & $\checkmark$ & \\
\hline & $\begin{array}{l}\text { 3. Furnaces/ } \\
\text { boilers/ heater }\end{array}$ & & $\checkmark$ & \\
\hline & 4. Steam lines & & $\checkmark$ & \\
\hline & 5. Welding torch/arc & & $\checkmark$ & \\
\hline & $\begin{array}{l}\text { 6. Diesel units/fire box/ } \\
\text { exhaust line }\end{array}$ & & $\checkmark$ & \\
\hline & $\begin{array}{l}\text { 7. Radioactive decay } \\
\text { heat }\end{array}$ & $\checkmark$ & & $\begin{array}{l}\text { Not an issue because decay heat is fairly low, basin } \\
\text { water provides heat sink, and MCO topical covers } \\
\text { decay heat. }\end{array}$ \\
\hline & 8. Exposed components & & $\checkmark$ & \\
\hline & 9. Power tools & & $\checkmark$ & \\
\hline & 10. Convective & & $r$ & \\
\hline & 11. Solar & & $r$ & \\
\hline & 12. Cryogenic & & $r$ & \\
\hline & 13. Other & & $\checkmark$ & \\
\hline \multirow{7}{*}{$\begin{array}{l}\text { C. } \\
\text { FRICTION }\end{array}$} & 1. Belts & $\checkmark$ & & SIH - gantry \\
\hline & 2. Bearings & $\checkmark$ & 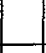 & $\mathrm{SIH}$ \\
\hline & 3. Fans & & $\checkmark$ & \\
\hline & 4. Gears & $\checkmark$ & & $\mathrm{SIH}$ \\
\hline & 5. Motors & $\checkmark$ & & $\mathrm{SIH}$ \\
\hline & 6. Power tools & & $\checkmark$ & \\
\hline & 7. Cables & $\checkmark$ & & Shuttle - not an issue \\
\hline
\end{tabular}


Table 3A-2. Hazard Baseline Checklist for MCO Load Node. (11 sheets.)

\begin{tabular}{|c|c|c|c|c|}
\hline System & Cask/MCO Loadout & \multirow{2}{*}{\multicolumn{3}{|c|}{$\mathbf{M L}$}} \\
\hline Node & MCO Load (ML) & & & \\
\hline Iype of Hazard & Form or Hazard & $y$ & $\mathrm{~N}$ & Description \\
\hline \multirow{6}{*}{$\begin{array}{l}\text { D. } \\
\text { CORROSIVES }\end{array}$} & 1. Acids & & $\checkmark$ & \\
\hline & 2. Caustics & & $\checkmark$ & \\
\hline & 3. Natural chemicals & & $\checkmark$ & \\
\hline & 4. Decon solution & & $\checkmark$ & \\
\hline & $\begin{array}{l}\text { 5. High temperature } \\
\text { waste }\end{array}$ & & $\checkmark$ & \\
\hline & 6. Other & & $\checkmark$ & \\
\hline \multirow{7}{*}{$\begin{array}{l}\text { E. } \\
\text { KINETIC- } \\
\text { ROTATIONAL }\end{array}$} & 1. Centrifuges & & $\checkmark$ & \\
\hline & 2. Motors & $\checkmark$ & & SIH \\
\hline & 3. Pumps & & 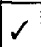 & \\
\hline & 4. Cooling tower fans & & $\checkmark$ & \\
\hline & 5. Laundry equipment & & $\checkmark$ & \\
\hline & 6. Shop equipment & $\checkmark$ & & Gantry shaft - SIH \\
\hline & 7. Other & & $\checkmark$ & \\
\hline
\end{tabular}


Table 3A-2. Hazard Baseline Checklist for MCO Load Node. (11 sheets.)

\begin{tabular}{|c|c|c|c|c|}
\hline System & Cask/MCO Loadout & & & \multirow{2}{*}{$\mathbf{M L}$} \\
\hline Node & MCO Load (ML) & & & \\
\hline Type of Hazard. & Form of Hazard & Y & $\mathrm{N}$ & Description \\
\hline \multirow{7}{*}{$\begin{array}{l}\text { F. } \\
\text { KINETIC - } \\
\text { LINEAR }\end{array}$} & 1. Cars, trucks, buses & & $\checkmark$ & \\
\hline & $\begin{array}{l}\text { 2. Forklifts, dollies, } \\
\text { carts }\end{array}$ & $\checkmark$ & & $\begin{array}{l}\text { Cart - MLS shuttle. Cart movement is slow and } \\
\text { there is no significant kinetic energy to result in a } \\
\text { hazard. }\end{array}$ \\
\hline & 3. Railroad & & $\checkmark$ & \\
\hline & 4. Obstructions & $\checkmark$ & & $\begin{array}{l}\text { a. While a basket (of fuel or scrap) is being lifted } \\
\text { into MCO, the basket catches the edge of the } \\
\text { immersion pail lid (and/or guide funnel), and } \\
\text { spills into the MCO. } \\
\text { b. While a basket (of fuel or scrap) is being lifted } \\
\text { into MCO, the basket isn't lifted high enough } \\
\text { and the basket hits the immersion pail support } \\
\text { structure or immersion pail during loading. } \\
\text { c. Dip tube catch SLOP curb - not enough kinetic } \\
\text { energy to be an issue }\end{array}$ \\
\hline & 5. Crane loads & $\checkmark$ & & $\begin{array}{l}\text { Dip tube catch SLOP curb - not enough kinetic } \\
\text { energy to be an issue }\end{array}$ \\
\hline & $\begin{array}{l}\text { 6. Pressure vessel } \\
\text { blowdown }\end{array}$ & & $\checkmark$ & \\
\hline & 7. Other & & $\checkmark$ & \\
\hline
\end{tabular}


Table 3A-2. Hazard Baseline Checklist for MCO Load Node. (11 sheets.)

\begin{tabular}{|c|c|c|c|c|}
\hline System & Cask/MCO Loadout & & & \multirow{2}{*}{$\mathbf{M L}$} \\
\hline Node & MCO Load (ML) & & & \\
\hline 1,pe or Hazard & Gorm of Hazard & y & $\mathrm{N}$ & Description \\
\hline \multirow{14}{*}{$\begin{array}{l}\text { G. } \\
\text { MASS, GRAVITY, } \\
\text { HEIGHT }\end{array}$} & 1. Human effort & $\checkmark$ & & Loading fuel baskets, lid assembly - SIH \\
\hline & 2. Stairs & $\checkmark$ & & $\mathrm{SHH}$ \\
\hline & 3. Lifts and cranes & $\checkmark$ & & $\begin{array}{l}\text { a. basket is dropped onto shuttle during loading } \\
\text { operations } \\
\text { b. basket is lifted too high (creates higher dose to } \\
\text { worker or is lifted out of the water) (See also } \\
\text { ML-N-3a and ML-J-10/ML-R-lb) } \\
\text { c. general power failure initiatiating event affects } \\
\text { gantry during basket loading (ML-R-1b) } \\
\text { d. dip tube does not properly seat during shield } \\
\text { plug installation } \\
\text { e. lid, shield plug lifts - SIH (insufficient mass to } \\
\text { crack walls on floors) }\end{array}$ \\
\hline & 4. Bucket and ladder & & $\checkmark$ & \\
\hline & 5. Trucks & & $\checkmark$ & \\
\hline & 6. Slings & & $\checkmark$ & \\
\hline & 7. Hoists & $\checkmark$ & & Aux hoists, not a nuclear hazard- SIH (ML-G-3e) \\
\hline & 8. Elevators & & $\checkmark$ & \\
\hline & 9. Jacks & & $\checkmark$ & \\
\hline & 10. Scaffold and ladders & & $\checkmark$ & \\
\hline & 11. Pits and excavations & $\checkmark$ & & Loadout pit - SIH \\
\hline & 12. Elevated doors & & $\checkmark$ & \\
\hline & 13. Vessels & & $\checkmark$ & \\
\hline & 14. Other ball screw & $\checkmark$ & & Reference ML-G-3b above \\
\hline
\end{tabular}


Table 3A-2. Hazard Baseline Checklist for MCO Load Node. (11 sheets.)

\begin{tabular}{|c|c|c|c|c|}
\hline System & Cask/MCO Loadout & \multirow{2}{*}{\multicolumn{3}{|c|}{$\mathbf{M L}$}} \\
\hline Node & MCO Load (ML) & & & \\
\hline Type of Hazard & Eorm of Hazard & 1 & $N$ & Description: \\
\hline \multirow{12}{*}{$\begin{array}{l}\text { H. } \\
\text { PRESSURE - } \\
\text { VOLUME }\end{array}$} & 1. Boilers & & $\checkmark$ & \\
\hline & 2. Surge tanks & & $\checkmark$ & \\
\hline & 3. Autoclave & & $\checkmark$ & \\
\hline & 4. Test loops & & $\checkmark$ & \\
\hline & 5. Gas bottles & & $\checkmark$ & \\
\hline & 6. Pressure vessels & $\checkmark$ & & $\begin{array}{l}\text { At least } 1 \text { pressure valve is to be open in the shield } \\
\text { plug so that the cask/MCO atmospheres can } \\
\text { communicate during transport to CVDF. } \\
\text { MCO topical covers MCO as a pressure vessel } \\
\text { once shield plug is installed. }\end{array}$ \\
\hline & 7. Stressed members & & $\checkmark$ & \\
\hline & 8. Gas receivers & & 8 & \\
\hline & $\begin{array}{l}\text { 9. Negative pressure } \\
\text { collapse }\end{array}$ & & $\checkmark$ & \\
\hline & $\begin{array}{l}\text { 10. Steam headers and } \\
\text { lines }\end{array}$ & & $\checkmark$ & \\
\hline & 11. Other & & $\checkmark$ & \\
\hline & 12. Confined space & & $\checkmark$ & \\
\hline
\end{tabular}


Table 3A-2. Hazard Baseline Checklist for MCO Load Node. (11 sheets.)

\begin{tabular}{|c|c|c|c|c|}
\hline System & Cask/MCO Loadout & \multirow{2}{*}{\multicolumn{3}{|c|}{$\mathbf{M L}$}} \\
\hline Node & MCO Load (ML) & & & \\
\hline Type of Hazard & Eorm of Hazard & Y & N & Description \\
\hline \multirow{12}{*}{$\begin{array}{l}\text { J. } \\
\text { EXPLOSIVES/ } \\
\text { PYROPHORICS }\end{array}$} & 1. Caps & & $\checkmark$ & \\
\hline & 2. Primer cord & & $\checkmark$ & \\
\hline & 3. Dynamite & & $\checkmark$ & \\
\hline & 4. Scrub chemicals & & $\checkmark$ & \\
\hline & 5. Dusts & & $\checkmark$ & \\
\hline & 6. Hydrogen & & $\checkmark$ & \\
\hline & 7. Gases, other & & $\checkmark$ & \\
\hline & 8. Nitrates & & $\checkmark$ & \\
\hline & 9. Peroxides & & $\checkmark$ & \\
\hline & 10. Pu and $U$ metal & $\checkmark$ & & Covered by ML-G-3b and ML-R-1b \\
\hline & 11. Sodium & & $\checkmark$ & \\
\hline & 12. Other & & $\checkmark$ & \\
\hline
\end{tabular}


Table 3A-2. Hazard Baseline Checklist for MCO Load Node. (11 sheets.)

\begin{tabular}{|c|c|c|c|c|}
\hline System & Cask/MCO Loadout & & & \\
\hline Node & MCO Load (ML) & & & \\
\hline Type of Hazard? & . Form of Hazard & $Y$ & $\mathrm{~N}$ & Description \\
\hline $\mathrm{K}$ & 1. Vaults & & $\checkmark$ & \\
\hline $\begin{array}{l}\text { NUCLEAR } \\
\text { CRITICALITY }\end{array}$ & $\begin{array}{l}\text { 2. Temporary Storage } \\
\text { Areas }\end{array}$ & $\checkmark$ & & $\begin{array}{l}\text { Queue - FRS } \\
\text { Shuttle - MLS (MLS CSER) }\end{array}$ \\
\hline & $\begin{array}{l}\text { 3. Shipping and } \\
\text { receiving area }\end{array}$ & $\checkmark$ & & covered by MLS CSER \\
\hline & 4. Filters & & $\checkmark$ & \\
\hline & 5. Casks & $\checkmark$ & & covered by MCO CSER \\
\hline & 6. Burial ground & & $\checkmark$ & \\
\hline & 7. Storage racks & & $\checkmark$ & See ML-K-2 above \\
\hline & 8. Canals and basins & $\checkmark$ & & covered by FRS and MLS CSER \\
\hline & 9. Decon solution & & $\checkmark$ & \\
\hline & $\begin{array}{l}\text { 10. Trucks, forklifts, } \\
\text { dollies }\end{array}$ & & $\checkmark$ & \\
\hline & 11. Hand carry & & $\checkmark$ & \\
\hline & 12. Cranes/lifts & $\checkmark$ & & covered by MLS CSER \\
\hline & $\begin{array}{l}\text { 13. Hot cells, assembly, } \\
\text { inspection }\end{array}$ & & $\checkmark$ & \\
\hline & 14. Laboratories & & $\checkmark$ & \\
\hline & 15. Other & & $\checkmark$ & \\
\hline
\end{tabular}


Table 3A-2. Hazard Baseline Checklist for MCO Load Node. (11 sheets.)

\begin{tabular}{|c|c|c|c|c|}
\hline \multirow{2}{*}{ System } & \multirow{2}{*}{\begin{tabular}{|l} 
Cask/MCO Loadout \\
MCO Load (ML) \\
\end{tabular}} & \multirow{2}{*}{\multicolumn{3}{|c|}{$\mathbf{M L}$}} \\
\hline & & & & \\
\hline Type of Hazard & Form of Hazard & प1 & $\mathbf{N}$ & Description \\
\hline \multirow{16}{*}{$\begin{array}{l}\text { L. } \\
\text { FLAMMABLE } \\
\text { MATERIALS }\end{array}$} & 1. Packing materials & & $\checkmark$ & \\
\hline & 2. Rags & & $\checkmark$ & \\
\hline & 3. Gasoline & & $\checkmark$ & \\
\hline & 4. Lube oil & & $\checkmark$ & \\
\hline & 5. Coolant oil & & $\checkmark$ & \\
\hline & 6. Paint solvent & & $\checkmark$ & \\
\hline & 7. Diesel fuel & & $\checkmark$ & \\
\hline & 8. Buildings \& contents & & $\checkmark$ & \\
\hline & 9. Trailers and contents & & $\checkmark$ & \\
\hline & 10. Grease & & $\checkmark$ & \\
\hline & 11. Hydrogen & & $\checkmark$ & \\
\hline & 12. Nitric acid & & $\checkmark$ & . \\
\hline & 13. Organics & & $\checkmark$ & \\
\hline & 14. Gases - others & & $\checkmark$ & \\
\hline & 15. Liquids - others & & $\checkmark$ & \\
\hline & 16. Other & & $\checkmark$ & \\
\hline
\end{tabular}


Table 3A-2. Hazard Baseline Checklist for MCO Load Node. (11 sheets.)

\begin{tabular}{|c|c|c|c|c|}
\hline \multirow{3}{*}{\begin{tabular}{|l|} 
System \\
Node \\
Type of Hazard \\
\end{tabular}} & \multirow{3}{*}{\begin{tabular}{|l} 
Cask/MCO Loadout \\
MCO Load (ML) \\
Form of Hazard \\
\end{tabular}} & \multirow{2}{*}{\multicolumn{3}{|c|}{$\mathbf{M L}$}} \\
\hline & & & & \\
\hline & & \multirow[t]{2}{*}{$y$} & $\mathbf{N}$ & Description \\
\hline \multirow{9}{*}{$\begin{array}{l}\text { M. } \\
\text { HAZARDOUS } \\
\text { MATERIALS }\end{array}$} & 1. Alkali metals & & $\checkmark$ & \\
\hline & 2. Asphyxiants & & $\checkmark$ & \\
\hline & 3. Biologicals & 1 & & Spiders - SIH \\
\hline & 4. Carcinogens & & $\checkmark$ & \\
\hline & 5. Corrosives & & $\checkmark$ & \\
\hline & 6. Oxidizers & & $\checkmark$ & \\
\hline & 7. Toxics & & $\checkmark$ & \\
\hline & 8. Heavy metals & & $r$ & \\
\hline & 9. Other & & $\checkmark$ & \\
\hline \multirow{5}{*}{$\begin{array}{l}\text { N. } \\
\text { IONIZING } \\
\text { RADIATION } \\
\text { SOURCES }\end{array}$} & 1. Fissile material & $r$ & & $\begin{array}{l}\text { MLS CSER and various ALARA studies for } \\
\text { design and installation }\end{array}$ \\
\hline & $\begin{array}{l}\text { 2. Radiography } \\
\text { equipment }\end{array}$ & & $\checkmark$ & \\
\hline & 3. Radioactive material & $\checkmark$ & & $\begin{array}{l}\text { a. Fuel is at new reference height in queue/shuttle } \\
\text { and will allow less response time in the event of } \\
\text { basin drainage (ML-R-1a). } \\
\text { b. Reference ML-G-3a } \\
\text { c. Reference ML-G-3b }\end{array}$ \\
\hline & 4. Radioactive sources & $\checkmark$ & & Radiation survey instruments; SIH \\
\hline & 5. Other - $\mathrm{Kr} 85$ & & $\checkmark$ & FRS issue \\
\hline \multirow{3}{*}{$\begin{array}{l}\text { P. } \\
\text { EXTERNAL } \\
\text { EVENTS }\end{array}$} & 1. Explosion & $\checkmark$ & & Same as CI-P-1 SIH \\
\hline & 2. Fire & $\checkmark$ & & Same as $\mathrm{CI}-\mathrm{P}-2 \mathrm{SIH}$ \\
\hline & 3. Other sites & & $\checkmark$ & \\
\hline
\end{tabular}


Table 3A-2. Hazard Baseline Checklist for MCO Load Node. (11 sheets.)

\begin{tabular}{|c|c|c|c|c|}
\hline System & Cask/MCO Loadout & \multirow{2}{*}{\multicolumn{3}{|c|}{$\mathbf{M L}$}} \\
\hline Node & MCO Load (ML) & & & \\
\hline Type of Hazard & rorm of Hazard & $Y$ & $\mathrm{~N}$ & Description \\
\hline \multirow{5}{*}{$\begin{array}{l}\text { Q. } \\
\text { VEHICLES IN } \\
\text { MOTION (external } \\
\text { to facility) }\end{array}$} & 1. Airline & $\checkmark$ & & Covered by SAR \\
\hline & 2. Helicopter & $\checkmark$ & & Covered by SAR \\
\hline & 3. Train & $\checkmark$ & & Covered by SAR \\
\hline & 4. Truck/bus /car & $r$ & & Covered by SAR \\
\hline & 5. Other - Fork lifts & $\checkmark$ & & Covered by siting criteria \\
\hline \multirow[t]{10}{*}{$\begin{array}{l}\text { R. } \\
\text { NATURAL } \\
\text { PHENOMENA }\end{array}$} & 1. Earthquake & $\checkmark$ & & $\begin{array}{l}\text { a. Basin develops cracking and begins to drain } \\
\text { resulting in less response time due to increased } \\
\text { dose or the uncovering of fuel at the new } \\
\text { reference height (ML-N-3) } \\
\text { b. Earthquake causes general service gantry to fail } \\
\text { with basket held in highest position and basket } \\
\text { is uncovered as a result in basin drainage } \\
\text { (ML-G-3d) } \\
\text { c. Earthquake causes gantry to fail while loading } \\
\text { MCO basket; basket is removed from water }\end{array}$ \\
\hline & 2. Flood & & $\checkmark$ & N/A - Above flood level \\
\hline & 3. Lightning & $\checkmark$ & & $\begin{array}{l}\text { Lightning strike resulting in electrical power failure } \\
\text { (ML-A-16, ML-G-3d) }\end{array}$ \\
\hline & 4. Rain & & $\checkmark$ & \\
\hline & $\begin{array}{l}\text { 5. Snow, freezing } \\
\text { weather }\end{array}$ & & $\checkmark$ & \\
\hline & 6. Straight wind & & $r$ & \\
\hline & 7. Dust devil & & $\checkmark$ & \\
\hline & 8. Tomado & & $\checkmark$ & Grandfathered - non reactor facility \\
\hline & 9. Ashfall & & $\checkmark$ & \\
\hline & 10. Range fire & & $\checkmark$ & \\
\hline
\end{tabular}


Table 3A-3. Hazard Baseline Checklist for Cask Removal Node. (11 sheets)

\begin{tabular}{|c|c|c|c|c|}
\hline System & $\begin{array}{l}\text { Cask/MCO } \\
\text { Loadout }\end{array}$ & & & C \\
\hline Node & Cask Removal (CR) & & & \\
\hline Type of Hiazard & form of Hazard & $Y$ & $\mathrm{~N}$ & Description \\
\hline \multirow{16}{*}{$\begin{array}{l}\text { A. } \\
\text { ELECTRICAL }\end{array}$} & 1. Battery banks & & $\checkmark$ & \\
\hline & 2. Cable runs & $\checkmark$ & & $\mathrm{SIH}$ \\
\hline & 3. Diesel generators & & $\checkmark$ & \\
\hline & 4. Electrical equipment & $\checkmark$ & & SIH \\
\hline & 5. HVAC heaters & 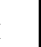 & $\checkmark$ & \\
\hline & 6. High voltage & $\checkmark$ & & SIH \\
\hline & 7. Motors & $\checkmark$ & & SIH \\
\hline & 8. Pumps & $\checkmark$ & & Air monitor equipment - SIH \\
\hline & 9, Power tools & $\checkmark$ & & SIH \\
\hline & 10. Switchgear & $\checkmark$ & & $\mathrm{SIH}$ \\
\hline & $\begin{array}{l}\text { 11. Service outlets, } \\
\text { fittings }\end{array}$ & $\checkmark$ & & SIH \\
\hline & 12. Transformers & $\checkmark$ & & Cask torquing tool - SIH \\
\hline & 13. Transmission lines & & $\checkmark$ & \\
\hline & 14. Underground wires & & $\checkmark$ & \\
\hline & 15. Wiring & 1 & & $\mathrm{SIH}$ \\
\hline & 16. Other & 8 & & $\begin{array}{l}\text { General power failure (event) (CR-G-3d/CI-R-1 } \\
\text { and 3) }\end{array}$ \\
\hline
\end{tabular}


Table 3A-3. Hazard Baseline Checklist for Cask Removal Node. (11 sheets)

\begin{tabular}{|c|c|c|c|c|}
\hline System & $\begin{array}{l}\text { Cask/MCO } \\
\text { Loadout }\end{array}$ & & & \\
\hline Node & Cask Removal (CR) & & & \\
\hline Type of hazard & Torm of Hazard & 1 & $\mathrm{~N}$ & Description \\
\hline \multirow{13}{*}{ THERMAL } & $\begin{array}{l}\text { 1. Bunsen burner/hot } \\
\text { plates }\end{array}$ & & $\checkmark$ & \\
\hline & 2. Electrical equipment & & $\checkmark$ & \\
\hline & $\begin{array}{l}\text { 3. Furnaces/ } \\
\text { boilers/ heater }\end{array}$ & & $\checkmark$ & \\
\hline & 4. Steam lines & & $\checkmark$ & \\
\hline & 5. Welding torch/arc & & $\checkmark$ & \\
\hline & $\begin{array}{l}\text { 6. Diesel units/fire } \\
\text { box/exhaust line }\end{array}$ & $\checkmark$ & & exhaust lines - SIH (also FHA) \\
\hline & $\begin{array}{l}\text { 7. Radioactive decay } \\
\text { heat }\end{array}$ & $\checkmark$ & & $\begin{array}{l}\text { a. Excessive decay heat pressurizes cask/MCO } \\
\text { once the MCO shield plug is installed and during } \\
\text { transit to the CVDF. (This has been evaluated and } \\
\text { is protected by requirement for } 24 \text { hour transport } \\
\text { window. Furthermore, the pressurization hazard is } \\
\text { more really initiated by hydrogen generation from } \\
\text { SNF corrosion.) } \\
\text { b. Prior to installing shield plug, fuel is under } \\
\text { water which provides adequate heat dissipation. } \\
\text { (After MCO is loaded and shield plug installed, } \\
\text { hazards coverage is provided by MCO Topical and } \\
\text { SARP and a transport window of time is required) }\end{array}$ \\
\hline & 8. Exposed components & & $\checkmark$ & \\
\hline & 9. Power tools & & $\checkmark$ & \\
\hline & 10. Convective & $\checkmark$ & & $\begin{array}{l}\text { Heat Transfer through cask annulus - basin water } \\
\text { provides heat sink. Coverage is provided by MCO } \\
\text { Topical and SARP after the MCO is loaded and the } \\
\text { shield plug is installed. }\end{array}$ \\
\hline & 11. Solar & & 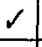 & \\
\hline & 12. Cryogenic & & $\checkmark$ & \\
\hline & 13. Other & & $\checkmark$ & \\
\hline
\end{tabular}


Table 3A-3. Hazard Baseline Checklist for Cask Removal Node. (11 sheets)

\begin{tabular}{|c|c|c|c|c|}
\hline System & $\begin{array}{l}\text { Cask/MCO } \\
\text { Loadout }\end{array}$ & & & CR \\
\hline Node & Cask Removal (CR) & & & \\
\hline Iype of litazard & form of Hazard & 1 & $\mathrm{~N}$ & Description \\
\hline C. & 1. Belts & $\checkmark$ & & SIH \\
\hline FRICTION & 2. Bearings & $\checkmark$ & & $\mathrm{SIH}$ \\
\hline & 3. Fans & & $\checkmark$ & \\
\hline & 4. Gears & $\checkmark$ & & $\mathrm{SIH}$ \\
\hline & 5. Motors & $\checkmark$ & & $\mathrm{SIH}$ \\
\hline & 6. Power tools & & $\checkmark$ & \\
\hline & 7. Other & & $\checkmark$ & \\
\hline thes & 1. Acids & & $\checkmark$ & \\
\hline CORROSIVES & 2. Caustics & & $\checkmark$ & \\
\hline & 3. Natural chemicals & & $\checkmark$ & \\
\hline & 4. Decon solution & $\checkmark$ & & SIH \\
\hline & $\begin{array}{l}\text { 5. High temperature } \\
\text { waste }\end{array}$ & & $\checkmark$ & \\
\hline & 6. Other & & $\checkmark$ & \\
\hline E. & 1. Centrifuges & & $\checkmark$ & \\
\hline KINETIC - & 2, Motors & $\checkmark$ & & $\mathrm{SIH}$ \\
\hline ROTATIONAL & 3. Pumps & & 8 & \\
\hline & 4. Cooling tower fans & & $\checkmark$ & . \\
\hline & 5. Laundry equipment & & $a$ & \\
\hline & 6. Shop equipment & $\checkmark$ & & $\begin{array}{l}\text { Air operated equipment: } \\
\text { - trailer landing gear - SIH } \\
\text { - cask and MCO torque tool - SIH }\end{array}$ \\
\hline & 7. Other & & 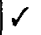 & \\
\hline
\end{tabular}


Table 3A-3. Hazard Baseline Checklist for Cask Removal Node. (11 sheets)

\begin{tabular}{|c|c|c|c|c|}
\hline System & $\begin{array}{l}\text { Cask/MCO } \\
\text { Loadout }\end{array}$ & & & \multirow[t]{2}{*}{$\mathbf{C R}$} \\
\hline Node & \multicolumn{3}{|l|}{ Cask Removal (CR) } & \\
\hline Type or liazard & Form of Hazard & $\mathbf{Y}$ & $\mathrm{N}$ & Description \\
\hline \multirow{7}{*}{$\begin{array}{l}\text { F. } \\
\text { KINETIC - } \\
\text { LINEAR }\end{array}$} & 1. Cars, trucks, buses & 6 & & trailer and truck (pulling out - SIH) \\
\hline & $\begin{array}{l}\text { 2. Forklifts, dollies, } \\
\text { carts }\end{array}$ & $r$ & & $\begin{array}{l}\text { - torque device cart - SIH } \\
\text { - hand carts - SIH }\end{array}$ \\
\hline & 3. Railroad & & $\checkmark$ & \\
\hline & 4. Obstructions & $\checkmark$ & & $\begin{array}{l}\text { walls, loadout pit curb, gantry structure, cask, } \\
\text { truck. Also lay down areas. (CR-F-5) }\end{array}$ \\
\hline & 5. Crane loads & $\checkmark$ & & $\begin{array}{l}\text { a. gantry is struck by cask while fully loaded } \\
\text { cask/MCO is being removed from the SLOP } \\
\text { b. transfer bay crane load strikes SLOP curb in a } \\
\text { linear direction while removing fully loaded } \\
\text { cask/MCO } \\
\text { c. transfer bay crane hook catches gantry during } \\
\text { operations }\end{array}$ \\
\hline & $\begin{array}{l}\text { 6. Pressure vessel } \\
\text { blowdown }\end{array}$ & & $\checkmark$ & \\
\hline & 7. Other & & $\checkmark$ & \\
\hline \multirow{5}{*}{$\begin{array}{l}\text { G. } \\
\text { MASS, GRAVITY, } \\
\text { HEIGHT }\end{array}$} & 1. Human effort & 1 & & Moving carts - SIH \\
\hline & 2. Stairs & $r$ & & $\mathrm{SIH}$ \\
\hline & 3. Lifts and cranes & $\alpha$ & & $\begin{array}{l}\text { a. transfer bay crane drops fully loaded } \\
\text { IP/cask/MCO from top IPSS position onto } \\
\text { IPSS bottom plate } \\
\text { b. transfer bay crane drops fully loaded } \\
\text { cask/MCO into immersion pail which is locked } \\
\text { in the upper position from a position just above } \\
\text { the SLOP curb } \\
\text { c. transfer bay craned drops fully loaded } \\
\text { cask/MCO directly onto SLOP curb } \\
\text { d. Transfer bay crane drops fully loaded } \\
\text { cask/MCO tip-and-hit on SLOP curb } \\
\text { e. transfer bay crane is affected by general power } \\
\text { failure event (CI-A-16) }\end{array}$ \\
\hline & 4. Bucket and ladder & & $\checkmark$ & \\
\hline & 5. Trucks & & $\checkmark$ & \\
\hline
\end{tabular}


Table 3A-3. Hazard Baseline Checklist for Cask Removal Node. (11 sheets)

\begin{tabular}{|c|c|c|c|c|}
\hline System & $\begin{array}{l}\text { Cask/MCO } \\
\text { Loadout }\end{array}$ & & & $\mathbf{C R}$ \\
\hline Node & Cask Removal (CR) & & & \\
\hline Type of hazard & Form of Hazard & $Y$ & $\mathrm{~N}$ & Description \\
\hline \multirow{9}{*}{$\begin{array}{l}\text { G. } \\
\text { MASS, GRAVITY, } \\
\text { HEIGHT } \\
\text { (cont.) }\end{array}$} & 6. Slings & $\checkmark$ & & $\begin{array}{l}\text { Slings used to raise IP/cask/MCO in SLOP. } \\
\text { Scenario bounded by CR-G-3b }\end{array}$ \\
\hline & 7. Hoists & $\checkmark$ & & SIH \\
\hline & 8. Elevators & & $\checkmark$ & \\
\hline & 9. Jacks & $\checkmark$ & & $\begin{array}{l}\text { trailer jacks fail while cask/MCO is in transfer bay } \\
\text { and takes out critical structural members }\end{array}$ \\
\hline & 10. Scaffold and ladders & $\checkmark$ & & $\mathrm{SIH}$ \\
\hline & 11. Pits and excavations & $\checkmark$ & & SIH \\
\hline & 12. Elevated doors & $\checkmark$ & & Roll-up doors - SIH \\
\hline & 13. Vessels & $\checkmark$ & & cask/MCO (CI-G-3) \\
\hline & 14. Other & $\checkmark$ & & Temporary shielding \\
\hline \multirow{12}{*}{$\begin{array}{l}\text { H. } \\
\text { PRESSURE - } \\
\text { VOLUME }\end{array}$} & 1. Boilers & & 6 & \\
\hline & 2. Surge tanks & & 1 & \\
\hline & 3. Autoclave & & 6 & \\
\hline & 4. Test loops & & $\checkmark$ & \\
\hline & 5. Gas bottles & $\checkmark$ & & $\begin{array}{l}\text { inert gas system - SIH } \\
\text { trailer brakes - SIH }\end{array}$ \\
\hline & 6. Pressure vessels & & $\checkmark$ & \\
\hline & 7. Stressed members & & $\checkmark$ & \\
\hline & 8. Gas receivers & $\checkmark$ & & Shop Air receiver - SIH \\
\hline & $\begin{array}{l}\text { 9. Negative pressure } \\
\text { collapse } \\
\end{array}$ & & 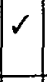 & \\
\hline & $\begin{array}{l}\text { 10. Steam headers and } \\
\text { lines }\end{array}$ & & $\checkmark$ & \\
\hline & 11. Other & $\checkmark$ & & immersion pail lid seal \\
\hline & 12. Confined Space & & $\checkmark$ & \\
\hline
\end{tabular}


Table 3A-3. Hazard Baseline Checklist for Cask Removal Node. (11 sheets)

\begin{tabular}{|c|c|c|c|c|}
\hline System & $\begin{array}{l}\text { Cask/MCO } \\
\text { Loadout }\end{array}$ & & & $\mathbf{C R}$ \\
\hline Node & Cask Removal (CR) & & & \\
\hline Trpe of Hazara & Form of Hazard & 1 & $\mathrm{~N}$ & Description \\
\hline \multirow{12}{*}{$\begin{array}{l}J . \\
\text { EXPLOSIVES/ } \\
\text { PYROPHORICS }\end{array}$} & 1. Caps & & $\sqrt{ }$ & \\
\hline & 2. Primer cord & & $\checkmark$ & \\
\hline & 3. Dynamite & & 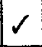 & \\
\hline & 4. Scrub chemicals & & $\checkmark$ & \\
\hline & 5. Dusts & & $\checkmark$ & \\
\hline & 6. Hydrogen & $\checkmark$ & & $\begin{array}{l}\text { Before MCO/Cask shield plug is installed it is } \\
\text { under water - safe. } \\
\text { After shield plug is installed, hydrogen generation } \\
\text { within cask/MCO has been analyzed by the MCO } \\
\text { Topical and the SARP. } \\
\text { (WHC-SD-SNF-OCD-001, SNF Project Product } \\
\text { Specification, Pajunen and Sederburg, require the } \\
\text { loaded MCO to be transported to CVDF in a } \\
\text { 24-hour time frame). }\end{array}$ \\
\hline & 7. Gases, other & & $r$ & \\
\hline & 8. Nitrates & & $r$ & \\
\hline & 9. Peroxides & & $\checkmark$ & \\
\hline & 10. $P u$ and $U$ metal & $\checkmark$ & & $\begin{array}{l}\text { A HAZOPS assumption was made that fuel does } \\
\text { not flash under water. This is an issue for the } \\
\text { entire SNF project and will be identified as an } \\
\text { enabling assumption to be reconciled prior to } \\
\text { operations. (HNF-2786, D. R. Duncan, } \\
\text { Assessment for Potential Rapid Oxidation of } \\
\text { Submerged N Reactor Fuel draft) }\end{array}$ \\
\hline & 11. Sodium & & $\checkmark$ & \\
\hline & 12. Other & & $\checkmark$ & \\
\hline
\end{tabular}


HNF-2456, Rev. 0

Table 3A-3. Hazard Baseline Checklist for Cask Removal Node. (11 sheets)

\begin{tabular}{|c|c|c|c|c|}
\hline System & $\begin{array}{l}\text { Cask/MCO } \\
\text { Loadout }\end{array}$ & & & $\mathbf{C R}$ \\
\hline Node & Cask Removal (CR) & & & \\
\hline Type of liazard & Form of Hazard & $y$ & $\mathrm{~N}$ & Description \\
\hline \multirow{15}{*}{$\begin{array}{l}\text { K. } \\
\text { NUCLEAR } \\
\text { CRITICALITY }\end{array}$} & 1. Vaults & & $\checkmark$ & \\
\hline & $\begin{array}{l}\text { 2. Temporary Storage } \\
\text { Areas }\end{array}$ & & $\checkmark$ & \\
\hline & $\begin{array}{l}\text { 3. Shipping and } \\
\text { receiving area }\end{array}$ & $\checkmark$ & & Immersion pail - covered by MLS CSER \\
\hline & 4. Filters & 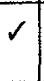 & & $\begin{array}{l}\text { pressure valve filter in MCO shield plug - not an } \\
\text { issue, covered by MCO CSER }\end{array}$ \\
\hline & 5. Casks & $\checkmark$ & & covered by MLS CSER \\
\hline & 6. Burial ground & & $\checkmark$ & \\
\hline & 7. Storage racks & & $\checkmark$ & \\
\hline & 8. Canals and basins & $\checkmark$ & & covered by MLS CSER \\
\hline & 9. Decon solution & & $\checkmark$ & \\
\hline & $\begin{array}{l}\text { 10. Trucks, forklifts, } \\
\text { dollies }\end{array}$ & & $\checkmark$ & \\
\hline & 11. Hand carry & & $\checkmark$ & \\
\hline & 12. Cranes/lifts & 8 & & covered by MLS CSER \\
\hline & $\begin{array}{l}\text { 13. Hot cells, assembly, } \\
\text { inspection }\end{array}$ & & $\checkmark$ & \\
\hline & 14. Laboratories & & $\checkmark$ & \\
\hline & 15. Other & & $\checkmark$ & \\
\hline
\end{tabular}


HNF-2456, Rev. 0

Table 3A-3. Hazard Baseline Checklist for Cask Removal Node. (11 sheets)

\begin{tabular}{|c|c|c|c|c|}
\hline System & $\begin{array}{l}\text { Cask/MCO } \\
\text { Loadout }\end{array}$ & & & CR \\
\hline Node & Cask Removal (CR) & & & \\
\hline Type of Hazard & I Form of Hazard & 8 & $\mathrm{~N}$ & Description \\
\hline \multirow{16}{*}{$\begin{array}{l}\text { L. } \\
\text { FLAMMABLE } \\
\text { MATERIALS } \\
\text { * Note - } \\
\text { (These are covered } \\
\text { by FHA) }\end{array}$} & 1. Packing materials & & $\checkmark$ & \\
\hline & 2. Rags & & $\checkmark$ & \\
\hline & 3. Gasoline & & $\checkmark$ & \\
\hline & 4. Lube oil & $\checkmark$ & & SIH (Truck) \\
\hline & 5. Coolant oil & $\checkmark$ & 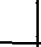 & SIH (Truck) \\
\hline & 6. Paint solvent & & $\checkmark$ & \\
\hline & 7. Diesel fuel & $\checkmark$ & & SIH (Truck) \\
\hline & 8. Buildings \& contents & $\checkmark$ & & \\
\hline & 9. Trailers and contents & 1 & & Grease, Tires - FHA \\
\hline & 10. Grease & $\checkmark$ & & Grease, Tires - FHA \\
\hline & 11. Hydrogen & $\checkmark$ & & Covered under CR-J- 6 \\
\hline & 12. Nitric acid & & $\checkmark$ & \\
\hline & 13. Organics & & $\checkmark$ & \\
\hline & 14. Gases - others & & $\checkmark$ & \\
\hline & 15. Liquids - others & & $\checkmark$ & \\
\hline & 16. Other & & $\checkmark$ & \\
\hline
\end{tabular}


Table 3A-3. Hazard Baseline Checklist for Cask Removal Node. (11 sheets)

\begin{tabular}{|c|c|c|c|c|}
\hline System & $\begin{array}{l}\text { Cask/MCO } \\
\text { Loadout }\end{array}$ & & & $\mathbf{C R}$ \\
\hline Node & Cask Removal (CR) & & & \\
\hline Iype of Hazard & form of Hazard & 1 & $\mathrm{~N}$ & $4+$ Description \\
\hline M. & 1. Alkali metals & & $\checkmark$ & \\
\hline HAZARDOUS & 2. Asphyxiants & $\checkmark$ & & Diesel Exhaust - SIH \\
\hline MATERIALS & 3. Biologicals & $\checkmark$ & & Spiders - SIH \\
\hline & 4. Carcinogens & $\checkmark$ & & Diesel Exhaust - SIH \\
\hline & 5. Corrosives & $\checkmark$ & & Battery Truck Acid - SIH \\
\hline & 6. Oxidizers & $d$ & & Decon agents - SIY \\
\hline & 7. Toxics & 1 & & Antifreeze - SIH \\
\hline & 8. Heavy metals & $\checkmark$ & & Temporary shielding - SIH \\
\hline & 9. Other & & $\checkmark$ & \\
\hline N. & 1. Fissile material & $\checkmark$ & & Covered by MLS CSER \\
\hline $\begin{array}{l}\text { IONIZING } \\
\text { RADIATION }\end{array}$ & $\begin{array}{l}\text { 2. Radiography } \\
\text { equipment }\end{array}$ & & $\checkmark$ & \\
\hline SOURCES & 3. Radioactive material & $\checkmark$ & & $\begin{array}{l}\text { - MCO Shield Plug Dose Rate Analysis, } \\
\text { HNF-SD-SNF-CN-026 } \\
\text { - potential splash during removal operations - SIH } \\
\text { - surface contramination - SIH } \\
\text { - Airborne contamination - SIH }\end{array}$ \\
\hline & 4. Radioactive sources & & $r$ & \\
\hline & 5. Neutron & $\checkmark$ & & $\begin{array}{l}\text { MCO Shield Plug Dose Rate Analysis, } \\
\text { HNF-SD-SNF-CN-026 }\end{array}$ \\
\hline P. & 1. Explosion & $\checkmark$ & & Trucks outside building - SIH \\
\hline EXTERNAL & 2. Fire & $\checkmark$ & & Trucks outside building - SIH \\
\hline EVENTS & 3. Other sites & & 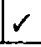 & \\
\hline
\end{tabular}


Table 3A-3. Hazard Baseline Checklist for Cask Removal Node. (11 sheets)

\begin{tabular}{|c|c|c|c|c|}
\hline System & $\begin{array}{l}\text { Cask/MCO } \\
\text { Loadout }\end{array}$ & & & $\mathbf{C R}$ \\
\hline Node & Cask Removal (CR) & & & \\
\hline Type of Irazard. & Form of Hazard & Y & $\mathrm{N}$ & Description \\
\hline \multirow{5}{*}{$\begin{array}{l}\text { Q. } \\
\text { VEHICLES IN } \\
\text { MOTION (external } \\
\text { to facility) }\end{array}$} & 1. Airplanes & $\checkmark$ & & Covered by SAR \\
\hline & 2. Helicopter & $\checkmark$ & & Covered by SAR \\
\hline & 3. Train & $\checkmark$ & & Covered by SAR \\
\hline & 4. Truck/bus /car & $\checkmark$ & & Covered by SAR \\
\hline & 5. Other - Fork lifts & $\checkmark$ & & Covered by sitting criteria. \\
\hline \multirow[t]{10}{*}{$\begin{array}{l}\text { R. } \\
\text { NATURAL } \\
\text { PHENOMENA }\end{array}$} & 1. Earthquake & $\checkmark$ & & $\begin{array}{l}\text { a. Seismic forces exerted on the IPSS transmits } \\
\text { excessive force to the SLOP walls } \\
\text { b. Initiating event of a general power failure } \\
\text { (CR-A-16) } \\
\text { Note: No need to analyze locking ring on aux hoist; } \\
\text { cask drops bounds }\end{array}$ \\
\hline & 2. Flood & & $\checkmark$ & N/A-Above flood plain \\
\hline & 3. Lightning & $\checkmark$ & & $\begin{array}{l}\text { Initiating event of a general power failure } \\
\text { (CR-A-16) }\end{array}$ \\
\hline & 4. Rain & & $\checkmark$ & \\
\hline & $\begin{array}{l}\text { 5. Snow, freezing } \\
\text { weather }\end{array}$ & $\checkmark$ & & Melting of snow/ice buildup on truck/trailer - SIH \\
\hline & 6. Straight wind & $\checkmark$ & & $\begin{array}{l}\text { SIH (Windbreak to further precludes contamination } \\
\text { spread) }\end{array}$ \\
\hline & 7. Dust devil & & $\checkmark$ & \\
\hline & 8. Tornado & & $\checkmark$ & Grandfathered - non reactor facility \\
\hline & 9. Ashfall & & $\checkmark$ & \\
\hline & 10. Range fire & & $\checkmark$ & \\
\hline
\end{tabular}


HNF-2456, Rev. 0

Table 3A-4. Hazard Analysis Summary

\section{Legend:}

Each hazardous condition postulated was recorded in one or more lines on the form.

A. Column A, "Hazard/Location," records the type of hazard and operational activity being discussed.

B. Column B, "Event Number," identifies each postulated activity with a unique identifier. The terminology used for the activity unique identification is as follows:

- $\quad$ AA Identifies which process, cask installation (CI), MCO loading (ML), or cask removal (CR)

- B Identifies which category of hazard from the hazard checklist generated based on Section 3.3.1.1.1 (checklists are shown in Tables 3A-1 through 3A-3)

- $\quad$ CC Identifies which subcategory of hazard from Section 3.3.1.1.1 (also found in checklists in Tables 3A-1 through 3A-3).

An example of the first entry is CI-F-la. This stands for an accident scenario that is to be identified during cask installation (CI), and is of the category "kinetic-linear" (F), and of the subset "cars, truck, buses" (1). The final letter designation indicates that a series of similar accidents scenarios are considered.

C. Column C, "event category", categorizes the initiator into one of three types:

- Natural phenomena - lightning, earthquakes, high wind, ashfall, etc.

- External events - events caused by human sources outside the facilities of interest such as aircraft crash, vehicle crash, gas pipeline ruptures, hazards from other facilities

- Internal events - events caused within the facility by process upset, human error, etc.

Most events were internal events with the exception of earthquakes which were natural phenomena. No external events were identified.

D. Column D, "Postulated Event Description," captures the accident sequence and identifies the potential consequences associated with the postulated accident scenario.

E. Column E, "Significant Cases or Energy Sources," provides additional information relating to the accident sequence. This column provides information related to the selection of controls presented in the following columns.

F. Column F, "Receptor," identifies the individual affected by the postulated accident: 
HNF-2456, Rev. 0

- Offsite public

- Onsite worker

- Facility worker.

This column is used to identify the consequence assessment code (column $\mathrm{J}$ ), an integral value used to identify the hazard severity

G. Column G, "Credited Prevention," in the final phase of the hazards analysis, identifies features that reduce the potential accident frequency or prevent the accident.

I. Column $\mathrm{H}$, "Scenario Frequency," indicates the qualitative frequency code established for the event sequence. One code is placed in each column "Without Prevention" and "With Prevention". The frequency relates to the highest consequences of the event sequence. Frequency without prevention is determined by the initator frequency only. Frequency with prevention takes into account the effectiveness of the credited prevention features. When the final set of credited prevention features is determined, the "With Prevention" frequency will reflect only the effect of these features. Table 3-3 in Section 3.3.1.2 provides the frequency code definitions.

J. Column J, "Consequence," indicates the qualitative consequence code established for the event sequence. One code is placed in each column "Without Mitigation" and "With Mitigation". These codes are initially identifie by column F, "Receptor." Table 3-4 in Section 3.3.1.2 provides the consequence assessment code definitions.

K. Column K, "Hazard Severity Bin Number," is a function of scenario frequency, consequence code, and hazard consequence level and is derived from Figures 3-1through 3-3. One code is placed in each column "Without Prevention \& Mitigation" and "With Prevention \& Mitigation."

L. Column L, "Defense-In-Depth Engineered Features and Alternative Controls," documents those design features, operational controls, and key elements of institutional programs that control hazards affecting facility workers. These items are summarized in Section 3.3.2.3.2. 
HNF-2456, Rev. 0

This page intentionally left blank. 


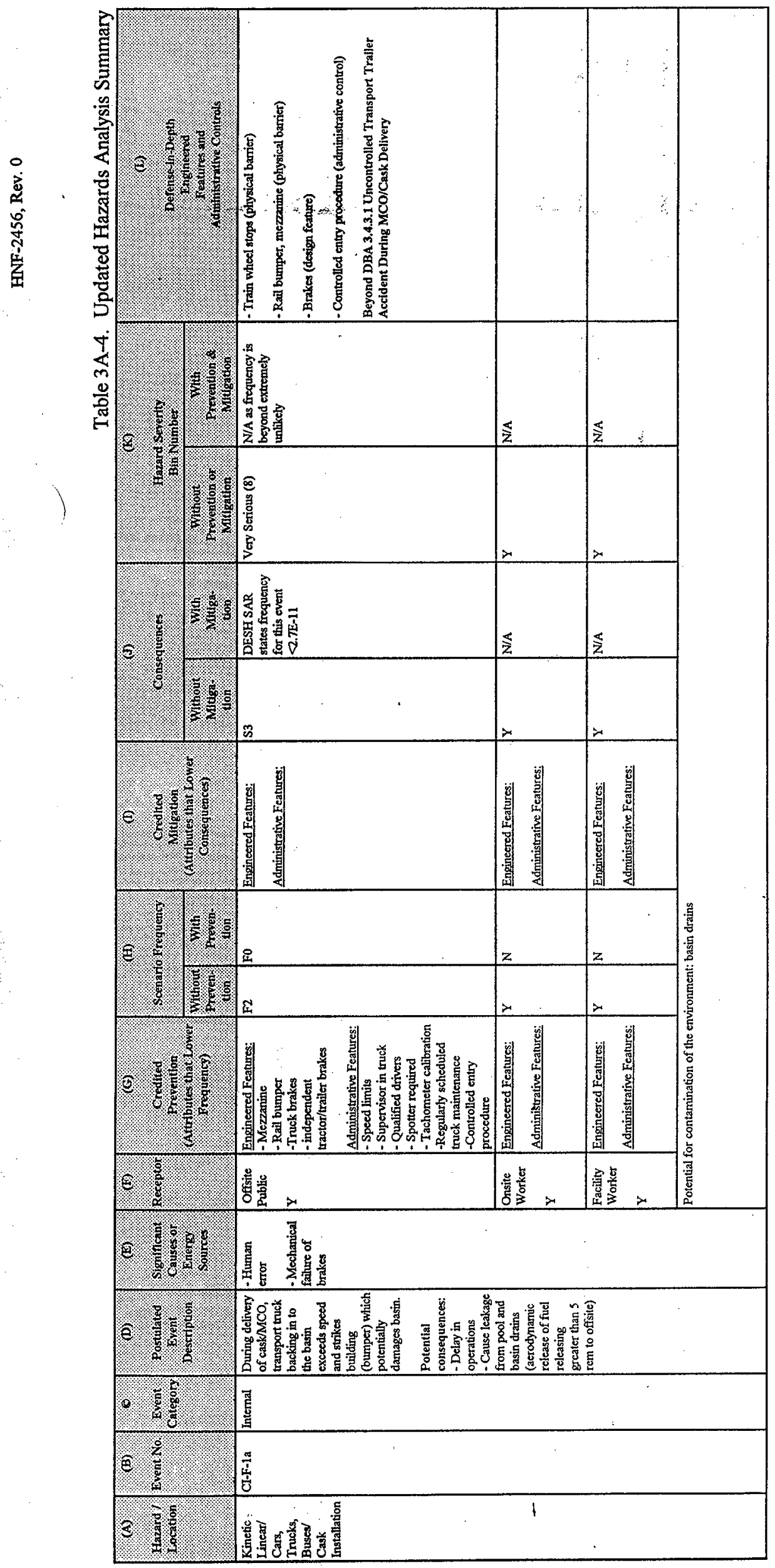

玄 


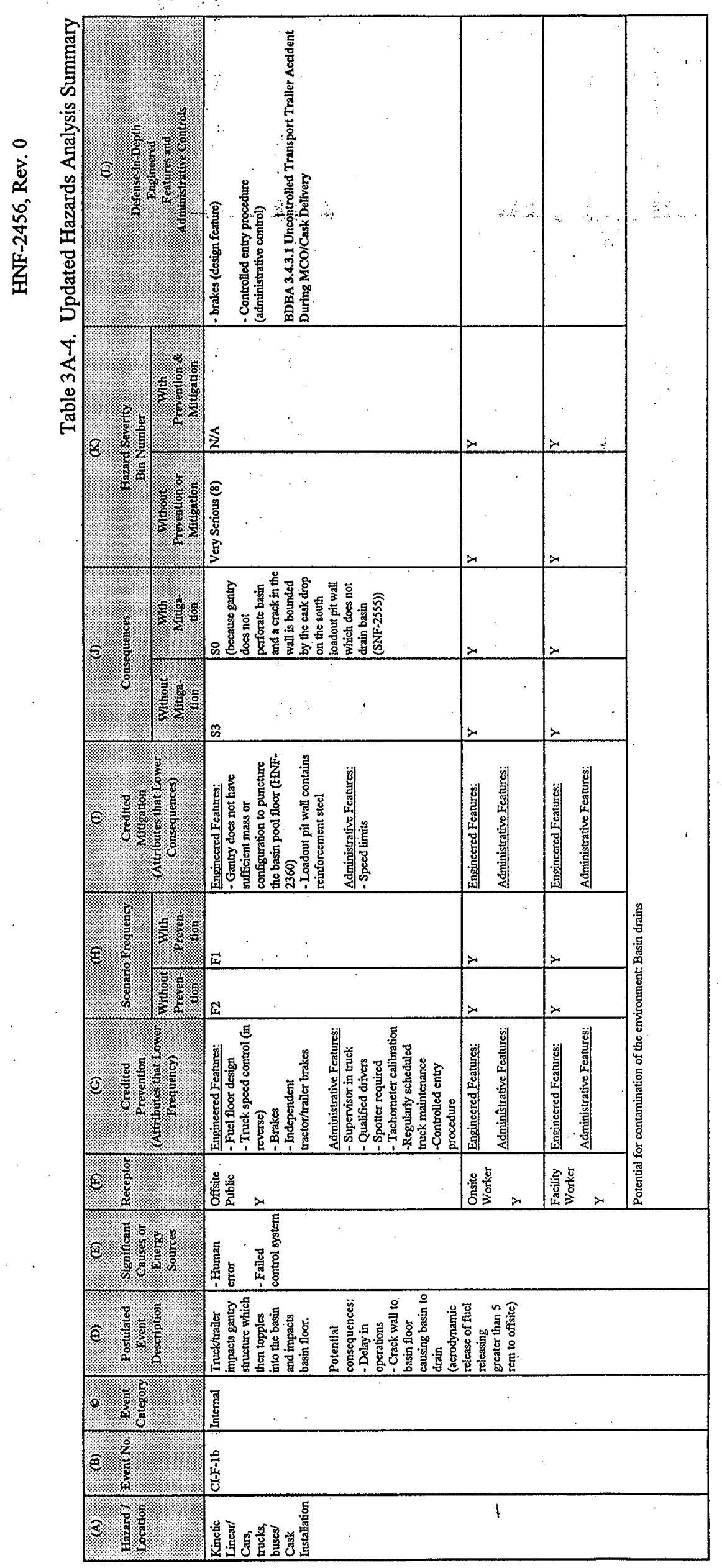


离

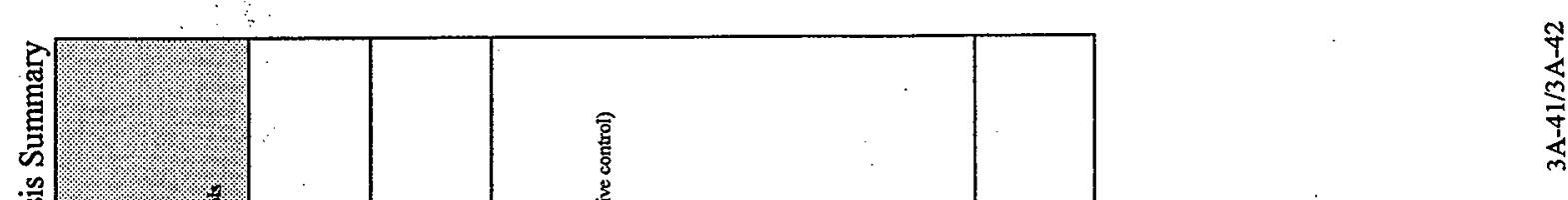

e. . . .

1.2.1.2.

|

.



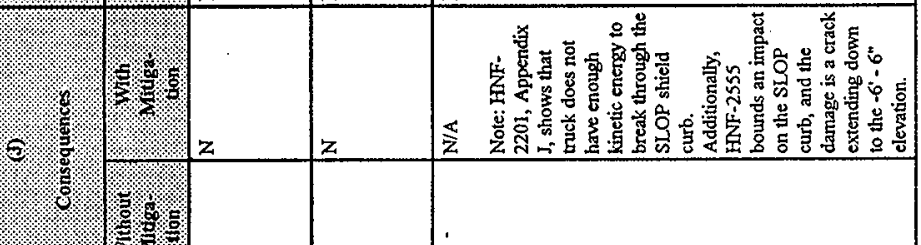

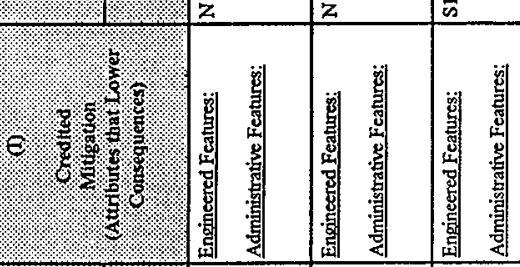

2.

(t) 5:

).:

<es $z$

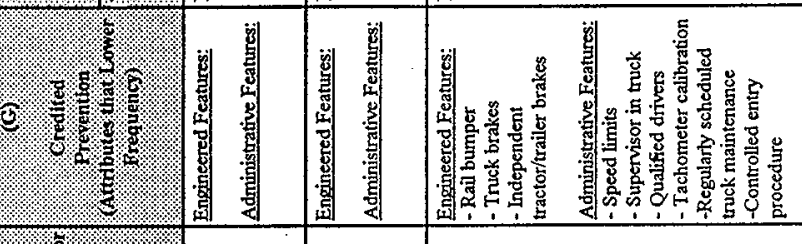

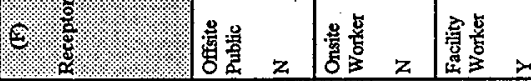

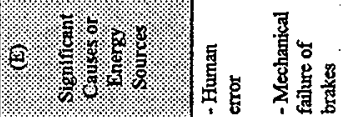

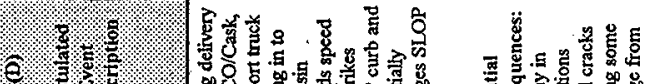

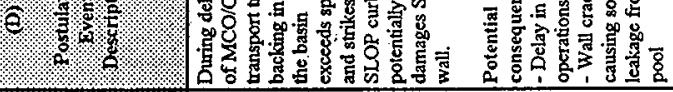

$\cdot \frac{18}{8}$

6. ?

3 䇺 


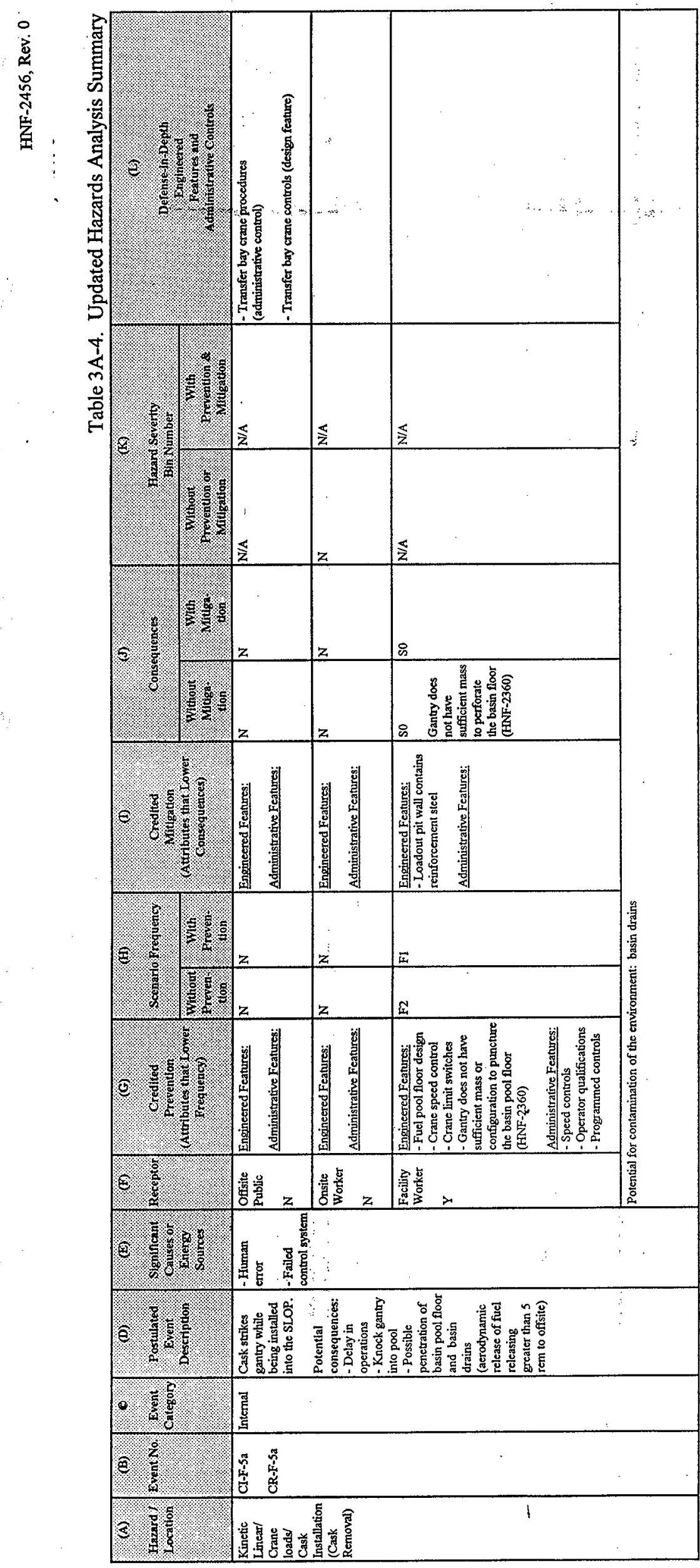


递

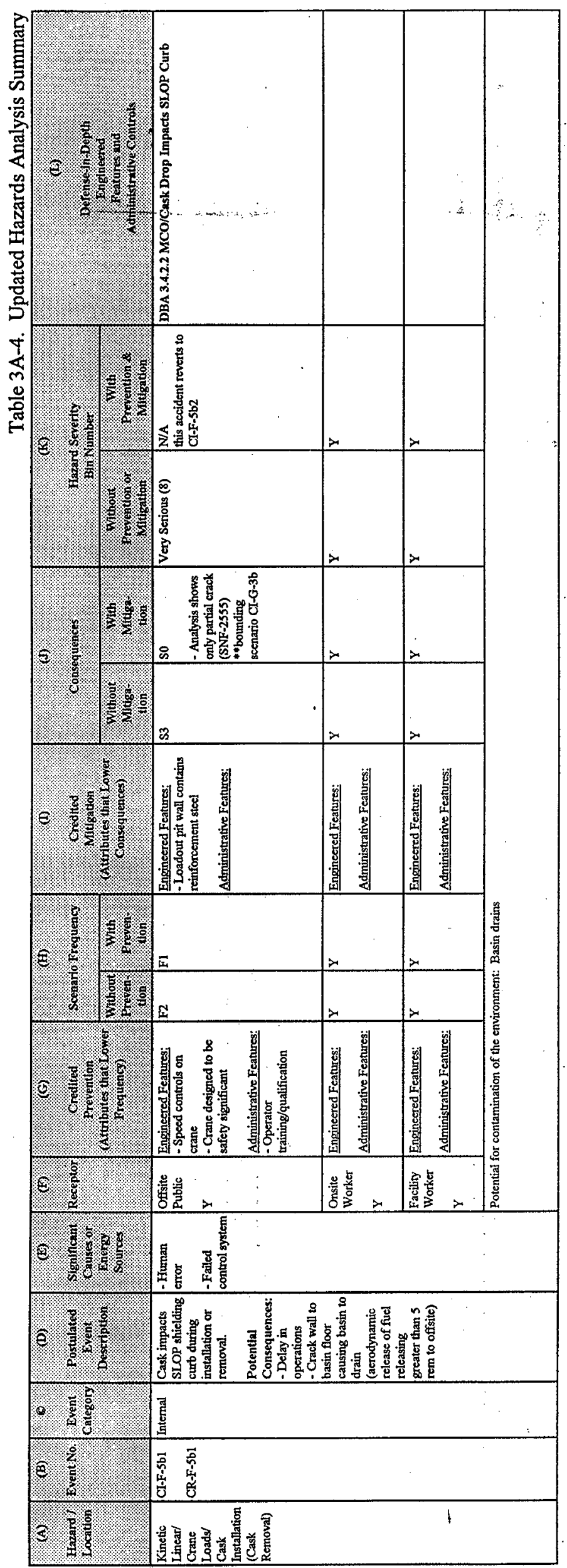




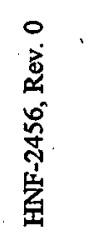
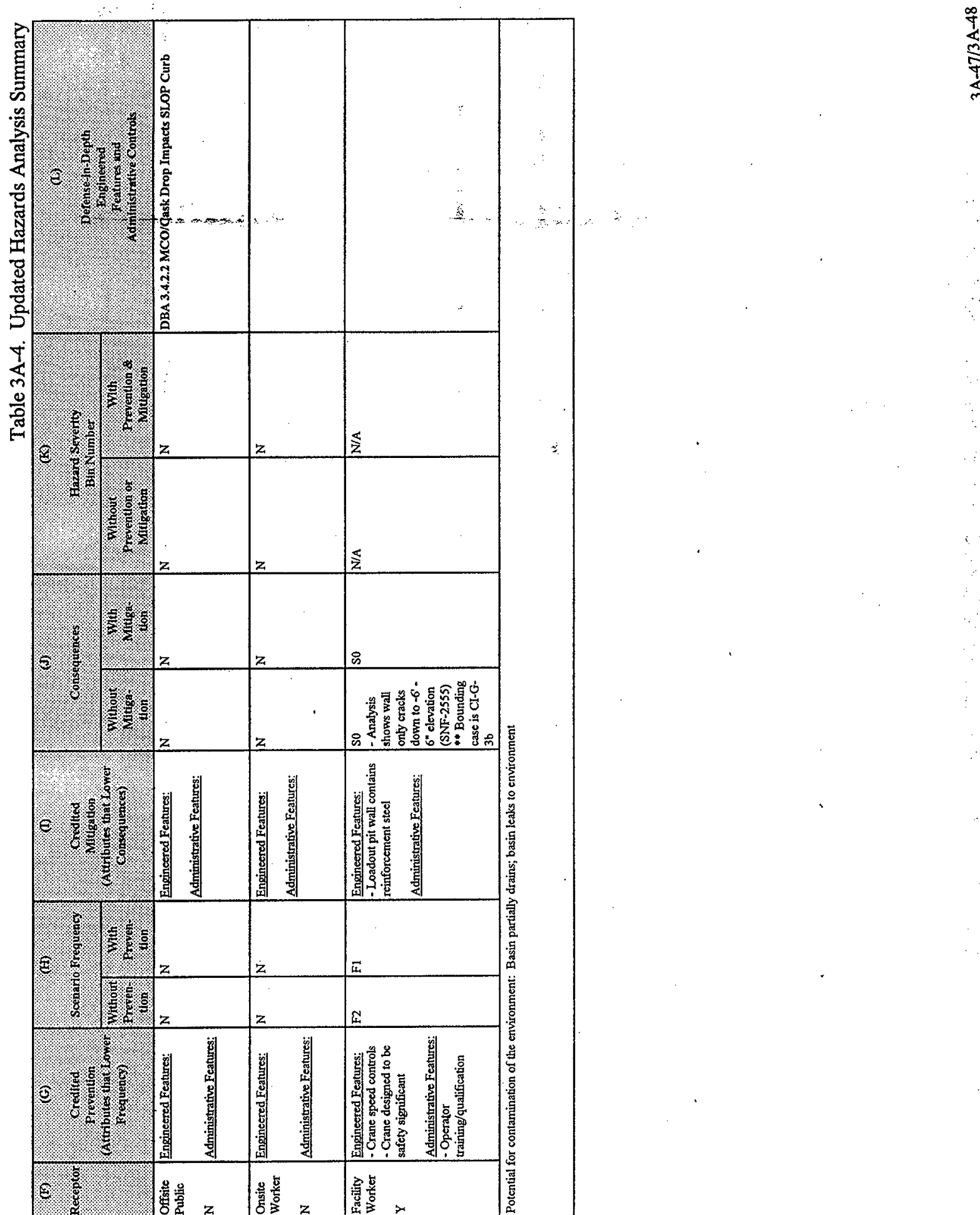

- Miln IIII

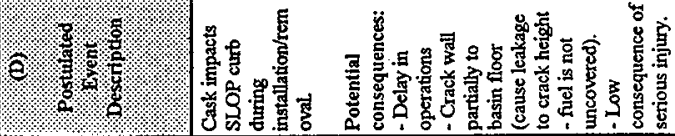

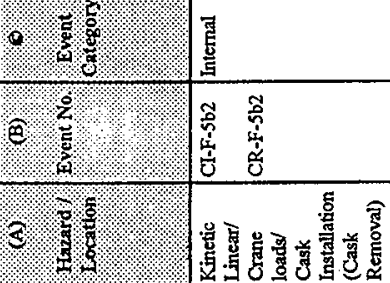




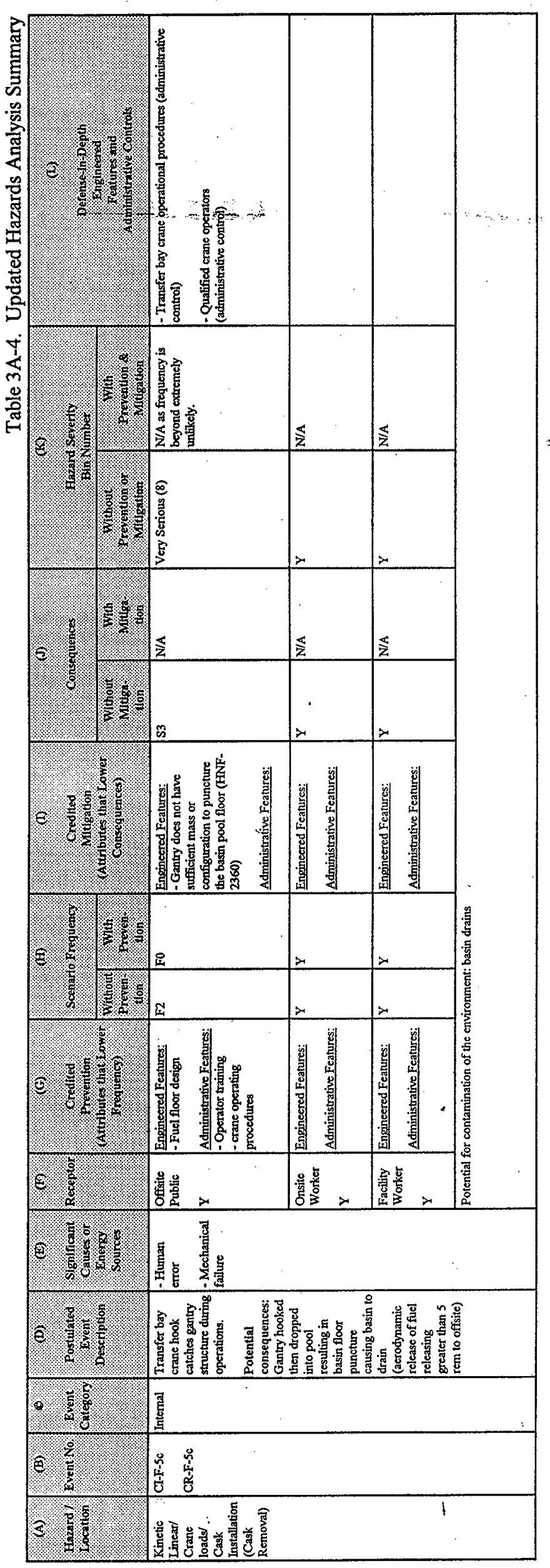




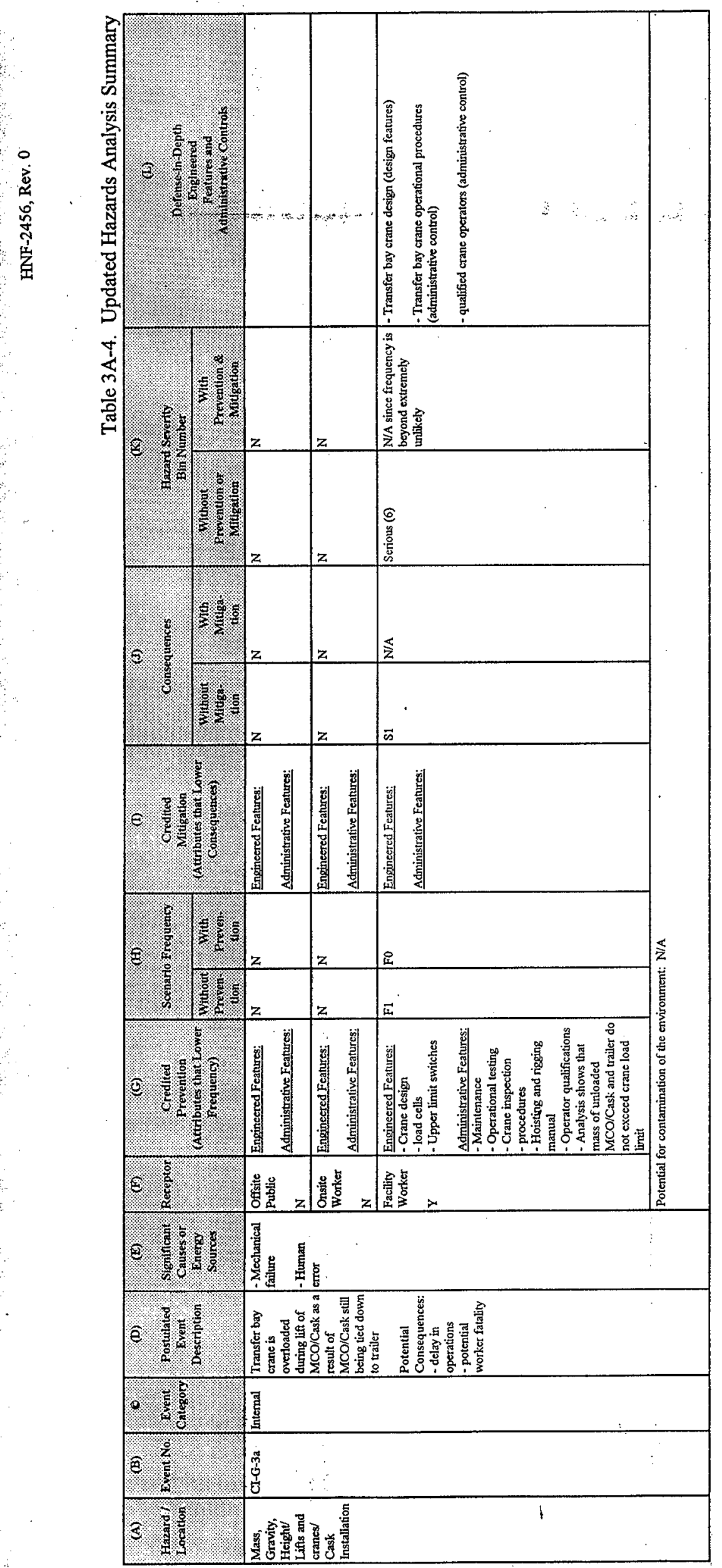




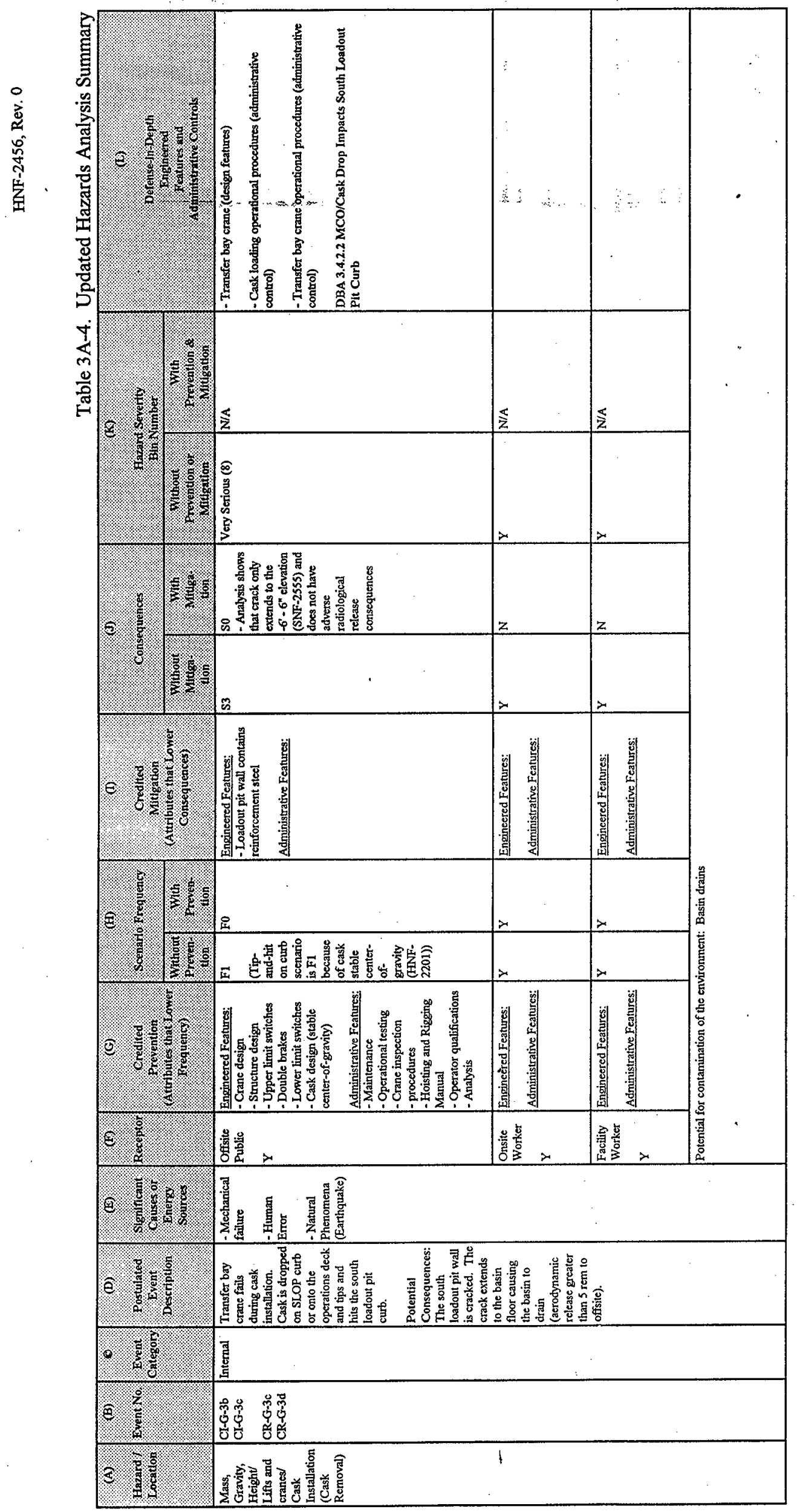




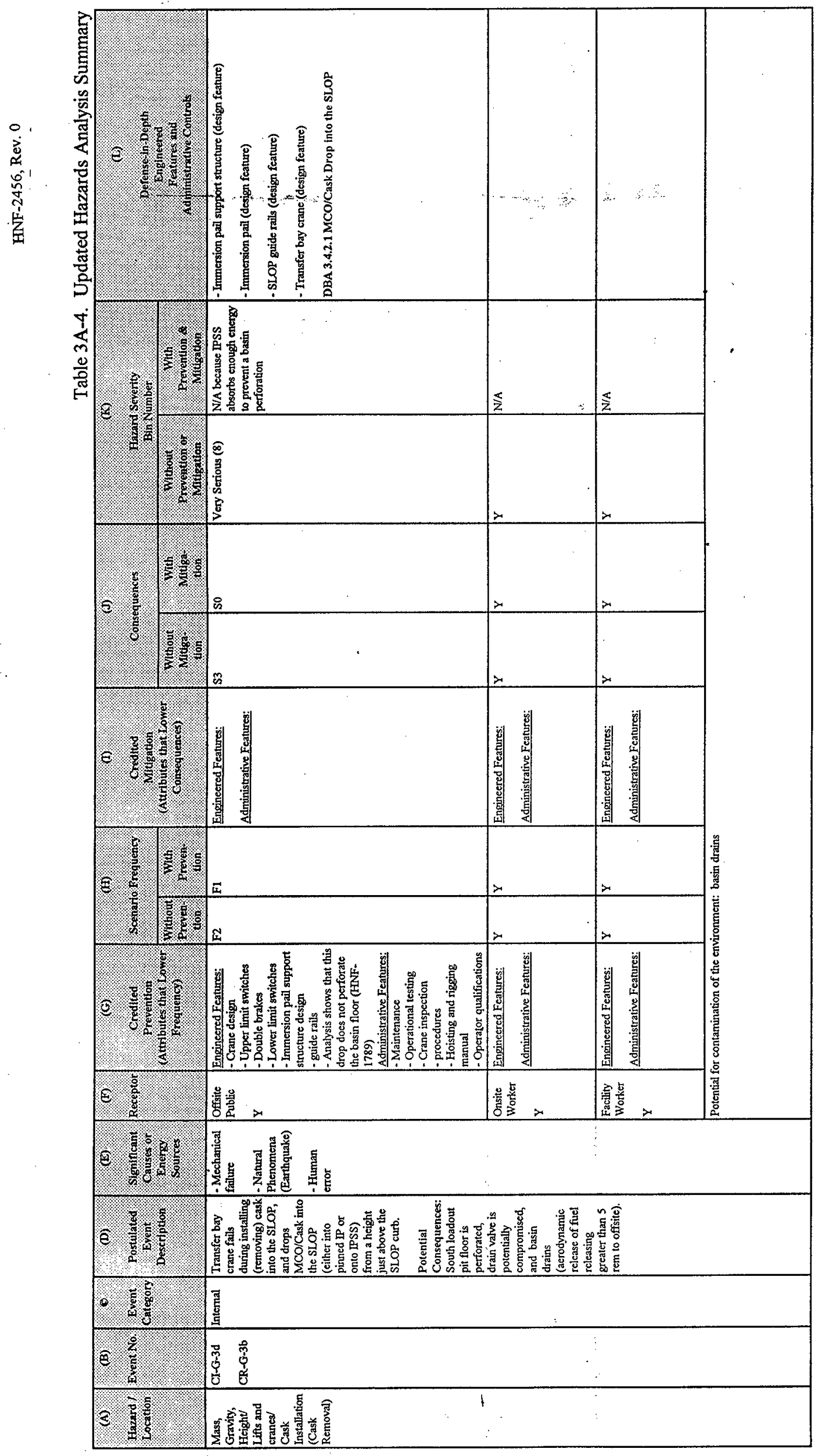

峁 


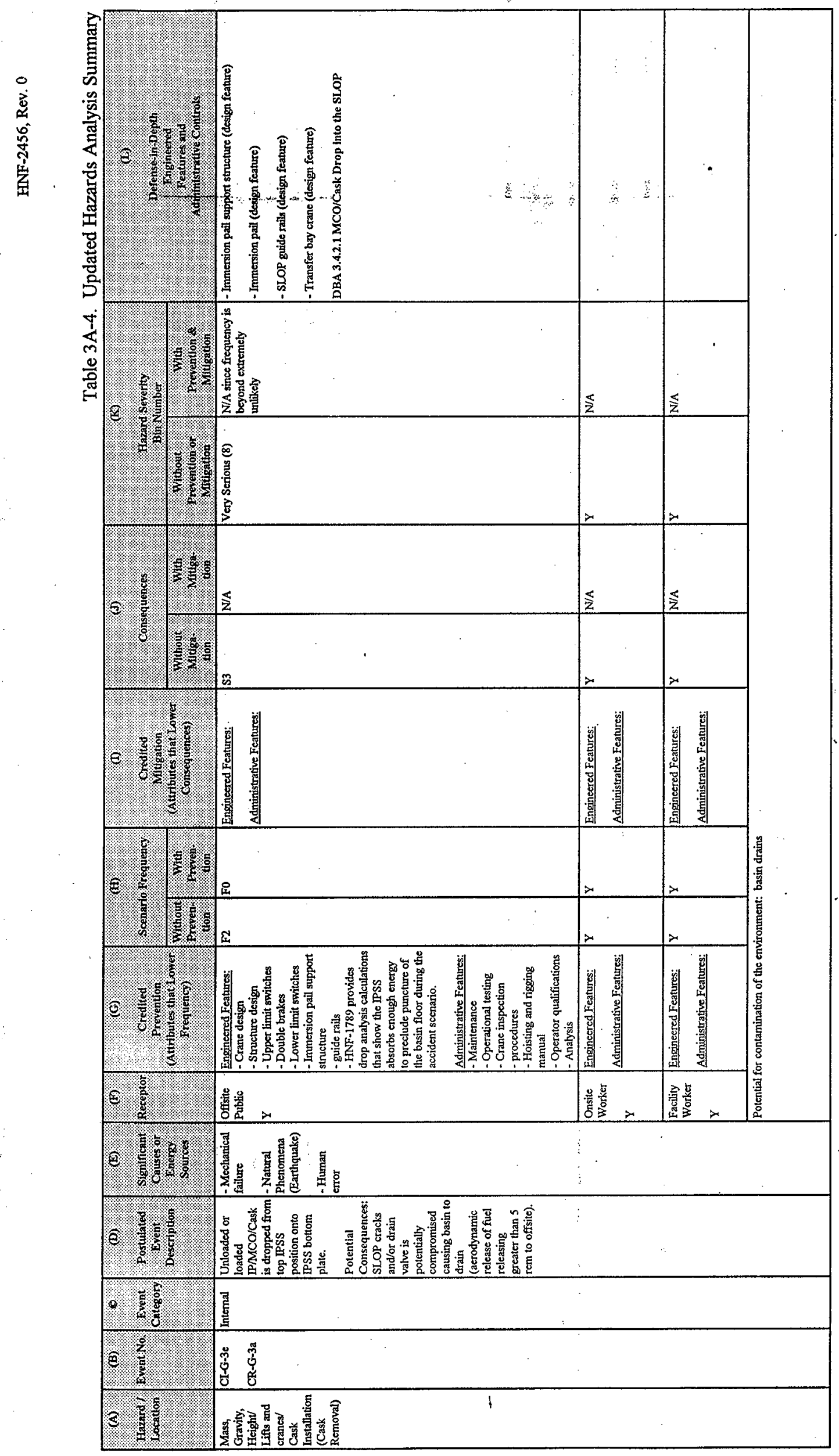

$\frac{\infty}{n}$ 


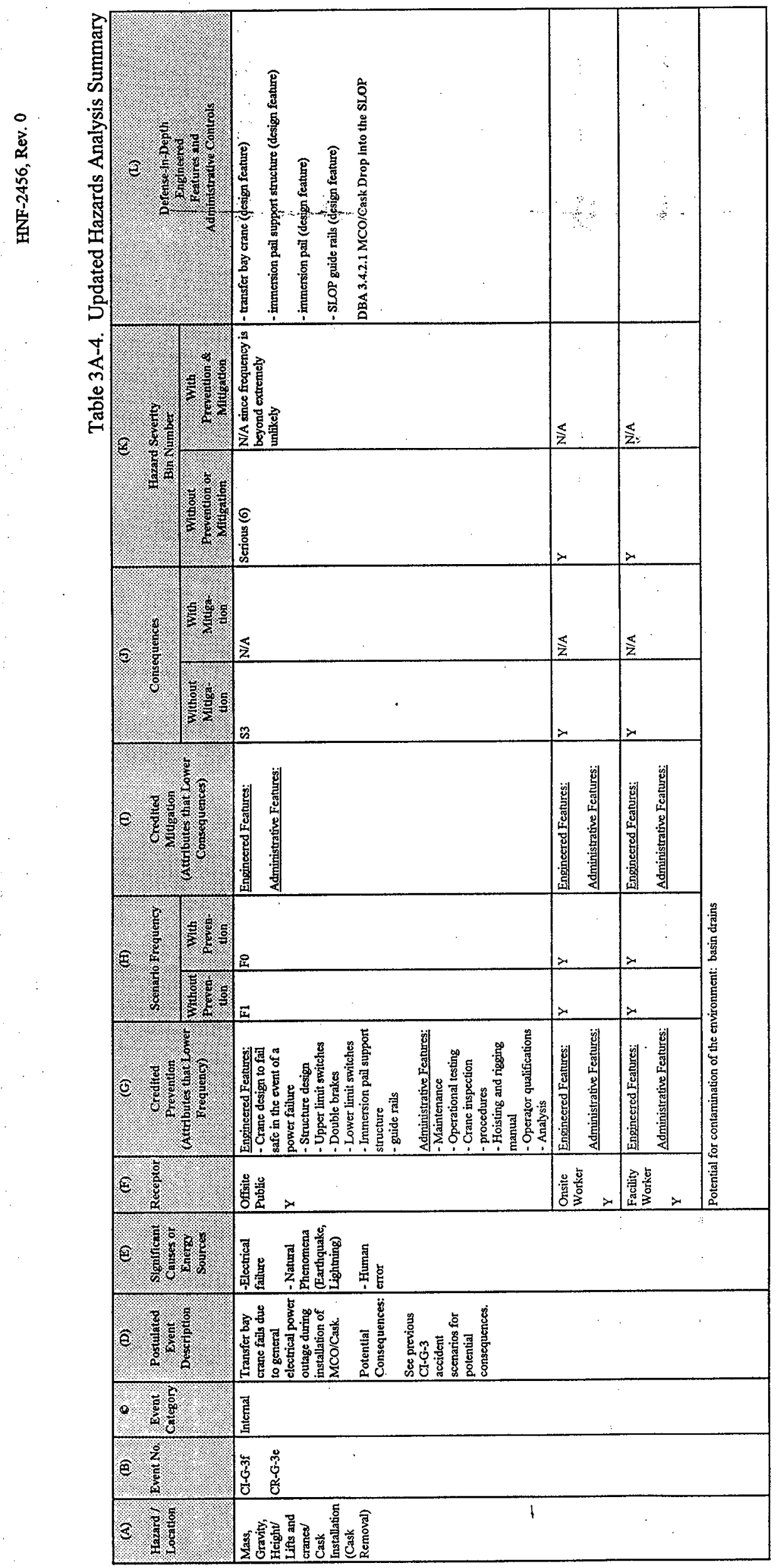

8
$\frac{1}{4}$
$\frac{1}{2}$
$\frac{1}{4}$ 


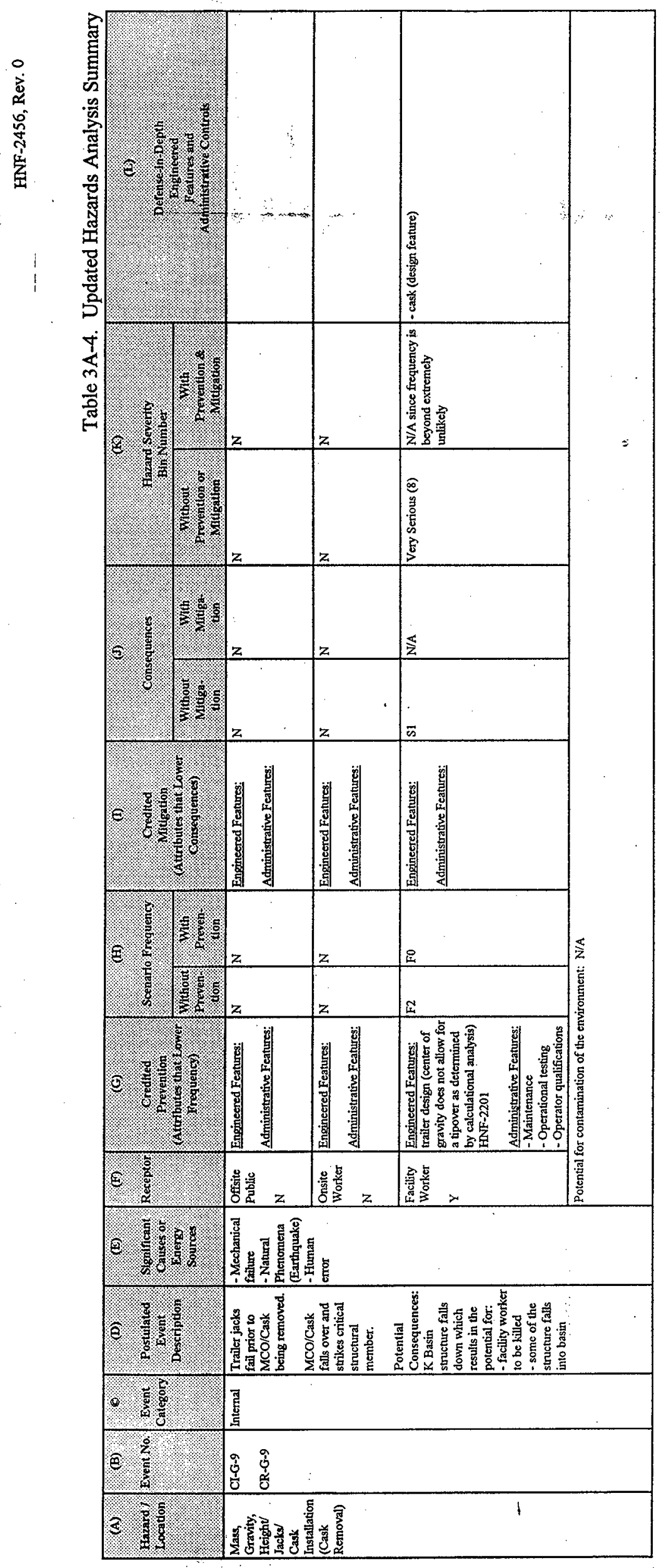

总 


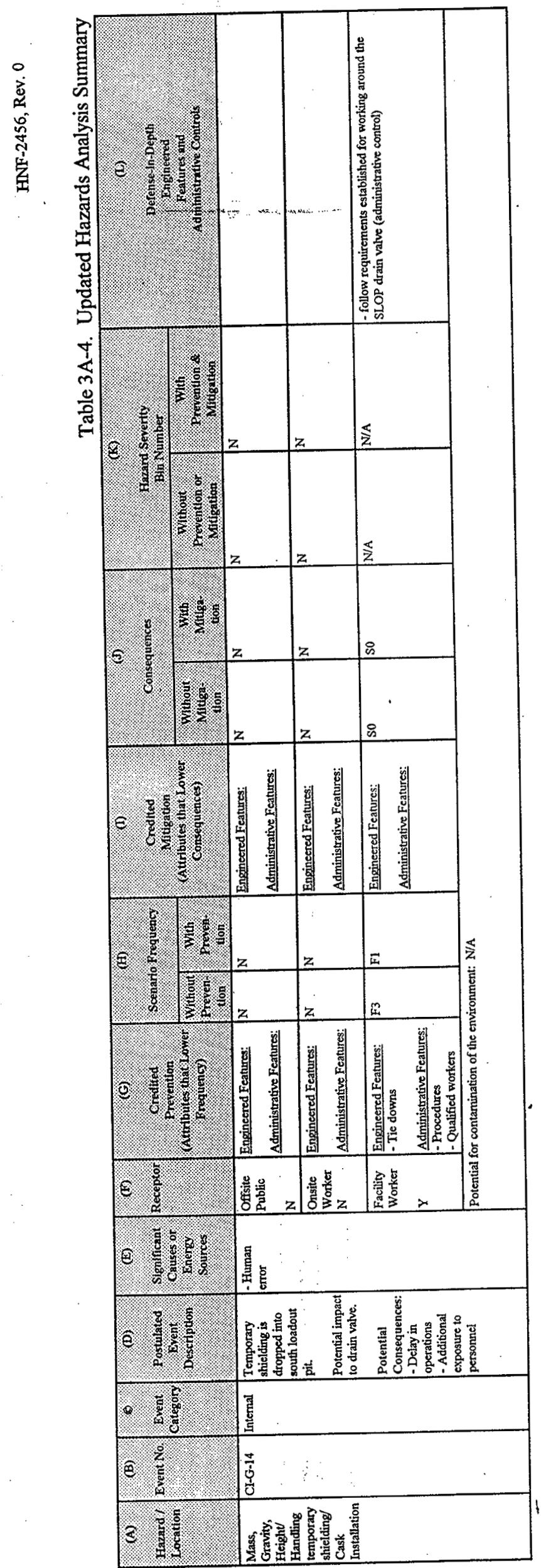




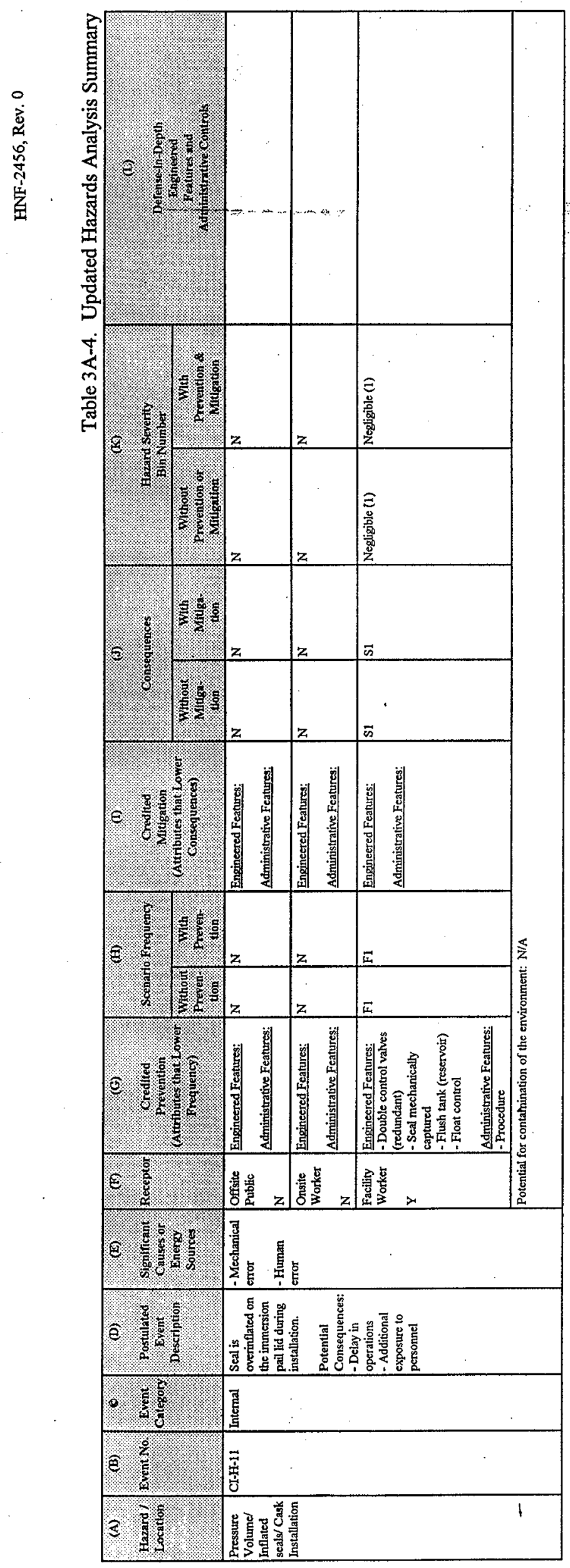

总 


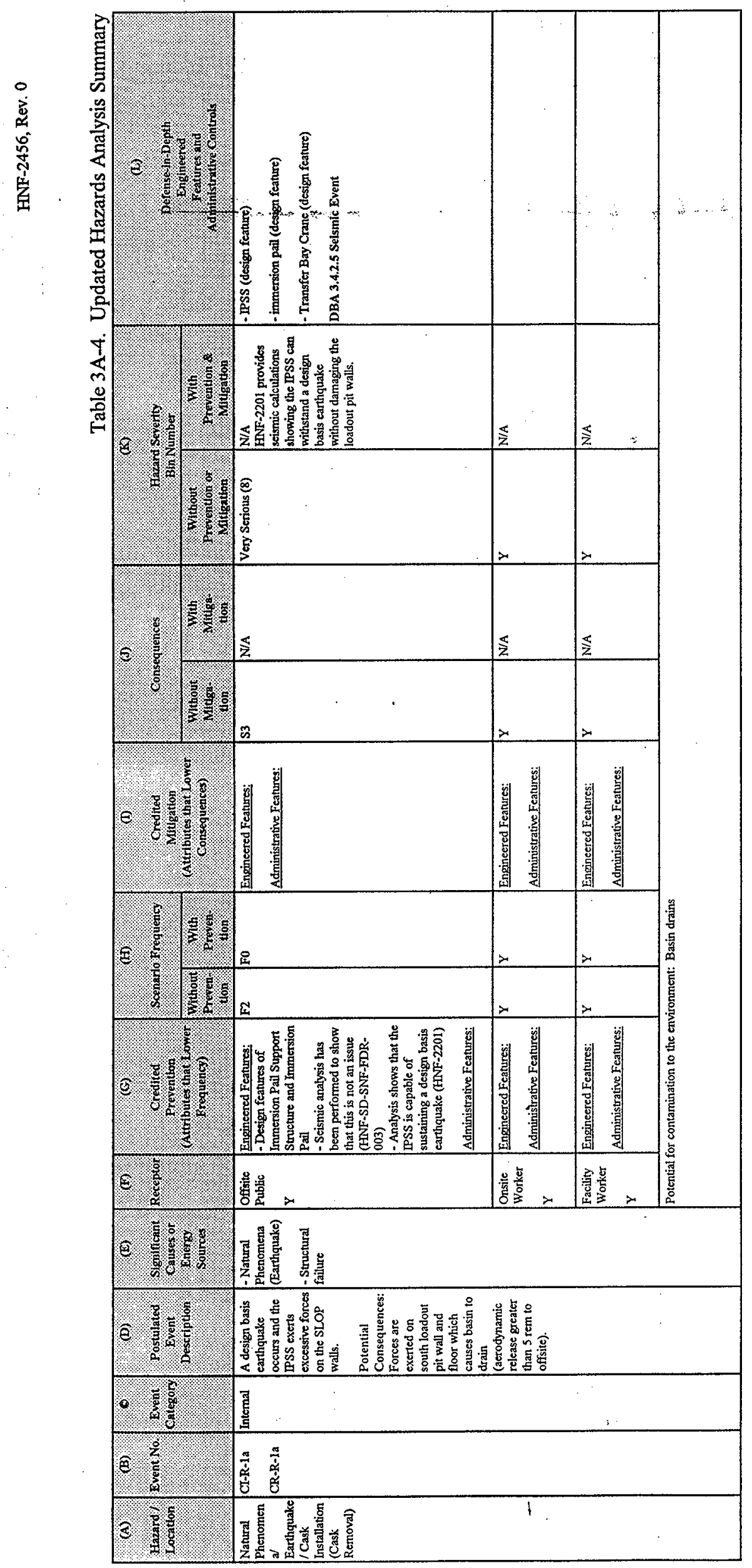

$\infty$
0
$\dot{1}$
$\frac{1}{5}$
$\substack{0 \\ \dot{m}}$ 


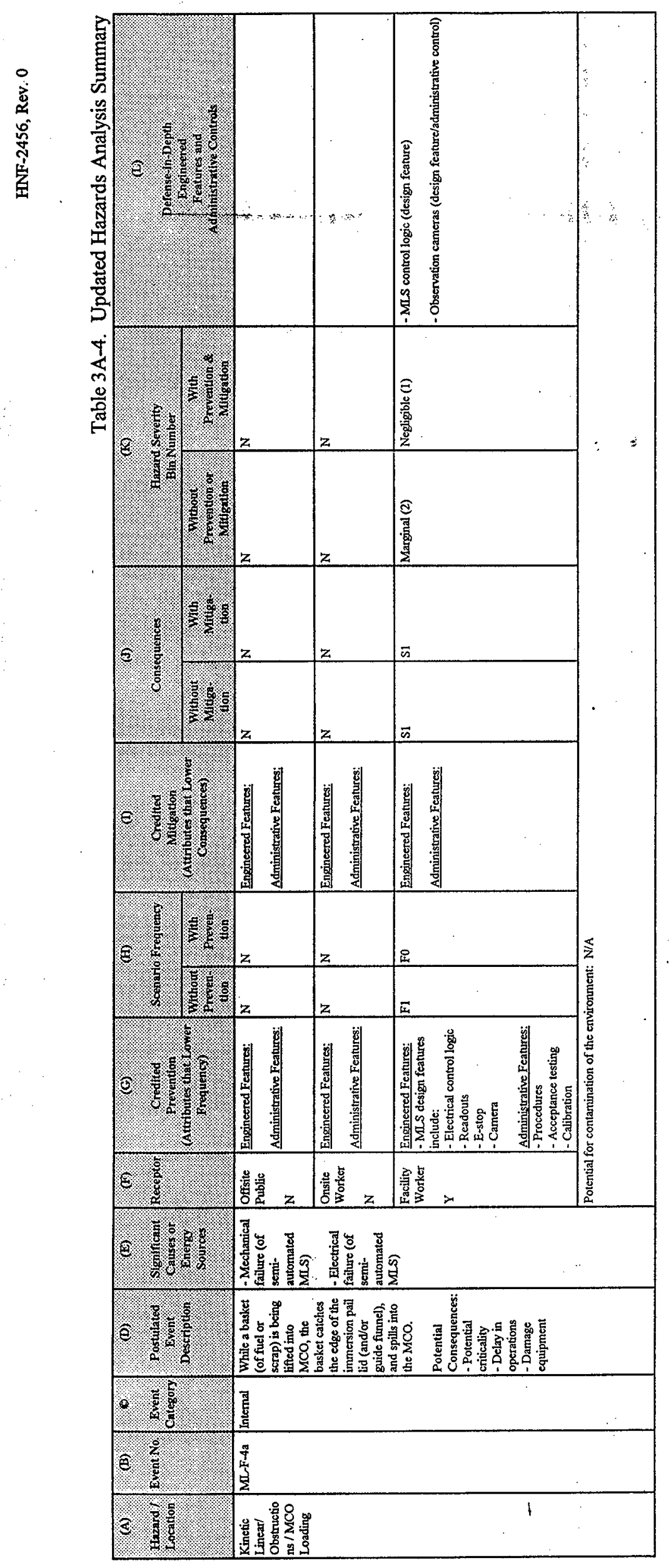

竞 


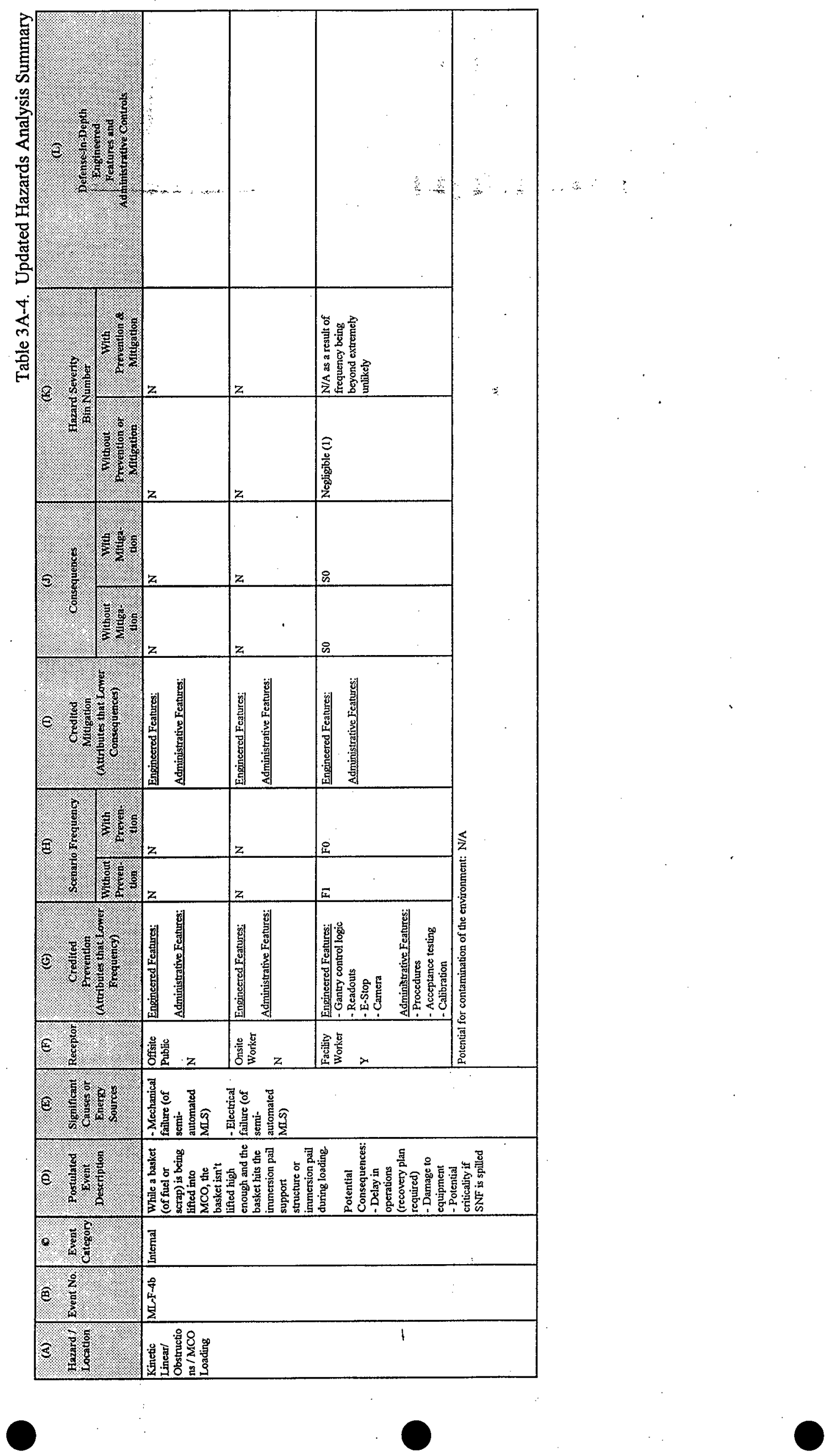




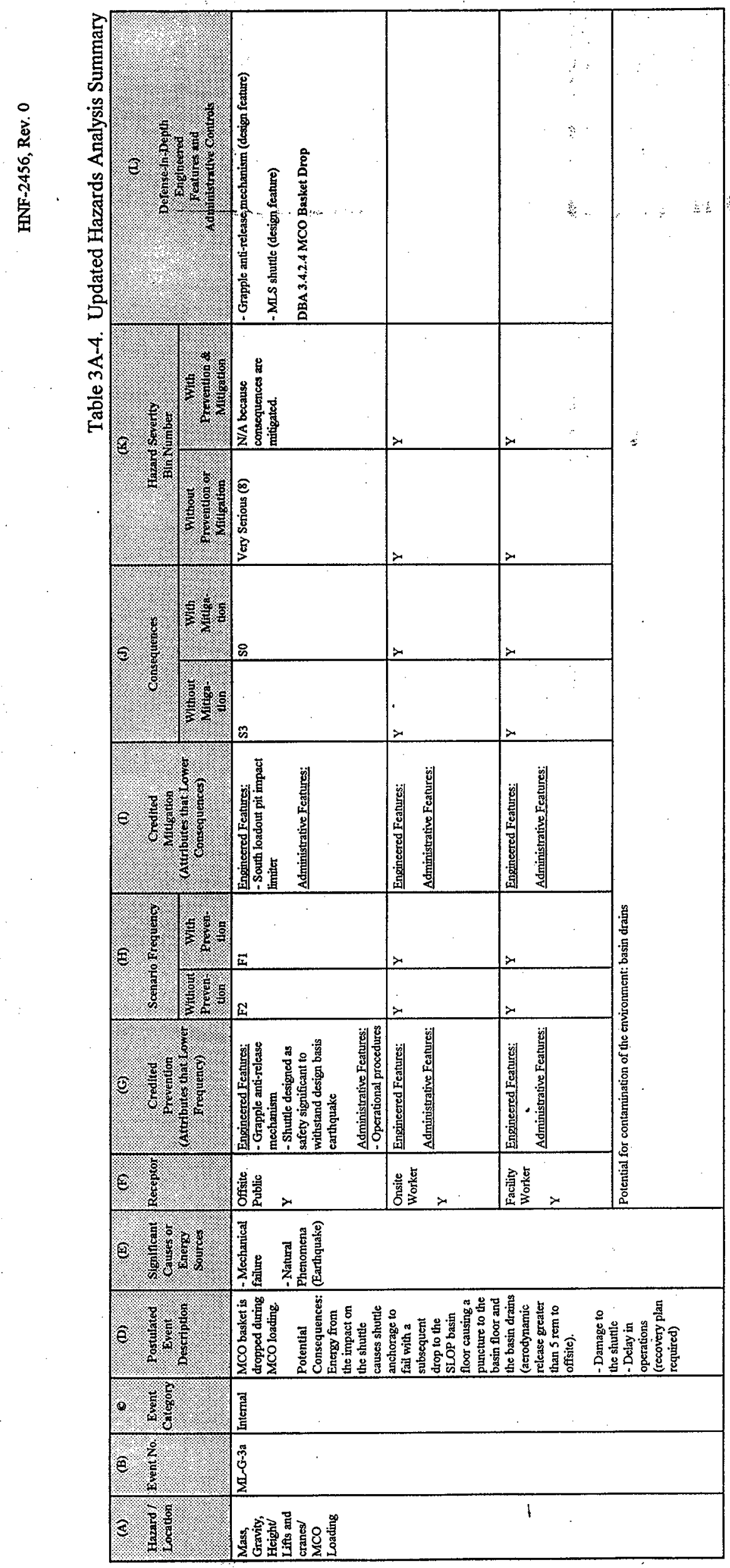

荒 


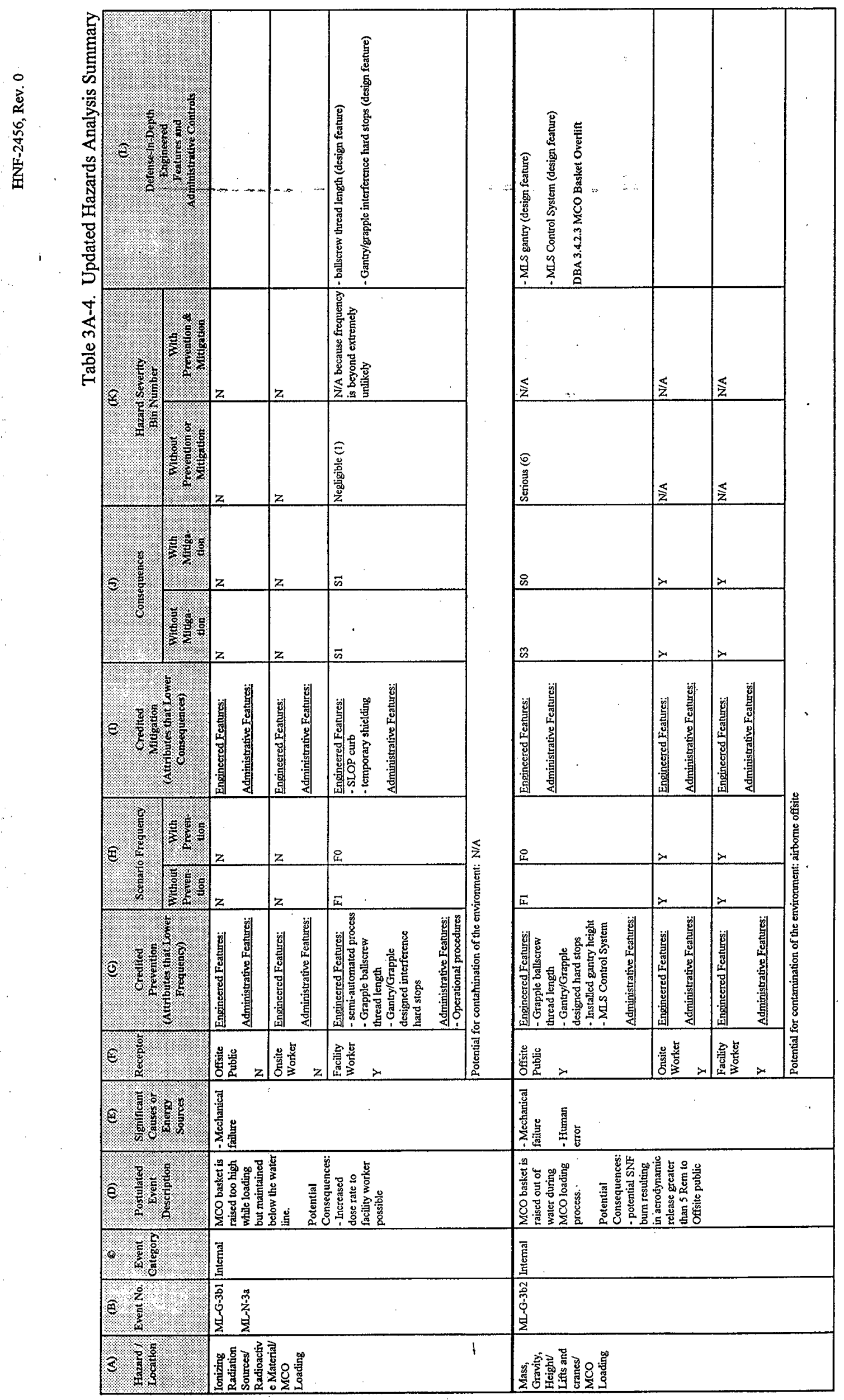

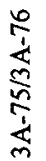




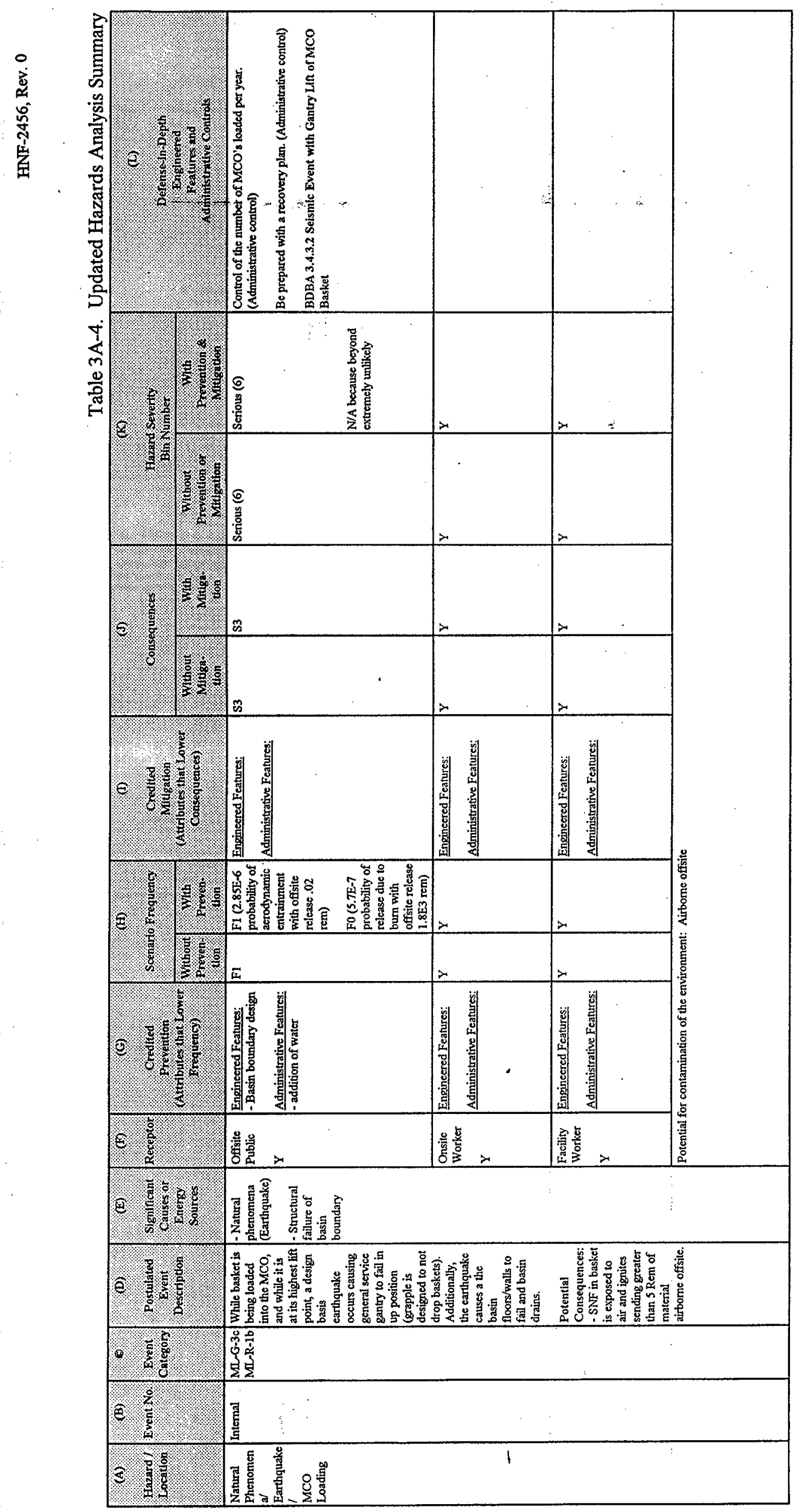

交 


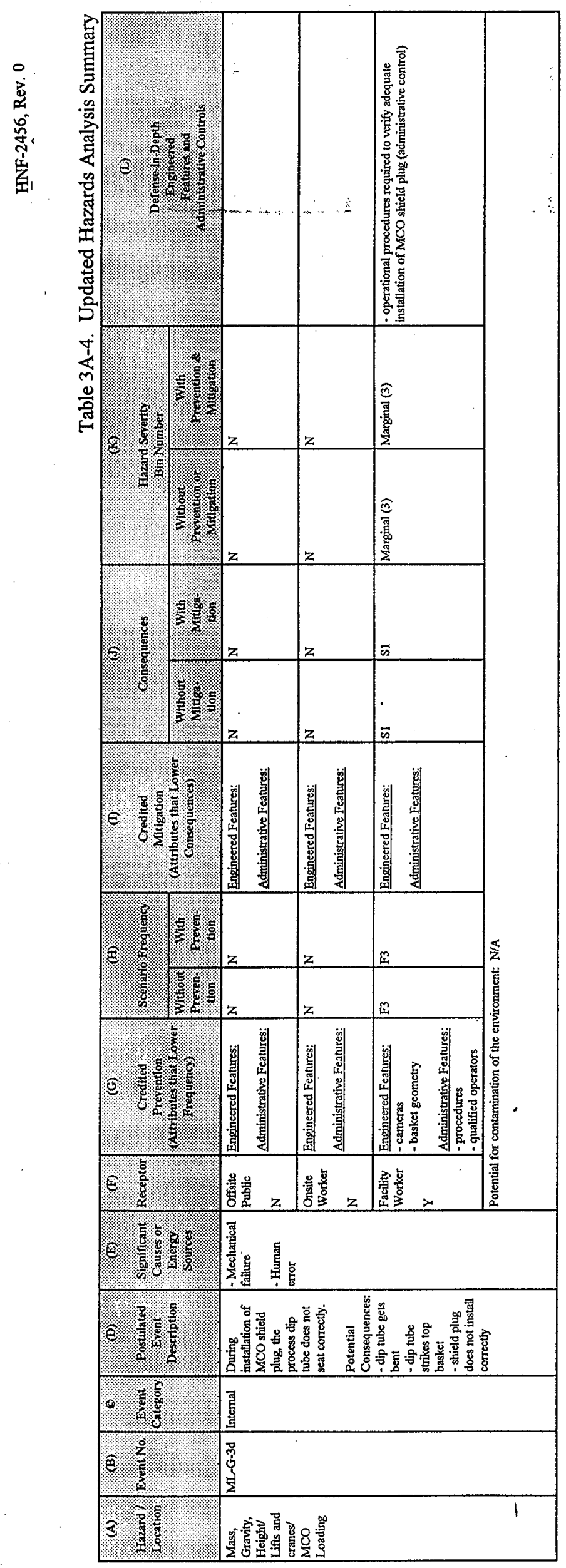

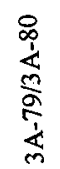




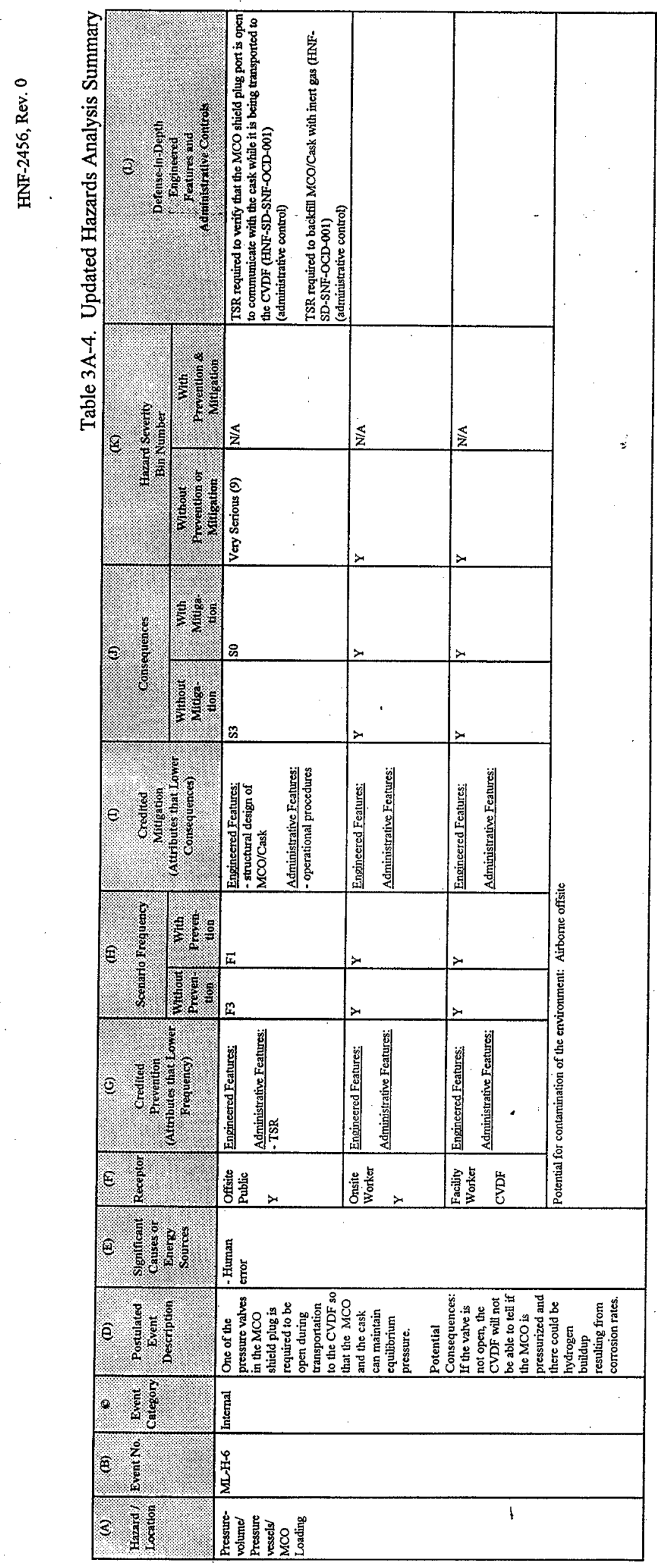

\} 


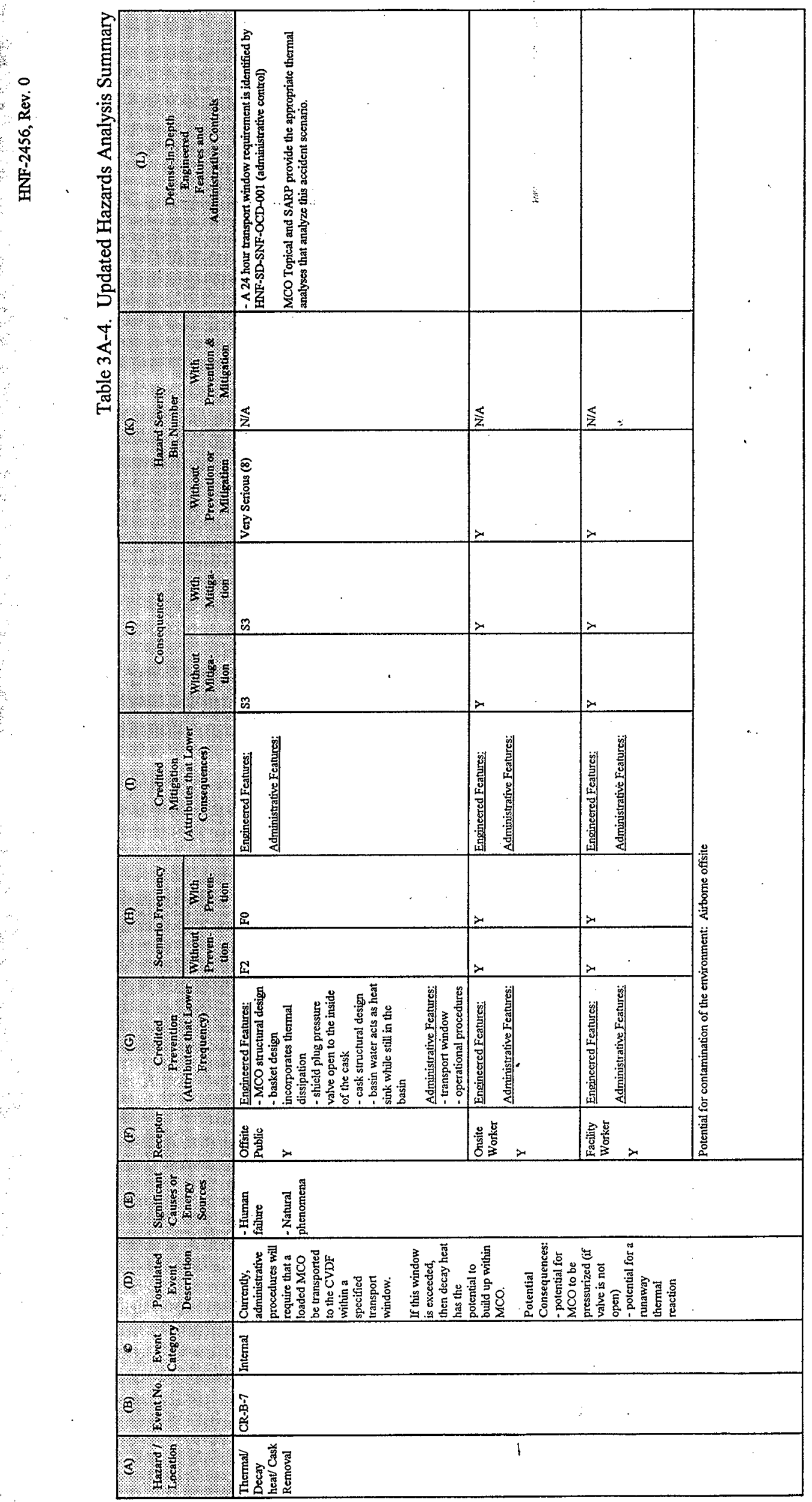

㐫 


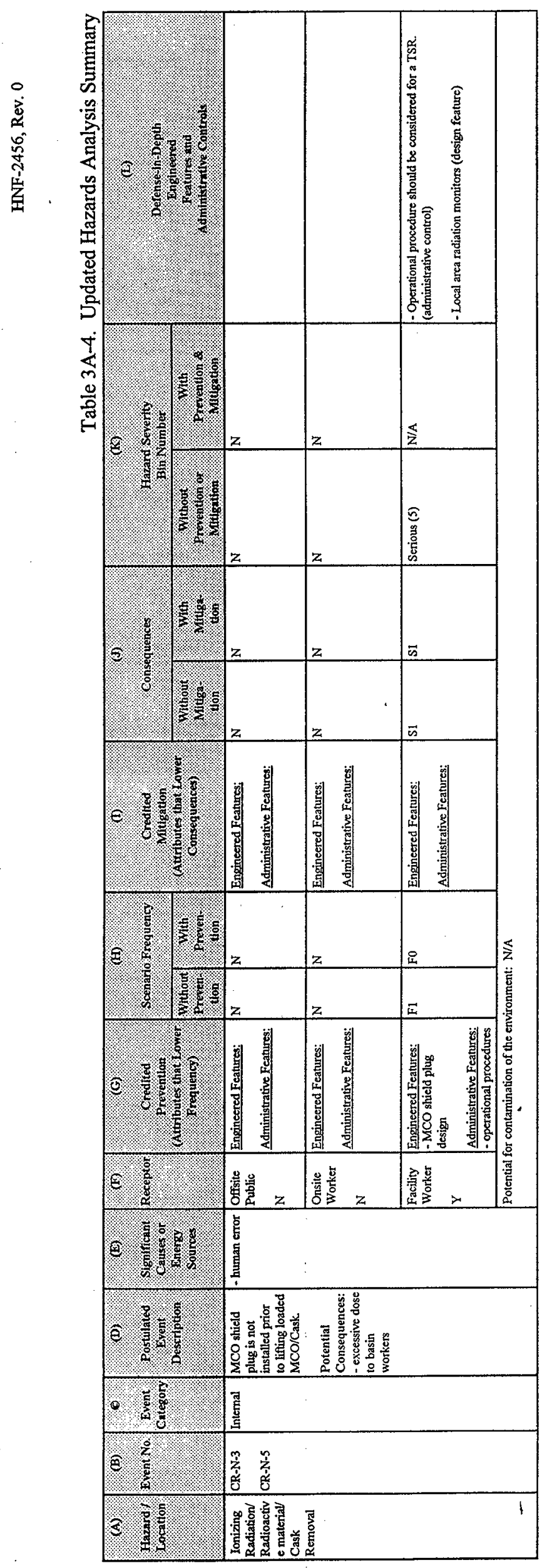

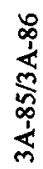


HNF-2456, Rev. 0

APPENDIX 3B

HAZARDS IDENTIFICATION SUPPORTING CLS

EQUIPMENT INSTALLATION 
HNF-2456, Rev. 0

This page intentionally left blank. 
HNF-2456, Rev. 0

\section{APPENDIX 3B \\ HAZARDS IDENTIFICATION SUPPORTING CLS EQUIPMENT INSTALLATION}

The following team conducted a hazards identification and assessment review to support installation of cask loadout system equipment, as required by spent nuclear fuel administrative procedure 4-015, Spent Nuclear Fuel Project Hazard and Safety Assessment (Webb 1998).

Member

Kevin E. Ard

Dave L. Cooley

Debbey D. Faris-Zyph

Larry E. Formo

Pat M. Hickey

Vic L. Hoefer

Jerry E. Kurtz

Mike J. Langevin

Bob H. Meichle

Leonard A. Rodgers

Dale H. Splett

Scott W. Story

Roger H. Webb

\section{Company/Group}

DE\&S Hanford, Inc. (DESH), Project

DESH, Project

DESH, Operations

Fluor Daniel Northwest (FDNW), Craft Supervisor

DESH, Occupational Health \& Safety

DESH, Facility Systems Startup

DESH, Radiation Control

DESH, Facility Engineer

DESH, Nuclear Safety

FDNW, Project

U.S. Department of Energy, Richland Operations Office

FDNW, Project Manager

Parsons, Nuclear Safety

\section{REFERENCES}

SNF AP 4-015-00, 1997, Spent Nuclear Fuel Project Hazard and safety Assessment, DE\&S Hanford, Richland, Washington

Webb, R. H., Hazard/Safety Assessment Supporting Installation of MCO Loading System Equipment and Immersion Pail, HNF-2173, March 10, 1998, DE\&S Hanford, Richland, Washington 
Table 3B-1. Hazards Identification Supporting CLS Equipment Installation.

\begin{tabular}{|c|c|c|c|c|}
\hline \multicolumn{5}{|c|}{ HAZARD ACTIVITY CHECKLIST } \\
\hline ACTIVITY/HAZARD & $\mathbf{Y}$ & $\mathbf{N}$ & COMMENT & $\begin{array}{c}\text { HAZARD } \\
\text { ELIMINATION }\end{array}$ \\
\hline Radiation Work Area & $\checkmark$ & & General Basin & $\begin{array}{l}\text { - Pre Job } \\
\text { - Trng } \\
\text { - RWP required and } \\
\text { procedures } \\
\text { - Approved Wrk Instr }\end{array}$ \\
\hline Hazard Waste Operations & & $\checkmark$ & N/A & \\
\hline Confined Space Entry & & $\checkmark$ & N/A & \\
\hline Cutting/Welding & $\checkmark$ & & $\begin{array}{l}\text { - Grating Mods } \\
\text { - Structure installation of } \\
\text { gantry support structure } \\
\text { - Obstruction removal } \\
\text { - Installation of support } \\
\text { activities } \\
\end{array}$ & $\begin{array}{l}\text { - Pre Job } \\
\text { - Trng } \\
\text { - Hot Work Permit } \\
\text { required } \\
\text { - Approved Wrk Instr }\end{array}$ \\
\hline Roof Work & & $\checkmark$ & $\mathrm{N} / \mathrm{A}$ & \\
\hline Fall Hazards & $\checkmark$ & & $\begin{array}{l}\text { Installation of : } \\
\text { - Bridge gantry } \\
\text { - Grating mods } \\
\text { - Shuttle installation } \\
\text { - Support utilities } \\
\end{array}$ & $\begin{array}{l}\text { - Pre Job } \\
\text { - Fall Protection Plan } \\
\text { - Barrier and Fall } \\
\text { Protection required } \\
\text { - Approved Wrk Instr }\end{array}$ \\
\hline Excavation/Trenching & & 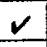 & N/A & \\
\hline Asbestos Inspection Report & $\checkmark$ & & Conduit Runs & $\begin{array}{l}\text { - Asbestos Work Permit } \\
\text { - Pre Job } \\
\text { - Trng } \\
\text { - PPE (personal } \\
\text { protective equipment) }\end{array}$ \\
\hline Hazardous Materials & $\checkmark$ & & $\begin{array}{l}\text { - Paint Material } \\
\text { - Lead }\end{array}$ & $\begin{array}{l}\text { - Waste Management } \\
\text { Plan } \\
\text { - Pre Job } \\
\end{array}$ \\
\hline Respiratory Hazards & $\checkmark$ & & $\begin{array}{l}\text { - Cutting/Grinding/Drilling } \\
\text { - General Basin may require } \\
\text { to be on mask } \\
\text { - Removal of items from } \\
\text { water }\end{array}$ & $\begin{array}{l}\text { - Pre Job } \\
\text { - Trng } \\
\text { - Approved Wrk Instr } \\
\text { - Engineered Controls } \\
\text { (e.g. fixatives, } \\
\text { containment, and local } \\
\text { exhaust lines) } \\
\text { - PPE (if required) }\end{array}$ \\
\hline
\end{tabular}


Table 3B-1. Hazards Identification Supporting CLS Equipment Installation.

\begin{tabular}{|c|c|c|c|c|}
\hline \multicolumn{5}{|c|}{ HAZARD ACTIVITY CHECKLIST } \\
\hline ACTIVITY/HAZARD & $\mathbf{Y}$ & $\mathbf{N}$ & COMMENT & $\begin{array}{c}\text { FAZARD } \\
\text { ELIMINATION }\end{array}$ \\
\hline Electrical Hazards & $\checkmark$ & & $\begin{array}{l}\text { - Installation of electrical } \\
\text { components } \\
\text { - Connection to breaker } \\
\text { panel } \\
\text { - Gantry motor/drive }\end{array}$ & $\begin{array}{l}\text { - Pre Job } \\
\text { - Trng } \\
\text { - Approved Wrk Instr } \\
\text { - Lock \& Tag permit } \\
\text { - Electrical Work Plan } \\
\text { - Zero energy checks } \\
\text { - GFI } \\
\end{array}$ \\
\hline Lock and Tag & $v$ & & $\begin{array}{l}\text { Energy sources during } \\
\text { installation } \\
\text { - Electrical } \\
\text { - Pneumatic (air) }\end{array}$ & $\begin{array}{l}\text { - L\&T permits } \\
\text { - Approved Wrk Instr }\end{array}$ \\
\hline Scaffolding & $\checkmark$ & & Installation of equipment & $\begin{array}{l}\text { - Pre Job } \\
\text { - Trng } \\
\text { - Approved Wrk Instr } \\
\text { - Qualified person } \\
\text { required to sign off for } \\
\text { approval } \\
\text { - Check once/shift by } \\
\text { qualified person } \\
\end{array}$ \\
\hline Aerial Lifts & $\checkmark$ & & Installation of gantry & $\begin{array}{l}\text { - Pre Job } \\
\text { - Trng } \\
\text { - Approved Wrk Instr } \\
\text { - Fall Protection Plan } \\
\text { - Fall Protection } \\
\end{array}$ \\
\hline Asbestos Removal & & $v$ & N/A (No abation) & \\
\hline Temperature Extremes & & $v$ & $\mathrm{~N} / \mathrm{A}$ & \\
\hline Noise & $\checkmark$ & & $\begin{array}{l}\text { General Construction } \\
\text { Activities }\end{array}$ & - Hearing Protection \\
\hline Poor Lighting & $\checkmark$ & & $\begin{array}{l}\text { - Under-water Lights } \\
\text { - General Basin }\end{array}$ & $\begin{array}{l}\text { Available lighting } \\
\text { evaluated in pre-job } \\
\text { planning } \\
\text { - Approved Wrk Instr }\end{array}$ \\
\hline Animals/Insects & $\checkmark$ & & General Basin & $\begin{array}{l}\text { - Annual Pest Control } \\
\text { (and as needed) }\end{array}$ \\
\hline Process Chemicals/Steam & & $v$ & $\mathrm{~N} / \mathrm{A}$ & \\
\hline
\end{tabular}


Table 3B-1. Hazards Identification Supporting CLS Equipment Installation.

\begin{tabular}{|c|c|c|c|c|}
\hline \multicolumn{5}{|c|}{ HAZARD ACTIVITY CHECKLIST } \\
\hline ACTIVITY/HAZARD & $\mathbf{Y}$ & $\mathbf{N}$ & COMMENT & $\begin{array}{c}\text { HAZARD } \\
\text { ELIMINATION }\end{array}$ \\
\hline Dust & $\checkmark$ & & $\begin{array}{l}\text { General Construction } \\
\text { Activities } \\
\text { - Drilling/Grinding/Cutting } \\
\text { Steel and Concrete }\end{array}$ & $\begin{array}{l}\text { - Engineered controls } \\
\text { (local exhaust } \\
\text { ventilation) } \\
\text { - Respiratory Protection } \\
\text { Equipment } \\
\text { - Approved Wrk Instr } \\
\end{array}$ \\
\hline $\begin{array}{l}\text { Flammable/Combustible } \\
\text { Materials }\end{array}$ & $\checkmark$ & & $\begin{array}{l}\text { - Cables } \\
\text { - Epoxy paint over welds }\end{array}$ & $\begin{array}{l}\text { - Fire Protection Plan } \\
\text { - Hot Work Permit } \\
\text { - Pre Job } \\
\end{array}$ \\
\hline Ladders & $\checkmark$ & & $\begin{array}{l}\text { General Construction } \\
\text { Activities }\end{array}$ & Each shift Safety Check \\
\hline Wet/Slippery Floors & $\checkmark$ & & Filling Immersion Pail & $\begin{array}{l}\text { - Approved Wrk Instr } \\
\text { - Housekeeping } \\
\end{array}$ \\
\hline Uneven Terrain & & $\checkmark$ & N/A & \\
\hline Open Excavations/Trenches & & $\checkmark$ & N/A & \\
\hline Adjacent Water Hazard & $\checkmark$ & & $\begin{array}{l}\text { - Loadout Pit } \\
\text { - Transfer channel } \\
\text { - Main Channel } \\
\text { - Basin (by grating mods) }\end{array}$ & $\begin{array}{l}\text { - Barriers } \\
\text { - Fall Protection Plan } \\
\text { - Fall Protection } \\
\text { - Life ring flotation } \\
\text { device } \\
\text { - Approved Wrk Instr }\end{array}$ \\
\hline Vehicle Traffic & $\checkmark$ & & $\begin{array}{l}\text { - Forklifts } \\
\text { - JLG } \\
\text { - Trucks }\end{array}$ & $\begin{array}{l}\text { - Process to enter } \\
\text { - Trmg } \\
\text { - Approved Wrk Instr }\end{array}$ \\
\hline Heavy Equipment & & $\checkmark$ & N/A & \\
\hline Rigging Operation & $\checkmark$ & & $\begin{array}{l}\text { Installation activities } \\
\text { - Shuttle } \\
\text { - Immersion pail } \\
\text { - Gantry section structural } \\
\text { members } \\
\text { - Misc components } \\
\end{array}$ & $\begin{array}{l}\text { - Hoisting \& Rigging } \\
\text { Manual Requirements } \\
\text { - Critical lift procedures } \\
\text { - Approved Wrk Instr }\end{array}$ \\
\hline Manual Lifting & $\checkmark$ & & $\begin{array}{l}\text { General Construction } \\
\text { Activities }\end{array}$ & $\begin{array}{l}\text { - Pre Job } \\
\text { - Trng } \\
\text { - PPE (back support) }\end{array}$ \\
\hline
\end{tabular}


Table 3B-1. Hazards Identification Supporting CLS Equipment Installation.

\begin{tabular}{|c|c|c|c|c|}
\hline \multicolumn{5}{|c|}{ HAZARD ACTIVITY CHECKLIST } \\
\hline ACTIVITY/HAZARD & $\mathbf{Y}$ & $\mathbf{N}$ & COMMENT & $\begin{array}{c}\text { HAZARD } \\
\text { ELIMINATION }\end{array}$ \\
\hline Power Tools & $\checkmark$ & & $\begin{array}{l}\text { - Hoist } \\
\text { - Drills } \\
\text { - Grinders } \\
\text { - Sawzalls } \\
\text { - Hydraulic cutters } \\
\text { - etc. } \\
\text { (for installation activities) }\end{array}$ & $\begin{array}{l}\text { - Pre Job } \\
\text { - Trng } \\
\text { - PPE (safety glasses, } \\
\text { safety shoes, gloves, } \\
\text { hearing protection) } \\
\text { - Approved Wrk Instr }\end{array}$ \\
\hline Pinch Points & $\checkmark$ & & $\begin{array}{l}\text { General Construction } \\
\text { Activities } \\
\text { - lifts } \\
\end{array}$ & $\begin{array}{l}\text { - Pre Job } \\
\text { - PPE (gloves) }\end{array}$ \\
\hline Falling Objects & $\checkmark$ & & $\begin{array}{l}\text { - Tools and equipment used } \\
\text { during installation } \\
\text { - MLS components }\end{array}$ & $\begin{array}{l}\text { - Pre Job } \\
\text { - PPE (hard hats, safety } \\
\text { shoes) } \\
\text { - Housekeeping } \\
\end{array}$ \\
\hline Sharp Objects & $\checkmark$ & & $\begin{array}{l}\text { - General Construction } \\
\text { Activities } \\
\text { - Cutting/Grinding/Welding }\end{array}$ & $\begin{array}{l}\text { - Pre Job } \\
\text { - Trng } \\
\text { - PPE (gloves) }\end{array}$ \\
\hline Overhead Obstructions & $\checkmark$ & & $\begin{array}{l}\text { - Monorail } \\
\text { - Electrical wiring } \\
\text { installation activities }\end{array}$ & $\begin{array}{l}\text { - Pre Job } \\
\text { - PPE (hard hats) }\end{array}$ \\
\hline Site Control (Signs/Barricades) & $\checkmark$ & & $\begin{array}{l}\text { - Barriers around open water } \\
\text { - Radiological hazards } \\
\text { - High noise areas }\end{array}$ & $\begin{array}{l}\text { - Pre Job } \\
\text { - Trng } \\
\text { - PPE (safety glasses) } \\
\text { - Approved Wrk Instr } \\
\end{array}$ \\
\hline Remote Work Area & & $\checkmark$ & N/A & \\
\hline Compressed Gasses & $\checkmark$ & & $\begin{array}{l}\text { - Shuttle transfer equipment } \\
\text { - Grapple } \\
\text { - Acetylene bottles }\end{array}$ & $\begin{array}{l}\text { - Pre Job } \\
\text { - Trng } \\
\text { - Proper storage } \\
\end{array}$ \\
\hline Tripping & $\checkmark$ & & $\begin{array}{l}\text { - Power cords } \\
\text { - Camera cords } \\
\text { - Curbs } \\
\text { - Grating } \\
\text { - General Construction } \\
\text { Activities }\end{array}$ & $\begin{array}{l}\text { - Pre Job } \\
\text { - Marking and Securing } \\
\text { - Housekeeping }\end{array}$ \\
\hline
\end{tabular}


HNF-2456, Rev. 0

This page intentionally left blank. 
HNF- 2456, Rev. 0

\subsection{SAFETY STRUCTURES, SYSTEMS, AND COMPONENTS}

\subsection{NTRODUCTION}

This chapter provides details of the safety-class structures, systems, and components (SSC) and safety-significant SSCs needed for the cask loadout system (CLS) equipment to ensure protection of onsite workers, the public, and the environment. The chapter describes the attributes required to support the safety functions identified in the hazard and accident analyses and to support subsequent derivations of the facility technical safety requirements (TSR) associated with cask loadout equipment and operation.

\subsection{REQUIREMENTS}

The facility standards and criteria that apply to the CLS are found in the SNF K Basin and Cold Vacuum Drying Facility Standards/Requirements Identification Document, HNF-SD-SNF-RD-001 (DESH 1998a).

The specific standards and requirements that apply to CLS equipment and components are found in WHC-S-0396, Performance Specification for TN-WHC Cask and Transportation System (Kee 1995), and WHC-S-0546, Specification for SNF $K$ East and $K$ West MCO Loading System (Brisbin 1997a). The standards and requirements that apply to the multi-canister overpack (MCO) are found in HNF-S-0426, Performance Specification for the Spent Nuclear Fuel Project Multi-canister Overpack (DESH 1998b).

\subsection{SAFETY-CLASS STRUCTURES, SYSTEMS, AND COMPONENTS}

This section discusses engineered safety features used in the design of the CLS equipment to ensure protection of onsite workers, the public, and the environment. The two safety designations are safety class and safety significant. Safety-class SSCs are selected based on the need to mitigate accident consequences to the public that are greater than the risk evaluation limits. A safety-class SSC is "an SSC whose preventive or mitigative function is necessary to keep radiological exposure to within the offsite radiological risk guidelines or to prevent a nuclear criticality" (FDH 1997). Safety-class SSCs are discussed in Sections 4.3.1 through 4.3.5.

The criteria for safety-class determination of SSCs as applied to the CLS equipment are found in Appendix 4A, Table 4A-1.

The cask and transportation system (CTS) does not add any permanent modifications or equipment to either basin. This safety analysis document (SAD) covers safety analysis of the CTS as it is affected by the cask loadout process. The CTS safety analysis and supporting SSC safetyclass determination are provided in HNF-SD-TP-SARP-017, Safety Analysis Report for Packaging (Onsite) Multi-Camister Overpack Cask (Edwards 1998). The cask is classified as transportation safety-class I (Edwards 1998). 
HNF- 2456, Rev. 0

The MCO, which fits inside the cask, contains safety SSCs identified by HNF-S-0426, Performance Specification for the Spent Nuclear Fuel Project Multi-canister Overpack (DESH 1998b).

The safety equipment list for the CLS is presented in Table 4-1. No safety-significant SSCs were identified among the SSCs covered by the scope of this document.

\subsubsection{Immersion Pail Support Structure}

The immersion pail support structure (IPSS) performs its safety function in conjunction with the immersion pail.

4.3.1.1 Safety Function. The safety function of the IPSS is to absorb enough energy to prevent a perforation of the safety-class basin boundary (i.e., south loadout pit floor and walls) that might result from a high-energy impact load caused by the Cask-MCO drop into the south loadout pit design basis accident (DBA) (Section 3.4.2.1).

4.3.1.2 Description. The IPSS is a two-part steel frame structure approximately $320 \mathrm{in}$. high (See Figure 4-1). It is fabricated from carbon steel and coated to protect it against corrosion over the life of the system. Leveling feet are provided between each set of corner column tube-steel supports for initial structure installation and alignment into the loadout pit. Once the correct alignment is established, the IPSS is physically wedged into place by manually operated jacks. The IPSS base plate is made of steel and is 48.06 in. $\times 56.87$ in. $\times 1.5$ in. thick. The weight load of the immersion pail and cask is transmitted through the IPSS to the IPSS base plate (Brisbin 1997b).

Manually operated locking pin assemblies are mounted to the top of each IPSS corner column. The IPSS locking pins are designed to be locked in the full-open or full-closed position. During typical cask loadout operations, the IPSS locking pins support the immersion pail in the top position. However, the IPSS locking pins also will absorb energy as they deform and shear during a DBA (Section 3.4.2.1).

4.3.1.3 Functional Requirements. The IPSS must be able to absorb energy and withstand drop loads and seismic forces to the extent that a basin boundary perforation is prevented.

4.3.1.4 System Evaluation. The immersion pail support structure was procured general service and will undergo a safety upgrade before installation and operation. The upgrade includes the following:

- Verifying through detailed bounding analysis that the equipment as designed can support the safety function

- Identifying the critical design parameters (e.g., physical dimensions, material specifications, weld types, etc.) that support the safety functional requirements (determined by the design authority) 
HNF- 2456, Rev. 0

- Identifying the minimum acceptance criteria for the critical parameters (determined by the design authority)

- Verifying through physical inspection that the as-fabricated IPSS critical design parameters meet the minimum acceptance criteria

- Generating a safety-class upgrade package to support the IPSS being designated safety class (See Table 4-1).

Analysis to support the functional requirements has already been performed (Chenault 1997 and 1998). The IPSS can withstand the impact of the Cask-MCO drop into the south loadout pit DBA (Section 3.4.2.1) without catastrophic structural failure or tipping. It also is capable of withstanding the loads imposed by the design basis earthquake without structural failure or tipping because the seismic loads are bounded by the loads imposed by the dropped Cask-MCO. The seismic analysis provided in the hazards and operability study (Webb 1998) demonstrates that the Cask-MCO suspended in the IPSS does not have enough energy to cause unacceptable damage to the loadout pit wall during a seismic event. These analyses show that the IPSS can perform the safety functions as designed and will withstand the postulated accident conditions with acceptable margins. The analyses evaluated conditions that bounded the accident conditions to provide a high degree of conservatism. The IPSS is adequately designed to prevent perforation of the safety-class basin boundary.

All safety-related load path components of the IPSS are designed in accordance with American National Standards Institute (ANSI) NI 4.6 for the transportation cask dead weight. Applicable design criteria from the American Institute of Steel Construction (AISC) and American Society of Mechanical Engineers (ASME) boiler pressure vessel code have been adopted to evaluate the IPSS for loads other than tension loading to supplement ANSI N14.6 for the transportation cask dead weight (Brisbin 1997b).

4.3.1.5 Controls (TSR). The IPSS is a passive design feature; however, its integrity must be maintained. Because this equipment has a limited life-less than 5 years - it is not expected to experience significant degradation from corrosion while in service in the basin. The Spent Nuclear Fuel Project design control program will ensure design changes are reviewed for safety impact and approval before their implementation (DOE 5480.21). No additional or special controls are required.

All four immersion pail support structure locking pins must be in place to hold the immersion pail in the top immersion pail support structure position during cask insertion and removal. The analysis for a fully loaded cask drop into the immersion pail when it is pinned in the top position of the immersion pail support structure credits some energy absorption to the drop forces transferred through the immersion pail to the immersion pail support structure through the locking pins (Chenault 1998). A TSR is proposed to ensure that the bounding analysis is maintained. 
HNF-2456, Rev. 0

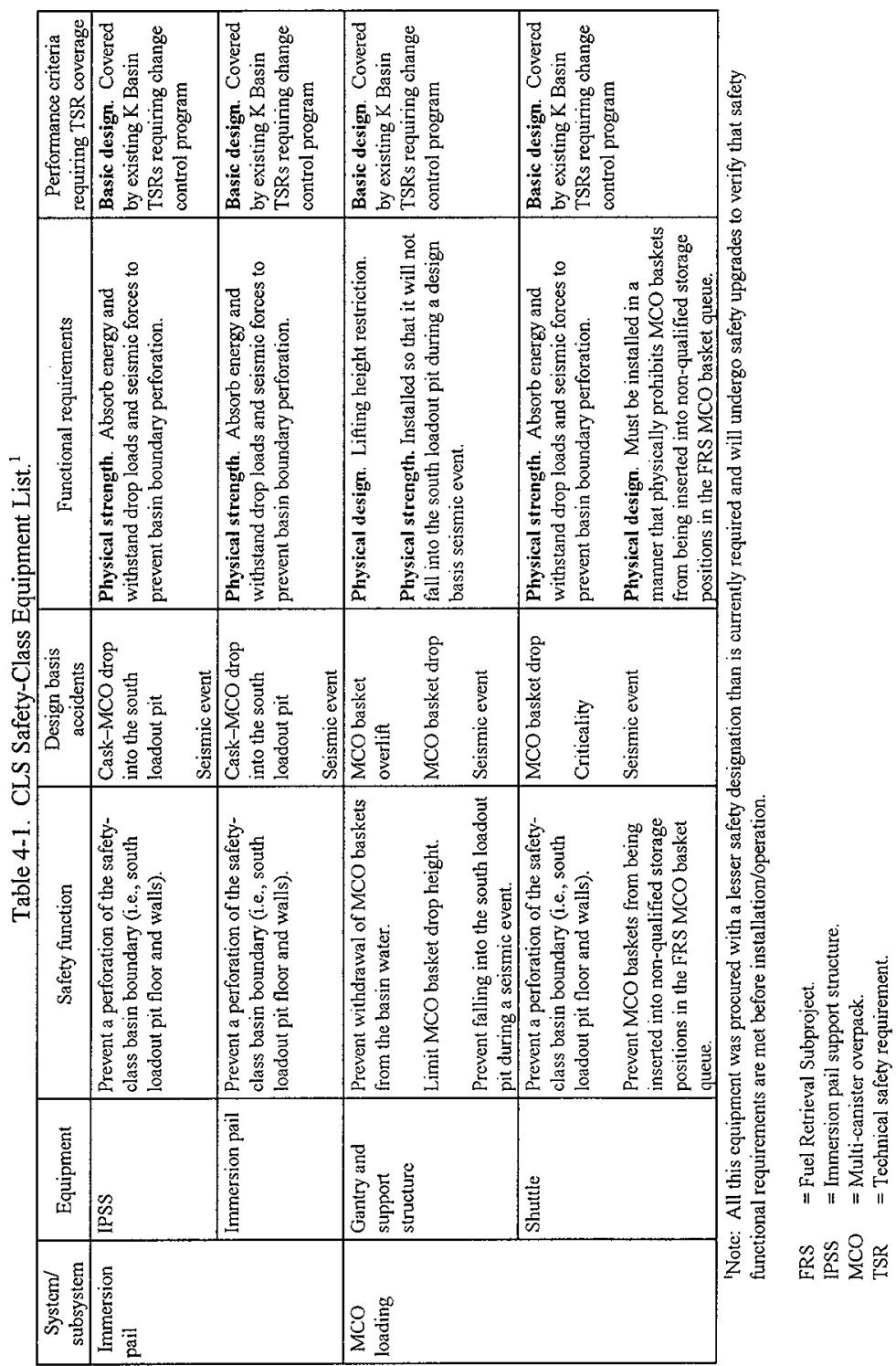


HNF- 2456, Rev. 0

\subsubsection{Immersion Pail}

The immersion pail performs the safety function in conjunction with the immersion pail support structure (IPSS).

4.3.2.1 Safety Function. The safety function of the immersion pail is to absorb enough energy to prevent the perforation of the safety-class basin boundary (i.e., south loadout pit floor and walls), which might result from a high-energy impact load caused by the Cask-MCO drop into the south loadout pit DBA (Section 3.4.2.1).

4.3.2.2 Description. The immersion pail is a thin-walled cylinder $165.5 \mathrm{in}$. long made of 304 stainless steel (See Figure 4-2). Although it contains a sealed foam-filled floatation cavity to aid in decreasing operational loads, the foam itself does not perform a safety function. The buoyant forces produced by the immersion pail water displacement were used in the safety analysis (Chenault 1998). The immersion pail base plate is fabricated from 2-in.-thick 304 stainless steel and carries the cask load to the pail wall, which uniformly transmits the cask load in tension to the top shell ring structure and four immersion pail lifting lugs. The lifting lugs are fabricated from 1.5-in.-thick carbon steel. The lifting lugs interface with the IPSS locking pins and IPSS or the transfer bay crane lift slings. The cross-section envelop of the immersion pail is $42.75 \mathrm{in}$. by $53.5 \mathrm{in}$. When located in the top position, the immersion pail transmits the weight of the cask load to the IPSS through the IPSS locking pins. The immersion pail transmits the weight of the cask load to the IPSS base plate when the immersion pail and cask are located on the floor of the south loadout pit for the MCO loading operations (Brisbin 1997b).

4.3.2.3 Functional Requirements. The equipment must be able to absorb energy and withstand drop loads and seismic forces to the extent that they prevent basin boundary perforation.

4.3.2.4 System Evaluation. The immersion pail was procured general service and will undergo a safety upgrade before installation and operation. The upgrade includes the following:

- Verifying through detailed bounding analysis that the equipment as designed can support the safety function

- Identifying the critical design parameters (e.g., physical dimensions, material specifications, weld types, etc.) that support the safety functional requirements (determined by the design authority)

- Identifying the minimum acceptance criteria for the critical parameters (determined by the design authority)

- Verifying through physical inspection that the as-fabricated immersion pail critical design parameters meet the minimum acceptance criteria

- Generating a safety-class upgrade package to support the immersion pail being designated safety-class (See Table 4-1). 
Analysis to support the functional safety requirements has already been performed (Chenault 1997 and 1998). These analyses demonstrate the design's ability to withstand the postulated accident conditions with acceptable margins. The analyses evaluated conditions that bounded accident conditions to provide a high degree of conservatism. The immersion pail can withstand the impact of the load during the Cask-MCO drop into the south loadout pit DBA (Section 3.4.2.1). Loads imposed by the design basis earthquake are bounded by the dropped Cask-MCO accident, which has been shown to occur without structural failure or tipping. The seismic analysis provided in the hazards and operability study, HNF-2201, Hazards and Operability Study for SNF Cask/MCO Loading System (Webb 1998) shows that the Cask-MCO suspended in the immersion pail does not have enough energy to cause unacceptable damage to the loadout pit wall during a seismic event.

All safety-related load path components of the immersion pail are designed in accordance with ANSI N14.6 for the transportation cask dead weight. Applicable design criteria from the AISC and ASME boiler pressure vessel code have been adopted to evaluate the immersion pail for loads other than tension loading to supplement ANSI N14,6 for the transportation cask dead weight (Brisbin 1997b).

4.3.2.5 Controls (TSRs). The immersion pail is a passive design feature. Because this equipment has a limited life-less than 5 years-it is not expected to experience significant degradation from corrosion while in service in the basin. The Spent Nuclear Fuel Project design control program will ensure design changes are reviewed for safety impact and approval before their implementation (DOE 5480.21). Administrative controls on the IPSS pin engagement before Cask-MCO removal from the immersion pail will ensure acceptable DBA analysis results.

\subsubsection{Gantry and Support Structure}

4.3.3.1 Safety Function. The safety functions of the gantry are as follows:

- $\quad$ To prevent the DBA, MCO Basket Overlift (Section 3.4.2.3)

- To limit the height from which an MCO basket can be dropped

- The gantry and its support structure are required to withstand the loads associated with a seismic event without tipping or falling into the south loadout pit (See Table 4-1).

4.3.3.2 Description. The gantry is bolted on painted, carbon steel I-beam (W10X45) rectangular frames (gantry support structure) Hilti ${ }^{1}$-bolted to the operations deck so that it spans the south loadout pit from north to south (see Figure 4-3). The support structure also is attached to the existing W6X45 platform columns and is reinforced with W6 tube steel bracing. The gantry support structure is designed to withstand a design basis earthquake (Moody 1998). The gantry

\footnotetext{
${ }^{1}$ Hilti is a trademark of Hilti, Inc., Tulsa, Oklahoma.
} 
will undergo a safety upgrade so that it will not fall into the south loadout pit before, during, and after a seismic event. The gantry moves up and down and from the MCO basket unload position on the east side of the south loadout pit west to the MCO load position. Its horizontal movement is limited by its 57 -in. width and hard stops at each end of its route. It is designed so that it cannot move north or south once it is installed. The gantry and its support structure are designed to be installed so that it can lift an MCO basket to a maximum elevation of $-8 \mathrm{ft} 0 \mathrm{in}$.

(Brisbin 1997a).

The gantry is rated for a 3,200-1b live load. The mast weldment is made from mostly ASTM A36 carbon steel standard structural shape components. The rail subassembly that attaches to the gantry support structure is stainless steel. The grapple subassembly is made from stainless steel components. Most are 304 stainless steel; however, there are a few that are 17-4PH or Carpenter Custom 455 (Brisbin 1997c). The guide subassembly is mostly stainless steel.

The mast is a linear-guided ballscrew drive that grapples and picks the MCO basket from its unload position in the shuttle and places it into the MCO. The ballscrew is driven by a servo motor, controller, and gear box for infinitely programmable positioning capabilities. The ballscrew provides the lifting mechanism. Lift height is limited by the ballscrew thread length, guide tubes, slide bottom, and grapple hard-stop interferences working together. The mast control servo-motor stops by either reaching an elevation of 0.0 in. (as measured by the resolver) or tripping one of the redundant limit switches. If any of the design features fail, the mast slide bottom and collar will collide with the guide subassembly. If the mast is still moving, the ballscrew will run out of thread length and cease to provide lift capability (Brisbin 1997c).

4.3.3.3 Functional Requirements. The functional requirements to support the safety functions are as follows.

- The gantry must be installed so that an MCO basket cannot be lifted higher than the fixed elevation of $-8 \mathrm{ft} 0 \mathrm{in}$.

- The gantry must be installed so that it will not fall into the south loadout pit during a design basis earthquake with or without an MCO basket suspended.

4.3.3.4 System Evaluation. The gantry was procured general service and will undergo a safety upgrade before installation and operation. The upgrade includes the following:

- Verifying through detailed bounding analysis that the equipment as designed can support the safety function

- Identifying the critical design parameters (e.g. physical dimensions, material specifications, weld types, etc.) that support the safety functional requirements (determined by the design authority)

- Identifying the minimum acceptance criteria for the critical parameters (determined by the design authority) 
HNF- 2456, Rev. 0

- Verifying through physical inspection that the as-fabricated gantry critical design parameters meet the minimum acceptance criteria

- Generating a safety-class upgrade package to support the gantry being designated safety-class (See Table 4-1).

WHC-S-0546, Specification for SNF K East and K West MCO Loading System (Brisbin 1997a), requires the $\mathrm{MCO}$ loading system (MLS) to limit the MCO basket lift height to $-8 \mathrm{ft} 0$ in. elevation. Figure 4-4 shows an elevation view of the gantry installed on the support structure with a phantom basket lifted in its highest load position. Figure 4-5 shows the grapple assembly in its fully raised position. As mentioned in Section 4.3.3.3, the primary mast control is provided with redundant electrical limit switches. However, there are physical design features that prevent the overlift from occurring. The ballscrew drive provides the lift mechanism. The ballscrew thread length is fixed to provide no more lift than to a height of $-8 \mathrm{ft} 0 \mathrm{in}$. elevation. Also, the grapple assembly itself bottoms out on the gantry structure, as shown in Figure 4-5. Physical hard stops provided by component interference and lift capability limits from the ballscrew drive prevent the gantry from overlifting an MCO basket (Brisbin 1997c).

WHC-S-0546, Performance Specification for SNF $K$ East and $K$ West MCO Loading System (Brisbin 1997a) and HNF-SD-SNF-DR-004, Rev. 1, Design Report for the Hanford $K$ East and K West Basin, MCO Loading System (Brisbin 1997c), define specific minimum interface design criteria for the gantry support structure. AISC N690, Specification for the Design, Fabrication and Erection of Steel Safety-related Structures for Nuclear Facilities (ANSI/AISC N690-1984), and the Mamual of Steel Construction, Allowable Stress Design, 9th Edition (AISC 1989), define the loading conditions (Section Q1.3) and load combinations (Section Q1.3.6 and Table Q1.5.7.1) used in designing the gantry support structure. The AISC Manual of Steel Construction, 9th Edition, provides the allowable stress criteria used in designing the gantry support structure.

The gantry support structure is designed to withstand a design basis earthquake as defined by SDC- 4.1, Standard Arch-Civil Design Criteria, Design Load for Facilities, Rev. 12 (DOE-RL 1993). The gantry and support structure are classified as safety-class equipment. Peak acceleration factors for a $0.2 \mathrm{~g}$ near-field design basis earthquake event as defined in SDC 4.1 , Figure 3, including an additional factor of 1.5 to account for inter-modal participation, are incorporated in the structures design.

As reported in HNF-2052, Rev. 1, draft, Multi-canister Overpack Loading System Anchorage Analyses for $105 \mathrm{KW}$ and $105 \mathrm{KE}$ (Moody 1998), in accordance with HNF- SD-SNFDR-004, 3 separate load positions and 11 load cases (AISC N690) per load position are considered in the analysis. The first six load cases consider, individually, the dead weight of the gantry and self-weight of the structure (DL), the fuel basket lifted load or live load (LL), the impact load (I) from the movable gantry, and the three directional seismic loading conditions. Load case seven combines DL and LL. Load case eight combines DL, LL, and I. Load case nine combines the three seismic load cases using the square root of the sum of the squares (SRSS) method. Load cases 10 and 11 combine the absolute sum of load cases 7 and 8 to the SRSS load 
HNF - 2456, Rev. 0

case 9. The resulting worst case reactions and loads, and stress values considering all the analyzed load cases were used to evaluate each individual component.

The resulting minimum margin of safety based on design allowables for the gantry support structure components is 0.1 This occurs in the tension and shear force interaction equation for the new column anchor bolts under a worst case accident loading condition; i.e., dead load, live load, and seismic loading combination. Other margins of safety range from 0.12 for the new column base plate stress, to 28.3 for the sideways web buckling strength of the W10X45 main support beam.

The bridge and mast of the gantry function as a crane and meet the requirements of 29 CFR 1910.179, "Overhead and Gantry Cranes," as contained in the MLS design report (Brisbin 1997c). Applicable sections of ASME B30.11, Monorails and Underhung Cranes (ASME 1993a), and ASME B30.16, Overhead Hoists (Underhming) (ASME 1993b), as identified in the MLS design report (Brisbin 1997c), were used as guidance for the design, testing, and fabrication of the gantry. The power and controls for the gantry are designed in accordance with the general rules of NFPA 70, National Electrical Code (NFPA 1993), with particular attention given to Article 610, "Cranes and Hoists."

4.3.3.5 Controls (TSRs). The gantry is a passive design feature. Because this equipment has a limited life-less than 5 years - it is not expected to experience significant degradation from corrosion while in service in the basin. The Spent Nuclear Fuel Project design control program will ensure that design changes are reviewed for safety impact and approved before their implementation (DOE 5480.21). Physical verification of the installed gantry during acceptance testing must be performed to verify that the gantry is installed as designed to prevent an MCO basket overlift.

\subsubsection{MCO Loading System Shuttle}

4.3.4.1 Safety Function. The safety functions of the MLS shuttle are as follows:

- To prevent a perforation of the safety-class basin boundary during a DBA ("MCO Basket Drop," Section 3.4.3.4, and "Seismic Event," Section 3.4.3.5)

- To prevent MCO baskets from being inserted into non-qualified storage positions in the Fuel Retrieval Subproject (FRS) MCO basket queue.

4.3.4.2 Description. The MLS shuttle has approximately $11.5 \mathrm{ft}$ of travel horizontally through the transfer channel adjacent to the south loadout pit. The shuttle is fabricated of 304 stainless steel. The cart moves on corrosion-resistant linear-motion rollers on parallel rails. The rails are suspended from a structural steel framework anchored to the operations floor. This framework spans the transfer canal without interfering with existing structures. The shuttle has seismic restraints (capable of withstanding a $0.2 \mathrm{~g}$ design basis earthquake) attached to the upright framework to prevent up-down and north-south movement, as well as wedges that prevent eastwest movement. The shuttle is installed so that the east end of the frame is situated directly above 
the FRS MCO basket queue (Brisbin 1997c). The shuttle frame physically covers two storage positions in the FRS MCO basket queue. These positions are not qualified for basket storage, so the shuttle position prevents baskets from being inserted into non-qualified positions.

The shuttle design is being modified to allow it to perform the safety function of absorbing energy and preventing perforation of the safety-class basin boundary during the MCO basket drop DBA (Sections 3.4.3.4 and 3.4.3.5). Figure 4-6 is a sketch of the conceptual design. The modified shuttle will be required to be designated safety class and meet the functional requirements of "absorbing energy and withstanding drop loads and seismic forces to prevent basin boundary perforation." The shuttle was procured safety significant (for seismic qualifications) and must be upgraded to be designated safety class (See Table 4-1). The shuttle design modifications are being performed by Fluor Daniel Northwest under the specific direction of the DE\&S Hanford, Inc., MLS design authority. Design modifications will incorporate safetyclass design requirements (DOE 6430.1A). The fabrication changes to the shuttle resulting from the design modifications will be performed on the Hanford Site after the shuttle has been delivered.

4.3.4.3 Functional Requirements. The MLS shuttle functional requirements to support the safety functions are as follows.

- The MLS shuttle must absorb energy and withstand drop loads and seismic forces to prevent basin boundary perforation.

- The MLS shuttle must physically prevent MCO baskets from being inserted into non-qualified storage positions in the FRS MCO basket queue.

4.3.4.4 System Evaluation. The shuttle is 165 in. long and will be installed so the east end is situated over the FRS MCO basket queue (Figure 4-7). Installing the shuttle over the queue, adjacent to the south loadout pit transfer channel east end, will physically prevent $\mathrm{MCO}$ baskets from being placed in the two non-qualified queue storage positions. Physically verifying the location before starting operations will ensure that this requirement is met. The shuttle has been designed and analyzed to withstand a $0.2 \mathrm{~g}$ seismic event.

The shuttle installation is designed and analyzed to the following documents and their primary references:

- HNF-SD-SNF-DR-004, Rev. 1, Design Report for the Hanford K East and $K$ West Basin, MCO Loading System (Brisbin 1997a), which defines the normal and seismic loads used for the anchorage design.

- Manual of Steel Construction, Allowable Stress Design, 9th Edition (AISC 1989), which provides the allowable stress criteria used for the anchorage design

- HNF-PRO-097, Engineering Design and Evaluation, which provides the anchor bolt criteria used in the anchorage design. 
The shuttle anchorage design is analyzed by hand calculations using textbook solutions to structurally evaluate all members. These calculations use normal and seismic loads generated in the design report (Brisbin 1997c). To simplify these calculations, all loads were treated as normal operating loads. These loads were applied to the top of the east wall of the south loadout pit (Point B) and the top of the basin floor (Point A) and the south loadout pit transfer channel. The results of this analysis show that the structure meets the load and stress requirements of HNF-PRO-097, Section 4.2, and the AISC manual of steel construction. The minimum margin of safety to design allowables for the shuttle anchorage design is 0.21 . This occurs in the tension and shear force interaction equation for the Point B, 0.5-in. Hilti anchor bolts. Other component margins of safety range from 0.46 to 0.88 .

Analysis of the shuttle's ability to withstand the dropped MCO basket loads is contained in HNF-2052, Rev. 1, draft, (Multi-canister Overpack Loading System Anchorage Analyses for 105 $K W$ and $105 K E$ (Moody 1998). The shuttle analysis demonstrates the ability of the shuttle to withstand the accidental drop of the MCO basket during a seismic event.

The modified shuttle design must meet critical parameters identified by the design authority to support the shuttle safety-class safety functions (See Table 4-1).

4.3.4.5 Controls (TSRs). The MLS shuttle provides a passive design feature. Because this equipment has a limited life-less than 5 years-it is not expected to experience significant degradation from corrosion while in service in the basin. The Spent Nuclear Fuel Project design control program will ensure that design changes are reviewed for safety impact and approved before their implementation (DOE 5480.21). Physical verification of the shuttle installation over the FRS MCO basket queue before the start of operations will ensure that the safety functional requirement is met. No additional or special controls are required.

\subsection{SAFETY-SIGNIFICANT STRUCTURES, SYSTEMS, AND COMPONENTS}

No safety-significant SSCs have been identified for the CLS equipment. The transfer bay crane will be used extensively in the cask loading operations and is mentioned here because it is already classified as safety-significant (for design) in the current K Basins SAR (DESH 1998c). The transfer bay crane for the $100 \mathrm{~K}$ West Basin has been upgraded to a 32-ton capacity. The transfer bay crane for the $100 \mathrm{~K}$ East Basin is scheduled for a similar upgrade. That upgrade process will conform to all safety requirements.

\subsection{REFERENCES}

29 CFR 1910, "Occupational Safety and Health Standards," Section 1910.179, "Overhead and Gantry Cranes," Code of Federal Regulations, as amended.

AISC N690, Specification for the Design, Fabrication, and Erection of Steel Safety-Related Structures for Nuclear Facilities, American Institute of Steel Construction, Chicago, Illinois. 
ANSI 14.6, Special Lifting Devices for Shipping Containers Weighing 10,000 Pounds or More, American National Standards Institute Inc., New York.

ASME, Boiler and Pressure Vessel Code, Section III, Subsection NB, American Society of Mechanical Engineers, New York, 1992.

ASME, 1993, Monorails and Underhung Cranes, B30.11, American Society of Mechanical Engineers, New York, New York.

ASME, 1993, Overhead Hoists Underhung), B30.16, American Society of Mechanical Engineers, New York, New York.

Brisbin, S. A., 1997a, Performance Specification for SNF $K$ East and $K$ West MCO Loading System, WHC-S-0546, Rev, OD, DE\&S Hanford, Inc., for Fluor Daniel Hanford, Inc., Richland, Washington.

Brisbin, S. A., 1997b, Final Design Review Report for the TN-WHC Cask and Transportation System, HNF-SD-SNF-FDR-003, Rev. 0, DE\&S Hanford, Inc., for Fluor Daniel Hanford, Inc., Richland, Washington.

Brisbin, S. A., 1997c, Design Review Report for the MCO Loading System, HNF-SD-SNF-DR-004, Rev. 1, DE\&S Hanford, Inc., for Fluor Daniel Hanford, Inc., Richland, Washington.

Chenault, D. M., 1997, Cask Drops onto the K-Basins Immersion Pail Support Structure, HNF-1789, Rev. 0, including ECN 645704, DE\&S Hanford, Inc., for Fluor Daniel Hanford, Inc., Richland, Washington.

Chenault, D. M., 1998, Cask/Pail Drop on the K Basin Immersion Pail Support Structure Bottom Plate, HNF-1897, Rev. 0, including ECN 645075, DE\&S Hanford, Inc., for Fluor Daniel Hanford, Inc., Richland, Washington.

DESH, 1998a, SNF K Basin and Cold Vacuum Drying Facility Standards/Requirements Identification Document, HNF-SD-SNF-RD-001, Rev. 1, DE\&S Hanford, Inc., for Fluor Daniel Hanford, Inc., Richland, Washington.

DESH, 1998b, HNF-S-0426, Performance Specification for the Spent Nuclear Fuel Project Multi-Canister Overpack, Rev. 4, DE\&S Hanford, Inc., for Fluor Daniel Hanford, Inc., Richland, Washington.

DESH, 1998c, K Basins Safety Analysis Report, WHC-SD-WM-SAR-062, Rev. 3D, DE\&S Hanford, Inc., for Fluor Daniel Hanford, Inc., Richland, Washington.

DOE 5480.21, 1991, Unreviewed Safety Questions, Department of Energy, Washington, D.C.

DOE 5480.23, 1992, Nuclear Safety Analysis, Department of Energy, Washington, D.C. 
DOE 6430.1A, 1989, General Design Criteria, Department of Energy, Washington, D.C.

DOE-RL, 1993, Standard Architectural-Civil Design Criteria, Design Loads for Facilities, DOE/RL-HPS-SDC-4.1, Rev. 12, U.S. Department of Energy, Richland Operations Office, Richland, Washington.

Edwards, W. S., 1998, Safety Analysis Report for Packaging (Onsite) Multi-canister Overpack Cask, HNF-SD-TP-SARP-017, Rev. 1, draft, Waste Management Federal Services, Inc., Northwest Division, Richland, Washington.

FDH, 1997, Hazard and Accident Analysis Process, HNF-PRO-704, Rev. 0, Fluor Daniel Hanford, Inc., Richland, Washington.

HNF-PRO-097, Engineering Design and Evaluation, Fluor Daniel Hanford, Inc., Richland, Washington.

Kee, A. T., 1995, Performance Specification for TN-WHC Cask and Transportation System, WHC-S-0396, Rev. 1, Westinghouse Hanford Company, Richland, Washington.

Moody, D. A., 1998, Multi-canister overpack Loading System Anchorage Analyses for $105 \mathrm{KW}$ and $105 K E$, HNF-2052, Rev. A (draft), DE\&S Hanford, Inc., for Fluor Daniel Hanford, Inc., Richland, Washington.

NFPA, 1993, National Electrical Code, NFPA 70, National Fire Protection Association, Quincy, Massachusetts.

Webb, R. H., 1998, Hazards and Operability Study for SNF CaskMCO Loading System, HNF-2201, DE\&S Hanford, Inc., for Fluor Daniel Hanford, Inc., Richland, Washington. 
HNF- 2456, Rev. 0

This page intentionally left blank. 
HNF- 2456, Rev. 0

Figure 4-1. Immersion Pail Support Structure.



SUPPQRT STRUCTURE 
FINF- 2456, Rev. 0

Figure 4-2. Immersion Pail.

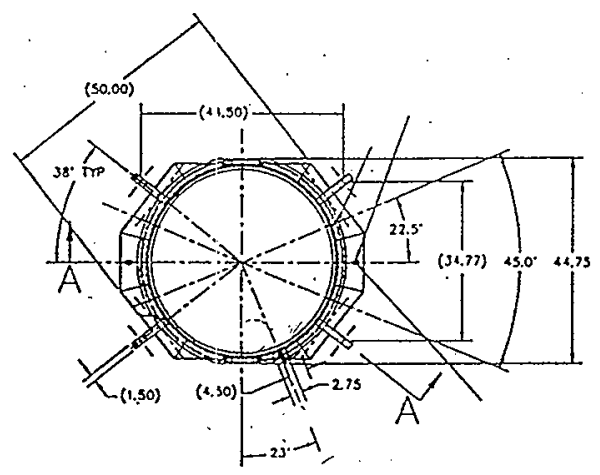

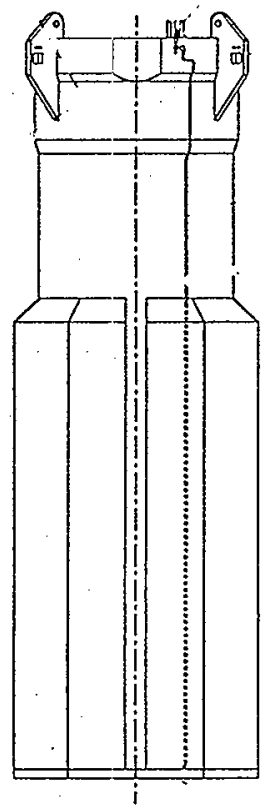

PAR ASSEMBLY

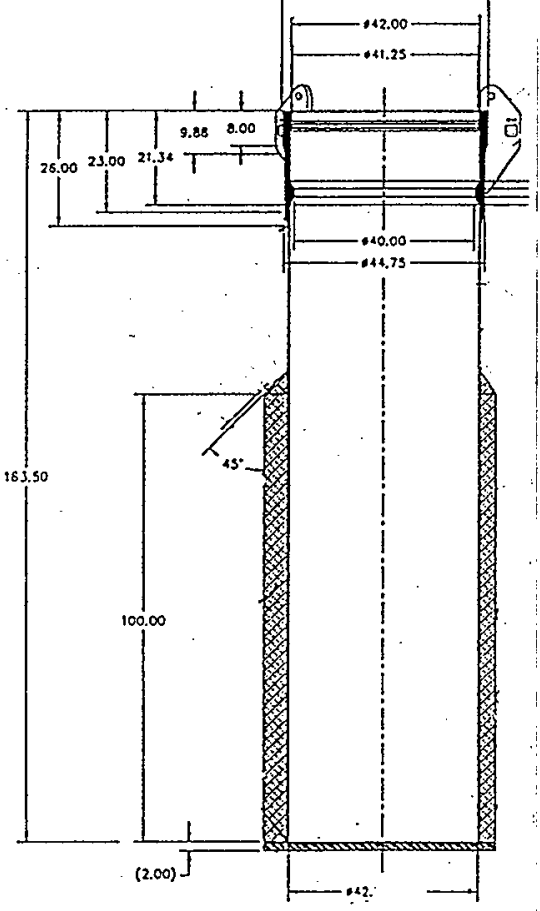

SECnON $A-A$ 
HNF- 2456, Rev. 0

Figure 4-3. Gantry with Extending Mast and Grapple.

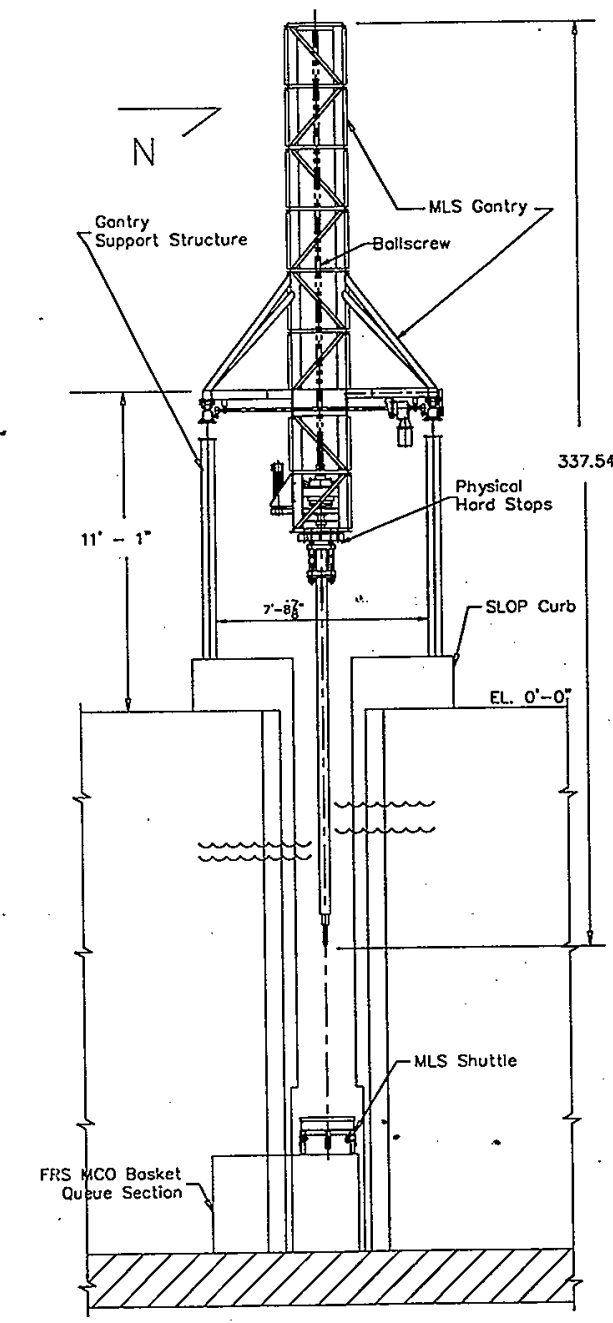


HNF- 2456, Rev. 0

Figure 4-4. Gantry Elevation View.

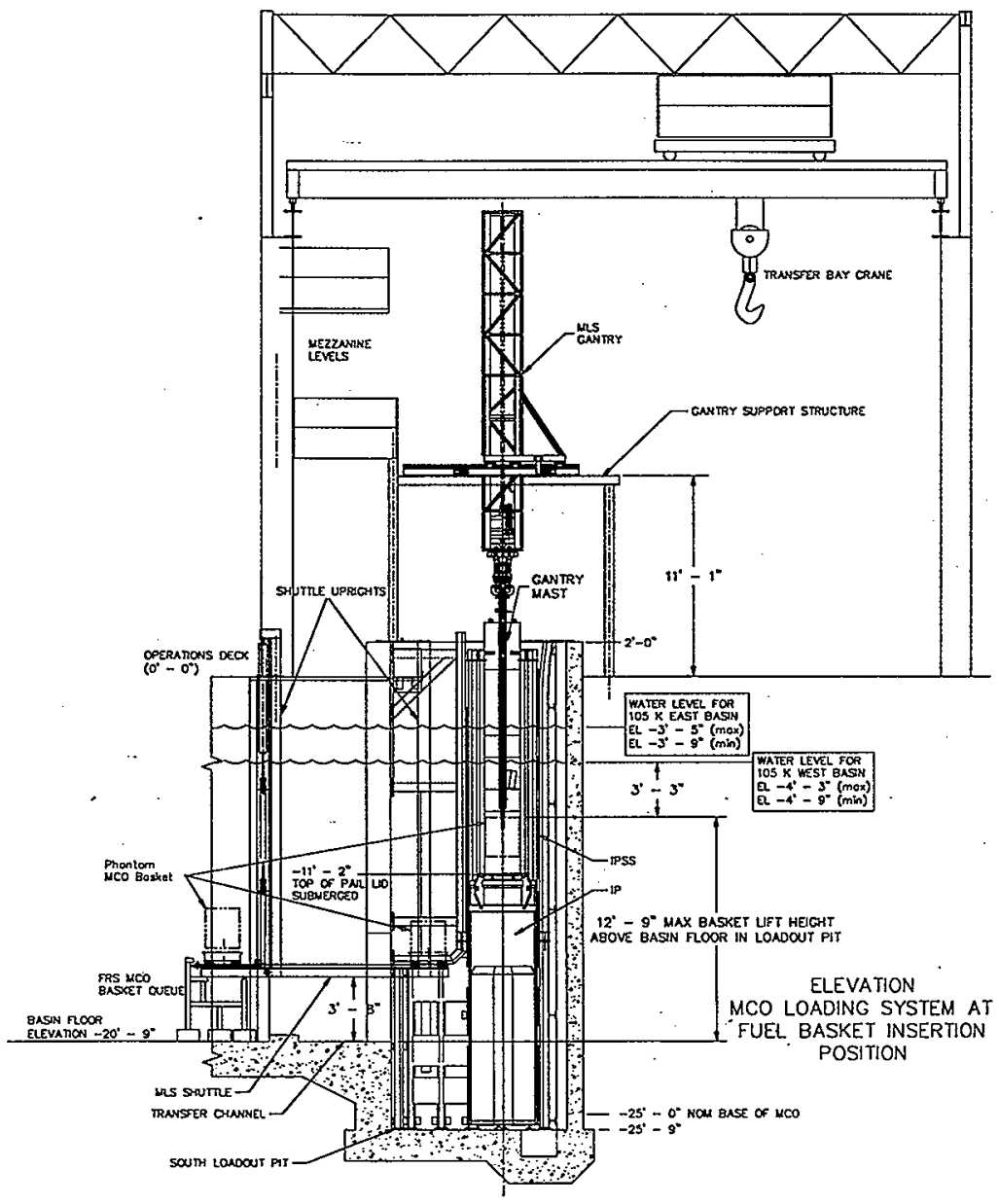


HNF- 2456, Rev. 0

Figure 4-5. MLS Shuttle.
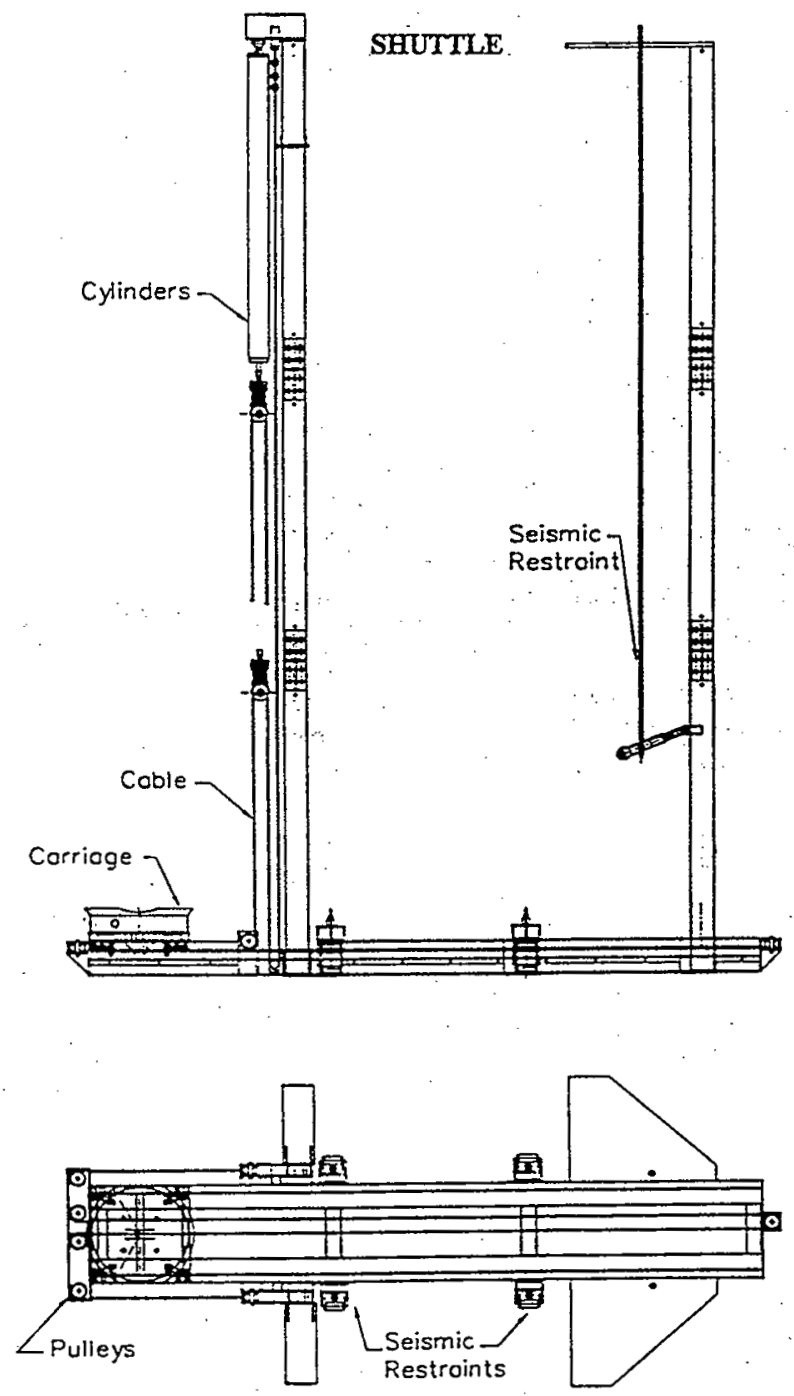
HNF- 2456, Rev. 0

Figure 4-6. MLS Shuttle Plan.

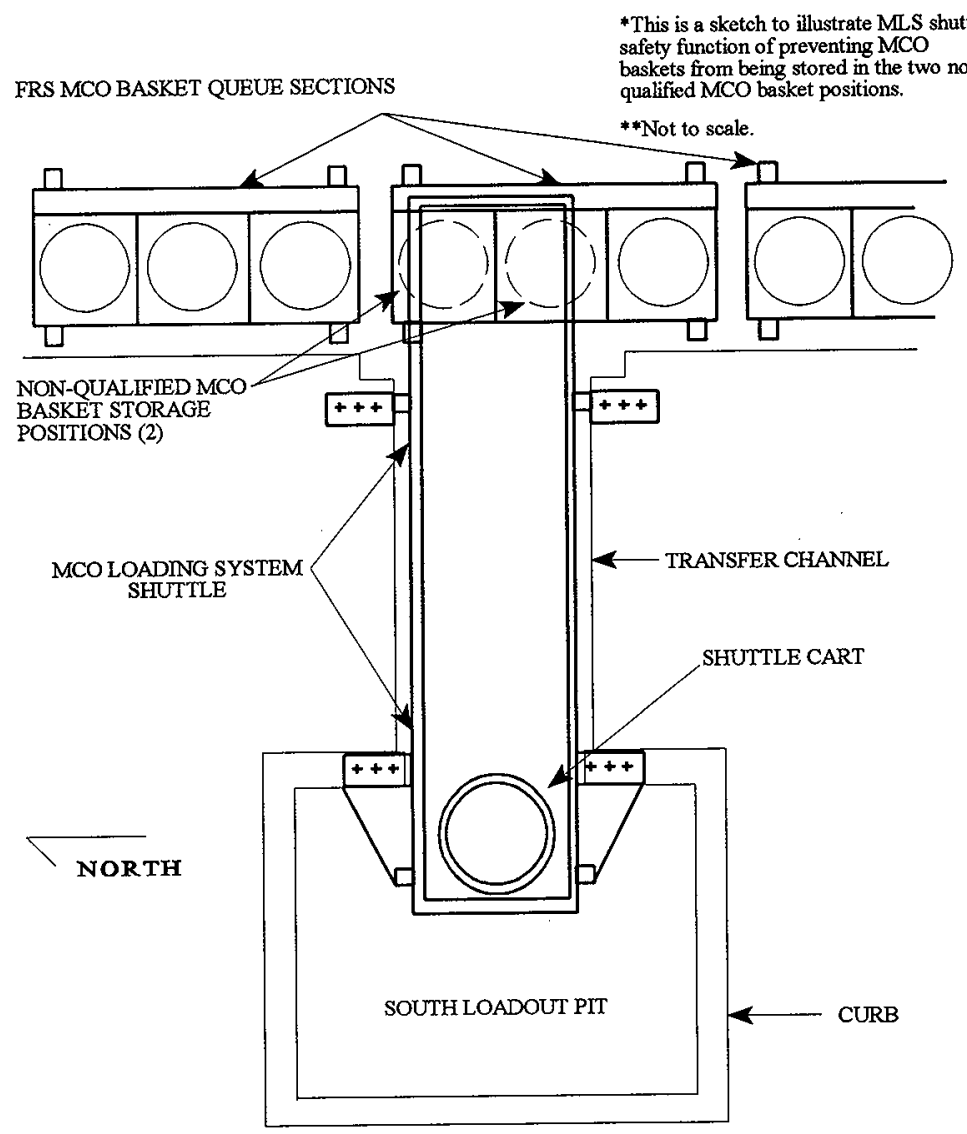


HNF- 2456, Rev. 0

Figure 4-7. MLS Shuttle Conceptual Design Modification.

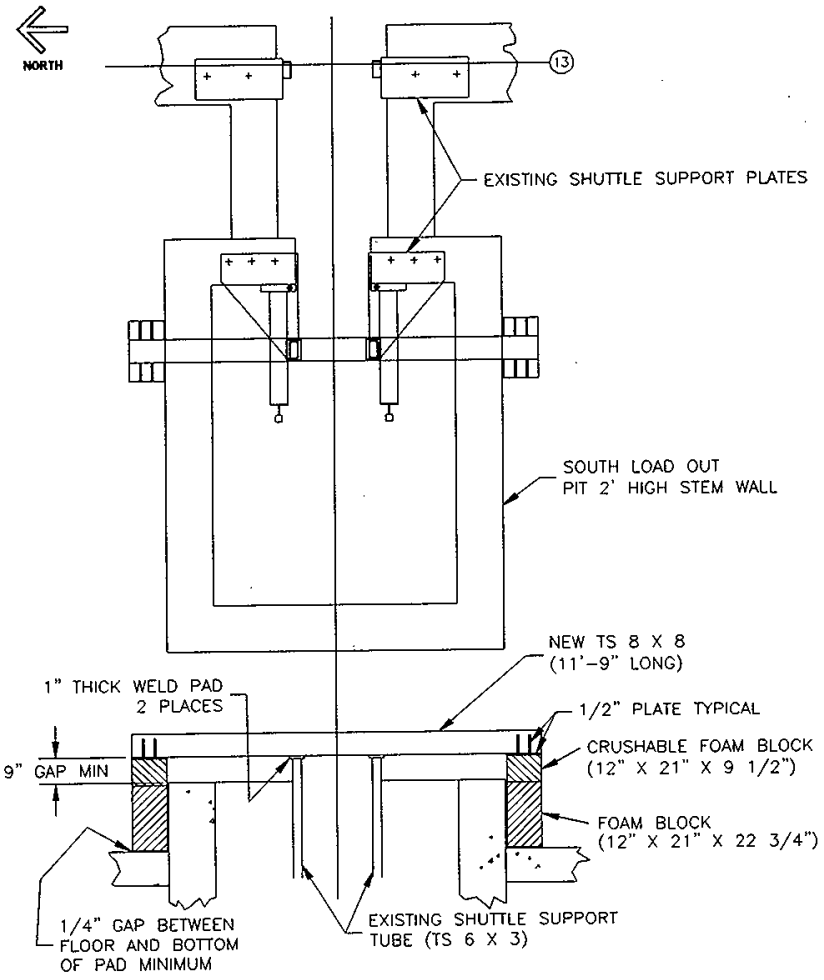


HNF-2456, Rev. 0

This page intentionally left blank. 


\section{APPENDIX 4A SAFETY CLASSIFICATION CRITERIA}

Safety class determinations in this analysis are made in accordance with the following criteria.

The two safety-class designations are safety class and safety significant. The selection of safety-class and safety-significant structures, systems, and components (SSC) is based primarily on their importance to defense-in-depth. Safety-class SSCs prevent or mitigate releases to the public that would otherwise exceed the offsite radiological risk guideline, or prevent accidental nuclear criticality.

Safety-significant SSCs prevent or mitigate releases of radiological materials to onsite workers and toxic chemicals to the offsite public and onsite workers. This includes barriers that are judged to substantially contribute to defense-in-depth independent of quantitative analysis. The safety-significant classification also applies to general services-designated equipment that plays no significant safety role, but could degrade the safety functions of safety-class or safetysignificant SSCs if not restrained during accidents. This is referred to as a "3 over 1" issue; the "3" referring to the older safety class designation system for safety-class 3 SSCs (equates to general services under current classification system) and the " 1 " referring to the older safetyclass 1 designation (safety-class under current classification system). Safety-significant also describes worker safety SSCs that protect the facility worker from serious injury caused by other than standard industrial hazards (those not controlled by institutional safety programs). Institutional Safety Programs include safety training, radiation protection, environmental protection, as low as reasonably achievable (ALARA) safeguards, emergency planning, operational assurance, industrial safety, fire protection, and industrial hygiene.

Table 4A-1. Safety Structures, Systems, and Components Criteria.

\begin{tabular}{|l|l|l|}
\hline \multicolumn{1}{|c|}{ Safety structures, systems, and components } & SSC designation \\
\hline 1. & Prevent or mitigate offsite public exposure in excess of $500 \mathrm{mrem}$ (5 mSv) EDE. ${ }^{1,2}$ & Safety-class \\
\hline 2. & $\begin{array}{l}\text { Place or maintain an operating process in a safe condition that prevents or mitigates } \\
\text { consequences to the public in excess } 500 \text { mrem EDE. }\end{array}$ & Safety-class \\
\hline 3. & $\begin{array}{l}\text { Monitor the release of radioactive materials to the environment during and after accidents } \\
\text { where the monitor's output initiates Emergency Response Plan actions or operator actions } \\
\text { to place the operating process in a safe condition per criterion 2. }\end{array}$ & Safety-class \\
\hline 4. & $\begin{array}{l}\text { Maintain operating parameters within the TSRs or OSRs that protect the public per criteria } \\
\text { 1 or 2. }\end{array}$ & Safety-class \\
\hline 5. & $\begin{array}{l}\text { Maintain double contingency protection against an accidental nuclear criticality as defined } \\
\text { in WHC-CM-4-29, Nuclear Criticality Safety. }\end{array}$ & Safety-class \\
\hline 6. & $\begin{array}{l}\text { Prevent or mitigate onsite exposure to radiological materials in excess of } 5 \text { rem (50 mSv) } \\
\text { EDE. }{ }^{1,2}\end{array}$ & Safety-significant \\
\hline 7. & $\begin{array}{l}\text { Prevent or mitigate toxic chemical exposure to within the risk guidelines of WHC 1996a, } \\
\text { Chapter 7.0.4 }\end{array}$ & Safety-significant \\
\hline 8. & $\begin{array}{l}\text { Place or maintain an operating process in a safe condition that prevents or mitigates } \\
\text { conseguences that exceed criteria 6 or 7. }\end{array}$ & Safety-significant \\
\hline
\end{tabular}


Table 4A-1. Safety Structures, Systems, and Components Criteria.

\begin{tabular}{|l|l|l|}
\hline \multicolumn{2}{|c|}{ Safety structures, systems, and components } & SSC designation \\
\hline 9. & $\begin{array}{l}\text { Prevent or mitigate exposure in excess of 5 rem EDE or an airborne concentration of toxic } \\
\text { material in excess of the applicable chemical ERPG-2 limit to facility operators who are } \\
\text { relied on to achieve the safe condition of criteria 2 and 8. }\end{array}$ & Safety-significant \\
\hline 10. & $\begin{array}{l}\text { Monitor the release of radioactive and/or hazardous materials to the environment during } \\
\text { and after accidents where the monitor's output initiates Emergency Response Plan actions } \\
\text { or operator actions to place the operating process in a safe condition per criterion 8. }\end{array}$ & Safety-significant \\
\hline 11. & $\begin{array}{l}\text { Maintain operating parameters within the TSRs or OSRs that protect the onsite worker per } \\
\text { criterion 6. }\end{array}$ & Safety-significant \\
\hline 12. & $\begin{array}{l}\text { Provide defense-in-depth prevention or mitigation of an uncontrolled release of radioactive } \\
\text { and/or hazardous material deemed significant. }\end{array}$ & Safety-significant \\
\hline 13. & $\begin{array}{l}\text { Prevent or mitigate an acute fatality to a facility worker or serious injury to a group of } \\
\text { workers, except where the SSCs are controlled through an implemented institutional safety } \\
\text { or radiation protection program. }\end{array}$ & Safety-significant \\
\hline 14. & $\begin{array}{l}\text { Support the safety function of a safety-class SSC. This includes control and monitoring } \\
\text { functions (operating air, electrical power, instrumentation, etc.) }{ }^{3}\end{array}$ & Safety-class \\
\hline 15. & $\begin{array}{l}\text { Support the safety function of a safety-significant SSC. This includes control and } \\
\text { monitoring functions (operating air, electrical power, instrumentation, etc.). } \text { 3.4 }^{4}\end{array}$ & Safety-significant \\
\hline
\end{tabular}

Notes:

'Do not include ingestion as a radiological dose pathway. When the initiating event is an (a) natural phenomena hazard, (b) specific equipment failure, or $\$$ specific failure mode, where the associated frequency is supported by adequate data to make the safety analysis uncertainties small, use the consequence threshold of the radiological risk guidelines of Table 3-1. Consider initiating events with a frequency greater than $10^{-1}$ per year to be planned events and mitigate their consequences to within normal operational limits.

${ }^{2}$ Where a postulated accident can cause multiple system failures, evaluate bounding consequences at a common receptor location. Select safety SSCs and determine residual consequences for the purpose of designating other structures or systems.

${ }^{3}$ SSCs that may prevent the adequate function of safety SSCs through physical interaction (seismic, pipe whip, jet impingement, water damage, environmental changes, etc.) are considered to be safety significant.

"Water treatment systems that use chlorine are considered to pose a risk conmonly accepted by the public, provided that their design is consistent with public water treatment plants. Do not designate such systems as safety-class or safety significant 


\subsection{TECHNICAL SAFETY REQUIREMENTS}

Technical safety requirements (TSR) will be provided with the upgraded $\mathrm{K}$ Basins safety analysis report (SAR) (DESH 1998). Chapters 3 and 4 address candidates for TSRs, but until operations of $\mathrm{K}$ Basin systems and the added subproject systems (i.e., fuel retrieval, cask loadout, and integrated water treatment) can be integrated, specifying actual TSRs is not appropriate.

Chapters 3 and 4 define one new candidate TSRs for the support of cask loadout system (CLS). The candidate TSR, for the IPSS locking pins, is described in Table 5-1. TSRs or administrative controls covering CLS operational requirements to support the transport of the Cask-MCO to the Cold Vacuum Drying Facility and safety requirements for the Cold Vacuum Drying Facility and canister storage building will be derived as the CLS subproject and other subprojects are integrated. These requirements will be presented in the upgrade of the $\mathrm{K}$ Basins SAR (DESH 1998).

Table 5-1. Candidate TSR, IPSS Locking Pins, to Support the CLS.

Limiting Conditions for Operation. All four IPSS locking pins shall be used to support the IP in the top IPSS position during cask removal from the IP.

\section{Actions}

\begin{tabular}{|c|c|c|}
\hline Condition & Required actions & Completion time \\
\hline $\begin{array}{l}\text { A. Fewer than four locking pins } \\
\text { were used to support the IP in } \\
\text { the top IPSS position during } \\
\text { cask removal. }\end{array}$ & $\begin{array}{l}\text { A.1 Properly lock all four } \\
\text { locking pins in place to } \\
\text { support the IP in the } \\
\text { top IPSS position. }\end{array}$ & $\begin{array}{l}\text { Before removing the } \\
\text { transfer bay sling during } \\
\text { cask removal }\end{array}$ \\
\hline
\end{tabular}

\section{Surveillance requirements}

Surveillance

Verify all four IPSS locking pins are used to support the IP in the top IPSS position during cask insertion and removal.

Frequency

Each time the cask is inserted or removed from the IP.

BASIS. The analysis supporting the design basis accident 3.4.2.1, Cask-MCO Drop into the South Loadout Pit, includes the IPSS locking pins to absorb energy in conjunction with the IP and the rest of the IPSS to prevent a perforation of the basin. ${ }^{1}$

${ }^{1}$ Chenault, D. M., 1998, Cask and Pail Drop onto the K Basin Immersion Pail Support Structure Bottom Plate, HNF-1897, Rev. 0, including ECN 645075, DE\&S Hanford, Inc., for Fluor Daniel Hanford, Inc., Richland, Washington.

$\begin{array}{ll}\text { TSR } & =\text { technical safety requirement. } \\ \text { IP } & =\text { immersion pail. } \\ \text { IPSS } & =\text { immersion pail support structure. } \\ \text { MCO } & =\text { multi-canister overpack. }\end{array}$


As of March 1998, the product specification requirements placed on CLS operations by other spent nuclear fuel subproject or facility safety analysis requirements are defined in Table 5-2. The inspection requirements are not driven by CLS operations safety concerns. Changes to the inspection requirements will be implemented as part of the upgrade to the K Basins SAR for authorization of CLS operation. Changes to the inspection requirements are not expected to change the design or the conclusion of acceptable risk for installing or operating the CLS, but they may affect the overall fuel retrieval operation process.

Table 5-2. MCO Product Specification Affecting the Cask Loadout System (Pajunen and Sederburg 1998). (2 sheets)

\begin{tabular}{|c|c|c|}
\hline Product specifications & Requirement & Requirements guidance \\
\hline $\begin{array}{l}\text { Number of baskets of } \\
\text { scrap }\end{array}$ & $\leq 2^{1}$ & Administratively control through procedures. \\
\hline $\begin{array}{l}\text { Position of basket of } \\
\text { scrap }\end{array}$ & $\begin{array}{l}\text { Top basket } \\
\text { position }\end{array}$ & Administratively control through procedures. \\
\hline MCO sealing & $\begin{array}{l}\text { Preclean using a } \\
\text { qualified procedure }\end{array}$ & $\begin{array}{l}\text { MCO seal ring cleanliness is controlled by design } \\
\text { of a basket-loading guide. Cleanliness is } \\
\text { administratively controlled by specifying that the } \\
\text { basket guide must be in place during basket } \\
\text { loading and cleaning the seal area before installing } \\
\text { the shield plug. After the basket guides are } \\
\text { removed, the seal ledge is to be flushed to remove } \\
\text { any particles using a qualified tool and procedure. }\end{array}$ \\
\hline $\begin{array}{l}\text { Cask-MCO package } \\
\text { backfill gas }\end{array}$ & $99.9 \%$ helium & $\begin{array}{l}\text { Helium will be inserted through the shield plug } \\
\text { filter trap before transport to the CVDF. Inerting } \\
\text { will be performed through the cask lid by over- } \\
\text { pressurizing, then bleeding off the Cask-MCO } \\
\text { (the MCO communicates directly with the cask } \\
\text { cavity through an internal MCO HEPA filter). } \\
\text { The Cask-MCO void spaces are inerted with } \\
\text { helium to establish an atmosphere that remains } \\
\text { non-flammable as hydrogen is generated from fuel } \\
\text { corrosion within the MCO. The final gas mixture } \\
\text { will have less than } 10 \text { percent oxygen to preclude } \\
\text { ignition potential. }\end{array}$ \\
\hline Cask-MCO pressure & $\begin{array}{l}2 \text { psig to } 3 \text { psig at } \\
\text { ambient } \\
\text { temperature }\end{array}$ & $\begin{array}{l}\text { To be administratively controlled to less than } \\
3 \text { psig as measured after helium backfill. }\end{array}$ \\
\hline
\end{tabular}


Table 5-2. MCO Product Specification Affecting the Cask Loadout System (Pajunen and Sederburg 1998). (2 sheets)

\begin{tabular}{|c|c|c|}
\hline Product specifications & Requirement & Requirements guidance \\
\hline Cask water fill level & $\begin{array}{l}\text { Within } 4 \text { in. of } \\
\text { bottom of shield } \\
\text { plug (both MCO } \\
\text { and cask) }\end{array}$ & $\begin{array}{l}\text { MCO port number } 3 \text { is not used; therefore, the } \\
\text { water in the MCO will never drain to a level } \\
\text { below the top of the fuel. The cask water level is } \\
\text { dictated by the Cask-MCO seal location. Any } \\
\text { drainage needed to accommodate thermal } \\
\text { expansion is accounted for. }\end{array}$ \\
\hline $\begin{array}{l}\text { Transport between } \\
\mathrm{K} \text { Basins and CVDF }\end{array}$ & $<24$ hours & $\begin{array}{l}\text { This will be administratively controlled to less } \\
\text { than } 24 \text { hours; otherwise mitigative actions must } \\
\text { be taken. (Shipping window begins when the cask } \\
\text { is sealed following inerting and ends when the } \\
\text { cask is vented at the CVDF.) }\end{array}$ \\
\hline
\end{tabular}

${ }^{1} \mathrm{HNF}-2256$, Rev. $1{ }^{2}$ shows that two scrap baskets (loaded in the top and bottom positions) is an acceptable configuration to address thermal concerns.

2Duncan, D. R., 1998, Simulation of Normal and Off-Normal Multi-Canister Overpack Behavior, HNF-2256, Rev. 1, DE\&S Hanford, Inc., Richland, Washington.

CVDF = Cold Vacuum Drying Facility.

HEPA = High-efficiency particulate air.

$\mathrm{MCO} \quad=$ Multi-canister overpack.

The passive safety-class SSCs identified in Chapter 4 represent the design features as defined in DOE Order 5480.22.

\section{REFERENCES}

DESH, 1998, K Basins Safety Analysis Report, WHC-SD-WM-SAR-062, Rev. 3D, DE\&S Hanford, Inc., for Fluor Daniel Hanford, Inc., Richland, Washington.

DOE Order 5480.22, 1992, Technical Safety Requirements, U.S. Department of Energy, Washington, D.C.

Chenault, D. M., 1998, Cask and Pail Drop Onto the K Basin Immersion Pail Support Structure Bottom Plate, HNF-1897, Rev. 0, including ECN 645075, DE\&S Hanford, Inc., for Fluor Daniel Hanford, Inc., Richland, Washington.

Duncan, D. R., 1998, Simulation of Normal and Off-Normal Multi-Canister Overpack Behavior, HNF-2256, Rev. 1, DE\&S Hanford, Inc., for Fluor Daniel Hanford, Inc., Richland, Washington. 
HNF-2456, Rev. 0

Pajunen, A. L., and J. P. Sederburg, 1998, Spent Nuclear Fuel Project Product Specification, HNF-SD-SNF-OCD-001, Rev. 2, SGS Eurisys Services Corporation for Fluor Daniel Hanford, Inc., Richland, Washington. 


\subsection{PREVENTION OF INADVERTENT CRITICALITY}

The criteria used in the criticality program and the engineered and administrative controls to be used for preventing criticality accidents are consistent with those currently defined in Chapter 6 of the K Basins safety analysis report (SAR) (DESH 1998). The cask loadout system (CLS) was reviewed for criticality accidents.

Potential changes to the program required for MCO handling and loading operations will be addressed in the upgraded $\mathrm{K}$ Basins SAR. No changes have been identified to date. The MCO handling and loading criticality-related accidents are described in Appendix $6 \mathrm{~A}$.

\subsection{OVERVIEW OF MCO HANDLING AND LOADING CRITICALITY ANALYSIS}

The MCO loading system (MLS) was evaluated for potential nuclear criticality accidents and found to be safe. This evaluation is documented in the criticality safety evaluation report (Kessler 1998). Two principal criticality limits exist that affect the effective neutron multiplication (or criticality) factor $\left(\mathrm{k}_{\mathrm{eff}}\right)$ :

- All spent nuclear fuel loading operations within the basin and until the MCO basket is loaded into the MCO must maintain the $\mathrm{k}_{\text {eff }}$ less than or equal to 0.98 $\left(\mathrm{k}_{\mathrm{eff}} \leq 0.98\right)$, including allowances for all uncertainties (Rogers 1992). This ensures that the system meets the minimum 2-percent margin of reactivity that has been determined to be satisfactory for these operations.

- After the MCO basket is placed in the MCO, the $\mathrm{k}_{\mathrm{eff}}$ is required to be less than or equal to $0.95\left(\mathrm{k}_{\text {eff }} \leq 0.95\right)$, including allowances for all uncertainties. This means that the system has at least a 5-percent margin of reactivity. $\mathrm{A} \mathrm{K}_{\text {eff }} \leq 0.95$ is a U.S. Nuclear Regulatory Commission requirement for new facilities (Garvin 1997).

The criticality safety evaluation looked at the following accidents:

- Spills of loaded MCO baskets into the basin and into a partially loaded MCO

- Drop accidents involving loaded, flooded, sealed MCOs during removal from the load-out pit

- Misloaded MCO baskets and MCOs.

MLS spill accidents are the same as those identified for the fuel retrieval subproject (Kessler and Peck 1998). 
HNF-2456, Rev. 0

\subsubsection{Summary of Conservatism}

The MCO handling and loading criticality analysis includes the following conservative assumptions:

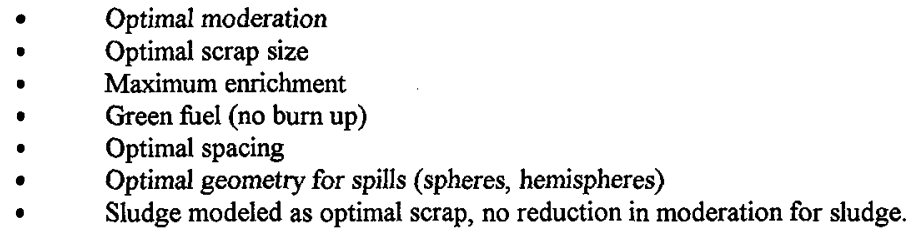

\subsubsection{Summary of Conclusions}

Conservative assumptions were made for determining "worst case" normal and accident conditions. The analysis shows that the double contingency principle is met (i.e., at least two unlikely, independent, and concurrent changes in process conditions are necessary before a criticality accident is possible). The analysis did not establish any need for safety-class equipment. (Safety-class equipment [e.g., basket size and MCO configuration] required to prevent criticality accidents as identified by the fuel retrieval system and SNF processing and storage facilities criticality specification evaluation reports [CSER] [Kessler and Peck 1998 and Schwinkendorf 1997]). However, the analysis did establish a need for controlled limits for handling and loading filled MCO baskets.

\subsubsection{Mass Limits}

Mass limits for the MCO scrap baskets are specified in the fuel retrieval subproject CSER (Kessler and Peck 1998). Mass in the MCO fuel assembly baskets is limited by design. Before moving loaded baskets from the fuel retrieval system table to the storage queue, the baskets are weighed to verify compliance with the limits of the fuel retrieval CSER (Kessler and Peck 1998).

\subsubsection{Summary of Controls}

The criticality safety analysis (Kessler 1998) determined that operational controls were needed to ensure criticality safety and satisfy the double contingency criterion. These controls are summarized as follows.

- Limit 1. A maximum of two baskets of scrap may be loaded into an MCO, one in the top tier and one in the bottom tier. 
- Limit 2. The layer of fissionable material between the FRS MCO basket queue and MCO where a basket spill can occur shall not exceed 1.5 in. thick while handling Mark IA fuel or 5 in. thick while handling Mark IV fuel.

- Limit 3. Any MCO basket containing fissile material that is handled outside controlled storage must be kept at least $15 \mathrm{ft}$ from other MCO baskets that contain fissile material and are located outside controlled storage.

\subsubsection{Dimensions Requiring Quality Control Verification}

The installation of the MLS shuttle over the FRS MCO basket queue requires verification that it is not physically possible for MCO baskets to be loaded into the two positions in the fuel retrieval system queue that are directly adjacent to the transfer channel.

\subsection{REFERENCES}

DESH, 1998, K Basins Safety Analysis Report, WHC-SD-WM-SAR-062, Rev. 3D, DE\&S Hanford, Inc. for Fluor Daniel Hanford, Inc., Richland, Washington.

Kessler, S. F., 1998, Criticality Safety Evaluation Report for Multi-Canister Overpack Loading and Handling at the $K$ Basins, HNF-2151, Rev. 0, Fluor Daniel Northwest Services, Inc., for Fluor Daniel Hanford, Inc., Richland, Washington.

Kessler, S. F., and S. H. Peck, 1998, Criticality Safety Evaluation Report for the K Basin Fuel Retrieval Subproject, HNF-SD-SNF-CSER-010, Rev. 0, Fluor Daniel Northwest, Inc. for Fluor Daniel Hanford, Inc., Richland, Washington.

Garvin, L. J., 1997, Spent Nuclear Fuel Project Path Forward, Additional NRC Requirements, HNF-SD-SNF-DB-003, Rev. 3, Fluor Daniel Hanford, Inc., Richland, Washington.

Rogers, C. A., 1992, Use of a $k_{e f f}$ Subcritical Limit of 0.98, WHC-SD-SQA-CSA-20330, Rev. 0, Westinghouse Hanford Company, Richland, Washington.

Schwinkendorf, K. N., 1997, Criticality Safety Evaluation Report for Spent Nuclear Fuel Processing and Storage Facilities, HNF-SD-SNF-CSER-005, Rev. 3, Fluor Daniel Hanford, Inc., Richland, Washington. 
HNF-2456, Rev. 0

This page intentionally left blank. 
HNF-2456, Rev. 0

\section{APPENDIX 6A}

MCO LOADING SYSTEM CRITICALITY-RELATED ACCIDENTS/ANALYSIS 
HNF-2456, Rev. 0

This page left intentionally blank. 
HNF-2456, Rev. 0

\section{APPENDIX 6A}

\section{MCO LOADING SYSTEM CRITICALITY RELATED ACCIDENTS/ANALYSIS}

\section{A.1 INTRODUCTION}

The criticality analysis associated with the multi-canister overpack (MCO) loading system (MLS) equipment normal and off-normal loading conditions is summarized in the following paragraphs. The MLS was evaluated for potential nuclear criticality accidents and found to be safe. This evaluation is documented in the criticality safety evaluation report (Kessler 1998).

Two principal criticality limits exist that affect the effective neutron multiplication (or criticality) factor $\left(\mathrm{k}_{\mathrm{eff}}\right)$ :

- All spent nuclear fuel loading operations within the basin and until the MCO basket is loaded into the MCO must maintain the $\mathrm{k}_{\text {eff }}$ less than or equal to 0.98 ( $k_{\text {eff }} \leq 0.98$ ), including allowances for all uncertainties (Rogers 1992). This ensures that the system meets the minimum 2-percent margin of reactivity that has been determined to be satisfactory for these operations.

- After the MCO basket is placed in the $\mathrm{MCO}$, the $\mathrm{k}_{\text {eff }}$ is required to be less than or equal to $0.95\left(\mathrm{k}_{\text {eff }} \leq 0.95\right)$, including allowances for all uncertainties. This means that the system has at least a 5-percent margin of reactivity. $\mathrm{AK}_{\text {eff }} \leq 0.95$ is a U.S. Nuclear Regulatory Commission requirement for new facilities (Garvin 1997).

The criticality safety evaluation looked at the following forms of fissionable material:

- Assemblies that include both inner and outer elements in the tube-in-tube configuration.

- Elements that are inners or outers and are separate.

- Scrap fuel pieces too small to be manipulated with tongs or too small to be packaged with the associated fuel assemblies or elements.

- Sludge, which is oxidized uranium and metallic fuel fragments resulting from damaged fuel that has accumulated in canisters or on the basin floor, transfer channel floor, or south loadout pit floor. Sludge was modeled as optimized scrap.

The criticality analysis supporting the MCO loading and handling fuel configurations is based on calculations assuming unirradiated fuel of the highest authorized enrichment in the normal storage arrangements and postulated accident conditions. The assumption of unexposed optimally configured Mark IA fuel in these calculations is the most conservative and most limiting basis for the calculations from a standpoint of nuclear criticality safety. 
The equipment used for MCO loading and handling operations is described in Chapter 2.0. The following engineered control provides criticality safety by limiting improper fissile material placement. The MCO loading system shuttle must be installed over the fuel retrieval system queue in a way that physically prevents MCO baskets from being inserted into the queue storage locations directly adjacent to the transfer channel.

The administrative controls to be applied to the MCO loading and handling operations are specified as limits in Section 6A.3.1. These limits will be imposed by the $\mathrm{K}$ Basin criticality prevention specifications (CPS).

The prevention of accidental formation of critical masses in the MCO loading system equipment is based primarily on limiting the fuel mass and confining the fuel in a critically safe geometry. The control is based on the double-contingency criterion-at least two unlikely, independent, and concurrent changes (contingencies) in processing or operating conditions must happen before a criticality accident is possible. No single contingency shall result in a criticality.

No engineered safety features or controls are provided to prevent misloading of the fuel baskets (e.g., Mark IA fuel loaded in Mark IV baskets). The administrative controls identified in the fuel retrieval subproject CSER will be incorporated into the K Basins CPS and are assumed to prevent such an occurrence. The defined single-contingency loads are acceptable. Hypothetical failure of the controls is postulated to ensure criticality safety.

A series of scenarios associated with the MCO loading and handling operations with a potential for accidental criticality were evaluated in the criticality safety analysis associated with the MCO loading (Kessler 1998). In all instances, the double-contingency criterion is met. Additional beyond extremely unlikely single-contingency accidents were analyzed. All scenarios, both normal and off-normal, were analyzed for criticality safety, and are listed in Section 6A.2. Contingency analyses also were performed on each scenario and are described in Section 6A.3.

\section{A.2 CRITICALITY-RELATED ACCIDENT SCENARIOS}

\section{A.2.1 Mark 1A MCO Loading}

- Normal Condition: Mark IA MCO with four fuel assembly and two scrap baskets, one on each end.

- Off-Normal Condition:

- Scrap baskets loaded in wrong positions

- Scrap basket limit exceeded

- Fuel basket spill on the south loadout pit or basin floor, along a wall, or in a corner 
HNF-2456, Rev. 0

- Scrap basket spill on the south loadout pit or basin floor, along a wall, or in a corner.

6A.2.2 Mark IV MCO Loading

- Normal Condition: Mark IV MCO with three fuel assembly and two scrap baskets, one on each end.

- Off-Normal Condition:

- Scrap baskets loaded in wrong positions

- Scrap basket limit exceeded

- Mark IA fuel misloaded into Mark IV basket

- Mark IA scrap misloaded into Mark IV scrap basket

- Fuel basket spill on the south loadout pit, the basin floor, along a wall, or in a corner

- Scrap basket spill on the south loadout pit, the basin floor, along a wall, or in a corner.

6A.2.3 MCO Lifted to Surface of Basin

Normal Condition: MCO loaded, shield plug installed, locking and lifting ring not installed.

- Off-Normal Condition: MCO dropped in vertical position.

6A.2.4 MCO Transferred to Transport Vehicle

- Normal Condition: MCO loaded, cask lid installed.

- Off-Normal Condition:

- MCO dropped and lands in vertical position

- MCO dropped and lands in a horizontal position. 
HNF-2456, Rev. 0

\section{A.2.5 Single-Pass Reactor Fuel Loaded in the MCO}

- Normal Condition: MCO loaded, cask lid installed.

- Off-Normal Condition: MCO dropped in vertical position.

\section{A.3 CONTINGENCY ANALYSIS}

Section 6A.2 describes the off-normal conditions evaluated by the CSER (Kessler 1998). An off-normal condition identified may realistically involve many variations and degrees of consequences in an actual situation. A limiting case, or set of cases identifies the most limiting consequence of each off-normal condition category.

\section{A.3.1 Potential Error or Failure Situations}

A criticality safety evaluation includes analyzing contingencies that decrease the conservatism of the results. The specific conditions, the model assumptions, and the reactivity consequences evaluation are included in the criticality analysis:

- Equipment dimension variation caused by the following:

- Mechanical disarrangement (e.g., earthquake)

- Effects from accidental pressurization.

Comment. The MCO loading equipment has been analyzed for mechanical disarrangement caused by seismic events and heavy load drops. No safety-class design features are required to preclude a criticality. The transfer shuttle is designed to withstand an earthquake, though not enough fissile material is present for a criticality to occur if a single basket is dropped and falls, causing a spill, providing limit 2 has been complied with (Kessler and Peck 1998). This spill will be cleaned up before resuming operations.

- Excesses in mass or volume from errors in the following:

- Segregating materials from different enrichments

- Over-batching

- Analysis error.

Comment. WHC-SD-SNF-CSER-003, K Basins Consolidated Fuel Storage and Handling Criticality Safety Evaluation (Jensen 1996), and K Basins Process Standard 304, "Criticality Prevention Specification" (DESH 1996), define requirements for segregating materials, in particular for ensuring the Mark IA and other more highly enriched fuel are loaded only into Mark IA baskets. 
- Excess of mass in a non-safe geometry vessel resulting from the following

- Cross connection

- Unauthorized piping changes.

Comment. The MCO and the fuel and scrap baskets have been evaluated to ensure that excess mass will not lead to inadvertent criticality. Limit 3 allows only one fuel or scrap basket to be out of storage at any time. In all cases, limits and the need for multiple contingencies to occur provide adequate safety margin. Because no chemical processing occurs, cross connections and unauthorized piping changes should not be a problem.

- Changes in geometry resulting from the following:

- Spilling or leakage

- Mechanical compacting.

Comment. The MCO loading equipment was evaluated to identify areas where spills of fuel or mechanical compacting or settling could occur. Geometry controls and limitations on spills minimize occurrences from these sources. Limit 2 ensures that mass is controlled to prevent criticality in case of spills.

- Changes in reflection from the following:

- Flooding

- Addition of shielding (dose reduction campaign).

Comment. All MCO loading activities occur underwater and were analyzed assuming optimal moderating conditions. Changes in reflection caused by a spill on concrete were analyzed. A shield plug is inserted into the loaded MCO before any movement and was assumed to be installed for all analyses (Schwinkendorf 1997).

- Changes in concentration from the following:
- Precipitation
- Accumulation
- Evaporation.

Comment. Because no chemical change of state occurs and minimal changes in physical form occur (a small amount of fuel may corrode during loading and movement to the Cold Vacuum Drying Facility), these items are not a concern.

- Increased interaction from the following:

- Material in transit 


\section{- Spacing error.}

Comment. Existing controls and new limits provide suitable control over transit of materials during MCO loading operations. Spacing errors are minimized by physical constraints and controls and by easily monitored limits (limit 3 ).

- Changes in moderation from the following:

\section{- Condensation \\ - Evaporation.}

Comment. All MCO loading operations are conducted in the basin water and were analyzed with assumptions of fully moderated and optimized conditions. Removal of the MCO from the basin will not increase moderation and subsequent removal of the water will reduce $k_{\text {eff }}$.

\section{A.3.2 Scrap Basket Spills into a Partially Loaded MCO}

Scrap basket spill accidents during loading of the MCO were analyzed for the MCO loading and handling CSER. These accidents were for the cases in which fuel scrap is spilled into the MCO during loading. The most limiting accident was the one in which the final scrap basket was spilled onto the fuel baskets and the bottom scrap basket, which was already loaded in the MCO. The accident analysis included spilling fuel scrap down the center 6-in. schedule XXS pipe in the Mark IA baskets and the 2-in. pipe in the Mark IV baskets. The $k_{\text {eff }}$ values resulting from these accident analyses were determined to be within acceptable limits. The following cases were examined:

- Mark IA Scrap Basket Spill into a Mark IA-filled MCO

- Mark IV Scrap Basket Spill into a Mark IV-filled MCO.

Results from both analyses satisfied the criticality safety criterion (Kessler 1998).

\section{A.4 MCO LOADING SYSTEM OPERATIONAL LIMITS}

The criticality safety evaluation report (CSER) (Kessler 1998) analysis must demonstrate that the allowed fuel configuration and any credible single-contingency accident conditions will not exceed the $\mathrm{k}_{\text {tinit }}$. The analysis, described in HNF-2151, Criticality Safety Evaluation Report for the Multi-Canister Overpack Loading and Handling at the K Basins (Kessler 1998), concludes that having unacceptable fuel configurations is impossible under single-contingency conditions because of the use of engineered safety features, mass limits for the MCO baskets (enforced by the fuel retrieval system), and other operational limits.

The CSER establishes a number of limits either to address unacceptable accident conditions or to enforce assumptions of the analyses. These limits are required to be followed so that all 
normal and off-normal conditions will satisfy the double contingency criterion and that the MCO loaded with fissile material from the $\mathrm{K}$ Basins will meet the acceptance criteria. The limits will be imposed on the facility through criticality prevention specifications (CPS).

This section describes the limits imposed to ensure criticality safety for each stage of the MCO loading and handling operations. Each limit is numbered and the bases for the limits are provided below the limit. The bases also include information regarding implementation methods associated with the limit, including design features, engineered safety features, mass controls, and administrative controls. Additional information is available in the CSER (Kessler 1998) section covering the specific analysis for each operation.

\section{A.4.1 Limits}

Limit 1. A maximum of two baskets of scrap may be loaded into an $\mathrm{MCO}$, one in the top tier and one in the bottom tier only.

Basis. Scrap has been modeled as optimally sized rods at optimal water moderation. Placing scrap at both ends of the stack of baskets in the MCO limits the $k_{\text {eff }}$ to less than 0.95 for all credible accidents.

This limit is based on analyses for HNF-SD-SNF-CSER-005, Criticality Safety Evaluation Report for Spent Nuclear Fuel Processing and Storage Facilities (Schwinkendorf 1997), which has a $\mathrm{k}_{\text {timit }}$ of 0.95 . The limit will be implemented by administrative controls for loading one scrap basket in the top tier of an MCO. This limit also ensures compliance with the limits for Cold Vacuum Drying Facility and CSB operations.

Justification for the Use of Administrative Controls. Designing an automatic loading system that could discriminate between fuel and scrap baskets is not practicable. The only practicable solution is to use administrative controls.

Limit 2. The layer of fissionable material between the FRS MCO basket queue and MCO where a basket spill can occur shall not exceed a thickness of 1.5 in. while handling Mark IA fuel or 5 in. while handling Mark IV fuel.

Basis. The analyses in HNF-SD-SNF-CSER-010 (Kessler and Peck 1998) of potential basket spill accidents onto the floor during MCO basket loading have allowed contamination of the floor with fissionable materials and established a floor sludge limit of 1.5 in. while handling Mark IA fuel and 5 in. while handling Mark IV fuel.

This limit is implemented by administrative controls on the allowable sludge buildup using measuring or depth-indicating devices.

Justification for Use of Administrative Controls. Engineered features to implement or eliminate this limit cannot be provided practically. The limits on mass for scrap baskets and the conservative assumptions associated with the composition of the scrap provide reasonable 
protection. The controls are simple to administer and consistent for both basins. Implementation using administrative controls does not present a significant challenge to criticality safety and is judged to be reasonable, especially considering the conservatism in the criticality analysis. A single limit could be defined for both basins, but this would require a significant sludge cleanup effort in $\mathrm{K}$ East Basin, which is not considered to be practical.

Limit 3. Any MCO basket containing fissile material that is handled outside controlled storage must be kept at least $15 \mathrm{ft}$ from other MCO baskets that contain fissile material and are located outside controlled storage.

Basis. Movement of two MCO scrap baskets at the same time could result in the MCO baskets spilling fuel in the same area as the result of a drop accident or seismic event. This spill could exceed the criticality limit. Moving multiple scrap baskets at the same time in the same area is not necessary. Therefore, only one MCO basket containing fissile material out of controlled storage can be located within $15 \mathrm{ft}$ of another MCO basket containing fissile material that is out of controlled at a time. This should not present any operational problems because only a few MCO basket moves are required.

Controlled storage means the MCO basket is located in one of the three table positions or in the queue where the basket is surrounded by an MCO basket confinement pipe, or in the MCO. The limit assumes that an MCO basket on the transfer shuttle is out of "controlled storage." This limit also assumes that the MCO loading equipment will use the fuel retrieval system's MCO basket grapple to move MCO baskets to the loading system shuttle at the load-out pit entrance and that MCO loading equipment will not be able to traverse into the basin. If multiple MCO basket grapples are available, other grapples will be controlled by locking them out of service to ensure that the limit will not be exceeded. This limit is based on HNF-SD-SNF-CSER-010, "MCO Basket Movement Accident 2" (Kessler and Peck 1998).

The limit will be implemented by design features (only one MCO basket grapple) or administrative controls (control the number of baskets out of controlled storage and ensure that spare grapples are locked out of service).

Justification for use of administrative controls. Because of the design of the MCO loading equipment and the fuel retrieval equipment, implementing this limit by engineered features alone is not practical. Limits on the number of canisters that can be in transit have been successfully used. The analysis and limits on mass for scrap baskets and the conservative assumptions associated with the composition of the scrap provide additional protection. The controls are simple to administer and consistent for both basins. Implementation using administrative controls does not present a significant challenge to criticality safety and is judged to be reasonable, especially considering the conservatism in the criticality analysis. 


\section{A.4.2 Dimensions Requiring Quality Control Verification}

The installation of the MLS shuttle over the queue requires verification that loading MCO baskets into the two positions in the fuel retrieval system queue directly adjacent to the transfer channel is not physically possible.

\section{A.5 REFERENCES}

Garvin, L. J., 1997, Spent Nuclear Fuel Project Path Forward, Additional NRC Requirements, HNF-SD-SNF-DB-003, Rev. 3, Fluor Daniel Hanford, Inc., Richland, Washington.

Kessler, S. N., 1998, Criticality Safety Evaluation Report for Multi-Canister Overpack Loading and Handling at the K Basins, HNF-2151, Rev. 0, Fluor Daniel Northwest, Inc. For Fluor Daniel Hanford, Inc., Richland, Washington.

Kessler, S. N., and S. H. Peck, 1998, Criticality Safety Evaluation Report for the K Basin Fuel Retrieval Subproject, HNF-SD-SNF-CSER-010, Rev. 0, Fluor Daniel Northwest, Inc. for Fluor Daniel Hanford, Inc., Richland, Washington.

Rogers, C. A., 1992, Use of a $k_{e f f}$ Subcritical Limit of 0.98, WHC-SD-SEA-C.S.A.-20330, Rev. 0, Westinghouse Hanford Company, Richland, Washington.

Schwinkendorf, K. N., 1997, Criticality Safety Evaluation Report for Spent Nuclear Fuel Processing and Storage Facilities, HNF-SD-SNF-CSER-005, Rev. 3, Fluor Daniel Hanford, Inc., Richland, Washington. 
HNF-2456, Rev. 0

This page intentionally left blank. 


\subsection{RADIATION PROTECTION}

The existing K Basin Radiation Protection Program described in the K Basins safety analysis report (SAR) (DESH 1998) applies to the cask loading system (CLS) equipment installation and installation acceptance testing. Potential revisions to the existing program as a result of the CLS operations will be evaluated as part of the $\mathrm{K}$ Basins SAR upgrade activities. No changes have been identified that will result in a revision to the existing $K$ Basins radioactive protection program at this time.

As part of the engineering evaluation of the CLS equipment design, an as-low-as-reasonablyachievable (ALARA) assessment was performed to review the adequacy of the CLS design features used to protect personnel from radiological exposure during operational activities (Brisbin 1997a, Hillesland 1997). The assessment considered exposure to workers mostly from operation activities associated with the CLS equipment. The CLS is deemed to have no significant maintenance requirements (Brisbin 1997a, Brisbin 1997b, Kee 1997). Based on the results of the estimated exposures, the design was evaluated to see if design or operating improvements could be made to reduce worker dose. Another ALARA assessment was performed to support the installation activities (Parker 1998). Detailed ALARA assessments supporting the MCO cask and MCO are identified in their associated safety analyses (Edwards 1998, Lorenz 1997).

MCO baskets are loaded underwater. Only CLS tools and equipment that penetrate the basin water, such as the MLS gantry extending mast and grapple, cask load slings, MCO shield plug tool, and immersion pail lid, will expose contamination (from the basin water) to the air.

The design features that minimize worker dose were identified as maintaining a minimum water cover over all CLS equipment and fuel-handling activities; using a remotely operated, semiautomatic MCO loading system to minimize operator time in the basin; using permanently installed shielding (i.e., south loadout pit curb) and temporary shielding to minimize the dose during operations; and following standard $\mathrm{K}$ Basins radiation protection practices.

The standard K Basins radiation protection practices include the use of quick- disconnect hardware and design features that facilitate decontamination efforts and administrative controls. The administrative controls that minimize dose include scheduling in-basin workers on rotating shifts and applying standard ALARA principles to minimize time in the basin. The ALARA principles include moving workers to a low-dose area when work tasks do not require them to be in high-dose areas and using a maintenance approach that minimizes repair of low-cost replaceable components.

No changes to this section of the $\mathrm{K}$ Basins safety analysis report are associated with the CLS. 
HNF-2456, Rev. 0

\section{REFERENCES}

Brisbin, S. A, 1997a, Design Review Report for the Hanford K East and K West Basins MCO Loading System, HNF-SD-SNF-DR-004, Rev. 1, DE\&S Hanford, Inc., for Fluor Daniel Hanford, Inc., Richland, Washington.

Brisbin, S. A., 1997b, Design Analysis Report for the TN-WHC Cask and Transportation System, HNF-SD-SNF-FDR-003, DE\&S Hanford, Inc., for Fluor Daniel Hanford, Inc., Richland, Washington.

DESH, 1998, K Basins Safety Analysis Report, WHC-SD-WM-SAR-062, Rev. 3D, DE\&S Hanford, Inc., for Fluor Daniel Hanford, Inc., Richland, Washington.

Edwards, W. S., 1998, Safety Analysis Report for Packaging (Onsite) Multi-canister Overpack Cask, HNF-SD-TP-SARP-017, Rev. 1, draft, Waste Management Federal Services Inc., Northwest Division, for Fluor Daniel Hanford, Inc., Richland, Washington.

Hillesland, K. E., 1997, MCO Shield Plug Dose Rate Analysis, HNF-SD-SNF-CN-026, Rev. 0, Fluor Daniel Northwest Services, Inc., for DE\&S Hanford, Inc., for Fluor Daniel Hanford, Inc., Richland, Washington.

Kee, A. T., 1997, TN-WHC Cask and Transportation System Installation, Operations, Repair, and Maintenance (TORM), HNF-SD-SNF-OMM-003, Rev. 0, DE\&S Hanford Inc., Richland, Washington.

Lorenz, B. D., 1997, Multicanister Overpack Topical Report, HNF-SD-SNF-SARR-005, Rev. 1, draft, Fluor Daniel Hanford, Inc., Richland, Washington.

Parker, B. M., 1998, ALARA Review of work package 1K-97-03553, Install Multiple Canister Overpack Loading System Components, white paper approved by J. Kurtz, B. Parker, R. Gant, DE\&S Hanford, Inc., Richland, Washington. 


\subsection{HAZARDOUS MATERIAL PROTECTION}

The existing Hazardous Material Protection Program is described in the current $\mathrm{K}$ Basins safety analysis report (DESH 1998) and will be applied to cask loading system (CLS) installation and installation testing. Potential changes to the Hazardous Material Protection Program will be evaluated and addressed in the upgraded $\mathrm{K}$ Basins safety analysis report. No potential changes have been identified as part of the ongoing CLS activities.

\section{REFERENCE}

DESH, 1998, K Basins Safety Analysis Report, WHC-SD-WM-SAR-062, Rev. 3D, DE\&S Hanford, Inc., for Fluor Daniel Hanford, Inc., Richland, Washington. 
HNF-2456, Rev. 0

This page intentionally left blank. 
HNF-2456, Rev. 0

\subsection{RADIOACTIVE AND HAZARDOUS WASTE MANAGEMENT}

The cask loading system (CLS) installation and installation acceptance testing will adhere to the requirements of the existing $\mathrm{K}$ Basins Radioactive and Hazardous Waste Management Program as described in the current K Basins safety analysis report (DESH 1998). Potential changes to the program based on CLS operation will be evaluated and addressed in the upgraded $\mathrm{K}$ Basins safety analysis report. No changes have been identified to date.

\section{REFERENCE}

DESH, 1998, K Basins Safety Analysis Report, WHC-SD-WM-SAR-062, Rev, 3D, DE\&S Hanford, Inc., for Fluor Daniel Hanford, Inc., Richland, Washington. 
HNF-2456, Rev. 0

This page intentionally left blank. 


\subsection{INITIAL TESTING, IN-SERVICE SURVEILLANCE, AND MAINTENANCE}

The provisions for initial testing, in-service surveillance, and maintenance program as described in the K Basins safety analysis report (DESH 1998) will be applied, as appropriate, to the cask loadout system (CLS) equipment. Three types of testing will be done before startup of the CLS. They are factory acceptance testing, construction acceptance testing, and preoperational acceptance testing. The factory acceptance test will demonstrate to the satisfaction of the project design authority that the designed equipment can perform its intended function during all expected operations. The major pieces of designed equipment include the immersion pail support structure, the immersion pail, the the multi-canister overpack loading system (MLS) shuttle, the MLS control and monitoring system, and the MLS gantry and gantry support structure. The construction acceptance test will demonstrate that the installation matches the design and that all equipment is functional. The preoperational acceptance test will demonstrate that the design and installation are operable and the equipment can perform its intended functions. Initial system testing, in-service surveillance, and maintenance will be addressed in the upgraded K Basins safety analysis report (DESH 1998).

\section{REFERENCE}

DESH, 1998, K Basins Safety Analysis Report, WHC-SD-WM-SAR-062, Rev. 3D, DE\&S Hanford, Inc., for Fluor Daniel Hanford, Inc., Richland, Washington. 
HNF-2456, Rev. 0

This page intentionally left blank. 


\subsection{OPERATIONAL SAFETY}

The existing operational safety program provisions, described in the current $\mathrm{K}$ Basins safety analysis report (DESH 1998) will be applied to the cask loadout system (CLS) equipment. Fire hazards to the worker are being addressed in a revision of the fire hazards analysis (FHA) (Myott 1998). A list of CLS combustibles consisting of the windbreak structure, the cask transport tires, engine oil, and diesel fuel was provided to the cognizant engineer for incorporation into the next revision of the FHA. The CLS will not affect the conclusions of the draft FHA. Potential changes to the program based on CLS operation will be evaluated and addressed in the upgraded K Basins safety analysis report (Myott 1998). No changes have been identified to date.

\section{REFERENCES}

DESH, 1998, $K$ Basins Safety Analysis Report, WHC-SD-WM-SAR-062, Rev. 3D, DE\&S

Hanford, Inc., for Fluor Daniel Hanford, Inc., Richland, Washington.

Myott, C. F., 1998, Fire Hazards Analysis for the K Basins Facilities at $100 \mathrm{~K}$ Area, HNF-SD-SNF-FHA-001, Rev. 1, draft, DE\&S Hanford, Inc., for Fluor Daniel Hanford, Inc., Richland, Washington. 
HNF-2456, Rev. 0

This page intentionally left blank. 


\subsection{PROCEDURES AND TRANNING}

All cask loadout system (CLS) installation and installation testing activities will be performed in accordance with written procedures. Procedures will be developed and maintained in accordance with the program described in the K Basins safety analysis report (DESH 1998). Personnel performing CLS installation and installation testing will be trained and qualified for the tasks they are performing. Revisions to the procedure and training program necessary to support operation of the CLS will be described in the updated K Basins safety analysis report.

\section{REFERENCE}

DESH, 1998, K Basins Safety Analysis Report, WHC-SD-WM-SAR-062, Rev. 3D, DE\&S Hanford, Inc., for Fluor Daniel Hanford, Inc., Richland, Washington. 
HNF-2456, Rev. 0

This page intentionally left blank. 


\subsection{HUMAN FACTORS}

No human factors apply to the cask loadout system (CLS) safety-class structures, systems, and components (SSC) because all CLS safety-class SSCs are passive devices. However, human factors considerations, as described in the current K Basins safety analysis report (DESH 1998), were applied while designing CLS equipment to ensure that any human-machine interfaces, such as the multi-canister overpack loading system control panel, are operationally and ergonomically sound. Potential changes will be evaluated and addressed in the upgraded $\mathrm{K}$ Basins safety analysis report. No changes have been identified to date.

\section{REFERENCE}

DESH, 1998, K Basins Safety Analysis Report, WHC-SD-WM-SAR-062, Rev. 3D, DE\&S Hanford, Inc., for Fluor Daniel Hanford, Inc., Richland, Washington. 
HNF-2456, Rev. 0

This page intentionally left blank. 
HNF-2456, Rev. 0

\subsection{QUALITY ASSURANCE}

Cask loadout system (CLS) installation and installation testing will be performed in compliance with the existing Fluor Daniel Northwest Quality Assurance Program (FDNW Practice 134.000.1100, Quality Management Program) and DOE 830.12D, Quality Assurance Requirements for Nuclear Facilities. The program required for CLS operation will be addressed in the upgraded $\mathrm{K}$ Basins safety analysis report. No changes have been identified to date.

\section{REFERENCES}

DOE 830.12D, Quality Assurance Requirements for Nuclear Facilities, U.S. Department of Energy, Washington, D.C.

FDNW 134.000.1100, Quality Management Program, Fluor Daniel Northwest Services, Inc., Richland, Washington. 
HNF-2456, Rev. 0

This page intentionally left blank. 
HNF-2456, Rev. 0

\subsection{EMERGENCY PREPAREDNESS PROGRAM}

The existing $\mathrm{K}$ Basin emergency preparedness program, as described in the current $\mathrm{K}$ Basins safety analysis report (DESH 1998), will be applied during installation and installation testing of the cask loadout system (CLS). The program will be evaluated regarding CLS operation and will be addressed in the upgraded K Basin safety analysis report (DESH 1998). No changes have been identified to date.

\section{REFERENCE}

DESH, 1998, K Basins Safety Analysis Report, WHC-SD-WM-SAR-062, Rev. 3D, DE\&S Hanford, Inc., for Fluor Daniel Hanford, Inc., Richland, Washington. 
HNF-2456, Rev. 0

This page intentionally left blank. 
HNF-2456, Rev. 0

\subsection{PROVISIONS FOR DECONTAMINATION AND DECOMMISSIONING}

The decontamination and decommissioning of the equipment were considered in the cask loadout system (CLS) design. Decontamination and decommissioning concerns addressed in the CLS equipment design included the following:

- $\quad$ Fabricate components that will be used underwater in parts and from materials amenable to decontamination.

- $\quad$ Provide access for cleaning process piping.

- Specify that waterproof materials be used for fabricating equipment.

- Eliminate crevices, ledges, and protrusions in welded structures.

- Include lifting lugs on all assemblies.

- Ensure adequate clearance for equipment transfers.

The decontamination and decommissioning considerations for purchased equipment were incorporated into the procurement specifications.

Chapter 16 of the K Basins safety analysis report (DESH 1998) will be upgraded as required. No changes have been identified to date.

\section{REFERENCE}

DESH, 1998, K Basins Safety Analysis Report, WHC-SD-WM-SAR-062, Rev. 3D, DE\&S Hanford, Inc., for Fluor Daniel Hanford, Inc., Richland, Washington. 
HNF-2456, Rev. 0

This page intentionally left blank. 


\subsection{MANAGEMENT, ORGANIZATION, AND INSTITUTIONAL SAFETY PROVISIONS}

Cask loadout system (CLS) installation and installation acceptance testing will be performed under the management, organization, and institutional safety provisions described in the existing K Basins safety analysis report (DESH 1998). The program will be evaluated regarding CLS operation and will be addressed in the upgraded $\mathrm{K}$ Basins safety analysis report. No changes to accommodate the CLS have been identified to date.

\section{REFERENCE}

DESH, 1998, K Basins Safety Analysis Report, WHC-SD-WM-SAR-062, Rev. 3D, DE\&S Hanford, Inc., for Fluor Daniel Hanford, Inc., Richland, Washington. 
HNF-2456, Rev. 0

This page intentionally left blank. 


\section{DISTRIBUTION SHEET}

\begin{tabular}{|c|c|c|c|c|c|}
\hline \multirow{2}{*}{$\begin{array}{l}\text { To } \\
\text { Distribution }\end{array}$} & \multirow{2}{*}{\multicolumn{3}{|c|}{$\begin{array}{l}\text { From } \\
\text { Nuclear Safety }\end{array}$}} & \multicolumn{2}{|l|}{ Page 1 of 1} \\
\hline & & & & \multicolumn{2}{|l|}{ Date $3 / 10 / 99$} \\
\hline \multicolumn{4}{|l|}{ Project Title/Work Order } & \multicolumn{2}{|c|}{ EDT No. 624289} \\
\hline HNF-2456, Rev. 0 & & & & \multirow{2}{*}{\multicolumn{2}{|c|}{ ECN No. N/A }} \\
\hline \multicolumn{4}{|c|}{ Cask Loadout System Safety Analysis Document } & & \\
\hline Name & MSIN & $\begin{array}{c}\text { Text } \\
\text { With All } \\
\text { Attach. }\end{array}$ & Text Only & $\begin{array}{l}\text { Attach./ } \\
\text { Appendix } \\
\text { Only }\end{array}$ & $\begin{array}{c}\text { EDT/ECN } \\
\text { Only }\end{array}$ \\
\hline R. L. Besser & R3-26 & $\mathrm{X}$ & & & \\
\hline S. A. Brisbin & $\mathrm{R} 3-86$ & $\mathrm{X}$ & & & \\
\hline D. M. Chenault & $\mathrm{R} 3-86$ & $\mathrm{X}$ & & & \\
\hline W. A. Frier & $\mathrm{X} 3-76$ & $X$ & & & \\
\hline S. B. Harrington & R3-26 & $X$ & & & \\
\hline T. G. Hersum & A3-02 & $\mathrm{X}$ & & & \\
\hline M. J. Higuera & $\mathrm{S} 2-51$ & $X$ & & & \\
\hline V. L. Hoefer & $\mathrm{R} 3-86$ & $\mathrm{X}$ & & & \\
\hline H. L. Johnson & $\mathrm{X} 3-80$ & $\mathrm{X}$ & & & \\
\hline E. J. Krejci & A3-02 & $X$ & & & \\
\hline R. J. Kuhta & $X 3-76$ & $X$ & & & \\
\hline P. G. LeRoy & R3-I1 & $\mathrm{X}$ & & & \\
\hline J. D. Mathews & $\mathrm{R} 3-86$ & $\mathrm{X}$ & & & \\
\hline R. H. Meichle & $\mathrm{X} 3-79$ & $X$ & & & \\
\hline S. H. Peck & $\mathrm{X} 3-79$ & $\mathrm{X}$ & & & \\
\hline R. W. Rasmussen & $X 3-85$ & $X$ & & & \\
\hline J. L. Weamer (2) & $\mathrm{X} 3-85$ & $\mathrm{X}$ & & & \\
\hline R. L. Webb (5) & R3-26 & $\mathrm{X}$ & & & \\
\hline SNF Project Files & R3-11 & $X$ & & & \\
\hline
\end{tabular}

